PPS-3-001当科での胃 GIST 症例の検討

会立真志，余喜多史郎，山[1]哃史，兼田裕司，宮内隆行，矢田清吾 (德島県立三好病院外科)

緒言：当科で切除した胃 GIST8 症例を検討した．烸床検討：年柃 59〜 86 葴, 平均 70.8 藏. 男女比 $5: 3$. 部位 $\mathrm{U}$ 領域 6 例, $\mathrm{M}$ 領城 1 例, $\mathrm{L}$ 領城 1 例，壁内 3 例，壁外 5 例. 大きさ $0.5 \mathrm{~cm} \sim 30 \mathrm{~cm}$. 胃癌合併 4 例. CT 描出は 5 例で，造影で不均一な增強を示し，浸潤傾向なく，周囲への圧 排，䝑張性発育を示した．術前 GIST と診断しえたのは 2 例であった。 手術術式は全例開腹で, 胃涪合併例は胃切除, 非合併例は部分切除した。 予後は胃癌死亡 3 例, 他病死 1 例で, GIST 血行性転移例はなく, 再発死 亡例はない。病理組織学的検討：免疫組織化学的に全例 c-kit 染色陽性 に染まる腫的細胞を認めた．大きさ $5 \mathrm{~cm}$ 以上のもの，核分裂像 $10 / 50$ HPF 以上の悪性例（GIST研究会による）は 4 例であった，考察：胃 GIST は胃絽合併がなければ胃の機能が温存できる限り, 部分切除で充 分と考えられた．胃雷と GIST の合併が $50 \%$ に認められ，GIST が胃癌 と合併しやすい機序があるか今後検討する必要があると思われた。

PPS-3-002 胃 GIST 手術症例の臨床学的検討

坂口善久，島袋林春，椛島 章，小島康知，山村晋史，西崎隆， 松坂俊光

(松山赤十字病院外科)

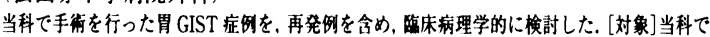
手街を范行し，病理学的にGIST と診断され，免疫組根学的に $\mathrm{c}$-kit 隄性であった 35 例を对

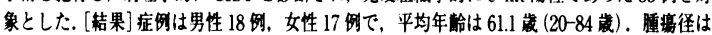
最大が $22 \mathrm{~cm}$. 平均 $6.6 \mathrm{~cm}$ で，壁外発育を示したしのが 13 例あった。手術術式任胃全揞術が

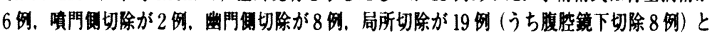

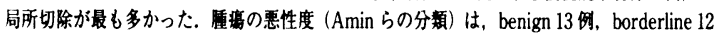

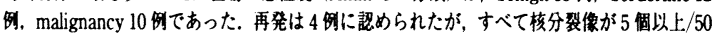

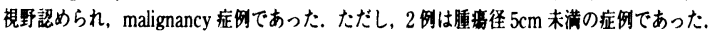

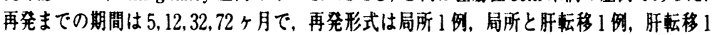

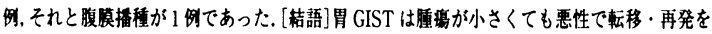

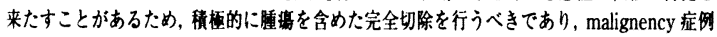
では再発を念須においた噛重かつ長期間にわたるフォローアッフが必要である。

\section{PPS-3-003 胃毒肉腫の一例}

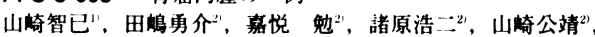

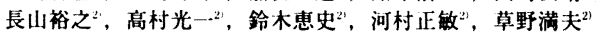

(昭和大学横浜市北部病院救急医学科"，昭和大学一般消化器外科 ${ }^{21}$ )

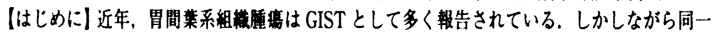

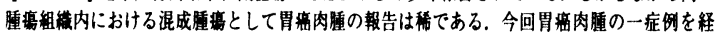

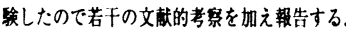

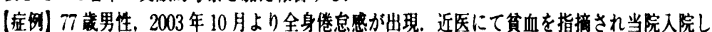

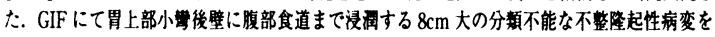

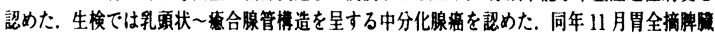

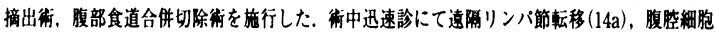

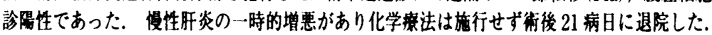
【病理】 p5T2 (SS) pN3pM1 (LYM) pCY1 stageIV であった。肉眼的には病变部口㥜は灰白

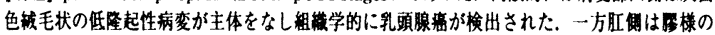

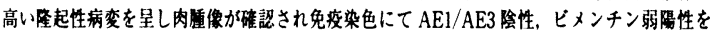

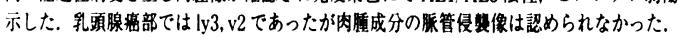

PPS-3-004 腫場内出血により急速に增大した胃 GIST の 1 例 吉川幸造, 尾方信也、木下貴史，恢藤宏彦，松山和男，柏木 豊， 長堀順二

(国立高知病院外科)

【目的】GIST では消化管内への出血は数多く報告されているが，睡㢈内への出血は報告が少

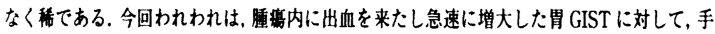

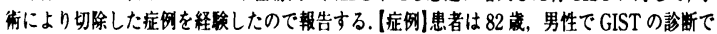

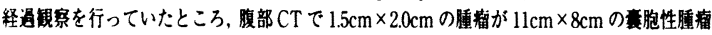

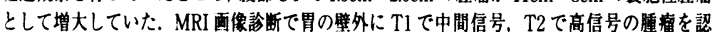
め。透视検榃でも噴門部に胃壁外より压排される所見を認めた。開腹所見では胃体上部後壁

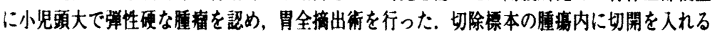

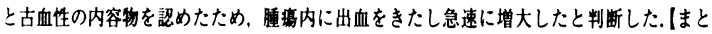

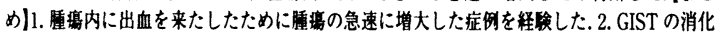

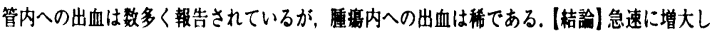

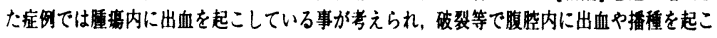
寸可能性が高いために，腹胵内に破裂する前に手巣を行う事が必要と考えられた。
PPS-3-005 胃静脈嘴を合併した胃 GIST の 1 例 松下啓二, 島田 良, 高山寛人，名取恵子，荻原廸彦 (豊科赤十字病院外科)

今回我々は，胃静脈瘤を合併した胃 GIST 症例を経験したので報告する，症例： 43 葴男性. 労作時の息切れを主訴に当院に受診した. 高度筫血があり上部消化 管内視鏡を施行し，胃体上部後壁に F1CwRC (+) の胃静脈嘴を認めた，腹部 CT は，胃を腹側正中に䐙，大腸を下方に圧排する $20 \times 18 \times 15 \mathrm{~cm}$ 大の内部が不

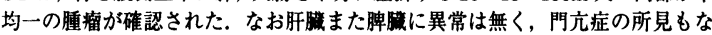
かった. MRIでは, 腫㾇は内部が不均一で T1 は low, T2 は high intensity を示

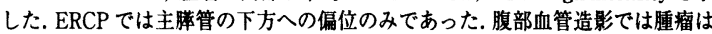
hypovascularであり, 静脈相で左胃静脈の拡張（静脈痛）を認めた，胃静脈瘦 を併発したGISTを疑い手術を施行した，腫嘴は小紧頭大で胃体上部後壁を基 部とした有茎性のもので, 壁外発育型の胃 GIST と診断し, その基部を含めて胃 部分切除を施行した，病理組穖診断では，CD34 (+), C-kit $(+)$ を示し, 胃 GIST と訩断された. 術後1 ケ月後の内視镜検査では胃静脈瘤は消失していた. 胃静脈嘴から出血した胃 GIST は報告例がなく貴重な症例と考えられた。

PPS-3-006 早期胃癌の直下に GIST を合併した 1 切除例 吉田尚弘, 村上 望, 伴登宏行, 森田克哉, 小泉博志, 吉野裕司, 藤森英希，俵矢香苗，中田浩一，山田哲司

(石川県立中央病院一般消化器外科)

(はじめに) 早期胃癌の直下に gastrointestinal stromal tumor（以下 GIST）を合併した秝 な 1 症例を経検したので報告する. [症例] 67 嵅, 男性. 平成 15 年 6 月下旬より上腹部蒲が 出現した。近医での上部消化管内視鏡検査にて早期胃癌が疑われ当科紹介受診となった。

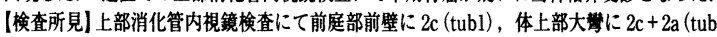

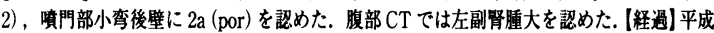
15 年 10 月 29 日, 手術施行, 術中生検にて左副紫腫大は過形成であったため胃全摘術施行 した. 【病理所見】 前庭部前壁に $1.8 \times 0.9 \mathrm{~cm}$ の 2a pap, pTl (M) を認めた. また，上部消

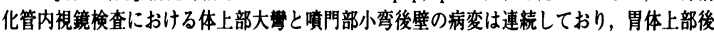
壁に $5.5 \times 2.1 \mathrm{~cm}$ の $2 \mathrm{~b}+2 \mathrm{c}$, tub2, por, pT1(SM2) として認め，さらにその直下に $1.3 \times 0.7$ $\mathrm{cm}$ の粘膜下腫場を認めた。免疫染色にて粘膜下腫場は GIST と診断された. [結語]早期胃 来と GIST の起源, 発生を考察するにあたり興味ある症例と思われた。また，烸床的には両

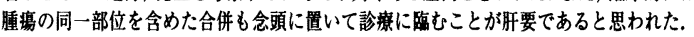

PPS-3-007 成年男子にみられた胃壁原発成熟奇形腫の一例 橋本拓也, 坪井光弘, 清家純一, 本田純子, 梅本淳, 門田康正 (徳島大学大学院病態制御外科)

成年男子において偶然発見された胃壁原発成熟奇形腫の一例を経験したので報告する。 【症例】 18 藏, 男性. H15 年 7 月, 腹有を訴之近医を受診. CT 検查を受けた際に左副腎 腫舫を指摘された，高血圧を認め血中及び尿中のアドレナリン, ノルアドレナリン值も 高值であったため褐色絧胞腄を疑われた. H15 年 9 月当院泌尿器科紹介. CT 再検查で

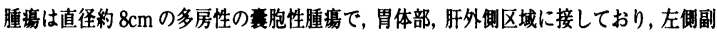
堅との境界は明暸で勝体部から発生していると考えられた. H15 年 12 月 10 日当科にて

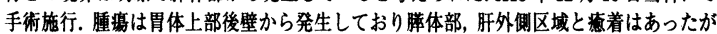

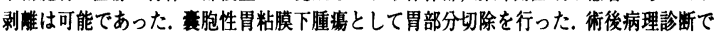

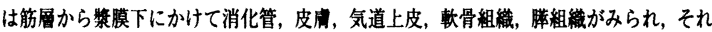
ぞれ樭胞を形成しており萲胞壁には平滑筋組織が豊富に認められた. Immatureな成分 はなく成熟奇形㣫であった。術後経過順罣で術後第 10 病日に飠院した. [考察]奇形腫は 小児期に発見されることがほとんどで, その内胃壁原発のものは $1 \%$ 末满であるとの報 告もある. 成人で発見されたものは本邦での報告も少なく非常に稀な症例であった。

PPS-3-008 胃の転移巣で発見された amelanotic melanoma の 1 例 鳥海久乃 ${ }^{1}$, 二村浩史 ${ }^{11}$, 篠原寿彦"，柏木秀幸 ${ }^{\prime \prime}$, 矢永勝彦 ${ }^{21}$ (東京慈恵会医科大学柏病院外科", 東京慈恵会医科大学外科 $\left.{ }^{2}\right)$ 【症例】 70 墄男性. 平成 15 年 9 月末頃, 心窩部痡出現. その後黒色便も認め られたため，近医受診。筫血を指摘されるも，原因不明であったため，精査 目的に 11 月 14 日当院紹介受診. 上部消化管内視鏡検査にて胃癌指摘され, 12 月 1 日手術目的に入院となった。既往歴は陳旧性肺結核, 高血圧症. 入院 時身体所見では，腹部は平坦，軟で自発痡，圧痛は認めなかった，肝脾触知 せず，腫㵔も触知しなかった。検査所見上, $\mathrm{Hb} 7.8 \mathrm{~g} / \mathrm{dl}$ と䝯血を認め, $\mathrm{ChE}$ $30011 \mathrm{U} / \mathrm{dl}, \quad$ TP $5.4 \mathrm{~g} / \mathrm{dl}, \quad$ Alb $3.3 \mathrm{~g} / \mathrm{dl}$ とやや栄養状態の低下を認めるのみで あった. CEA $8.3 \mathrm{ng} / \mathrm{ml}$ と腫場マーカーは軽度上昇を認めた。術前の腹部 CT 検査, 腹部超音波検査にて右副堅に腫境を認めた. 12 月 19 日手術施行. 術中 所見にて, 小晹にも2 2 所腫瘍を認めたため高分節胃切除術, 小晹部分切除 術, 右副督摘出術施行. 病理所見にて右副堅の amelanotic melanoma(AMM) の胃転移，小腸転移と訩断された.【考察】副腎原発の AMM は非常に稀な疾 患で，本症例で 3 例目と思われる. 文献的考察を加えて報告する. 
PPS-3-009 多発性胃カルチノイド 5 例の臨床病理学的特徵と外科的 治療に関する検討

岡田健一, 千野 修, 松山正浩, 岡本祐一, 山本壮一郎, 今泉俊秀, 生越香二, 幕内博康

(東海大学外科)

【目的】多発性胃カルチノイド 5 例の湢床病理学的特徽と外科的治㫫について検討し た. 【対象と方法】1977年から 2003 年までに教室で経験した多発性胃カルチノイドの 5 例を対象とした。男性 1 例女性 4 例で年龄は $42-62$ 歳, 平均 52.6 嵗 \pm 7.5 藏であっ た. 5 例とも外科的治療を施行した。【結果】いずれも無症状で健診等にて偶然発見さ れ, 内視鏡検查にて多発性胃カルチノイドと診断された。諸検査にて全例高ガストリ ン血症, 無酸症を示し, 術後 3 例にのみ血清ガストリン值が测定され, 著しい低下を 認めた.いずれも胃全摘術を施行し, 病理組織学的検查にてすべて A 型胃炎を伴った 多発性胃カルチノイド(Rindi らの分類における Typel の胃カルチノイド)であった. いずれも術後補助治燎なく無再発生存中である(4-144ヶ月, 中央值 108.4 ケ). (結 論最近の同疾患，その発症病態に関する新しい知見や概念の変㟟を考慮すると, 術 後消化機能を温存する術式も術式選択の際検討すべきであると考えられた。

PPS-3-010 A 型胃炎に発生した胃カルチノイドに対し腹腔鏡下胃局 所切除を施行した 1 例

湯汲俊悟, 渡部祐司, 堀内 淳, 鈴木秀明, 吉川浩之, 佐藤公一, 松野裕介, 河内宽治

(愛媛大学第 2 外科)

【症例】 41 才男性. 検診にて胃体中部小数に隆起性病変を指摘された，当院内科にて胃 内梘鏡検查を施行され，胃体中部小䇣前壁に径 $8 \mathrm{~mm}$ 大の Isp ポリーブを指摘された. 胃 体部小举前壁より幽門前庭に功て萎綰性変化も伴っていた. 生検にて carcinoid tumor と診断された。 また, 血清ガストリン $3019 \mathrm{pg} / \mathrm{ml}$ と高值, 抗内因子抗体淂性であった。 以上より A 型胃炎に発生した胃カルチノイド(typel)と診断され，EMRを施行された。 病理組織学的换討にて carcinoid tumor と診断さたれが, 深部断端陽性にて当科紹介され た. 術前に EMR 後の部位を止血用クリップにてマーキンクし, 腹胫鏡下に leision-lifting 法にて胃局所切除を施行した. 術後経過は良好であった. 病理組織検查にて標本中に僅か に carcinoid tumor の增殖巣が残存しており, sml, ly0, v0, surgical margin free であっ た【はとめ】 A 型胃炎に発生した胃カルチノイドは生物学的悪性度が低く，過利な侵意 を避ける意味では lesion-liftingによる腹腔鏡下胃局所切除はよい適応であった。

PPS-3-011 多発胃カルチノイドに対するソマチスタチンレセプター シンチを用いた術中局在診断

細谷好則 ${ }^{1)}$ ，永井秀雄 ${ }^{1)}$ ，佐藤貴一"2)，菅野健太郎 ${ }^{2)}$ ，弘中 貢 ${ }^{32}$

(自治医科大学消化器・一般外科 ${ }^{1)}$, 消化器内科 ${ }^{2}$, 病理 ${ }^{3}$ )

症例は 30 歳男性. 胃体上部に $30 \mathrm{x} 25 \mathrm{~mm}$, 体下部に $20 \mathrm{~mm}$ の発赤を伴う有茎性のカルチノイト

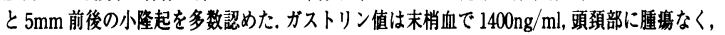
末血 MEN-1 遗伝子 LOH なし. Updated Sydney System の 4 点生検からは型的 A 型胃炎 の所見なく，改少ガストリノーマの可能性があった，ソマトスタチンレセフターシシチ (Octreo Scan)を用いて術中に微小ガストリノーマの存在の有無, およびカルチノイド局在診断を 行った. 胃腫棉に一致して100-130 のレンジでカルチノイドを指摘でき，ガストリノーマの存 在は否定できた、リンパ節郭清を伴う胃全摘術を梅行し，ガストリン值は正常箅围内に低下し

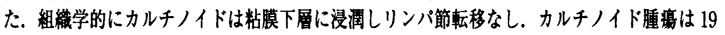
病変, $0.5 \mathrm{~mm}$ 以下の endocrine cell micronest を多数認めた。前庭部ではガストリン晹性緗胞 が增加していた. 胃体部は A 型胃炎の初期像と考えられる壁綝胞の通形成 (parietal cell ppseudohypertrophy : Torbenson M. et al. Mod Pathol. 2002；15）であった. 非常に稀な病態 であったが，Octreo scanを用いた術中ナビゲーション手術は局在診断に有効であった。

PPS-3-012 A 型胃炎に発生した多発性胃カルチノイドに腹腔鏡手術 を施行した 1 例

平尾隆文, 瀧口修司, 安座間隆, 宮田博志, 藤原義之, 安田卓司, 矢野雅彦, 門田守人

(大阪大学大学院病態制御外科)

多発性胃カルチノイドに対して，腹佶鏡手術が有効であった症例を経験したので報告す る. 症例は 47 葴の女性. 上部消化管内梘鏡検查で胃体部全域とU 領域に散在した数 $\mathrm{mm}$ 大の小隆起性病変を認め, 生検の結果から多発性胃カルチノイドと診断された。血中ガス トリンは $3200 \mathrm{pg} / \mathrm{ml}$ と著しい高值を示し, 抗胃壁抗体陽性で A 型胃炎に発生した胃力

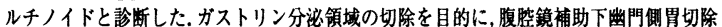
ならびにU 領域のカルチノイドに対し，胃内粘膜切除術を施行した。術後14 日目に血清 ガストリンは正常化した．また残胃に残存していた径 1 2mm の小隆起性病変は術後 100 日目の内視鏡検查で, 霞痕を認めるのみで生検で, endocrine cell およびカルチノイ ドの消失を確認した，近年，A型胃炎に発生した多発性胃カルチノイドの治㞠として幽

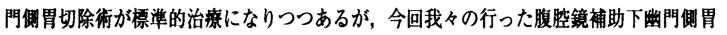
切除ならびに胃内粘膜切除術は，低侵襲性であり有用性が高いと思われた。
PPS-3-013 胃原発神経内分泌細胞㾔 (neuroendocrine cell carcinoma）の一例 中村 威"，金井藏雄"，高林 司"，中川基人"，坂田道生"， 松本圭五", 龟山香織" (平塚市民病院外科"，慶應義势大学病理 ${ }^{2}$ )

胃原発の neuroendocrine cell carcinoma は比教的稀であり，極めて予後不良である。

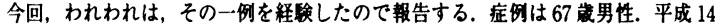
年 12 月より上腹部蔽が出現, 平成 15 年 2 月に精査加竟目的に当院紹介受診となる. 胃体上部後壁に約 5 センチ大の 1 型腫茠を認め, 生検材料の病理訩断は gruopV, 低 分化型腺者であった．同年 4 月 10 日胃整 (U Less cTypel cT2N1HOM0 cStageII)の

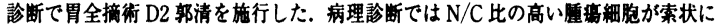

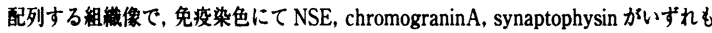
陽性であり, neuroendocrine cell carcinoma と診断された, 肺などの全身検索では他 に明らかな異常所見は訆めず, 胃原発の neuroendocrine cell carcinoma と訜断した. 街後 5 ケ月に肝転移を認め，低容量 5-FU/CDDPを 4 週間投与したところ PRを得 たため，再度低容量 5-FU/CDDPを 4 週間追加投与し，経通铸察中である。

PPS-3-014 Paclitaxel 投与が有効であった多発肝転移を伴う胃内分 泌細胞瘦の 1 例

永瀨剛司, 沖代格次, 荒能義彦, 佐々木正寿

(済生会高岡病院外科)

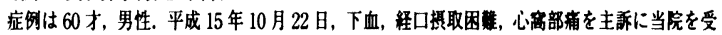

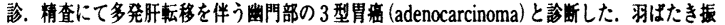

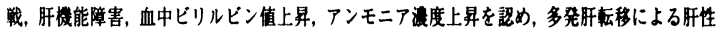

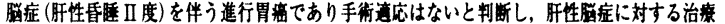

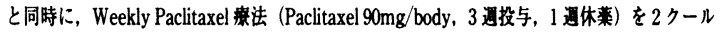

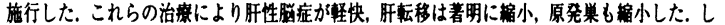

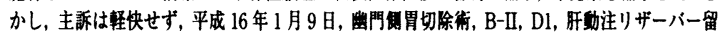

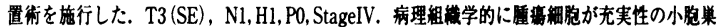

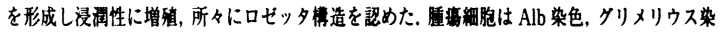

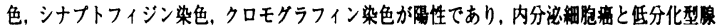

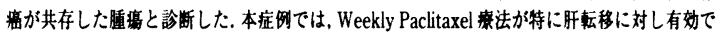

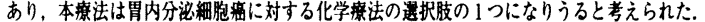

PPS-3-015 腹腔細胞診陽性であった早期胃内分泌細胞癌の 1 例 宇野浩司, 木田孝志, 大越祐一

(滝宮総合病院外科)

胃内分泌練胞䍃は比較的まれで，予後不良な疾患である. 今回われわれは術中 腹腔細胞診が陽性であった早期胃内分泌細胞㾇を経溆したので報告する，症例 は79歳の男性で，主訴は上腹部蒲であった，胃体下部前壁にIc 病変を認め, 生検では中分化型腺瘦であった，CT 検査では逴隔転移を認めなかったか，小弯 リンパ節の腫大を認めた。幽門側胃切除術, D2, Roux-Y 再建を施行した，術中

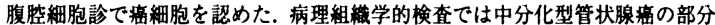
と充実性の增殖と roset formation を示す部分が見られ，後者の部分では chro mogranin A 陽性, synaptofizin 陽性, Grimelius 陰性であり，腺㾔が混在してい

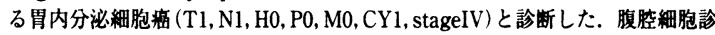
陽性は転移りンパ節の蹈細胞が被膜外に漫洞し，腹胿に散布されたものと考え られた，家族の希望により化学撩法は行わなかった。術後 3 か月の現在再発を 認めていない. 胃内分泌細胞潘は本症例のように原発部が早期に発見されても 転移していることが多く，有効な化学燎法の確立が望まれる。

PPS-3-016 食道癌術後の早期再建胃管㿋に対し, 開胸下局所切除を 施行した一例

吉田 晋"，金子 聡"，岩城堅太郎"，吉永敬士"，大田隆司"，

甲斐哲司"，穴井秀明"，野田尚-1"，上尾裕昭"

(国立大分病院外科"，上尾乳腺外科"2)

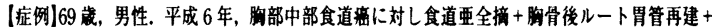
新部吻合を施行. 中分化型扁平上皮患, 深達度 a3, pN2, StageIV. その後再発はなかった. 8 年 3 力月後の平成 15 年 3 月，定期検查の上部消化管内梘鏡模査で，預部㽖合部より約 $2 \mathrm{~cm}$

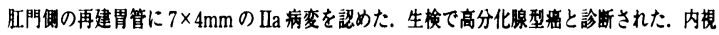

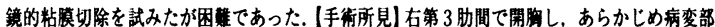

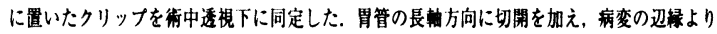
$10 \mathrm{~mm}$ ほどの margin をとり胃管局所切除をした，切除後は 3-0吸收系で短方向に全層一

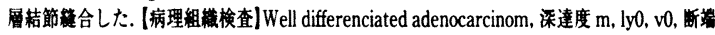

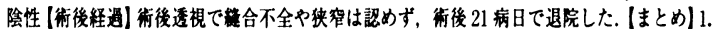

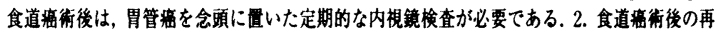
建胃管癌に対して，症例によっては胃管局所切除も㟟択肢になり得ると思われた。 
PPS-3-017 增殖・漫潤能の異なる Mongolian Gerbil 腺癌細胞株 2 株 の樹立とその細胞学的特性の解析

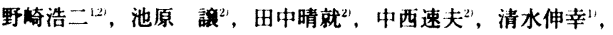
真船健一"

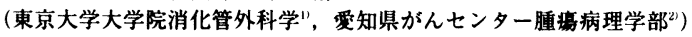

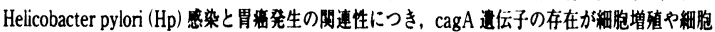

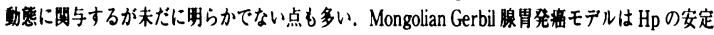

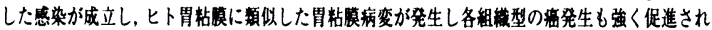

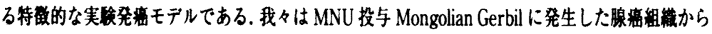

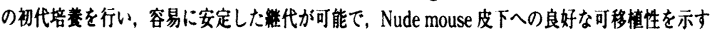

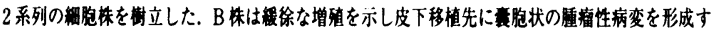

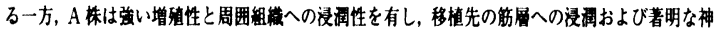

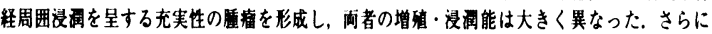

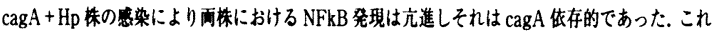

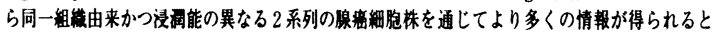

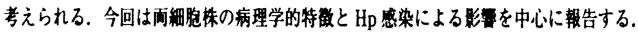

PPS-3-018 胃瘦手術後の MRSA 感染症例の検討-周術期因子と抗生 用の投与をめぐって

長谷川博一"，江上 格"，笹島耕“”，渡透裕"，宮本昌之"，

丸山弘"，鈴木成治"，横山正"，前田昭太郎”，田肩 孝"

(日本医科大学多糜永山病院外科"，日本医科大学多糜永山病院病理"，日 本医科大学第 1 外科 ${ }^{3}$ )

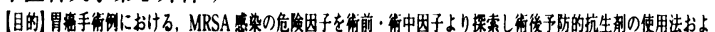

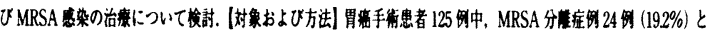

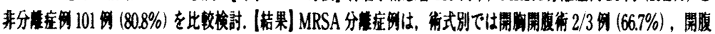

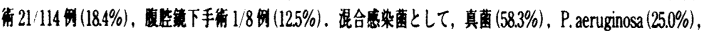

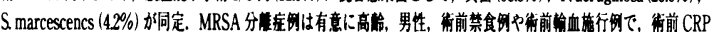

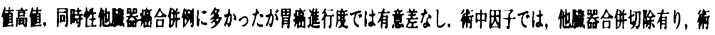

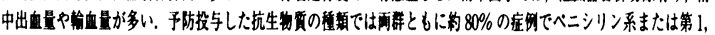

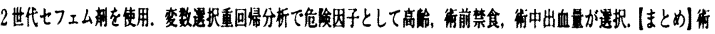

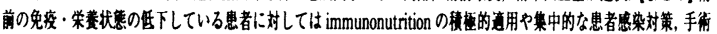

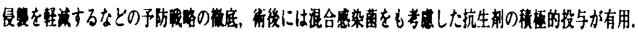

PPS-3-019 幽門側胃切除術における予防的抗生物質投与法の検討

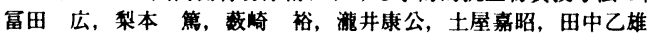
(新潟県立がんセンター新鼬病院外科)

当科では胃癌に対する幽門㑡胃切除術(幽切)のクリティカルパス (CP)を 1999 年 10 月に導人したが，予防的抗生物質投与法には時代的な変㩧があった. 今回 は CEZ1 日投与法の要当性について乎術部位感染 (SSI) を中心に検討した. I対 象・方法了2001 年 1 月から 10 月までの幽切 109 例を術後FMOX4 日投与群 (A 群)，2001 年 10 月から 2002 年 10 月までの 137 例を FMOX1 日投与群(B 群), 2003 年 4 月から 10 月までの 102 例を CEZ1 日投与群 (C 群) とした. 3 群の術 後合併症およびSSI 発生状況を比較, 検討した（結果) 1. 術後合併症発生率は A 群 $21.1 \%, B$ 群 $19.0 \%, C$ 群 $17.6 \%$ と差はなかった. 2. 術後 SSI 発生率は A 群 9 例， $8.3 \% ， \mathrm{~B}$ 群 16 例，11.7\%，C群 11 例，10.8\% と差はなかった。 C 群の SSI 発生症例に重症感染症例はなく, 術後入院日数に全く差は認められなかっ た(術後平均入院日数は $\mathrm{A}: \mathrm{B}: \mathrm{C}=13: 12: 12)$. (結㖣]幽切において予防的抗 生物質投与は CEZ 手術当日のみの投与で特に問題は無く, その後発症した感染 症に对しては通正な抗生物犋を投与することにより对応可能であった。

PPS-3-020 重症 AIDS 患者に対する胃癌手術の経験

高山卓也, 別宮好文, 小西寿一郎, 田原秀晃

(東京大学医科研先端医療研究センター外科)

カリニ肺炎の治㾦中に指摘された進行胃竞に外科的切除を行ない，特異な術後経通を 経输したので報告する. [症例] 54 才男性. 重症 AIDSに伴ったカリ二肺炎の治療中に

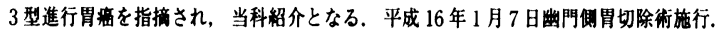

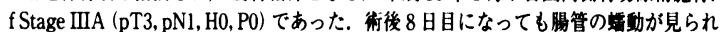
ず，麻庫性イレウスを発症したためイレウス管を留篔した。 また 12 日目には顆粒球娍 少症をきたし，G-CSF 製郕の投与により軽快した，その後は経通良好にて術後21 日目 に内科転科となった［考察】一般に, HIV 淂性患者の外科的切除は CD4 隄性 T緗胞が $500 / \mathrm{mm}^{3}$ 以上あれは手術亶応に制限はないとされているが, $200 / \mathrm{mm}^{3}$ 以下の場合は小

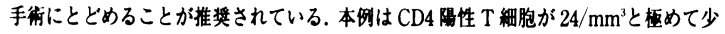
なかったが, 高度の幽門㹨窄のために手術に踏み切った，本例では幸いこれらの合併症

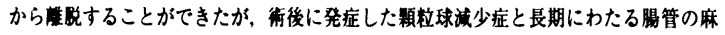
费の原因は未だ不明であり，報告も見当たらない。(結部]重症 AIDS患者の胃切除後に

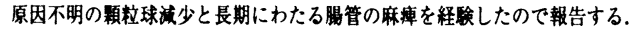

PPS-3-021 ビーグル犬に対する 13C 呼気試験法胃排出能検查の検討 道浦 拓, 中根恭司, 中井宏治, 井上健太郎, 佐藤睦哉, 山道啓吾, 上山泰男

(関西医科大学外科)

(目的) gastrointestinal motility のモデルとして類䋈に使用されるビークル犬に対し， $13 \mathrm{C}$ 呼気試呀法胃排出能検查が施行可能かどうかを検討する. (対象と方法) 対象は健常 ビータル犬 5 匹とした。試联前の呼気採集後,試験食を投与し各ポイントで呼気を採集 し UBiT IR300を用い測定し，測定結果から Ghoosらの方程式にならい各パラメーター (Tmax T1/2 GEC)を算出した。試験食は液体 (ラコール $200 \mathrm{ml}+13 \mathrm{C}-$ Acetate $50 \mathrm{mg}$ ), 固体（ドッグフード 200kcal+卵黄に 13C-Octanoic acid50mg を混入したスクランフル

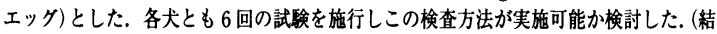
果) $13 \mathrm{CO} 2$ excretion curve は測定值と理論值の間で相関した. 各パラメーターとその Coefficient of variation (\%) は, 液体では $\mathrm{Tmax} 0.75 \pm 0.08(\mathrm{~h}), \mathrm{T} 1 / 21.16 \pm 0.17(\mathrm{~h})$, GEC $5.16 \pm 0.52$ で CVは $10.7 \%, 14.0 \%, 10.1 \%$ であった. 固形 $\mathrm{T} \max 1.78 \pm 0.30(\mathrm{~h})$ $\mathrm{Tl} / 22.63 \pm 0.54$ (h), GEC $3.35 \pm 0.49$ で CV は 17.1\%, 20.0\%, 14.7\% であった. (まとめ) $13 \mathrm{C}$ 呼気試験法胃排出能検查は非侵變的な胃排出試験として使用可能と思われた。

PPS-3-022 ヘリコバクターピロリを含めた残胃癌の臨床病理学的検 討 重田英隆, 長嶋孝昌, 水上泰延, 平松和洋, 長谷川雅彦, 松下晃三, 新美清章 （遠州総合病院）

く目的>ヘリコバクターピロリ感染 (以下 HP) を含めた残胃㢖の臨床病理学的因子を検討し, その危険因子を特定することく方法>1985 年 8 月より 2003 年 12 月までに手術をうけた残胃 癌患者 18 人を検款した. 対照として2001 年 5 月より 2003 年 9 月までに胃切除術後内梘鏡検査 をうけた残胃需のない 30 人 (残胃群) も検討した，〈桔果〉初回手術から残胃整発生までの期 間は初回良性群では初回悪性群に比べ有意に長期間であった。 また残胃繰群では残胃群と比べ B-2 症例が有意に多く $(\mathrm{p}<0.0001)$ ，有意に女性が多かった $(\mathrm{p}<0.05)$ ．逆にHP感染率は有意 に低かった $(\mathrm{p}<0.05)$. 胃要胃切除術後の残胃㿋群と残胃群を比べると, 残胃㿋群に有意に初回

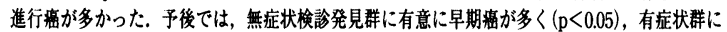
比べ有意に予後が良好であった $(\mathrm{p}<0.05)$. 〈桔語 >1. 幽門側胃切除術後では初回悪性群, 進行

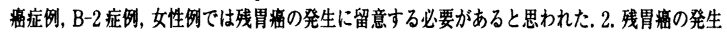
にHPの関与は少ないと考えられた３. 無症状検診発見群の予後は有意に良好であった。

PPS-3-023 穿孔性胃㿋 5 例の検討

中村陽一, 長尾二郎, 斉田芳久, 高瀬 真, 奥村千登里, 中村 萓, 片桐美和, 草地信也, 渡㟟 学, 炭山嘉伸

(東邦大学第 3 外科)

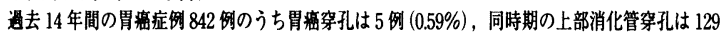

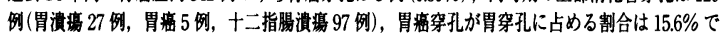
あった. 男: 女 $=3: 2$, 平均年橉 67.8 歳 (59 74 歳). 1 例は穿孔に対して大網充填術を施行し その後の内視鏡検査にて胃乘と判明した. 3 例は胃癌の訩断で精査中に, 1 例は切除不能胃癌化

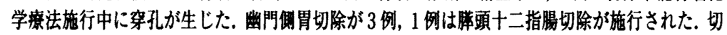
除不能胃㿋の 1 例は保存的に穿孔部が閉鎖した。肉眼型は 2 型, 4 型, 5 型が各 1 例, 3 型が 2 例であった，組紻型は tublが 2 例, por が 2 例であった。深達度はSSが 2 例, SEが 2 例, SI が1例. リンハ節転移は $\mathrm{N} 1$ が 3 例, N2が1例, N3が1例. 予後不良で 3 年の生存を得られた ものは無かった. 胃穿孔例においては胃癌穿孔の割合が比僌的高く, 胃穿孔の際には雷による穿 孔も念頭に置く必要がある. 胃癌穿孔の治㞠では腹膜炎に対する治療による救命が最優先され るが, 凊に対して治慜切除が可能ならば全身状態の許す限り根治術を行うべきである. 末期胃癌

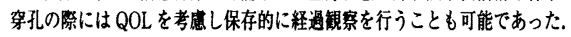

PPS-3-024 胃癌穿孔の治療方針について

井上 暁, 田中荘一, 真栄城剛, 宮本幸雄, 松尾 聰, 梅北信孝, 北村正次

(東京都立黙東病院外科)

[目的】胃密穿孔に拉ける暗切な治療方針を検討した. [方法】自験 26 例を対象. 平均 62.7 歳. (成絰]1) 癌診断の時期 術前 8 例, 術中 9 例, 保存的治療後 3 例, 単純閉鎖術後 3 例. 切除後永久標本 3 例. 2) Stagel $: 2: 3: 4$ はそれぞれ $4: 1: 5: 16$ 例. 3) 術式 幽 門側胃切除 8 例, 胃全摘 6 例, 単純閉鎖術後二期的切除: 3 例, 保存的治療後切除: 2 例, 単純閉鎖のみ: 5 例, バイパス $: 3$ 例. D0 $: 3, \mathrm{D} 1: 7, \mathrm{D} 2: 9$. 根治度 $\mathrm{A}: 2, \mathrm{~B}: 9, \mathrm{C}:$ 8. 直接死亡例なし. 4) 予後 根治度 Aの 2 例は 12 年以上生存中. 根治度 B の 3,5 生率 は $38 \%, 25 \%$. 根治度 Cの 2 年生存率は $25 \%$, 非切除例の平均生存期間は 78 日. 5) 根 治度 $\mathrm{B}$ 死亡例の再発形式 腹膜 2 , 肝 3 , リンパ節 2 (重複あり). (結論】胃潘穿孔は予後良 好な早期鹳穿孔と, 多数の予後不良な高度進行癌とに分かれるが, その中間に位置する進 行緲においては根治度の向上が予後改善に重要で, 術中の癌診断が不確定な場合は単純 閉鎖衍後に根治的切除を施行するのがよいと思われる. 根治度 C 症例の切除の意義は明 らかではないが, 現時点では可能ならば切除した方が延命に寄与しうると思われた。 
PPS-3-025 残胃癌手術症例 20 例の検討

金光望哲, 川崎健太郎, 神垣 隆, 大野伯和, 市原隆夫, 生田啓, 黒田嘉和

(神戸大学消化器外科)

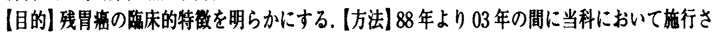

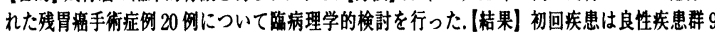
侧 (良性群)，悪性疾患群（悪性群）11 湖であり，残胃瘁手術までの平均期間は良性群は 25.1 年と悪性群の 8.4 年と比して期間が長かった。初回手術時の再建方法は Billrothl (B1) が7 侧, Billroth2（B2）が 13 湖であった. 残胃要手術までの平均期間は B1 群は 8.9 年と B2 群の 20.3 年と比して期間が短かかった. Stage は 4 が 9 例 $(45 \%)$ と多く，侵達度は se 以上が 11 例 $(55 \%)$

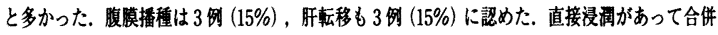
切除されたのは 4 例であった。二年生存率は良性群，黑性样と有意差はなく，再建方法ではB

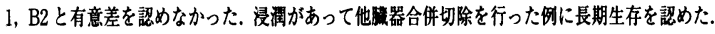

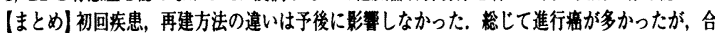

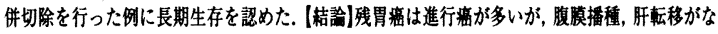
い症例では合併切除を行う事により長期生存を得られる可能性が示睃された。

\section{PPS-3-026 当院における残胃癌の検討}

毛利智美, 加藤俊夫, 伊藤佳之, 成田公昌, 入山拓平

(同心会遠山病院外科)

当院において 1989 年 1 月から 2003 年 12 月までの間に経験した残胃癌手術症 例 19 例につき検討した. 初回良性群（以下 B 群) 6 例と初回悪性群 13 例（以 下 $\mathrm{M}$ 群) に分けて検討した. 平均年令は B 群 67.8 歳, M 群 64.6 藏であった. 初回手術時の再建方法は B 群では BillrothI 法再建 4 例, BillrothII 法再建 2 例 であった. M 群では BillrothI 法再建 12 例，嗔門側胃切除 1 例であった. M 群の初回手術時の進行度は早期癌 6 例, 進行癌 7 例であった。 介在期間は $\mathrm{B}$ 群では平均 30.2 年, $\mathrm{M}$ 群では平均 3.92 年であり, $\mathrm{M}$ 群で有意に短かった。 発生 部位は $\mathrm{B}$ 群では非断端部 1 例, 吻合部 5 例, $\mathrm{M}$ 群では非断端部 10 例, 吻合部 1 例, 残胃全体 2 例であった. 残胃癌の進行度は B 群では早期㾔 1 例, 進行瘭 5 例であった. M 群では早期䆛 4 例，進行瘘 9 例（残胃再発例 5 例を含む）て あった. 組織型は B 群では分化型 4 例, 未分化型 2 例であった. M 群では分化 型 8 例，末分化型 5 例であった。両群とも分化型䅜が多い傾向がみられた。リ ンバ節転移は B 群では 1 例に陽性であった．M群では 8 例で陽性であった。

PPS-3-027 残胃の癌の臨床病理と治療-58 例の検討から川島吉之 ${ }^{11}$, 田中洋一", 竹下勇太郎 ${ }^{12}$, 戸塚 統", , 山田達也", 小林照忠"，網倉克己"，西村洋治"，坂本裕彦"，黒住昌史 ${ }^{2}$ (埼玉県立がんセンター腹部外科" ${ }^{1}$, 埼玉県立がんセンター病理科 $\left.{ }^{2}\right)$

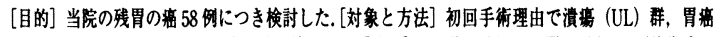

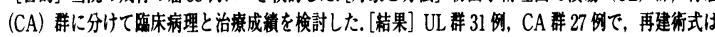

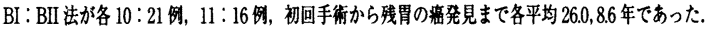

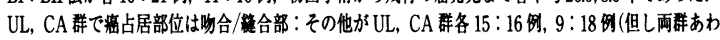

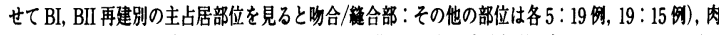

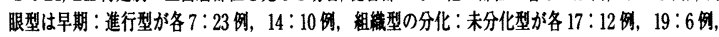
深達度は T1：T2：T3：T4：不明が各 $4: 8: 8: 7: 4$ 何, $14: 2: 0: 8: 3$ 体であった。外科切除が 各 26,18 例，非切除が各 3,3 何，EMRが各2,6例に施行された。外科切除成绩は UL, CA 群で 5

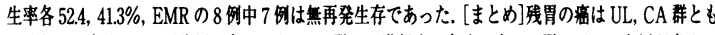

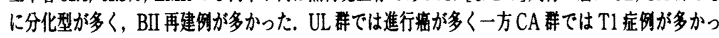

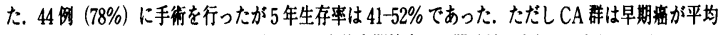
5 6年で発見され，6例にEMRが行われ，術後定期唡査が早期発見に奇与したと思われた。

\section{PPS-3-028 初回再建術式からみた残胃の癌の特徵}

永岡 栄, 板東隆文, 磯山徹, 遠藤健, 喜島健雄, 酒井敬介, 丸山嘉一, 野地 満, 豊島 明, 高山尚久

（日本赤十字社医療センター外科）

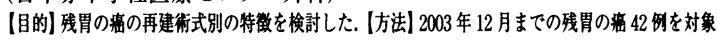

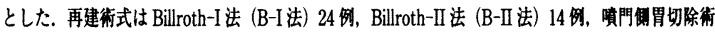

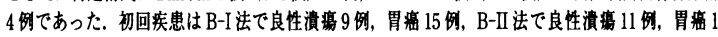

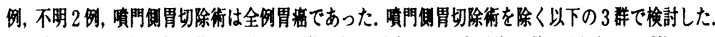
初回良性で B-I法再建の群 9 例 (B1-B 群), 初回胃悉で B-I法再建の群 15 例 (B1-M 群), B-II

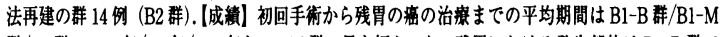
群/B2 群で 20.1 年/ 8.6 年/31.8年と B1-M 群で最も短かった。残胃における発生部位は B1-B 群で

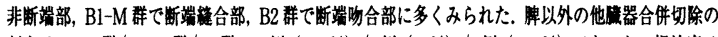

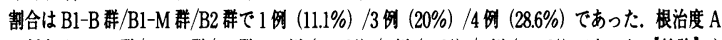

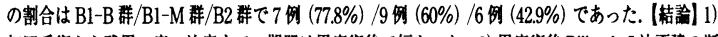

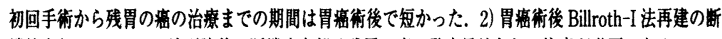

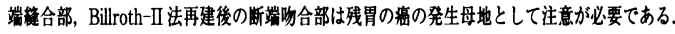

PPS-3-029 食道浸潤胃癌に对する開胸開腹下胃切除症例の検討 森島宏隆, 根津理一郎, 藤川正博, 藤井美, 前田庄平, 甲斐康之, 仲 至永, 武本智㴻, 山上裕子, 宮菩安晃

(大阪労災病院外科)

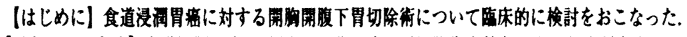

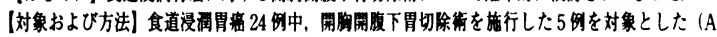

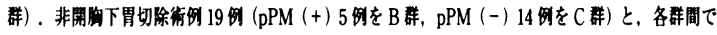
の 1 年生存害, 1 年繁再発生存事を比鞂模討した。

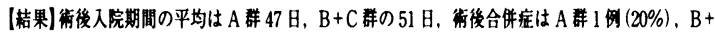

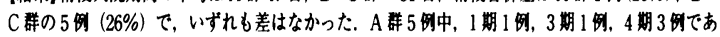

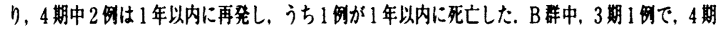

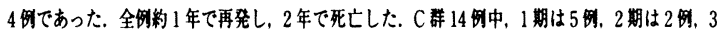

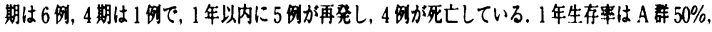

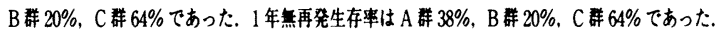

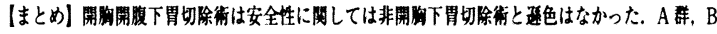
群とも，進行した症甽か多く，生存害に差はなかった。

PPS-3-030 粘液組織学的検討が食道由来腺癌の籍別に有用であった 食道胃接合部胃癌の一例

斎藤良太 ${ }^{\prime \prime}$ ，高橋直人"，佐野芳史"，三森教雄"，柏木秀幸"， 矢永勝彦

(東京惒恵会医科大学外科"，東京慈恵会医科大学柏病院外科 ${ }^{21}$ )

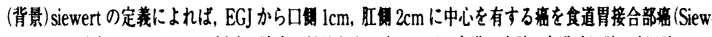

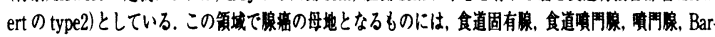

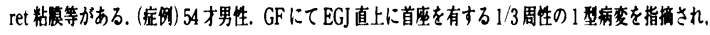

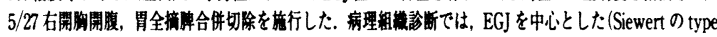

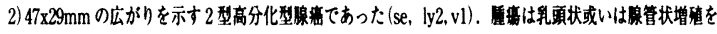

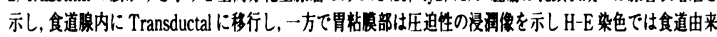

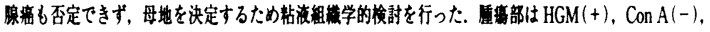

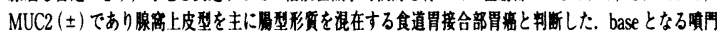

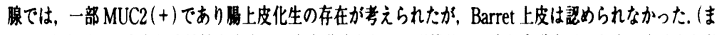

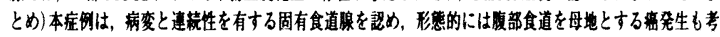

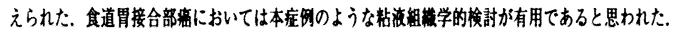

PPS-3-031食道漫潤胃者に対する開胸手術の適応と予後 中村公紀, 岩满 諴, 中谷佳弘, 中 禎二, 石田興一郎, 上田健太郎, 榴田佳紀, 尾島敏康, 中森幹人, 山上裕機 (和歌山県立医科大学第 2 外科)

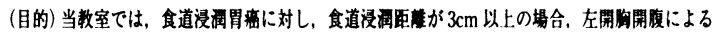

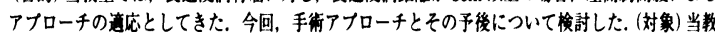

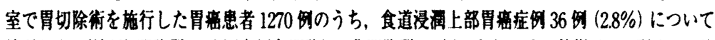

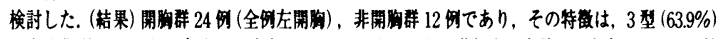

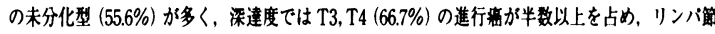

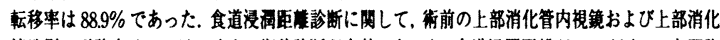

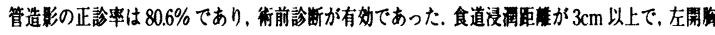

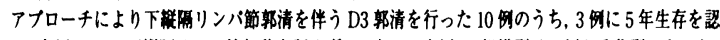

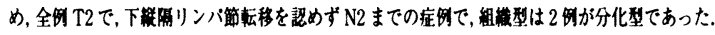

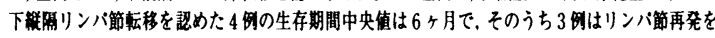

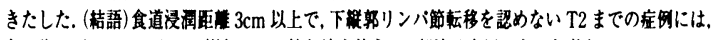

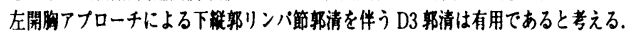

PPS-3-032高度食道漫润嗔門部盘に対する化学撩法併用放射線㙩法 により根治切除可能となった一例

高橋正統, 高金明典, 阿部 櫓, 中屋 勉, 米澤仁志, 大山健一,

藤原久貴, 斉藤和好

(岩手医科大学第一外科)

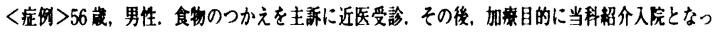

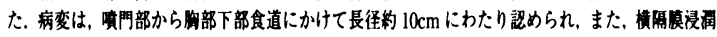

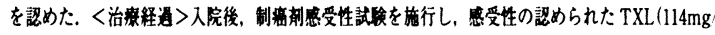

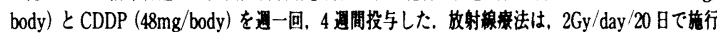

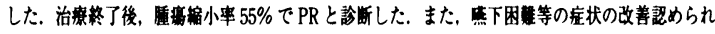

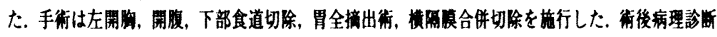

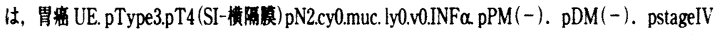

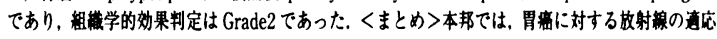

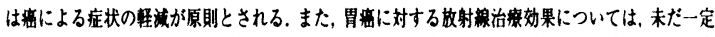

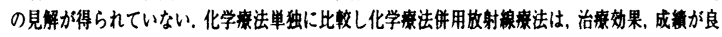
好との報告もあり，今後さらに検討されるべき治啬法のひとつと思われる． 
PPS-3-033 十二指腸乳頭部㾇手術症例の烸床病理学的検討 志波友佳子，梅北信孝，真栄城㓝，吉田 操, 北村正次 (東京都立墨東病院外科)

【目的】十二指晹釈頭部癌術後症例の成綨と組織学的因子との関係から予後 影策因子を検討した.【方法】過去 16 年間に当院で切除術を施行した乳頭部 癌 30 例中 5 力月以上の経過钼察例 30 例を対象とした. 男性 19 例, 女性 11

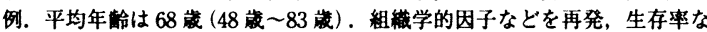
どと比較検討した．生存毫には Logrank 検定を用いた。結果】 stage 別 5 生乎は $1-86 \%, 2-60 \%, 3-47 \%, 4 a-33 \%$ ，再発は 11 例，内訳は肝転移 6 例, 腹膜播種 4 例, 局所再発 1 例であった. Stagel でも肝転移が 1 例あった. 組織学的因子別に 5 生事を検討した. $\mathrm{N}$ に関しては, 0-73\% (21 例), 1-100\% (2 例)，2-0\% (5 例)，3-0\% (2 例)．組織型別では，乳頭腺癌-60\%（5 例)，高分化型管状腺痹-82\% (14 例)，中分化型管状腺癌-33\% (6 例)，低

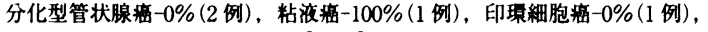

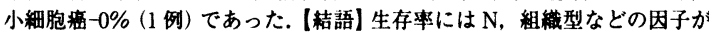
関連する. 特に $\mathrm{n} 2,3$ 症例では全例再発し, 予後不良因子と考えられる.

PPS-3-034原発性十二指晹癌 8 例の隍床病理学的検討

尾上俊介, 加藤岳人, 鈴木正臣, 柴田佳久, 尾上重已, 長澤圭一, 吉原 基, 小西由樹子, 渡䢖次, 新田英利

(豊橋市民病院外科)

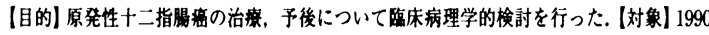

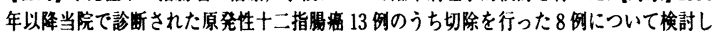

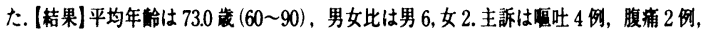

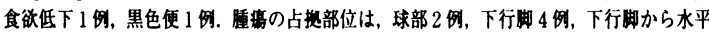

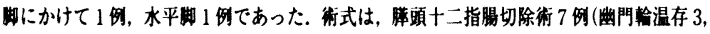

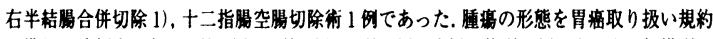

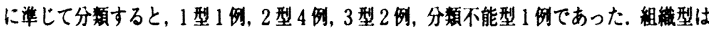

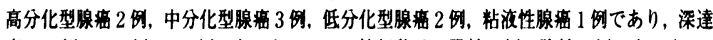

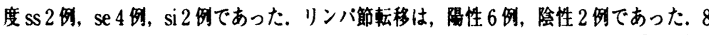

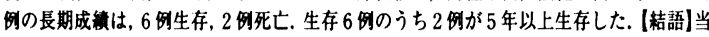

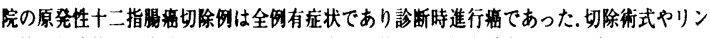

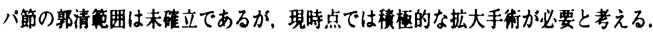

\section{PPS-3-035 当科における十二指晹乳頭部癌症例の予後及び再発例の} 検討

佐藤就厚, 舟木 洋, 経田 淳, 津山 博, 野島直已, 福島 亘, 角谷直孝, 廣澤久史, 泉 良平

(富山市民病院外科)

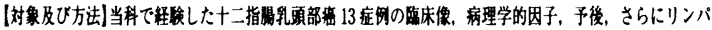

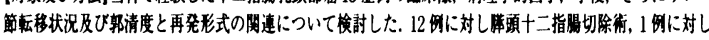

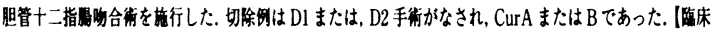

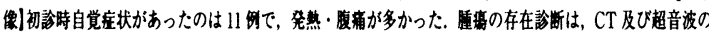

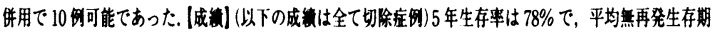

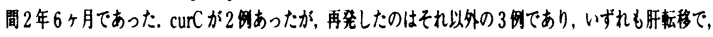

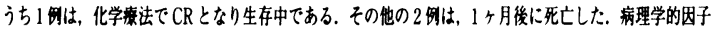

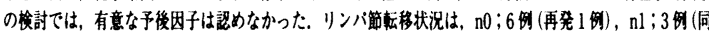

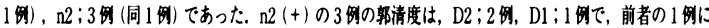

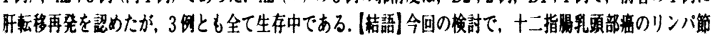

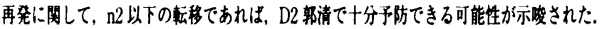

PPS-3-036 経過钼察中に外科的治療が必要となった原発性早期十二 指腸瘭の 2 例

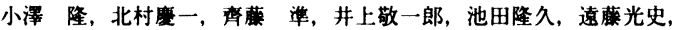
土田明彦, 青木達哉

(東京医科大学第 3 外科)

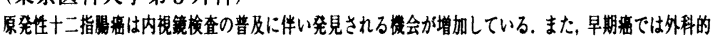

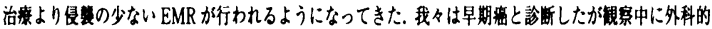

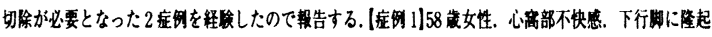

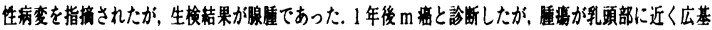

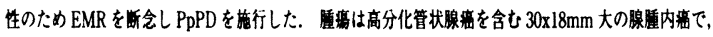

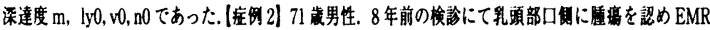

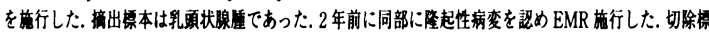

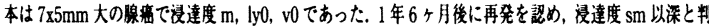

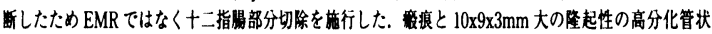

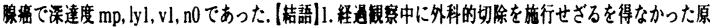

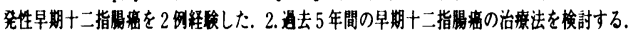

PPS-3-037 十二指腸原発腺扁平上皮癌と胃癌の同時性重複癌の 1 切 除例

北鄉 実"，小野滋司 ", 前田真悟"，栗原博明"，田村 光"，

小島正夫", 斉藤 建 ${ }^{2}$

(芳賀赤十字病院外科 ${ }^{1}$, 自治医科大学病理 ${ }^{2}$ )

われわれは，檑めて稀な十二指腸原発(乳頭部を除く)腺扁平上皮癌に胃癌を重裇した 1 切除例を経験したので報告する。症例は 78 歳男性. 主訴は胃部不快感. 既往歴は 10 年前より糖尿病にて内服治療中. 現病歴は平成 15 年 6 月頃より胃部不快感を認め他院 にて内服薬処方されていたが改善しないため8月 11 日当院に紹介された。部内視鏡 検査にて胃体上部〜下部小弯を中心とした type3 の腫場と十二指腸球部後壁に type2 の腫骦を認め，生検にてそれぞれから group5（pap）と訅断された．腹部 CT 検查と USにて胃周囲リンバ節の腫大を認めたが，肝転移，嗃隔転移を認めなかったので，9 月 22 日胃全摘術 (D2 郭清) 及び脾膱，胆基摘出術を行った(十二指腸は腫堭の肛側ま で切除)，病理組織学的に胃癌は pap tub（se，ly2,v3）であったが，十二指腸癌は

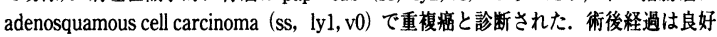
で，術後4 ケ月を経過した現在，無再発生存中で外来補助化学寮法中.

PPS-3-038 外傷性十二指晹損傷手術例の検討

宇高徹総, 西澤鿆吏, 吉田 修, 山根正修, 曽我部長徳, 前田宏也, 水田 稳, 白川和豊, 大屋 崇

（三豊総合病院外科）

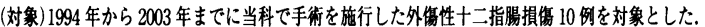

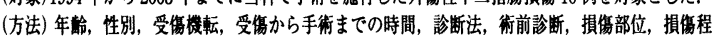

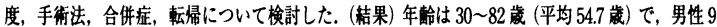

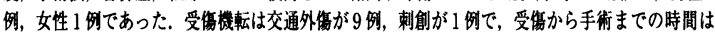
2 96 時間 (平均 18.5 時間) であった。診断法はすべての症例に腹部CT検査が施行されており，

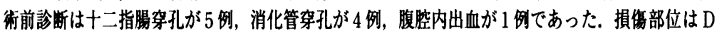

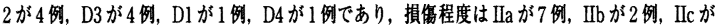

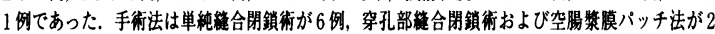

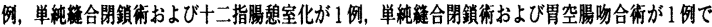

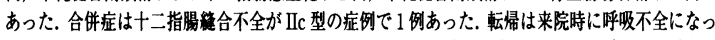

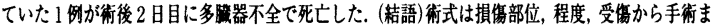
での時間なととにより決定するが，同時に全身状態を考虑に入れて梌討するのが肝要である。

PPS-3-039十二指腸狭窄による喁吐と著明な筫血を来した膡十二指 腸動脈瘤破裂の 1 例

坂下文夫, 八幡和憲, 天岡 望, 長田真二, 杉山保幸, 安達洋祐 （岐阜大学大学院腫瘍総合外科）

今回我々は，十二指腸狭窄による呾吐と著明な盆血を来した羘十二指腸動脈瘤破裂の 1 例を経験したので若干の文献的考察を加え報告する.

患者は 57 歳男性. 10 数年前より羘炎にて近医通院していた. 2 年ほど前からは胃, 十

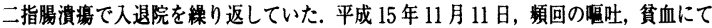
近医入院. GIFにて十二指腸下行脚の粘膜下腫場と同部の㹨窄を認めた. CT では内部 に $15 \times 12 \mathrm{~mm}$ の high density mass を有する $55 \times 45 \mathrm{~mm}$ の十二指腸粘膜下腫場を認め た. 12 月 4 日精查加祢目的にて当院転院となった. 同日，腹部CTを施行したが，前 医でみられた腫㾕は著明に維小していた．出血源の確認のため血管造影を行ったとこ 万後上䐙十二指腸動脈より出血がみられ，コイルにて塞栓した，動脈瘦は確認できな

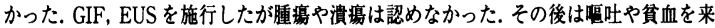
すことなく 12 月 20 日に退院した. 今回の病態を推測すると膡十二指腸動脈嘴破裂に より十二指腸壁内血腫を形成し，十二指腸に害破したものと思われた。

PPS-3-040 早期胃癌に対する分節胃切除術の適応 川手 進", 大和田進", 竹吉 泉", 岩波弘太郎", 浜田邦弘",

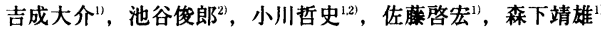
(群馬大学第 2 外科", 前橋赤十字病院外科2)

[目的・対象・方法]術前に $\mathrm{M}$ 領域早期胃癌と診断され, 分節胃切除を施 行した 62 例を胃癌治療ガイドラインと比較し, 縮小手術の妥当性を検討 した. [結果] 観察期間は 7 か月〜 11 年 7 か月 (平均 4 年) であった. 深達 度は $\mathrm{m}$ が 34 例, sm が 27 例, ss が 1 例であった. 腫堭径は $0.3 \sim 5.4 \mathrm{~cm}$ (平均 $3.7 \mathrm{~cm}$ ) であった. ガイドラインで縮小手術 $\mathrm{A}$ の適応外となる分化型 $1.6 \mathrm{~cm}$ 以上の $\mathrm{sm}$ 数は 15 例で, 腫場径は $1.7 \sim 5.0 \mathrm{~cm}$ (平均 $2.5 \mathrm{~cm}$ ), 未分化 型の $\mathrm{sm}$ 癌は 7 例で, 腫瘍径は $0.9 \sim 2.5 \mathrm{~cm}$ (平均 $1.8 \mathrm{~cm}$ ) であった. リンパ 節転移は tub2, $2.4 \mathrm{~cm}$ の $\mathrm{sm}$ 虚の 1 例に認められた. 適応例に 1 例, 非適応 例に 2 例の他病死を認めたが, 全例無再発である. 胃排出能は早期では逻 延しているが経時的に改善した. [まとめ] 分節胃切除例の $37.1 \%$ はガイ ドラインの適応外であったが，予後は良好であった， M 領域の sm 䙖は， 組織型および大きさに関係なく分節胃切除が標準治療となりうる. 
PPS-3-041 D2 リンパ節郭清を伴う分節胃切除：術直後機能におけ る評価

羽藤慎二, 笹子三津留, 大橋真記, 深川剛生, 片井 均, 佐野 武 (国立がんセンター中央病院胃外科)

[背景]器器能を温存しつつ, 必要充分な切除・郭清籁囲を模索する必要性が增加している，胃体中部の

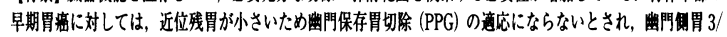
4 あるいは $4 / 5$ 切除か，D0の分節胃切除が行われてきた，我々は，胃体中下部早期胃密に奶して，D2リンパ 節郭清を伴う分節胃切除 (SG) を确行し，検討を行った。

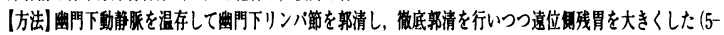

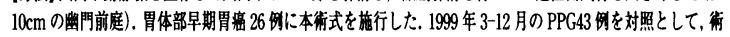
後胃管抜去までの日数，食事開始日，街後在院日数を比㜞した。 また街後残胃透梘にて胃排出能を語僄した。

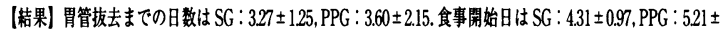

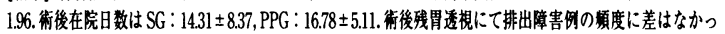
た (SG: 0/0 vs PPG : 0/0).

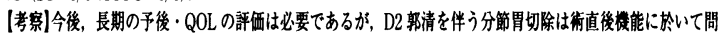

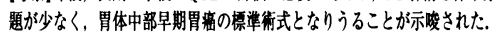

PPS-3-042 幽門輪温存胃切除術の術後評価についての検討 生駒大登, 市川大輔, 生駒久視, 北村和也, 上田祐二, 大辻英吾, 系井啓純, 園山輝久, 萩原明於, 山岸久一 (京都府立医科大学消化器外科)

【目的】今回, 我々はPPG術式を施行した患者の術後評価を行った. 【方法】胃体中部早 期㿋症例のうち, PPG を施行した 28 例を今回の検索対象として, 幽門誠胃切除術（B -I 再建) 58 例を対照に郜床病理学的に比較検討を行い, またアンケート方式によりその 術後機能評価も行った. (成績)PPG 群で $\mathrm{m}$ 癌が多かったが, 两者間の手術時間, 出血量, 術後血液検査, 食事摄取量及び体重娍少に差を認めなかった. PPG 群で術直後食後もた れ感 (44\%vs 36\%) や嗮気 (28\%vs 11\%) を多く認めたが, 術後経過に伴い娍少㑯向に あった. 一方, タンピング症状は有意差をもって幽門側胃切群に多かった $(12 \% \mathrm{vs} 36 \%$, $\mathrm{p}<0.05)$. また, B-I 群で残胃炎を多く認め $(\mathrm{p}=0.04)$ ，逆に食物残渣は PPG 群の方で 多い傾向にあった $(\mathrm{p}=0.052)$. 手術に対する满足度については, PPG 群でやや低い傾向 にあり (84\%vs 96\%, p=0.10), 70 歳以上の高龄者においてはよりその傾向が顥著で あった $(78 \% v s 100 \%, \mathrm{p}=0.07)$. 【結論】 PPG 群で術後患者の満足度は決して高いとは 言えず，高跡者においては特にその適応に注意する必要があると思われた.

PPS-3-043幽門・十二指腸狭窄に対するステント留置の有効性 宮城委史, 今泉拓也, 矢野正二郎, 青柳慶史朗, 孝富士喜久生, 武田仁良, 白水和雄

(久留米大学外科)

切除不能な幽門・十二指腸狭窄症例は食事ができない苦しみの上，経鼻チュープ留置によ る減圧の必要性や胃㹡張による疼有・呼吸障害など患者にとって苦节の大きい病態であ る. 当院ではこの様な症例に対して, 各症例の予後と患者背景 (家族の意向を含む) を検討 し, ステント留置を行うことで十分な QOL 改善が得られると判断した症例に対してステン 卜㨉入術を行っている.今回, 2003 年 10 月から 2004 年 1 月までに行ったステント留置症例 4 症例 (胃癌 3 例, 胆管癌 1 例) についてその効果と実際の方法を呈示する. 全症例におい て, 透視・内視鏡下にオーバーチューフを挿入した上, 食道用の Ultraflex (non-covered type）を延長改良し㨂入・留置した. 施行時の体位は左半側臥位で幽門から十二指晹球部が 透視上直線化した状態が最も挿入・リリースが行いやすいと思われた．また，留置後 3 日

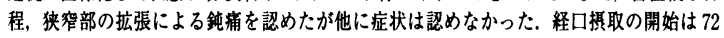
時間後より行い, 現在までステントの脱落や変位は認めず, 軟飯摄取可能となり全症例とも 外来通院が可能となった．また，胃癌 3 症例は経口抗癌剤投与による効果が確認された.

PPS-3-044切除不能上部消化器癌における胃空腸バイパス術施行症 例の検討

澤田正志, 遠藤義洋, 鈴木 雄, 楠田和幸, 天本明子, 三田村篤, 加藤拓見, 鈴木龍児, 北村道彦

(岩手県立胆沢病院外科)

[目的】切除不能上部消化器潘のためにバイパス手術を施行した症例に対し，検討を加えて報告する。対 象・方法平成 11 年 4 月から 15 年 12 月までの 4 年 9 力月間にバイバス手術を檴行した 15 间を対象とし

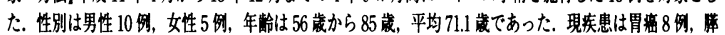

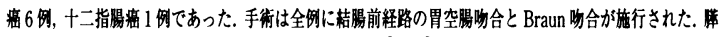

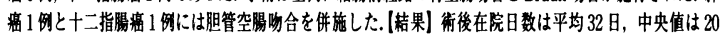
日であった，街後生存日数は平均 265 日，中央值 188 日であった，街後 15 例中 14 例が退院し，この間の 在宅日数は平均 193 日, 中央值は 113 日であった。退院時の掑食量は概及通常の3割から半量程度であっ

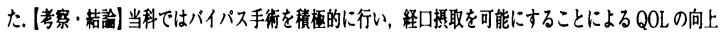

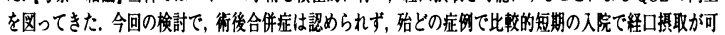
能となり，在宅加橑へ移行できた，術後生存期間的 6 力月のうち䄪 4 力月の在宅が可能であったこれら より,バイパス手術は切除不能上部消化器潘症㘬のQOL 向上に奇与するものと考えられた。
PPS-3-045 胃病末期患者に対する緩和医㞠の現状と問題点 円城寺昭人", 永田康浩", 古井純一郎", 兼松隆之", 山内栄五郎 ${ }^{2}$, 朝永良介 ${ }^{3 !}$, 犬尾浩之 ${ }^{3 !}$

(長崎大学大学院移植・消化器外科", 聖マリアンナ医科大学横浜市西部 病院放射線科 ${ }^{2}$, 朝永病院 ${ }^{31}$ )

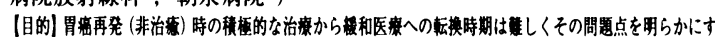

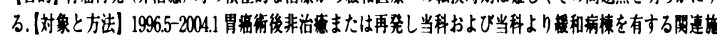

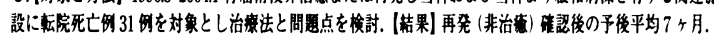

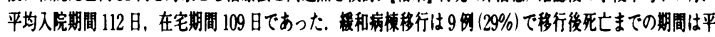

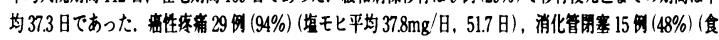

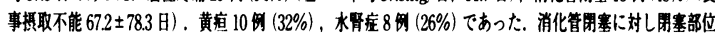

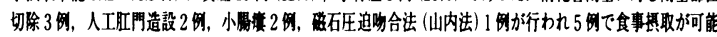

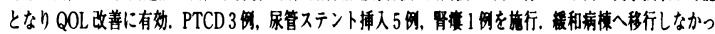

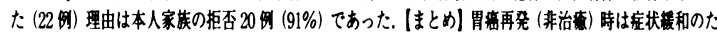

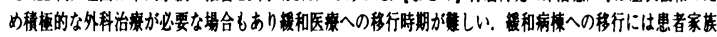

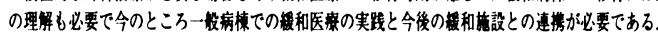

PPS-3-046早期胃癌再発死亡例の特幑と再発形式からみた治療法の 検討

國枝克行 ", 太和田昌弘"，松井 聡", 太田博彰”, 福井貴已”, 河合雅彦", 山口和也 ${ }^{21}$, 安達洋祐 ${ }^{2}$

(岐皋県立岐阜病院外科", 岐阜大学大学院腫䏒総合外科 ${ }^{21}$ )

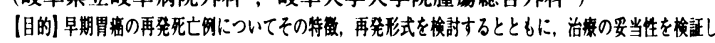

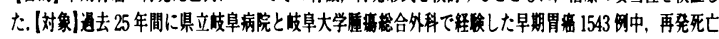

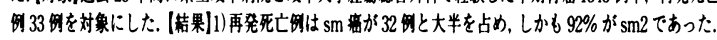

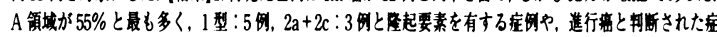

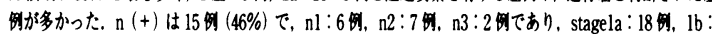

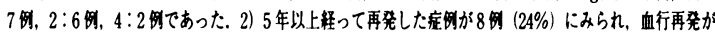

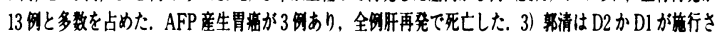

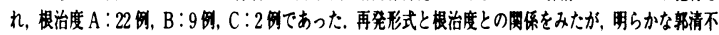

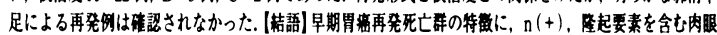

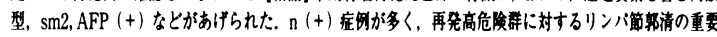

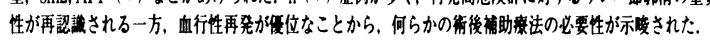

PPS-3-047 右胃大網動脈を用いた CABG 後の胃菑の 3 例 新原 亮, 春田直樹, 大下彰彦, 矢野将翮, 西原雅浩, 渡辺浩志, 杉野圭三, 川西秀樹

(あかね会土谷総合病院外科)

最近 CABGにおいて左右内胸動豚の他に右胃大網助係が使用されることがある. 今回, 右胃

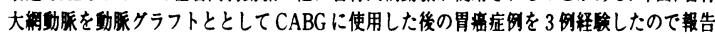
する. 症例 1 は 64 藏男性. 1996 年 8 月 8 日㹨心症でCABG (2枝)を䅦行した. 1998 年 7

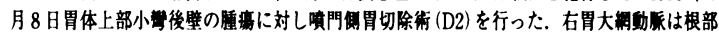

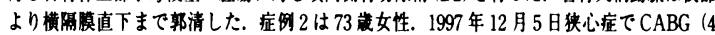
枝)を施行した. 1998 年 10 月 21 日前庭部小及び胃体下部後壁の重槙胃菓に対し胃要全摛

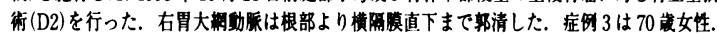

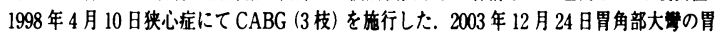

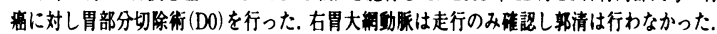
症例 1,2ではCABG 後から胃整発症までが 1 2 年と短く No4d，No6リンバ節の垶清が必 要であったが症例 3 では CABG 後 5 年以上経通しておりまた $\mathrm{m}$ 第であったため No4d, No 6 リンバ節の部清は行わなかった. 全症例とも2004 年1月まで焦再発生存中である.

PPS-3-048 進行胃瘦穿孔に対して保存的治撩後に根治切除を行い, 長期生存中の 1 例

広瀬和郎"，出口正秋"，佐藤嘉紀 ${ }^{2 \prime}$, 村上 真"', 廣野靖夫"',

飯田 敦 ${ }^{2}$, 山口几明夫 ${ }^{2 \prime}$

(町立三国病院外科" ${ }^{\prime \prime}$ 福井大学第 1 外科 ${ }^{2 \prime}$ )

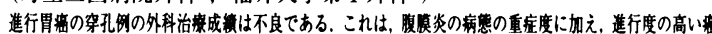

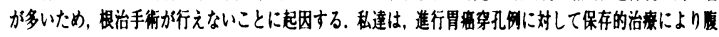

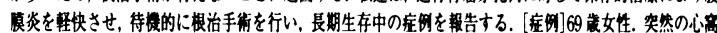

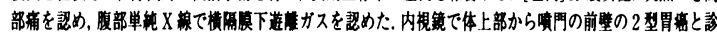

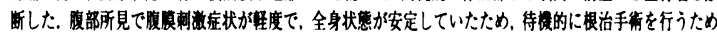

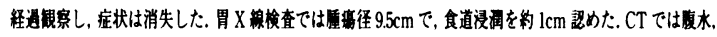

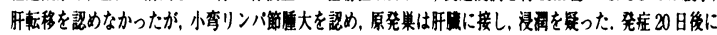

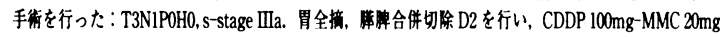
を街中腹脸内投与した，病理診断：tub2, ss, INFB, ly2, v0, pm-, dm-, n2(5/45 因, No.3, 11), cy0, stage

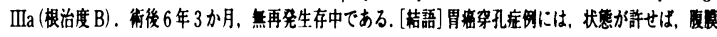

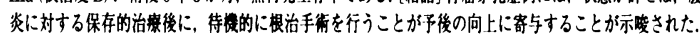


PPS-3-049 胃静脈瘦破裂を契機にみつかった胃癌門脈内腫㾺塞栓の 1 例

成井一隆, 大田貢由, 高倉秀樹, 長領弘太郎, 土井卓子, 若杉純一, 西山婆，高檽俊媇

(国立病院横浜医塨センター外科)

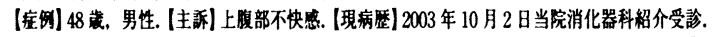

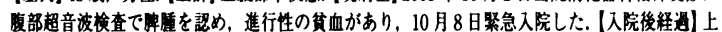

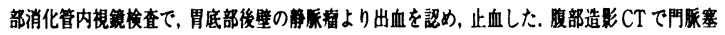

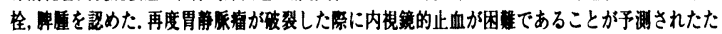

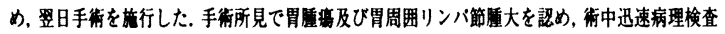

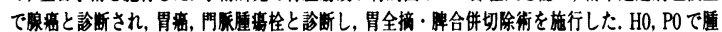

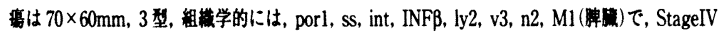

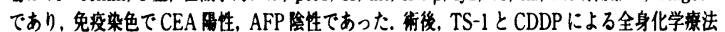

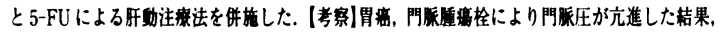

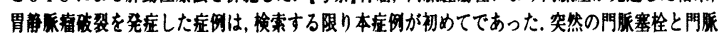

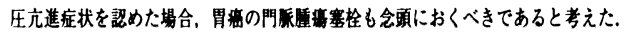

PPS-3-050門腺腫场塞栓, 肝動脈及び総胆管浸潤により急性肝不全 を呈した進行固癌の緊急手術の1例

横山卓, 細谷好則, 狸沼広治, 倉科健太郎, 平䲴勇希, 荒井 涉, 瑞木 亨, 俵藤正信, 安田是和, 永井秀雄

(自治医科大学消化器 - 一般外科)

症例は 67 歲男性. 近医で胃雷と診断され当院紹介となった。腹部 CT および腹部工 コーでは多発肝転移を認め, 門腺内には腫我塞栓を伴っていた. 入院直後より出血の 進行と門腺腫㙞塞栓による肝不全症状やリンバ節転移による閉塞性黄疸の急性增覀 をきたしたため, インフォームドコンセントの下，等急手術を施行した. 開腹すると

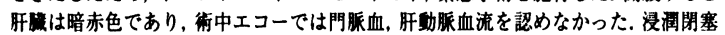

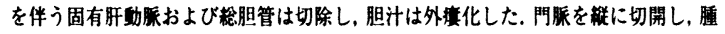

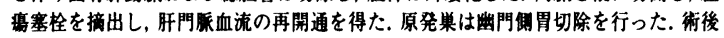
に閉塞性黄㾝は速やかに改善し，的11 ケ月間外来通院可能であった，本症例では，

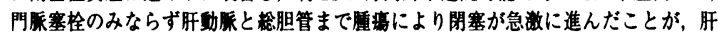

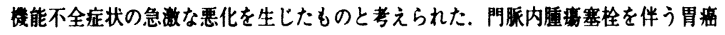

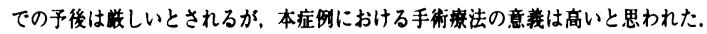

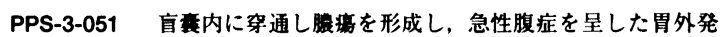
育型胃瘏の 1 切除例

小河靖昌, 河口賀彦, 山崎 透, 吉富彰一, 木村貴彦, 廣瀬 光,

一ノ桷府, 白石隆咗

（市立島田市民病院外科）

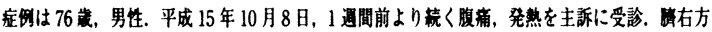

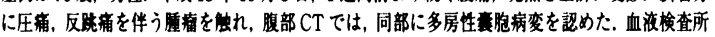

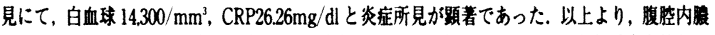

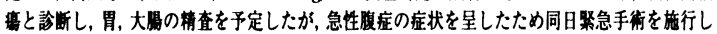

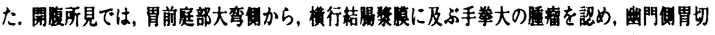

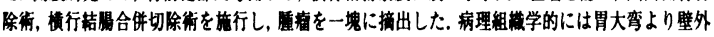

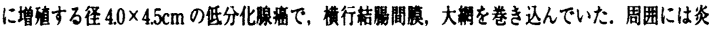

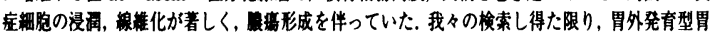

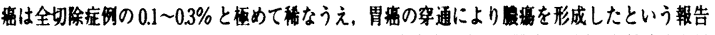

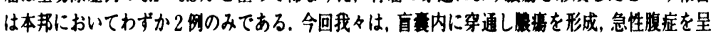

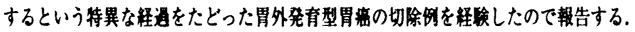

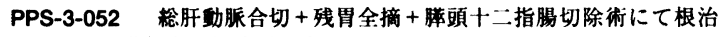
切除出来た進行幽門側残胃の癌の一例

竹林隆介，大山繁和，古賀倫太郎，瀬戸泰之，上野雅资，大矢雅俊， 山本順司, 山口俊晴

(密研究会病院消化器外科)

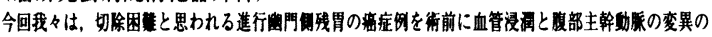

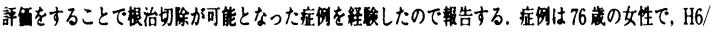

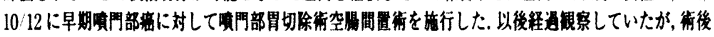

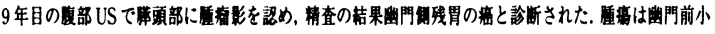

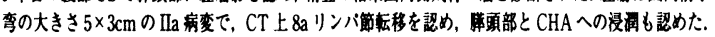
同時にSMA からRHA が分枝していることも明らかになり，切除可能と判断し，H15/6/30に手街施

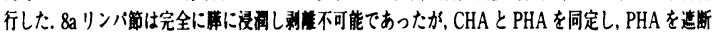

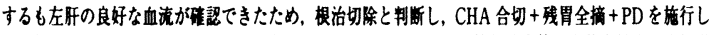

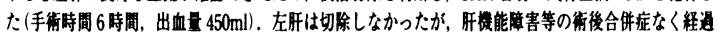

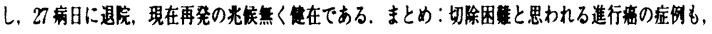

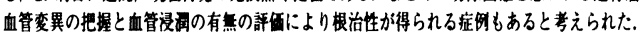

PPS-3-053 胃扁平上皮癌の 1 例

吉田達也, 村上仁志, 円谷 彰, 小林 理, 西連寺意勲, 本橋久彦 (神奈川県立がんセンター消化器外科)

症例は 63 歳, 男性. 平成 15 年 6 月頃より前胸部のつかえ感あり, 近医 受診. 上部消化管内視鏡検査で異常指摘され当院紹介となった. 初診時, 血液生化学検査：異常なし, CEA $1.1 \mathrm{ng} / \mathrm{ml}$, CA $19-98.9 \mathrm{U} / \mathrm{ml}$, CA 125 $18.9 \mathrm{U} / \mathrm{ml}$ と正常, SCC 8.1ng $/ \mathrm{ml}$ と上昇を認めた. 術前 CT で右噴門, 小 弯リンパ節の腫大を認めた. 上部消化管内視鏡検査で ECJ 直下小弯側に $5 \mathrm{~cm}$ 大の 1 型腫場認め, 生検で扁平上皮䄆と診断された. 8 月 25 日胃全 摘術施行. 病理診断は well differentiated squamous cell carcinoma, ly 0 , v3. 腺癌成分は認められなかった. UE, Less, type 1, f-T3N1HOPOCY 0M0, stageIIIA であった. 10 月に多発肝転移が出現, 翌年 1 月に第 1 腰椎への転移による圧迫骨折をきたし, 現在 TS-1/CDDP 療法を施行し ている. 胃の扁平上皮癌はまれな疾患であり, 当院での 1986 年から 2002 年の胃病手術症例 3190 例中, 腺扁平上皮癌を含めても 7 例を認めるの みである. 文献的考察を含めて報告する.

PPS-3-054術後早期に広範なリンパ節再発をきたした胃腺扁平上皮 癌の 1 例

宅間邦雄, 足立健介, 高見 実, 大島 哲, 高西喜重郎, 井上 仁, 松本 潤

（東京都立府中病院外科）

胃腺扁平上皮盘は此较的稀な組機型で，胃癌取り扱い規約では特殊型に分類されている．今回，わ

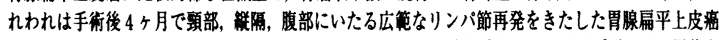

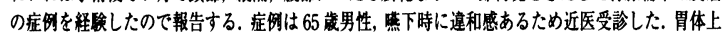

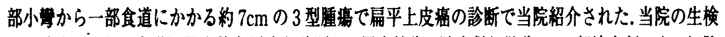

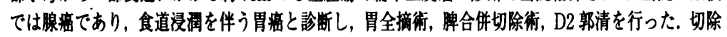

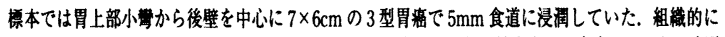

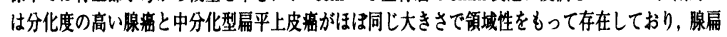
平上皮艒と診断した，病理組維診断はly3 v2 pT2 (ss)，pN2 (1,2,3,7 番に轱移)， sH0, sP0, sM0, fStage 3 A であった. 街後経逍は良好で第 15 病日退院した. 街後 4 ケ月で CEA $500 \mathrm{ng} / \mathrm{ml}$ に急上舁,

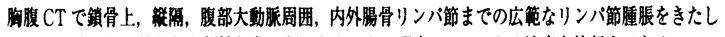
ていたが肺，肝，骨なと血行性転移は認めなかった。現在 TS-1による治療を施行中である.

PPS-3-055 胃 GIST と術前鑑別困難であった結腸癌胃壁転移の 1 例

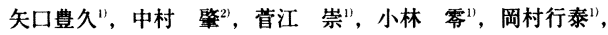

石山聡治", 高瀬恒信 ${ }^{11}$, 中山茂樹", 原田明生 ${ }^{1}$

(厚生連海南病院外科"，なかむらクリニック

我々は術前に胃 GIST と診断, 術後の病理診断にて結腸癌の胃壁転移であった1例を 経験したので報告する. 症例は 64 歳男性. 2003.9 月，心窩部痛を主訴として近医を受

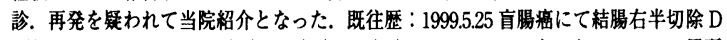
3 施行. muc ss ly2 v0 n1 (+) n2 (+) n3 (-), stage IIIbであった. 2002.4.17 局所

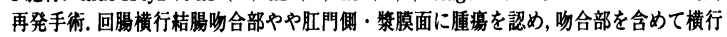
結晹部分切除を行った. 今回の検查所見：CTにて腈上部腹壁直下に $3.5 \mathrm{~cm} の$ 結節を 認めた. 腹部超音波検査では低エコー像として描出された. 胃内視鏡では体下部大弯僛 に表面平滑な球形の隆起性病変を認めた。手術所見 $(2003.11 .20)$ : 腹膜転移は認めず, 幽門から胃角部の前壁に表面平滑な腫渭を認めた. 手術：幽門側胃切除 D0を行い, B -I 法で再建した. 第 15 病日軽快退院した. 病理所見は結腸癌の再発で壁内から增大し

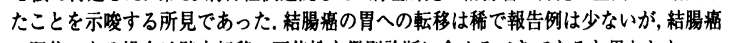
の既往のある場合は壁内転移の可能性も別診断に含めるべきであると思われた.

PPS-3-056 胃癌治瘾切除術後, 4 年で発症したテストステロン産生性 の卵巣・子宮転移の 1 例

山田圭一", 足立信也 ${ }^{21}$, 川崎卓也", 高野恵輔"), 及川明奈"1,

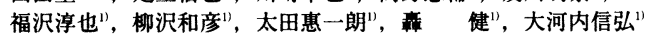

(筑波大学消化器外科", 筑波メディカルセンター病院・茨城県地域がん センター ${ }^{21}$ )

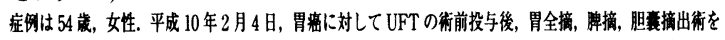

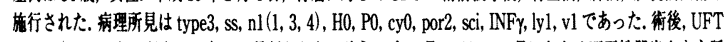
$300 \mathrm{mg} / \mathrm{body}$ の释口投与が 1 年 5 ケ行われた. 平成 14 年 4 月 24 日, 2 ケ月にわたる不正性器出血を主訴

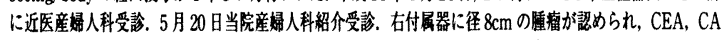
19-9,CAl25,エストラジオール，は基哖值䉐囲内，テストステロンは $140.9 \mathrm{pg} / \mathrm{ml}(6.0 \sim 86.0)$ と血中テスト

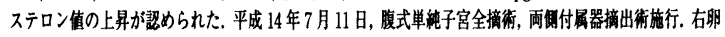

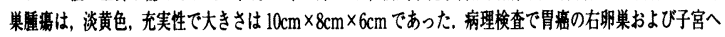
の轱移と診断された，血中テストステロン值は，術後 5 日目には $12.5 \mathrm{pg} / \mathrm{ml}$ と基草值簐用内となった。術後,

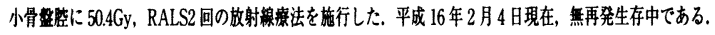
テストステロン産生性の卵巣，子宮転移は梗めて稀であるので考察を加え報告する。 
PPS-3-057胃癌手術 12 年後に吻合部再発及び腹膜播種を発症した 一例 清川厚子, 中場寛行, 松田康雄, 森口 聡, 末岐博文, 前田 晃, 藤井 仁，奥田倫久，大口善郎 (国公共済連大手前病院外科)

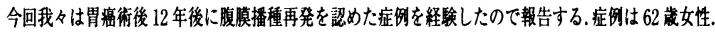
平成 3 年 6 月残胃滛にて残胃全摘術 (空腸間置再建) 施行 (T4 (sei/liver) N0 (no.12) H0 P0 M0 stage

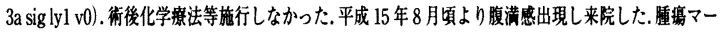
カー值は正常であった。注腸・CFSにて横行結晹脾弯曲部に高度㹨窄を認め,CT では同部位に造影効

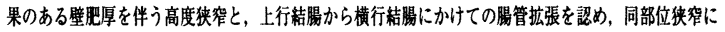
よるイレウスと診断し，平成 15 年 12 月手術施行した，開腹時の腹水細胞診では signet ring cell car-

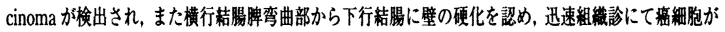
検出された，横行結腸・下行結腸バイバス術を施行した，街後，GIF 施行したところ食道空腸吻合部 に狭窄認め，生検にて signet ring cell carcinoma が検出された，現在は weekly paclitaxel 施行中で

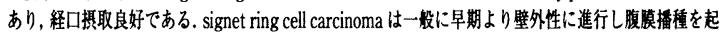
こしやすく，10年以上経過しての発生は稀であり，若干の文献的考察を加え報告する。

PPS-3-058 長期生存しえた胃癌肝転移の 2 症例

虎島泰洋, 奥平定之, 岸川博紀

(光晴会病院外科)

【はじめに】胃癌の肝転移症例は一般的に予後不良である。今回我々は肝転移再 発をきたし外科手術により現在まで無再発となった症例を報告する. また現在 集学的治療を施行中である胃癌肝転移症例を示す. 【症例 1)79歳, 男性(現病歴] H9 年幽門側胃切除術施行. Stage III a であった. 術後化学療法施行した後, 外 来通院中であったが, $\mathrm{H} 10$ 年肝 S4 に肝転移出現. TAE 予定したが動胍蛇行のた め施行できず, 4/8 肝部分切除術施行. 以降経過みていたが, H12 年再び肝 S5 に転移出現. $5 / 15$ 肝部分切除術施行した. それ以降胃癌再発の兆候みられてい ない. $\mathrm{H} 15$ 年肺扁平上皮癌発症し $11 / 20$ 右下葉切除術施行. 現在外来通院中であ る. 【症例 2】 54 墄, 男性【現病歴】 H12 年胃全摘術施行. Stage III bであった。 術後化学療法行っていたが, H13 年肝転移出現し TAE 2 回施行. H14 年 2 月, 開胸肝腫韵焼灼術施行し, TS-1 内服を開始した. 肝腫湯増大あり H15 年 7 月肝 動注ポート㨂入し, 現在肝動注および全身化学療法併用し通院中である.【まと め】胃癌肝転移症例でもその治療法を適切に選択し予後の改善が可能である.

PPS-3-059手術時下腹部の腹膜播種陽性で, 合併切除により 5 年間 無再発生存を得た胃癌の 1 症例

龍見謙太郎, 沖野 孝, 瀬戸山博, 寺村康史, 井田 健

（公立甲賀病院外科）

腹膜播種転移を伴う進行胃庫に対し積極的切除を行い, 術後 5 年間の無再発生存を得た 症例を経験したので報告する。

症例は 50 代女性. 心窨部痛にて発症し, 精査にて胃体下部に 2 型病変を認め, 生検で中 分化型腺癌と診断されたため, 手術となった. 主腫場は䄪 $7 \mathrm{~cm}$ 大で胃体下部大娐に位置 し, 横行結腸および䐙体部へ直接浸潤していた. また, 回腸末端より $65 \mathrm{~cm}, 100 \mathrm{~cm}$ の回 腸, および上行結腸に計 3 力所の数 $\mathrm{cm}$ 大の壁外性腫瘫を認め, 腹膜播種と考えられた. これに対し, 胃全摘, 滕体尾部・脾・胆表・右半結腸合併切除, リンパ節 D3 郭清を施行 した、組織学的検査においても回腸, 上行結腸の壁外性腫瘁は槳膜㑡より粘膜㑡に向かう 腺癌であり, 胃䍃の腹膜転移と考えられた，退院後, 術後補助化学療法として MTX $/ 5$ -FU 療法を半年間行い, その後はUFT 内服へ変更した. 半年ごとのCTにて転移, 再発 は認めず,術後 5 年間健存である.腹膜播種を伴った進行胃癌でも肉眼的に切除可能と判 断された場合，積極的に切除を行うことにより，長期生存を得られる場合がある.

PPS-3-060 初回手術から 10 年以上を経た再発胃瘦の 2 切除例 飯田辰美, 水谷憲威, 宮原利行, 後藤全宏

(厚生連 西美濃厚生病院外科)

【症例 1】 72 藏女性 主訴: 肝腫瘤 既往歴: 1987 年進行胃癌で胃全摘術, C 型肝 炎 1996 年胆石症で胆摘術 現病歴: 経過観察中の 2001 年秋, 肝腫㿎が認められ 当科に入院. 現症：腹部に 2 䇢所の手術創. 検査 : 貧血と腫瘍マーカーの上昇があっ た. CT, MRIで肝外側区から膡頭側に連なる腫智と肝前後区域境界に腫瘤が認めら れた. 手術 : 肝外側区域切除. 㞬腸脚から䐙に連なる腫堭と前後区域境界の腫堭には ラジオ波焼灼. 病理組織標本: 腺癌で胃㗯再発と診断された. 転㷌: 再手術後 2 年 2 ヶ月脳転移を来たし再入院中である. (症例2】 51 歳女性 主訴：負血 既往歴： 1988 年進行胃痻で胃全摘術, 糖尿病. 現病歴: 2002 年糖尿病にて当院内科で治療中 に貿血を指摘され精査となった. 現症：腹部に手術創あり.眼瞼結膜に筫血あり. 検 査：注腸造影と大腸ファイバースコープで横行結腸の狭窄があった. 手術：横行結 腸切除術を行った. 病理組織標本 : 槳膜側からの印環細胞瘦で結腸が狭窄していて 胃癌再発と診断された. 転㷌：再切除後 1 年 8 ケ月外来通院中である.【考案】 10 年以上の間隔をおいて再発する胃粘はまれである. 長期の経過観察を有感した.
PPS-3-061胃笛同時性多発大腸転移の 1 例

金澤英俊，和田英見，鍵本紀久雄，長野郁夫，山田育男，山田 昂 (碧南市民病院外科)

症例は，79歳・男性. 上部消化管造影で，胃幽門前庭部に不整陰影を認め，当院紹 介. 血液検査では，CEA $79.2 \mathrm{ng} / \mathrm{dl}(<5)$ と上.䄯，上部消化管内視鏡で，胃体下部

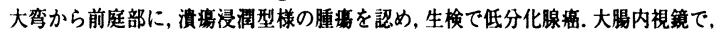

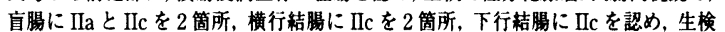

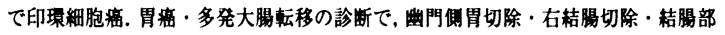
分切除を施行. 胃では, $40 \times 38 \mathrm{~mm}$ の扁平隆起，䊅節を伴う 5 型の腫場を，盲渴に

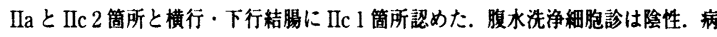
理は，胃は porl, sm，n2, ly3, v1, pm (-)， dm (-) で，結腸は粘膜内あるいは 粘膜と粘膜下層への胃腄場の転移と診断. 術後覚醒不良あり，頭部 CT で, 著明な 媨浮腫を認め, 全脳虚血と診断. 術後第 7 病日永眠. 本症例は、腹水絧胞診が陰性, 胃癌の深達度は smであり，組穖学的にリンバ管侵襲が著明であったことから、リ ンパ行性に転移したものと考えた．胃癌の術前検査で大腸病変の生検耛果が低分 化腺癌や印環細胞缯であった場合，胃痘大晹転移を念頭に置く必要がある。

PPS-3-062右胃大網動脈を使用したA-Cパイパス術後に発症した 胃癌の 1 切除例

清水淳三, 平能康充, 木下静一, 龍沢泰彦, 川浦幸光

(済生会金沢病院 外科)

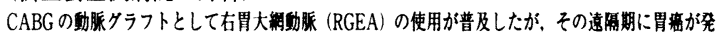

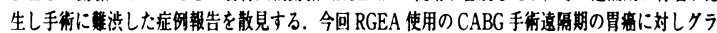

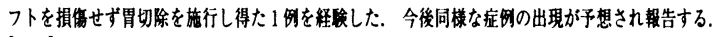

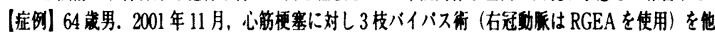

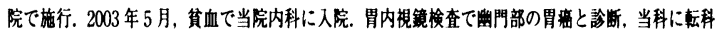

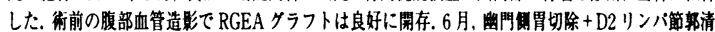

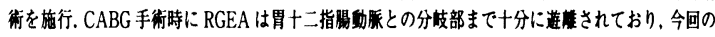

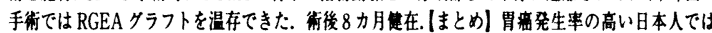

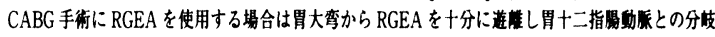

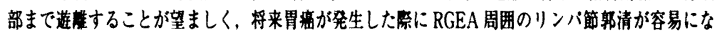
ク,クラフト損侮の可能性も沙する。ま 行い早期発見に努め, 早期なら EMR で治薄可能なので敬重な follow upが肝要である.

PPS-3-063 满切除後に生じた胃瘦の 3 例

平 成人, 栗田 啓, 棚田 稳, 久保義郎, 青儀健二郎, 石崎雅浩, 柿下大一, 沖田理貴, 沖田旮司, 高㟃成光

(国立病院四国がんセンター外科)

羘切除後に生じた胃癌の 3 例を貫重と考之星示する. (症例] 症例 1 ：男性, 群切除

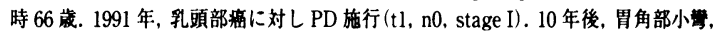
$2.4 \times 1.0 \mathrm{~cm}$, IIc 病変を指摘され EMR 施行 (tubl, m, VM $(-), \mathrm{LM}(-))$. 症侏 2 : 男性, 羘切除時 69 藏. 1995 年, 胃体上部小清 IIc 病変に対し EMR 施行（tub

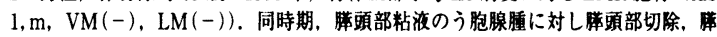
胃吻合術施行. 5 年後, EMR 般痕部再発. 同時に体中部後壁に $6 \mathrm{~mm}$ 径, 瞵胃吻合 部に $1 \mathrm{~cm}$ 径の IIc 多発病紧を指摘され胃全摘術, 滕部分切除を施行. 主病单は愺胃

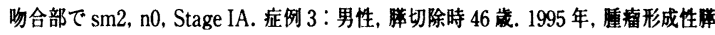
炎に対し羘胃吻合による PPPD 施行. 6 年後, 前庭部前壁に $1.3 \times 0.5 \mathrm{cmIIc}$ 病変を指 摘され局所切除術 (por, sm2, ly2, v0). さらに 2 年後, 胃譜伆合部に $3.1 \times 2.4 \mathrm{~cm}$, IIa + IIc 病変を指摘され幽門㑡胃切除, 胼部分切除術を施行 (mp, n0, Stage IB). 3 例とも無再発生存中. 各々の症例における問題点, 術式の工夫等を報告する.

PPS-3-064 下行脚から水平脚への広範な狭窄を呈した特異な十二指 晹炎の 1 例 田中聡行, 花崎和弘, 池野龍雄, 佐藤敏行, 尾崎一典, 町田水穂, 市川英幸, 川口研:-

(厚生連篠ノ井総合病院外科)

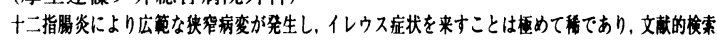

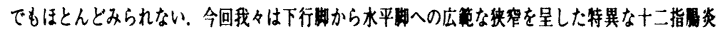

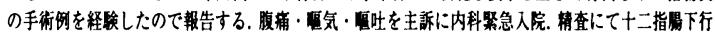

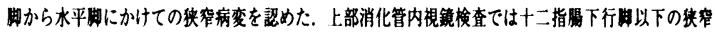

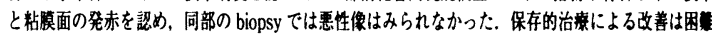

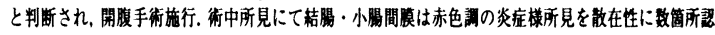

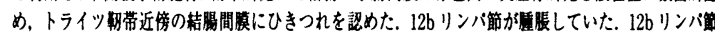

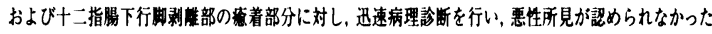

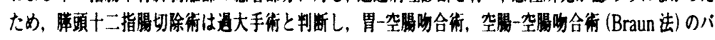

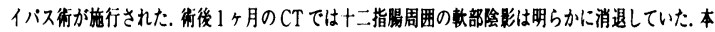
病変形成の mechanismについてより詳細な病理学的および文献的検索も含めて報告したい. 
PPS-3-065幽門狭窑症にて発症した十二指腸クローン病の 1 例 柳生隆一郎, 藤原由規, 井上貴至, 小石健二, 西脇 学, 池内浩基, 中川一彦, 山村武平

(兵庫医科大学第 2 外科)

【症例】患者：40葴，男性. 現病歴：体重減少，食欲不振，喂気，洍吐にて精査し たところ，GIF，UGIにて幽門部から球部にかけての狭小化が著明であり，腹部 US で腿壁の肥厚を認めた. Helicobacter Pylori 謁性であったことより十二指晹潰堭

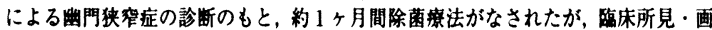
像所見ともに改善を認めず外科的手術を施行した. 術中迅速, 術後永久標本の病理 検査においても十二指渴壁・胆貫壁に類上皮肉芽腫を認め,クローン病を示唆する 所見であった【考察】クローン病は全消化管に病変を及はすことが知られている

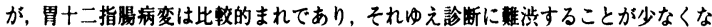
い. 診断の荤れからくる患者のQOL の低下を引き起こさないよう留意することが 必要であり，そのためには生検を含めた内視鏡診断の向上が求められる.【結語】術 前診断が困醮であった十二指晹クローン病の1例を経倹した。幽門狭窄症，十二指 腸㹟窄症の原因の一つとしてクローン病も念頭に置いた緮床診断が必要である.

PPS-3-066術前診断に㫿涉した十二指晹狭窟の 2 症例

亀井義明, 串㚼史樹, 大谷広美, 中村太郎, 森本真光, 福原稳之, 山下広高, 八杉 巧, 本田和男, 小林展章

(爱媛大学第 1 外科)

库例 169 藏男性，条楬色の吐物あり，内梘鏡，上部消化管造影にて十二指渴下行制は全周性に

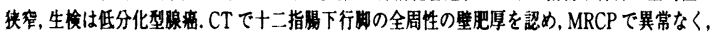

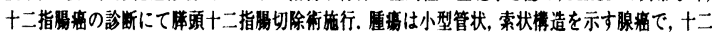

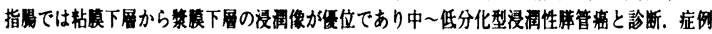

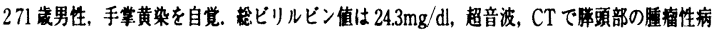
変と,それに伴う閉塞性黄疸と判断.内梘鏡では十二指得粘莫の発赤とびらんを認めるも生検で

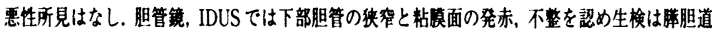

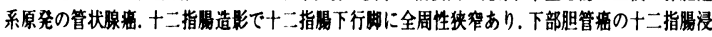

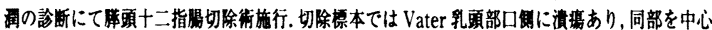

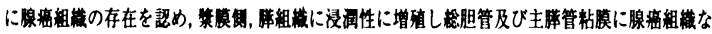

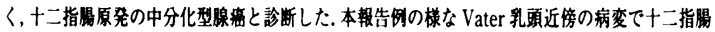

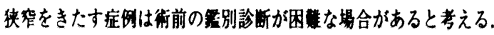

PPS-3-067十二指晹粘液癌を重椣した遗伝性非ポリポーシス大腸㿋 の 1 例

楖生利彦 ${ }^{1}$ ，相原 司 ${ }^{1}$ ，村山道典"，菊地勝一" " 中村栄秀"

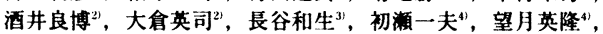

田村和朗 ${ }^{5}$

(自衛际神病院外科"，自衡隊富士病院外科 ${ }^{21}$, 自衡隊中央病院外科 ${ }^{3}$, 防得医科大学校第一外科 ${ }^{4}$, 兵庫医科大学先端医学研究所家族性腫场部 門 $^{\text {(i) }}$

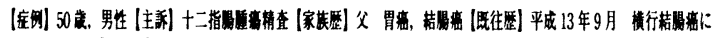

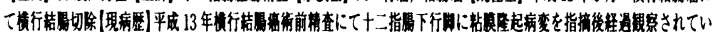

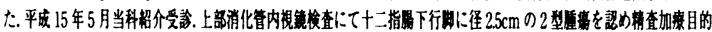

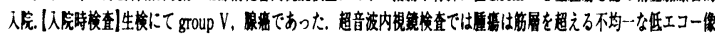

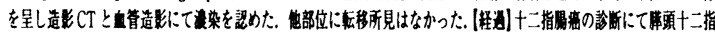

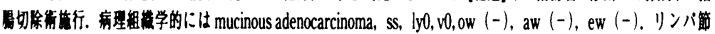

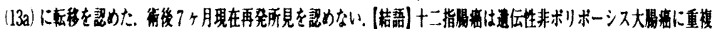

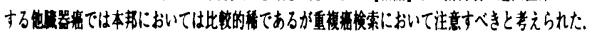

PPS-3-068 突発性大網出血の一例

平原典幸"，仁尾義則"，西健"，三瓶訓子"，桶上哲哉" (津和野共存病院外科" , 島根大学第 1 外科 ${ }^{2}$ )

【目的】大網出血は何らかの原因にて腹㓐内や大網内へ出血を来す病態である. 今回,

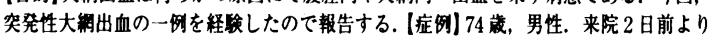
腹施が出現したが增強しないため放置. 来院当日夕刻より腹浦が增強し左肩への放散

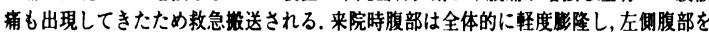
中心に自発萧・压有を認め, 軽度筋性防御を伴っていた。全身状悲は安定し, 軽度炎症 反応を認めるのみであった. エコーにて大量の腹水と左上腹部に肝隌よりやや低エ

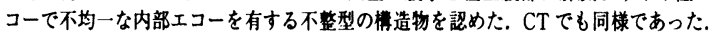
腹水穿剌を施行したところ血性であり，この間的 2 時間で筫血の進行を認めた. 以上よ

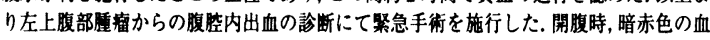
生腹水を多量に認め，大椆左㑡に巨大な疑血塊を認めた. 大網の脂肪内に包まれるよう

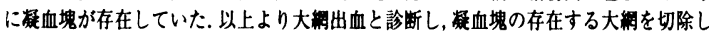
手術終了. 病理学的には一部線維化を伴う脂肪組繳を背累に出血性変化を認めるのみ であった【結語】非常に稀な原因不明の突発性大網出血の一例を経釦した。
PPS-3-069 胃石に対する鮒田式胃壁固定具を利用した局麻下胃内手 術

有永信哉, 切手俊弘

(高田中央病院外科)

患者は 83 藏男性, 2 日前から食欲不振となり腹浦も出てきたので来院. 初診時, 心窩部の圧

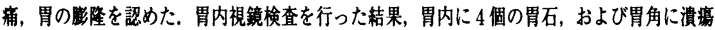
を認め入院となる．内視镜の鉜子で胃石の粉碎を武みるが容易には壊れなかった。この患者

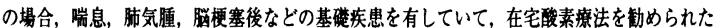
おり，麻醉，手術のリスクは高いと考えられた。そこで胃内視镜下に腹壁から局麻下に鉗子

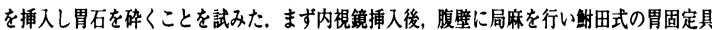
を用いて体部前壁を腹壁に 3 䇢所固定. その中央部を皮成切開して $5 \mathrm{~mm}$ のトロッカーを㨉

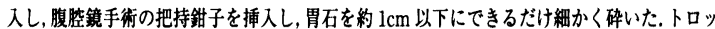
カーを枝去して，その部を内視镜下にクリッピンクして開鎖. 出血，皮闻へのエアーリーク のないことを礁認し手術を終了した.吊り上けた系壮安全のため 5 日間留置した. 2 日後胃内 から胃石は消失しており症状なく良好に経過した：この手技は，局麻でできる，胃壁の路合 をクリッピンクで行うなど，籣便であり他の胃内手術へも応用できると思われた，

PPS-3-070原発性隆起性病変を呈した Gastritis Cystica Profunda の 一切除例 (病理所見を中心として)

川久保雅祥"，䚺訪達志"，内田智夫 ${ }^{1}$, 佐々木貴浩1), 星川竜彦”, 佐藤宏喜 ${ }^{11}$, 古内孝幸 ${ }^{1}$, 竹中能文 ${ }^{11}$, 佐久間正祥 ${ }^{11}$, 堀真佐男 ${ }^{2}$ (水戸赤十字病院外科"，水戸赤十字病院病理検査科2)

胃の原発性隆起性病変としての Gastritis Cystica Profunda (GCP) は梗めて稀であり，その肉眼所見と

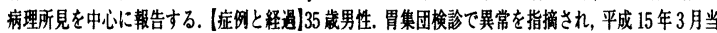
院受診. 上部消化管検查では，前庭部大粼に最大径約 $4 \mathrm{~cm}$ の扁平隆起性病変を認めた。同部の生検を

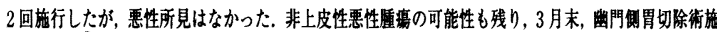

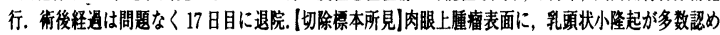

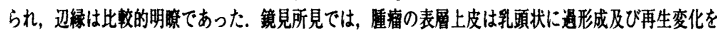

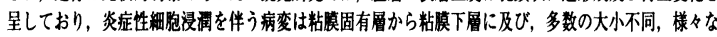

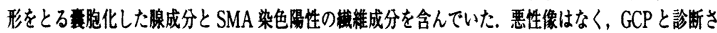

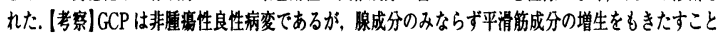

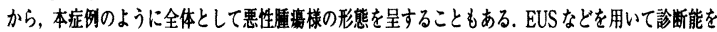
高めることにより，切俆を回繁して経通锤察していくことも可能で今後の課題としていきたい，

PPS-3-071 短期間に急速増大した胃 inflammatory fibroid polyp の 1 例

小野文徳, 吉田節朗, 内山哲之, 原田昭彦, 神山篤史, 益田邦洋, 小野地章一

(仙北組合総合病院外科)

短期間に急速增大した胃 inflammatory fibroid polyp の 1 例を報告する. [症例] 70 歳男性 【主訴】特になし【既往歴】 24 歳時に胃炎【現病歴】検診にて要精查となり受診. 胃角部 前壁に粘膜下腫瀻様病変を認め経過観察となるも 3 力月後に明らかな增大と形態変化あ り入院. (検查所見)負血と血小板数增加, CRP および可溶性 IL2R 高值. (上部消化管内視 鏡】内脄に隆起する腫鸤で頂部の粘膜は欠損. 生検で悪性所見なし. ICT]周辺部が淡く造

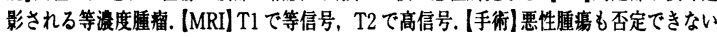

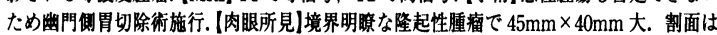
黄白色荡で, 充実性, 弾性硬の腫湯. [病理組織所見]粘膜下層を中心に線維芽細胞, 線維 練胞の增殖，好酸球やリンパ球の漫阔，更に豊富な毛細血管と onion-skin pattern を認め inflammatory fibroid polyp と診断. (考察】胃 IFP の報告例の大部分は $2 \mathrm{~cm}$ 以下だが，本 症例のように $4 \mathrm{~cm}$ 以上になるものや急速な增大や形態変化を示した例も存在する.

PPS-3-072 胃瘦の同入院期間中における再開腹症例の検討 岩坂尚仁, 花城德一, 坂東儀昭, 三好康敬, 村澤正甫 (健康保険鳴門病院外科)

【目的】胃的手術例の内で同入院期間中における再開腹例について検討した. (対象と 方法】1986 年 1 月から 2002 年 12 月までの $24 / 796$ 例 (平均年龄は 67.5 歳) を対象と して検討した.【結果】初回術式は, 幽門㑡切除 16 例, 全摘 6例, PPG 1 例, 切除不 能 1 例で, 再建術式は, Billroth-I 法 12 例, Billroth-II 法 4 例, Roux $-Y$ 法 6 例, 胃々

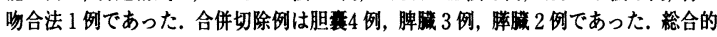
進行程度は StageIA 10 例, IB 2 例, II 2 例, IIIA 2 例, IIIB 1 例, IV 7 例であった. 再開腹までの期間は 2 88 日で, その原因はイレウス 6 例, 䋖合不全 5 例, 腹䏶内展 瑏 3 例，壊死性腸炎 2 例，aw $(+) 2$ 例，胆汁性腹膜炎 1 例，十二指腸断端の穿孔 1 例, 腹腈鏡下胃部分切除後の $\mathrm{sm}$ 例 1 例, 腸瘦の必要例 1 例, 創し開 2 例であった. 予後では，癌死は 4 例ですべて StageIV，入院期間は平均 123.8 日で，他病死は 3 例で StageIIIA 1 例, IV 2 例，入院期間は平均 34.7 日であった.【まとめ】 20 例が術 後合併症によるもので，4例の瘦死例は合併症がなければ退院が可能と考えられた ため進行度の高い症例には特に合併症を回避する努力が必要である. 
PPS-3-073 POSSUMによる胃㿋手術症例のリスク評価 中島 修"，保田尚邦"，片山和久"，森永暢浩"，鈴木一也"， 根岸 健" ${ }^{1}$, 大中 徹", 神坂幸次", 渡辺 諴 ${ }^{2}$, 草野満夫 ${ }^{21}$ (伊势崎市民病院外科", 昭和大学一般消化器外科 ${ }^{21}$ )

【はじめに】個々の患者の病態を術前に把握し手術のリスクを評価することは周術 期管理を行う上で重要である. (目的) 今回我々は本邦における胃癌手術症例に対 するPOSSUMの有用性について retrospectiveに検討した.【対象と方法】 2003 年 1 月から 2003 年 12 月までに当科にて施行された初回胃癌手術症例 74 例を対 象とした. POSSUMのスコア表にしたがって全症例の Physiological Score(PS) と Operative Severity Score (OSS) を点数化し, 予測術後合併症を算出した. [結果] 男性 50 例女性 24 例, 平均年龄は $63 \pm 11.1$ 嵅. 術式は胃全摘術 30 例, 嗔門側胃切 除術 2 例, 幽門僋胃切除術 38 例, 部分切除術 4 例, stage 別には IA 23 例, IB 9 例, III0 例, IIIA 19 例, IIIB 2 例, IV 11 例であった. 術後合併症の発症は 74 症 例中 19 例 $(25.8 \%)$. POSSUM からの予測合併症率は $50.2 \%$ であった. OSS が術 後合併症の評価に侵位に関与していた $(\mathrm{p}<0.01)$. [結語]本邦の胃癌症例に対して は過㮃に算出されており，本邦の特徵に合わせた修正の必要が考えられた。

\section{PPS-3-074 重度 COPD 合併胃癌手術症例に対する術前術後管理の}

工夫

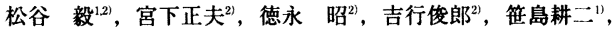

丸山 弘", 松田明久 ${ }^{2}$, 鈴木成治"), 江上 格", 田尻 孝"

(日本医科大学多摩永山病院外科 ${ }^{1}$, 日本医科大学大学院腈器病態制御外 科党)

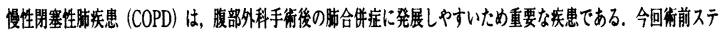

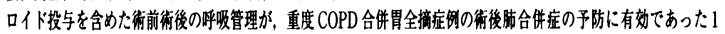

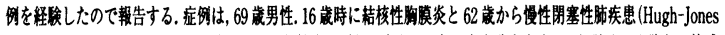

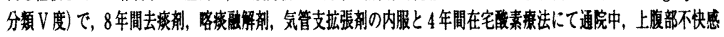

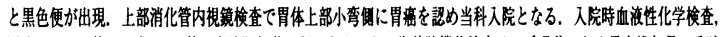

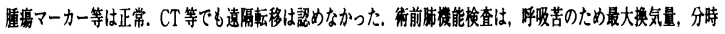

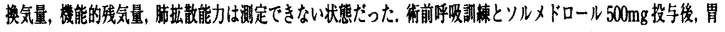

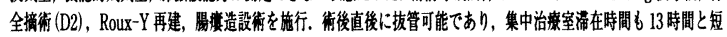

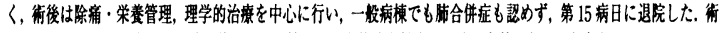

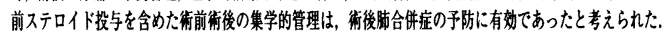

PPS-3-075 脾合併摘除を行った胃切除術後苏液瘎の検討 中山壽之, 青木信彦, 增田英樹, 林 成興, 間崎武郎, 若林和彦 (日本大学練馬光が丘病院外科)

【目的】胃全摘術では脾門リンバ節郭清のため脾合併摘除が行われているが, 時に術

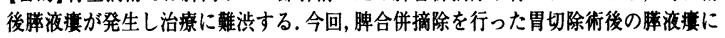
ついて検討した. [対象と方法]対象は胃切除術を施行された胃䌊患者 448 例中，脾譄

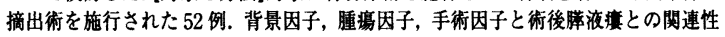
を検討した.【結果】術後滕液瘦を 18 例（34.6\%）に認めた. 17 例に保存的加療, 1 例に再開腹ドレナージ術が施行された，滕液掅発生の有無と, 年龄, 性別, 高血圧, 糖尿病, 膦尾部合併切除, 胆毫合併切除, 横行結腸合併切除, 肝合併切除, 胃癌肉眼 分類, 腫堭占居部位, 腹膜転移, 肝転移, 遠隔転移, 手術時間, 出血量, 組織訅断, 静腺侵㜔には有意な差を認めなかった。胃壁深達度 $(\mathrm{p}=0.030)$, リンパ節転移 $(\mathrm{p}=$

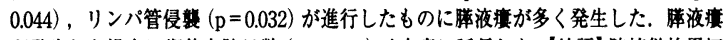
が発生した場合に術後在院日数 $(\mathrm{p}=0.002)$ は有意に延長した.【結語】脾摘併施胃切

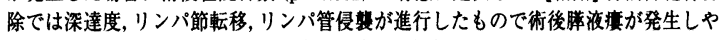
すく，一層暗切なドレナージと術後画像診断を行うことが必要である.

\section{PPS-3-076 胃癌術後障害 (QOL)の定量的測定による術式評価と六君} 子湯の効果

滝口伸浩"), 永田松夫 ${ }^{11}$, 早田浩明", 山本 宏" ${ }^{1}$, 伊藤泰平 ${ }^{11}$,

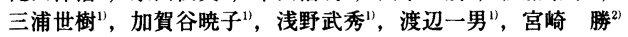

(千葉県がんセンター消化器外科", 千葉大学大学院澸器制御外科学 ${ }^{2}$ )

【目的】胃切除後障害の程度をアンケートにより定量的に評洒し, 六君子湯による症状改善奻果に

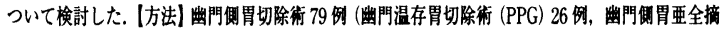
術 (ST) 53 例)を対象とした。同一患者に対して六君子湯 2 週間投与，2週間非投与によりそれ ぞれの期間について QOL を質問した. QOL は GSRS (Gastrointesinal Symptom Rating Scale) の 質問表に基づき定量的に評洒した。成績) 六君子湯非投与時 score は, PPG：ST で道流症状 $1.60: 2.56(p=0.001)$, 腹筹 $1.70: 1.87(p=0.377)$, 消化不良 $2.63: 2.20(p=0.071)$, 全消化管症 状 $2.12: 2.14(\mathrm{p}=0.946)$. 六君子湯投与時 score は, PPG : ST て逆流 $1.37: 1.71$, 䧗有 $1.34: 1.59$, 消化不良 $2.10 ： 1.76$, 全消化管症状 $1.73: 1.77$ で, 非投与時に比較してPPG で消化不良 $p=0.0541$, 全消化管症状 $p=0.017$ で, ST で道流症状 $p=0.0005$, 消化不良 $p=0.012$, 全消化管症状 $p=0.011$

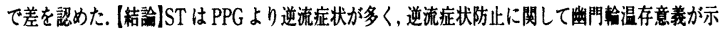
された，六君子湯による症状改善効果は闭辟でみられ，特にSTの逆流症状を改善させた。
PPS-3-077虚血性心疾患併存胃癌に対する胃切除例の害態と予後に วいて

池田義之, 大橋 学, 石川 卓, 内藤折也, 矢島和人, 田透 匡, 小杉伸一, 中川 悟, 神田達夫, 畠山勝義

(新潟大学第 1 外科)

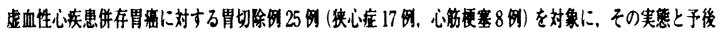

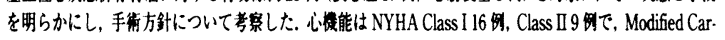

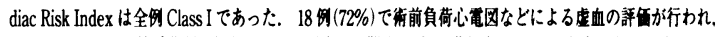

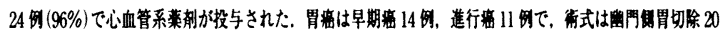

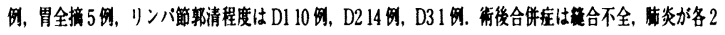

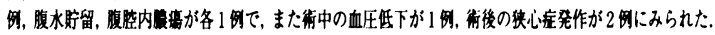

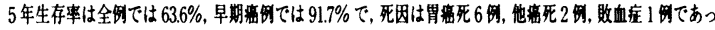

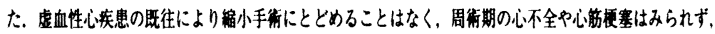

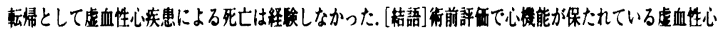

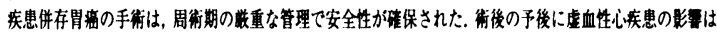
なく，胃繁に对しては根治性を落とすことなく手菜すべきであると考える。

PPS-3-078 胃癌術後のフォローアッブに関する検討 川村秀榯, 近藤征文, 岡田邦明, 石津宽之, 益子博幸, 秦庸壮, 植村一代, 㐘地一公, 横田良一, 後藤了一

(厚生連札幌厚生病院外科)

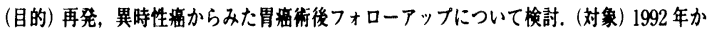
ら 1997 年の術後 5 年以内の消息不明例を除く 687 洌. (耛果) stage 別 5 生事は Ia か

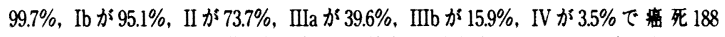

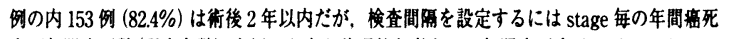

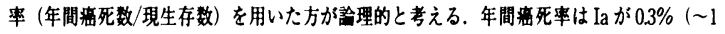
年), $0 \%$ ( $1 \sim 2$ 年), $0 \%$ ( $2 \sim 3$ 年), $0 \%$ ( $3 \sim 4$ 年), $0 \%$ ( $4 \sim 5$ 年), 同槏に Ib か $12.1,1.3$, $1.3,0$, II が $6.5,14.1,3.3,3.4,1.8$, IIIa が 20.8, 24.3, 18.5, 18.2, 0, IIIb が 21.1, 46.7,37.5, 40, 0. IV

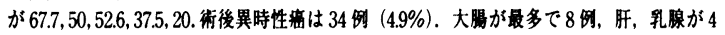

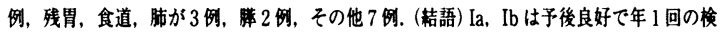

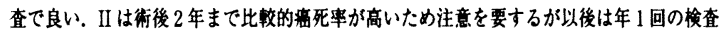

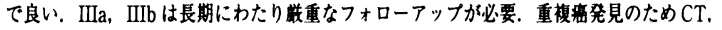
マーカーの他に，定期的な上下部内梘鏡検查や各がん㛟診を行う必要がある.

PPS-3-079 胃切除後の体成分組成による栄蓄評価 水谷 崇", 木山䕜郎", 奥田武志", 藤田逸郎", 吉行俊郎", 加藤俊二"，宮下正夫"，田尻 孝"，德永 昭"

(日本医科大学大学院脿器病態制御外科", 日本医科大学第二病院消化器 病センター2')

多周波インビータンス法により筋肉量，脂肪量なと体成分組成䁌定を行い，胃切除周符期およ

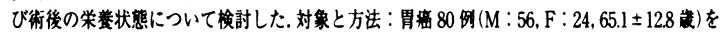

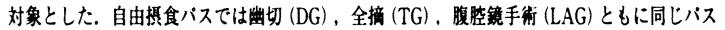

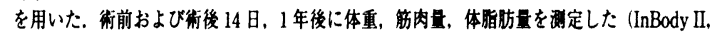

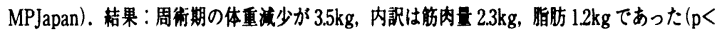

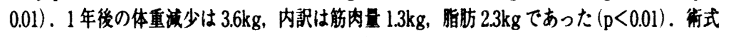
毎に比较すると, LAG0.7kg, DGl.8kgでは術前と差がないのに対し, TG13.2kgであった(pく

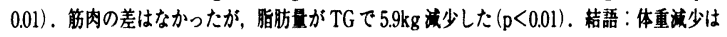

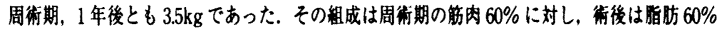

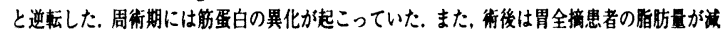

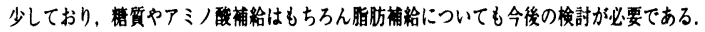

PPS-3-080 粘液形犋をもちいた胃早期低分化腺癌の術前悪性度診断 と臨床応用 蓝原龍介，持木彫人，中林利博，神山陽一，浅尾高行，桑野博行 (群馬大学第 1 外科)

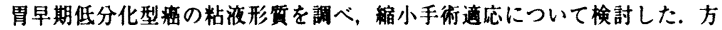
法：早期低分化癌 129 例の粘液 (胃型 ; 45M1, MUC6, 渴型 ; MUC2, CD10), MMP-7, $\beta$-catenin, p53, Ki-67 の免疫染色を施行した. 症例は, 印罢細胞㾔 (SIG：69) と, それ以外 (non-SIG：60) に分類した. 結果：1. non-SIGは

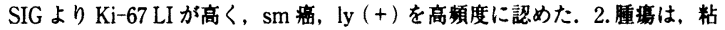
液の組み合わせで胃 $(\mathrm{G}: 54 \%)$, 胃腸 $(\mathrm{GI}: 40 \%)$, 晹 (I：2\%), 分類不能 $(\mathrm{U}: 4 \%)$ の 4 型に分類された. $3 . \mathrm{GI}$ 型は，他型より SIG. sm 戠, ly $(+)$, $\beta$-catenin の核内発現 ( $\beta$-NA) が高頖度であった. 4. 粘液形質と P53,および ki-67に相関は認めなかった. $5 . \mathrm{sm}$ 漫洞の独立因子として, non-SIG, GI 型, $\beta-\mathrm{NA} か ゙(\mathrm{P}<0.01)$, またりンバ管浸渥の独立因子として GI 型が多変量 解析にて選択された $(\mathrm{P}<0.05)$. 結諭 : 早期低分化型腺瘦の術前生検診断にお いて non-SIG, GI 型, $\beta$-NA 発現のない症例は縮小手術京応になりえる. 
PPS-3-081早期胃獭における再発危険因子と術後 follow-up につい ての検討

池田陽一, 岸原文明, 矢原瀿郎, 池尻公二, 才津秀樹, 朔 元則

(国立病院九州医療七ンター外科)

【目的】早期胃榣における術後再発危険因子について多変量解析を用い

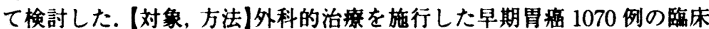
病理学的因子について検索した. 多変量解析には Cox regression 解析を 用いた.【結果】早期窝の再発率は $2.8 \%$ であり,再発形式としては血行性 転移，腹膜播種，リンパ節転移の順であった。再発危険因子は単変量解 析ではリンパ節転移，深達度、リンパ管侵隻，脈管侵祳および年齢であ ク，多変量解析ではリンバ節転移であった。リンパ節転移に関しては, 無再発 1040 例におけるリンパ節転移事が $6.9 \%$ であるのに対して, 再発 30 例では $60 \%$ に達した。また，リンバ節転移(ー)の早期胃㾔 976 例に おける再発例は $1.2 \%$ にすぎなかった.【まとめ)術後再発危険因子を考 㾇することは, 多数の早期胃癌症例を効事的に follow-up するためには 重要であると考えられた。

PPS-3-082 E-cadherin, $\boldsymbol{\beta}$-catenin 発現異常を指標とした早期胃癌の sm 浸潤, リンパ節転移予湘の検討

田中雅之，北島吉彦，佐藤清治，中房祐司，宮崎耕治

(佐賀大学一般・消化器外科)

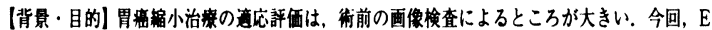
一 $\mathrm{cad}$ の発現異常と早期胃盘の壁進達度との関連を術前生检標本用いて角析し, 術前深達度診

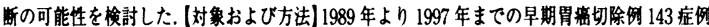

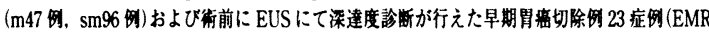

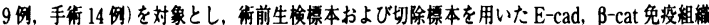
化学染色を行った，架色性の䛨便は正常上皮と同㥞に緗胞間に架色される場合のみを normal，

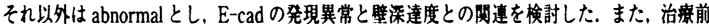

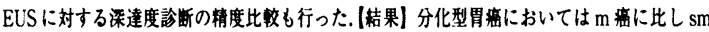

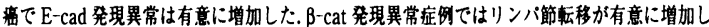

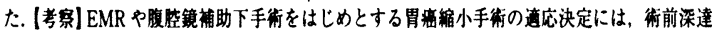

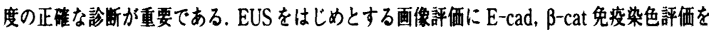
加えることにより，胃毒耤小手術の道底決定における精度向上が期侍される。

\section{PPS-3-083 表層拡大型胃癌症例の検討}

藤原省三, 野口㴊, 橋本剛, 武野慎佑, 和田伸介, 田中栄一, 川原克信

\section{(大分大学第 2 外科)}

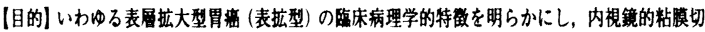

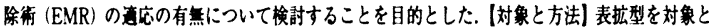

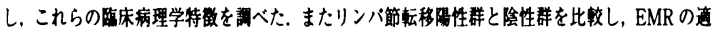

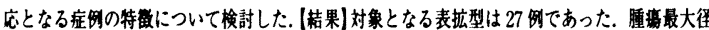

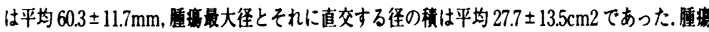

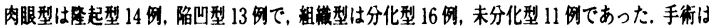

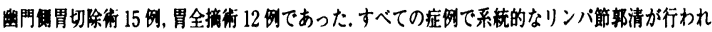

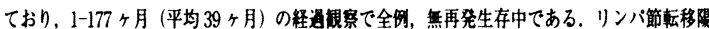
性群は院性群より有意にリンハ管侵赛が高度であったそその他の䧗床病理学的因子では有意差

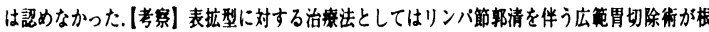

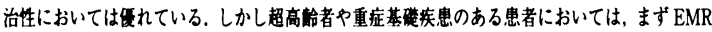

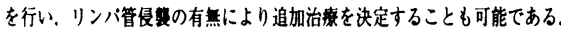

PPS-3-084 胃 M 痘症例における治療法の検討

太田 学", 今野弘之", 田中達郎", 神谷欣志", 馬場 恵",

近藤蜸司"，平松良浩"，菊地宽利"，山本真義"，中村 達"

(浜松医科大学第 2 外科", 浜松医科大学光学医塨診撩部 ${ }^{21}$ )

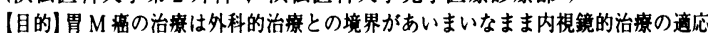

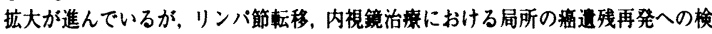
討が必要である. 【方法】胃 M 症症例 250 例について検討した. 【結果】(1) 外科的治

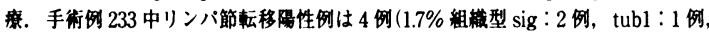

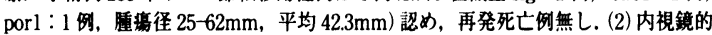
治㞠. 当科では内視镜敨治療として内視鏡的粘膜切除法 EMR, アルコンブラスマ レーザー治廉 (APC)，光線力学的治㩧 (PDT) を行っている。再発は 3 例 $(17.6 \%)$

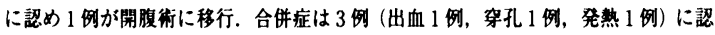

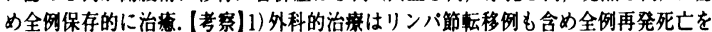

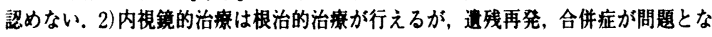

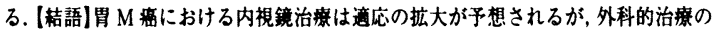

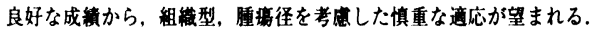

PPS-3-085 早期胃癌の組織型と Mucosal break を伴う逆流性食道炎 の関連

中村哲也", 吉田 昌", 熊井浩一郎 ${ }^{2}$, 細田シロシ"), 久保田哲朗", 大谷吉秀"，古川俊治"，才川義朗"，石川秀樹 ${ }^{3}$ ，北島政樹"

(慶應義熟大学一般・消化器外科"), 慶應義塾大学内視鏡センター2), 慶應 義熟大学救急医学 ${ }^{3}$ )

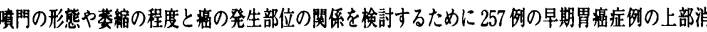
化管内梘鏡検查を検討した，逆流性食道炎は Los Angeles 分類で，食道裂孔へルニアは Keio Can-

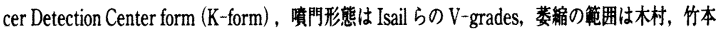

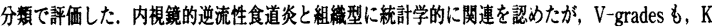
-form も組榙型との間に関連を記めず，嗔門部番と V-grades，K-form との関連も認めなかった。

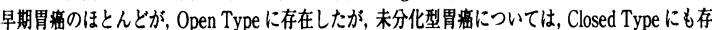

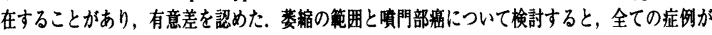
open type に存在していた. Mucosal breakを伴う逆流性食道炎は，娄樎の少ないClosed Type

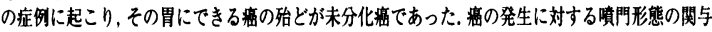

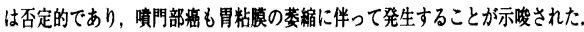

PPS-3-086 胃癌 $\mathrm{m}$ 癌で $7 \mathrm{~cm}$ 大のリンパ節転移さらに術後肝転移を 認めた 1 例 中䗁隆行"，柴田健一郎"，長谷場仁俊1), 谷口英樹"1, 中尾 丞", 高原 耕")

(日赤長崎原爆病院外科 ${ }^{1}$, 日赤長崎原爆病院病理 ${ }^{2}$ )

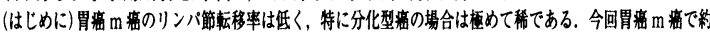

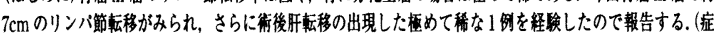

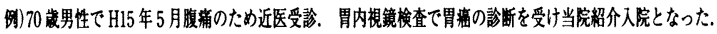

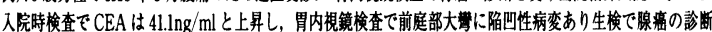

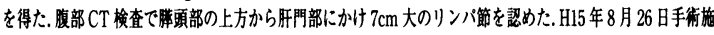

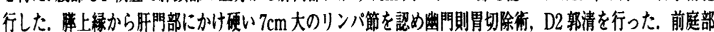

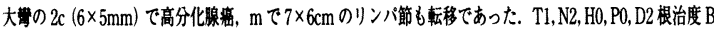

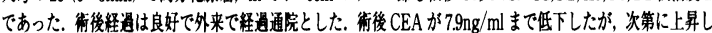

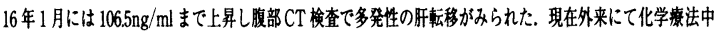

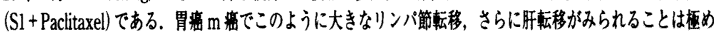

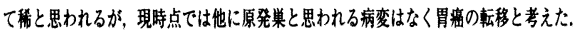

PPS-3-087 広沉な 2 群リンパ節転移を伴った胃粘膜内癌の一例 田村智章, 二見喜太郎, 永川祐二, 河原一雅, 東大二郎, 紙谷孝則, 関 克典, 有馬純孝

(福岡大学筑紫病院外科)

胃粘膜内整では一般にリンバ節転移の可能性は低いと認識されており，文献的にリンパ節 転移があった場合でもとのはとんどは1群りンバ節である.今回，大きさ $45 \times 42 \mathrm{~mm}$ の広 沉な 2 群リン八節転移を伴った IIc + IIIIの未分化型 $\mathrm{m}$ 癌を経呀したので報告する。症例は 43 才の女性. 上腹部蒲, 体重娍少を主訴に近医にて胃癌の診断を受け精查, 加療目的に当 院紹介となった，胃精查にて胃角部を中心とした Ic +III like advanced cancer と診断し， 2002 年 6 月 3 日に幽門僛胃部分切除術および 2 群リンバ節郭清を施行した。病理組織検査 結果は signet-ring cell carcinoma, 深達度は $\mathrm{m}, \mathrm{ly} 0, \mathrm{v} 0, \mathrm{INF} \alpha$ で open ulcer(UI IV)を伴っ ていた。リンパ節転移は No3 (1/8)，4d (3/7)，4sb (1/4)，6(2/10)，7(2/3)，9(1/2), $11 \mathrm{p}(1 / 6)$ に認めた $[11 / 46] .1$ 年 8 个月経過し，再発なく経過している．胃粘膜内㾂の自

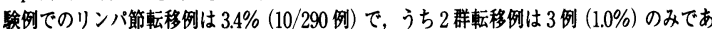
り，他の 2 例の 2 群転移は N $0.7 に 1$ ケのみであった. 胃粘膜内癌で 2 群リンパ節まで広沉 に転移した症例はきかめて稀であり，文献的考察を加え報告する。

PPS-3-088胃癌同時性肝転移に対する肝局所療法および動注化学療 法の検討

佐々木寛, 二宮基樹, 原野雅生，青木秀樹，小野田正，塩崎滋弘， 大野 聡，桧垣健二，小林直広，高倉範尚

(広島市立広島市民病院外科)

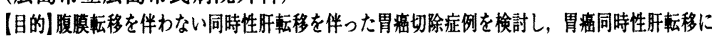

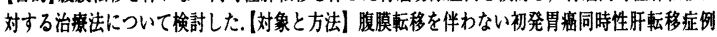
のうち胃切除が行われた20例を対象に, 肝局所治暴の有無, 肝動注の有無による生存事を比較

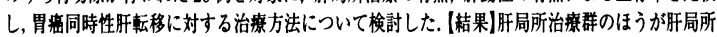

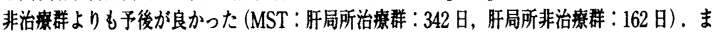
た，蟠注群は非動注群よりも予後の改善か証められた（MST：動注群：342 日，非動注群：189 日). 肝局所治窉群 11 㓩の検討では胿動注群のほうが非動注群より予後は良く(MST：動注

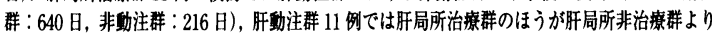

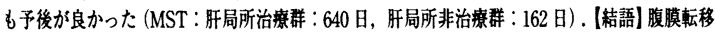
を伴わない胃要同時性肚転移症例では，胃切除とともに肝局所治療に加元術後補助化学療法と して動注化学撌法を併用することが予後の向上に結びっく可能性が示唆された。 
PPS-3-089 胃㿋肝転移例に対する肝動脈化学塞栓療法の経験 西島弘二"1, 湊屋 剛", 伊藤 博", 黑阪慶幸", 竹川 茂", 桐山正人 ${ }^{11}$ ，道場昭太郎"，小島靖彦"，小林昭彦"，斎藤泰雄 ${ }^{21}$ (国立金沢病院外科 ${ }^{1}$ ，国立金沢病院放射線科 ${ }^{21}$ )

（目的）胃癌肝転移症例に施行してきた肝動脈化学塞栓療法（TACE）の成縝 について報告する. (対象と方法) 胃癌手術症例のうち肝転移巣に対し TACE を施行した 6 例を対象とした. TACEに際し, 5-FU, mitomycin-C, adriamycin, lipiodol を併用した. (結果) TACE2 カ月後の評価ではPRが 1 例, NC が 2 例, PD が 3 例であった. NCの 2 例は TACE4 5 力月後に転移巣の增大を 認め, 追加 TACE を行った. PR の 1 例は, 占拠率 40\%に及ぶ異時性多発性䏕 転移に対しTACE を行った症例で, CR に近い状態を 2 年間維持し健在中であ る. 副作用として発熱, 軽度の肝機能異常を認めたが, 重篤なものはなかった。 $\mathrm{TACE}$ 施行例の 1 年生存率は $33.3 \%, 50 \%$ 生存期間は 8.8 力月であった. (結 語) 胃癌肝転移例に対する TACE は，重篤な副作用もなく安全に施行可能であ ク，著効例も経験した．更なる症例の蕃積と検討が必要であるが, TACE は, 胃癌肝転移に対する集学的治療の一端を担う可能性があると考えられた。

PPS-3-090 治癒切除術を施行した胃癌からの転移性肝癌に対するラ ジオフリークエンシー凝固療法

平田 勝1", 五藤 忠 ${ }^{2}$, 鈴木信親", 久富伸哉1", 片山原子", 川端英孝”，田中 弦"1, 田中 潔”

(JR 東京総合病院外科1", JR 東京総合病院消化器内科 ${ }^{21}$ )

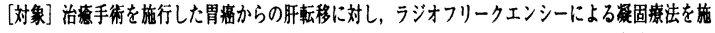

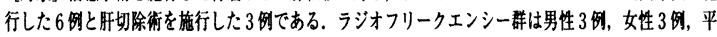

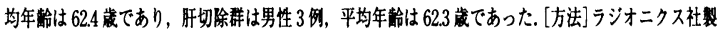
ラジオフリークエンシーを用い，針は cool tip $2 \mathrm{~cm}$ または $3 \mathrm{~cm}$ を用い，一回に6分間疑固を行った。 生存事 (Kaplan-Maier), 治察に伴う合併症, 入院期間についてラジオフリークエンシー群と肢切除群

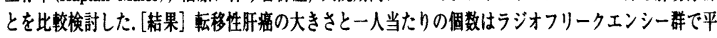
均 $4.7 \mathrm{~cm}, 1.8$ 個, 沏切除样で $5.2 \mathrm{~cm}, 2$ 個であった. 平均治数回数占よび平均入院期間は, ラジオフリー クエンシー群で 2 回, 9.0 日, 肪切除群で1 回, 33.7 日であった. 1 年生存害はラジオフリークエンシー

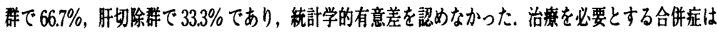

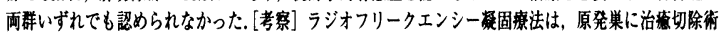

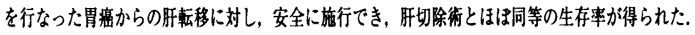

PPS-3-091 胃癌肝転移症例の検討

岡田俊次, 東風 貢, 寉田信行, 舟田知也, 藤井雅志, 高山忠利 (日本大学第 3 外科)

目的：胃㿋肝転移症例に対し，肝切除の意義を検討した. 方法：1991 年 201 年当院に て経験した胃㿋肝転移症例 50 例を肝切除群, 化学撩法群に分け retorospectiveに検討 した. 胃癌肝切除例は 15 例で男性 11 例女性 4 例であった. 肝転移数は, 単発が 11 例, 多発が 4 例であった。組織型は分化型 10 例，未分化型 5 例で，腹膜播種は 1 例に記めた。 手術は全例胃切除 (幽門側胃切除術 7 例, 胃全摘術 8 例) が行われ, 肝切除は拡大葉切 除 2 例, 葉切除 4 例, 区域切除 1 例, 部分切除 8 例であった。 化学療法群は 35 例で男 性 28 例女性 7 例であった. 肝転移数は単発 5 例, 多発が 30 例で組樴型は分化型 19 例, 未分化型 11 例その他 5 例であった. 胃切除が施行されたのは 11 例（幽門側胃切除術 8 例，胃全摘術 3 例）であった. 腹膜播種は 19 例に認め, 3 群以上のリンバ節転移を 12 例に認めた. 化学療法の効果は, $\mathrm{CR} 0$ 例, PR8 例, NC16 例, PD11 例であった. 結果： 単変量解析では, 腹膜播種の有無, 胃切除の有無, 化学寮法の効果の有無で有意差を認

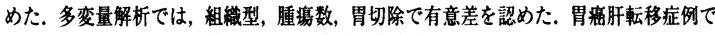
は, 肝転移切除群と化学療法群では生存率で有意差を認めなかった。

PPS-3-092 TS-1による胃癌肝転移の治療効果

東風 貢, 藤井雅志, 岡田俊次, 海賀照夫, 森下友起恵, 高橋 亨, 笠倉雄一, 高山忠利

(日本大学第 3 外科)

(目的) 胃旗肝転移例に TS-1 を含吉化学療法を施行, 以前の化学療法と予後 を retrospective に比較した. AFP 産生胃癌は除外した. [対象, 方法] TS-1 を含む Regimen で治療した 10 例（TS-1 群）と TS-1 を含まない治瘖群 32 例（対象群）を比較. TS- 1 群は TS- 1 単独 2 例 TS-1 + CDDP か 8 例, 対象 群は FLEP 療法 15 例, $5 \mathrm{FU}+\mathrm{MMC} 5$ 例, $5 \mathrm{FU}+\mathrm{CDDP} 5$ 例, $5 \mathrm{FU}$ 単独 CPT 11 単独がそれぞれ 1 例, その他 5 例. 生存は Kaplan-Meier 法で比較. [結果〕 TS-1 群の平均年齢 69.9 歳, 対象群 61.3 歳. 男女比 TS- 1 群 $8: 2$, 対象群は $26: 6$. 肝転移は H1 が TS-1 治㞠群で 4 例 (40\%), 対象群で 10 例 (31.3\%) で あった. TS-1 群の奏効率は PR6 例 $(60 \%)$, 対象群 PR6 例 (18.8\%) TS-1 群の MST は 15 ヶ月, 対象群は 5 ヶ月で $\mathrm{p}=0.006$ で有意に TS- 1 群の予後良 好. 多変量解析で TS-1 治療は治療効果の次に予後改善因子に選択された. 〔結語〕胃癌肝転移例に TS-1 を含む化学療法で予後の改善が期待できる.
PPS-3-093 胃癌における骨链微小転移検出の隔床的意義 藤田康喜", 寺島雅典"，神崎菁雄”，橙村省吾"，星野美加"， 大谷 聡"，松山真一"，星野 豊"，木暮道彦"，後藤满一" (福島県立医科大学第 1 外科"，功病院外科 ${ }^{21}$ )

【目的】胃癌の骨噵淮中の微小転移の有無に関して, real-time RT-PCR 法を 用いて CEA, CK19, CK20の mRNA を定量的に測定し，侮床的意義について 検討する.【方法】对象は2000 年 11 月から 2003 年 4 月に当科で手術した胃盘 切除症例 65 例. 手術時, 骨噵液を胸骨より探取, total RNA を抽出. TaqMan PCR 法にて, CEA，CK19，CK20の mRNA を定量的に测定，内部標隼として 測定したGAPDH mRNA 発現量で標涑化した. (結果】MKN45を用て CEA, CK19,CK20 について 1×107個のリンバ球中 1 個の瘏細胞まで検出可能な点 を検出限界として cut-off 值を定め, 骨跹微小転移の有無を判定した. 对象 63 例中, CEA, CK19, CK20の mRNA か淂性と判定されたものは1例 $(1.6 \%) の$ みで T4, N3, M0, H0, P1, StegeIV で術後 6 ヶ月後に死亡している.【結語】胃 癌骨戟液中の微小転移の頻度は低く，極度の進行例でのみ認められた。胃瘖に おいて骨蹎中の徽小転移を検出する意義は乏しいものと思われた。

PPS-3-094 NK4 による腹膜転移抑制と機序

藤原 斉, 却田 健, 天池 寿, 稲田 聡, 高鴄一博, 阿辻清人, 吉村 衛, 阪倉長平, 萩原明於, 山岸久一 (京都府立医科大学消化器外科)

目的】れれで我々は，NK4 発現による腹膜転移抑制効果を, NK4 発現了

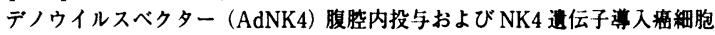
移植モデルを用いて明らかにした. 今回, その機序についての新たな知見を

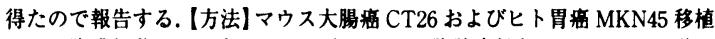
による腹膜転移モデルを用いた，1）AdNK4 腹㓐内投与マウスにGFP 発現 練胞を移植し，大網乳斑に対する㾝細胞浸润性をFACSにより評価した，2） 親細胞およびNK4 発現細胞における転移関連遗伝子群の発現をDNA microarray を用いて比較した．また，細胞外基领に対する接着性を adhesion assayにより比較した.【結果】1)大網乳斑に対する繰細胞浸洞は，NK4 発現 により移植後早期より抑制された，2）NK4 発現により，特定の接着分子の 発現減弱と, HGF 存在下の特定の基質に対する接着抑制が得られた。 [結論】 NK4による接着浸洞抑制を介した腹膜転移抑制機序を明らかにした。

PPS-3-095 FGF receptor2 阻害郕によるスキルス胃癌腹膜播種性転 移の分子標的治療

中村和憲"，八代正和"，天道正成"，山田靖哉"，澤田鉄二"， 大平雅一"，西口幸雄"，加藤保之"，三答史"，平川弘聖' (大阪市立大学腫场外科", キリンビール医菜探索研究所 ${ }^{2}$ )

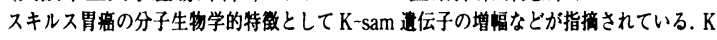
-sam 逢伝子は, FGF-R と相同性を有している. FGF-Rのなかでも FGF-R2 は重要で,

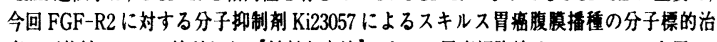

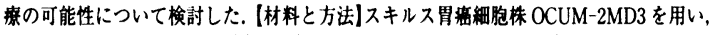

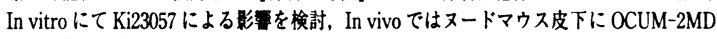

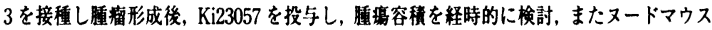

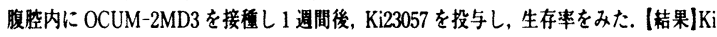
23057 は OCUM-2MD3にはIn vitro にて增殖抑制作用を示し，またヌードマウス皮下移

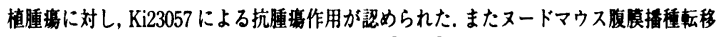
モデルに対しても生存事の延長が認められた. [格詥] FGF-R2に対する分子抑制剂 Ki

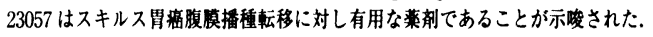

\section{PPS-3-096 残胃の早期癌に対する内視鏡的粘膜切除術（EMR）の検} 証

小野田尚佳, 意城 圭, 山下好人, 山田靖哉, 西口幸雄, 加藤保之, 已野 綾, 大平雅一, 石川哲郎, 平川弘聖

(大阪市立大学腫場外科)

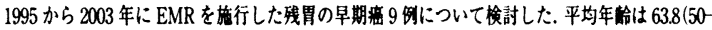

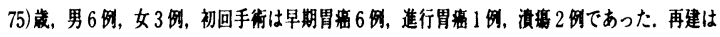

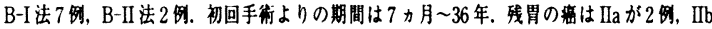

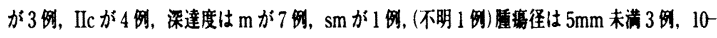
$20 \mathrm{~mm} 4$ 例， $20 \mathrm{~mm}$ 以上 1 闻であった. 6 用が一括切除され, $8 \mathrm{~mm}$ 大の Ila が 2 分割, $12 \mathrm{~mm}$

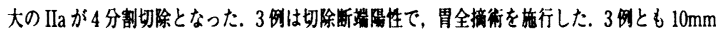

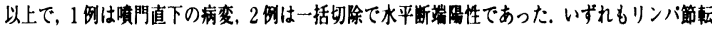

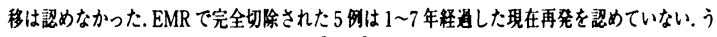

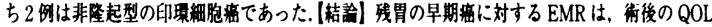

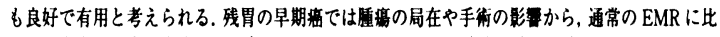

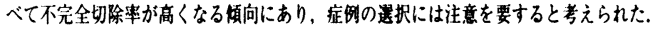


PPS-3-097 胃粘膜内䟧に対する内視鏡的粘膜切除の成績 瀧藤克也, 有井一雄, 中村公紀, 中谷佳弘, 岩橋諴, 山上裕機 (和歌山県立医科大学第 2 外科)

1985 年より長径 $2 \mathrm{~cm}$ 以下の潰場形成のない分化型の胃粘膜内瘦 178 例に対して内視鏡 的粘膜切除 (EMR) を施行したので，その成績について評価した. (方法】2チャンネル法

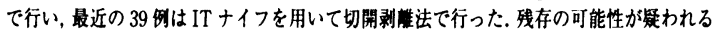

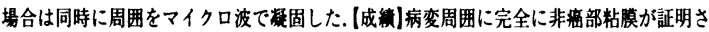

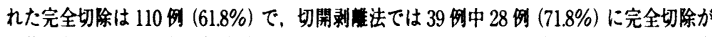

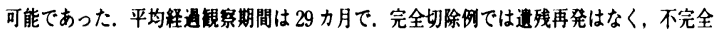
切除 68 例中 9 湖 (13.2\%)に逢残再発を認め，全例 1 年 6 力月以内に発見された。このう

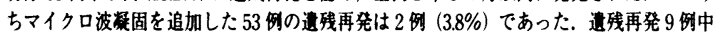
4 例は再度 EMR を行い，その後の平均释週期間は 28 力告の再発は認めていない. sm 瘦 12 例 $(6.7 \%)$ のうち sm slight の 9 例は镜察を行い, 平均 23.4 力月の経過锶察中に再発 はない. 合併症は出血により聚急手術を要した1例（0.6\%）のみで，穿孔は2例（1.1\%)

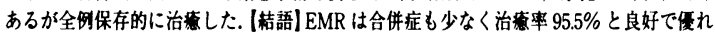
た治港法である．また，不完全切除例に対するマイク口波凝固は有用であった。

PPS-3-098 早期胃病に対する EMRの現状と問題点 福富 峪"1, 清家和裕" 宮崎 勝

(千葉大学大学院腿器制御外科学 ${ }^{11}$, 千葉県がんセンター消化器外科 ${ }^{21}$ ) EMR 范行後 2 年以上経通锶察された症例において对象胃整の進行により死亡した症例は認めて いない.(EMR 後の病理評值にて根治不能として追加外科治暴が行われた症例は11 湖 (11.8\%))

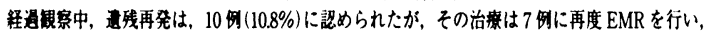

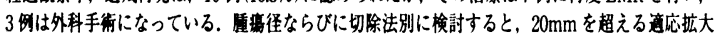

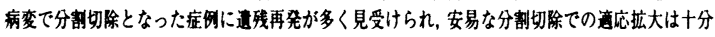
注意する必要があると思われた，末分化带のEMR 症例は3网 (3.2\%)で，うち1例は 2 年後に 再発を認め外科手街になっている.手街に至った症例は分割切除であり，かつECjunction 直下で

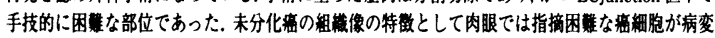

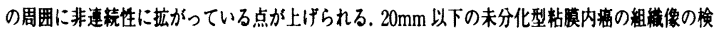

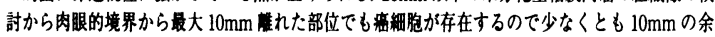

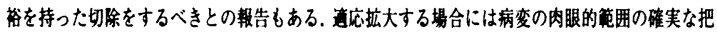
提, 非連筑性水平進展を考㥁した切除籍囲の設定, などが肝要であると思われた。

PPS-3-099 内視鏡的胃粘膜術後の横隔膜ヘルニアの1例 小泉博志, 村上 望, 伴登宏行, 森田克哉, 吉野裕司, 藤森英希, 俵矢香苗, 中田浩一, 小竹優筑, 山田哲司

(石川県立中央病院一般消化器外科)

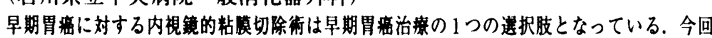

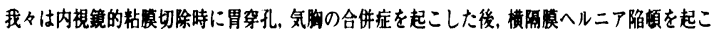

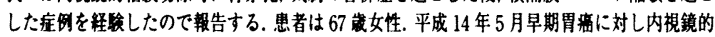

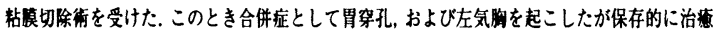
している. 平成 15 年 12 月 1 日より左季肋部莆出現し，2 日近医受診. 3 日に胃内視鏡検查施

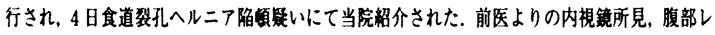

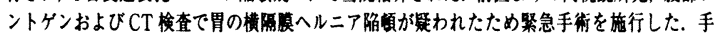
街所見では，前回の胃盘病変部に対応する左国横隔璄にヘルニア門があり，底部から体部まで

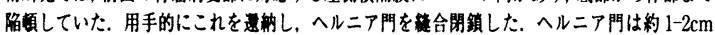
大であった，胃艒の内梘鏡的粘膜切除術の合併症として，出血，穿孔などがあげられているが，

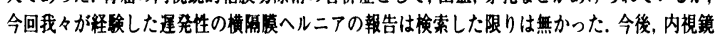
的粘暮切除術の症湖か增加して行くとこのような合併症もあり得るので注意が必要である.

PPS-3-100 Day Surgery System における経皮的内視鏡下胃瘄造設 術一当施設の試み, 問題点と今後の展望

角尾英男"，林 臬治"，木全秀人"，秋山清次 ${ }^{21}$, 中尾昭公"

(国立東名古屋病院外科"，名古屋大学大学院病態制御外科 ${ }^{2}$ )

経皮的内梘鏡下胃接造設術 Percutaneous Endoscopic Gastrostomy (PEG)を年間 40-50 症例程実施している。最近は他施設から PEG 目的での紹介受診も增加した. 問題点, 利 益と手術手技, 術後管理の工夫, クリニカルバス等も少々文献的考察も加六報告する. 【方法】ほは全貌 pull 法にて安全に留置や術後管理が可能なバードファストラック PEG カテーテルを第一選択とし, 重第な合併症はない. [問題点】ミタソラムによる鎮静の際, 呼吸管理の準㒂をして行う．腹部手術特に胃切除術の既往，横行結晹拡張，肝腫，V-P シャント留置, 腹水例等も慎重何とする. 造設後も逆流性誤監性肺炎の risk は常に念頭 に置く. 合併症は横行䊅渴穿刺, 肝外㑡区域穿刺が各 1 例あったが情孔安定後再造設を 行った内部バンバー镜落と内部バンバー埋没症傽群をワンステップ゙タン型使用例に

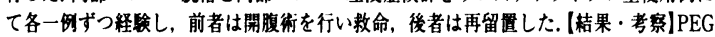

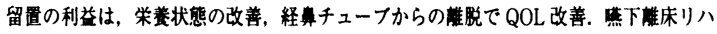
ビリにも利益があり，在宅管理も可能で，今後更に件数は增加すると考えられる.
PPS-3-101一括切除を目指したITナイフによる内視鏡的胃粘膜切 除術の検討：分割切除との比較

衛藤㓮, 松井容子, 富寺々盛学, 泉 公一, 白下英史, 石川浩一, 猪股雅史, 白石憲男, 北野正剛 (大分大学第 1 外科)

【目的】ITナイフ法による一括切除と，Strip Biopsy 法あるいはCap 法による計画的 分割切除の治療成績を比較し, IT ナイフ法の利点と問題点を検討した.【方法】 EMR を施行した 49 例，55病変を対象に, IT ナイフ (IT) 法 (23 病変) と, Strip Biopsy (SB) 法 (25 病変) およびCap (C) 法 (7 病変) に分けて比較した.【成績】平均切除 腫鸤径 $(\mathrm{mm})$ は IT $/ \mathrm{SB} / \mathrm{C}=15 / 11 / 12$, 平均分割切除回数は IT $/ \mathrm{SB} / \mathrm{C}=1.1 / 3.4 / 3.7$ で あった. 治痖切除 (EA) 率 (\%) はIT $/ \mathrm{SB} / \mathrm{C}=91 / 42 / 43$ であった. 偶発症はIT 法で 穿孔 2 例, SB 法で出血 1 例を認め, 穿孔 2 例は体上部症例, UL $(+)$ 症例であった. 平均施行時間 (分) は IT $/ \mathrm{SB} / \mathrm{C}=80 / 35 / 33$ であった. 再発率 (\%) は IT $/ \mathrm{SB} / \mathrm{C}=0 / 4$ / 14 であり, EC 例で再発例が多かった. (結論】IT ナイフ法を用いた一括切除により, 切除後の正確な組織学的評価が可能になった。体上部症例, UL $(+)$ 症例ではIT+イ フによる偶発症発生の危険があり，今後さらに手技上の工夫が必要と思われた.

PPS-3-102 当院における EMR 後手術を要した胃瘦症例の検討 須藤日出男 ${ }^{11}$, 高木 融 ${ }^{11}$, 伊藤一成 ${ }^{11}$, 星野澄人 ${ }^{1)}$, 遠藤光史 ${ }^{11}$, 铇田博美 ${ }^{1,}$, 向出将人 ${ }^{1}$, 土田明彦", 青木達哉 ${ }^{11}$, 河合 隆 ${ }^{2}$ ) (東京医科大学第 3 外科 ${ }^{11}$, 東京医科大学内視鏡センター ${ }^{21}$ )

目的, 胃嘴 EMR 後に胃切除術を施行した症例の臨床病理学的検討を行った. 対象, 1995

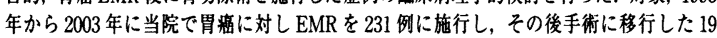
例. 粘果, 手術までの EMR 回数は 1 回から 6 回で平均 1.9 回, EMR 標本結果による手術 移行例が 14 例, EMR 後の経過観察中にEMR 適応外の病変が発見された症例が 4 例で あった. 手術移行例のうち一括切除が 8 例, 分割が 6 例であった. 手術を要した理由とし ては, 垂直断端陽性と粘膜下層浸潤例が多かった，手術摘出標本中に癌細胞を認めた症例 は 2 例あり、リンパ節転移を認めた症例はなかった. 経過観察中の適応外病変発見例のう ち透残再発が 1 例，他病変出現が 3 症例あり，2例に 2 群リンパ節転移を認めた。 いずれ もEMR を繰り返した症例であった. まとめ, EMR の病理結果でEMR 適応外症例に対し ては，胃癌治療のガイドラインに準じた追加治療が必要であり，EMR 後の経過観察にお いて, 遗残・再発だけではなく多発病変に留意した内視鏡検查と,転移検索のための腹部 CT や腹部超音波検査を追加した慎重なフォローアッブが必要であると考えられる.

PPS-3-103 T1 胃癌における EMR 適応拡大の検討 吉田卓義, 清崎浩一, 丸岡秀範, 斎藤正昭, 小西文雄 (自治医科大学大宮医療センター外科)

方法：T1 胃瘦手術症例 M 癌 268 例 SM 㿋 264 例を対象に, 病理組織学的観点加 EMR 拡大の検討をおこなった，結果：M癌では，3例 $(1.1 \%)$ に転移を認めた。すべて肉眼形態 が陥凹型で, 組織型はいずれも ulをともなった低分化型で，大きさはすべて $30 \mathrm{~mm}$ 以上の もであった．高分化型では大きさ，形態に関係なく転移は認めなかった，SM1 では $5 / 60$ 例 $(8.3 \%)$ に転移を認めた。低分化型の転移は $4 / 16$ 例（25\%) で，高分化型では $1 / 39$ 例 (2.5\%)であった，分化型でかつ隆起型のものでは大きさに関係なく転移は認めなかった. SM2 では 204 例中 42 例 (20.5\%) に転移を認め，そのうち 15 例 (35.7\%)に $\mathrm{N} 2$ 転移を認め た. SM2 におけるリンパ節転移は，低分化型で $22 / 56$ 例 $(39.2 \%)$ ，高分化型で 20/106例 (18.8\%)の転移を認めた. 肉眼形態によるリンパ節転移に差は認めなかった. 考案：ulを伴 わない M 癌ではリンパ節転移を認めず, EMRの適応と考えられた。 ul を伴う症例では, 未 分化藻や $30 \mathrm{~mm}$ 以上ものを除外すればEMRの可能性が示唆された. SM1 では低分化型, 陥 凹型の1例に N2： No7への転移が認められ, リンバ節郭清を伴う治療が必要と考えられる が, 分化型で隆起型のものでは転移を認めず, EMR 暗応拡大の可能性が示唆された.

PPS-3-104 胃㿋の幽門側胃切除術に対するクリニカルパスの評価 中野泰治, 宇佐美和夫, 上繁宣雄, 菅谷純一, 小坂健夫, 高島茂樹 (金沢医科大学一般消化器外科)

従来, 幽門側胃切除術後の管理は個々の担当医の方針でおこなわれていたが,クリニ カルパスを作成し, 術前術後管理を標準化する試みをおこなった. 対象と方法：平成 15 年 4 月より平成 16 年 2 月までにクリニカルパスを適用し幽門側胃切除をおこ なった 23 例を対象にした (パスダループ). また，クリニカルパスを適用以前の 13 例 (コントロールタループ) と比較した. 入院期間，食事開始時期，抗生剤点滴の投 与期間などについて検討した. 結果 : 術後入院期間はパスグループで平均 $23.7+/-$ 6.0 日, コントロールグループで $27.8+/-4.5$ 日であった $(\mathrm{p}<0.05)$. 食事開始日は術 後平均 $4.7+/-1.7$ 日目と $6.7+/-1.6$ 日目 $(\mathrm{p}<0.01)$, 胃管抜去は平均 $2.1+/-1.2$ 日目と $3.6+/-1.6$ 日目 $(\mathrm{p}<0.01)$, 抗生剤の投与期間は平均 $3.7+/-0.9$ 日間と $5.9+/-1.9$ 日間であった $(\mathrm{p}<0.01)$. 結語：幽門側胃切除症例に対するクリニカルパ スは術後の経過を標準化し, 入院期間の短縮, および薬脷投与や栄養管理を画一化す ることが可能であった．また，患者を中心に医療スタッフが情報を共有化すること で, 各スタッフと患者とのコミュニケーションが增し, 信頼関係が向上した. 
PPS-3-105幽門側胃切除における術後在院日数10日を実現した Clinical Path 効果

後藤田直人, 木下 平, 小西 大, 中郡聡夫, 高橋進一郎,

伊藤雅昭, 杉藤正典, 斉藤典男

(国立がんセンター東病院消化器外科)

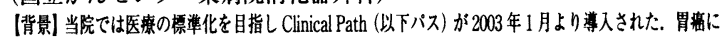
対しても全ての術式に対しパスを作成，2002年10月加3个月の試行期間をおき2003年1月より正式

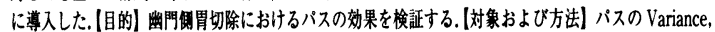
Outcomeの解析については2003年1月〜12月までを解析の対象としパス導入以前と比较㛟討も行った。

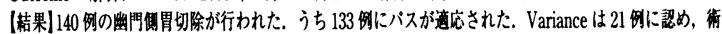

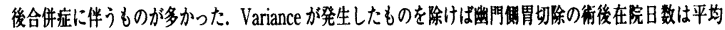

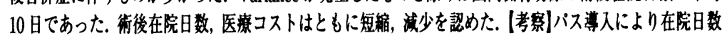

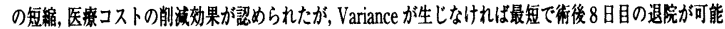

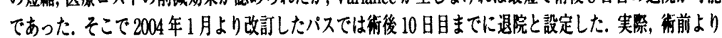

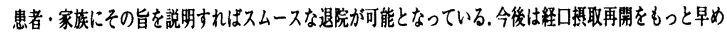

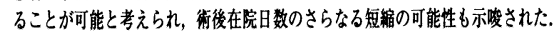

PPS-3-106 胃癌パスのバリアンス分析および病棟パスチーム会によ るパスの変化

若月俊郎, 豊田暢彦, 野坂仁愛, 竹林正孝, 鎌迫 陽, 谷田 理 (山除労災病院外科)

(目的) 胃癌パス中心にパス内容の経時的変化を詶べること. (対象と方法) 1999 年から現在ま での病棟チーム会によるバス内容の変化について满べた，次に胃缯バスにおいてパス前, パス 後, パス改定後における各種医療行為のバリアンス分析を行い，合併症頪度なとを調べハス改 定のエビデンスとした（結果) 1999 年ラパコレパスを導入し，月に 1 回医師, 看譩師でチーム 会を始めた. 2001 年から胃癌を含め 14 種類のパスを開始した. 栄養, 化学撩法などの問題が 生じ 2002 年から薬郕師，栄盖士，検査も参加しチーム医燎が進んできた，2003年バスは 19 種類に增え，入院診療計面書とパスを合体し，一部の疾患では点滴，菜郕の統一を图った，胃

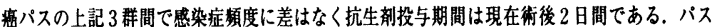
開始後点滴 7 日間, 食事開始 4 日目, ドレーン抜去 4 か 5 日目と早くなっているが合併症頃度 に差は認めず。硬麻抜去は 2 日目としていたが痛及が强く 4 日目としたが, 変化なく 2 日目に

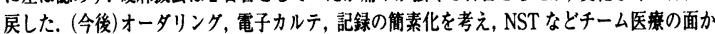
らとバリアンス分析に基づいて薬郕，点滴の統一化などが必要と考える。

PPS-3-107 胃切除胃全摘除術及び腸切除術におけるクリニカルパス を用いた在院日数短縮の試み

服部浩次, 岩田 宏, 内藤明広, 横山智輝, 吉本信保, 川原勝彦 (名古屋共立病院外科)

【目的】消化器外科手術症例の主に飲水開始時期と段陼食を見直し，胃切除・胃全摘除術及ひ渴 切除術のクリニカルパスを改訂し, 改訂前と比较榆討した。対象は 2003 年度に当院にて, 胃切 除・胃全摘除術を受けた改訂前 14 例，後 10 例，渴切除街を受けた改訂前 30 例，後 21 例である。 【改訂のポイント飲水開始時期：胃切除・胃全摘除術は排ガスがあれはUGIを行い開始する。 晹切除術では排ガスがあれば開始する。翌日より段階食を開始し，胃切除・胃全摘除術は，流動

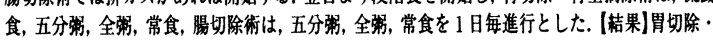
胃全摘除術の看水開始までの期間は，改訂前が 6.6 日，後が 3.2 日. 埴水開始から䢙院までの期 間は 16.1 日と 6.5 日. 術後在院日数は 22.7 日と 9.7 日. 改訂後症例でハリアンス症例は 2 例て あった。渴切除術の飲水開始までの期間は，改訂前が 6.0 日，後が 32 日であった。钦水開始か ら退院までの期間は 13.9 日と 6.3 日, 術後在院日数は 19.9 日と 9.5 日で, 改訂後症例て飲水開始 が荤れた症例は 4 例で，退院が荤れた症例は 2 例であった，改訂後に合併症俚增加していなかっ た.考察]パス改訂による在院日数短維の効果は，期待以上であった。

PPS-3-108 胃切除術におけるクリニカルパスの有用性と経口撕取ス ケジュールの改善

辻仲利政, 平尾素宏, 藤谷和正, 三宅正和, 益澤 徹, 日浦裕一郎 (国立病院大阪医療センター)

目的)胃切除術後管理改善の踟休研究の手段としてクリニカルバスを使用し, 術後経口提 取スケジュールの改善を得たのでその結果を報告する，方法）遠位㑡胃切除を受けた stagel 胃癌患者において，従来の 6PODからの段陼食による栄養管理を受けた 50 名(CR 群) と $1 \mathrm{POD}$ から飲水, $2 \mathrm{POD}$ から流動食, その後患者の要求による固形食スケジュール を受けた53名 (PC 群) の術後烸床指標をパスを用いて比較した，次に，PC 群での中央 值であった $1 \mathrm{POD}$ 飲水, 2POD 流動, 6POD 固形食のスケジュールをすべての stage の胃

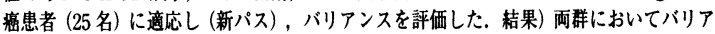
ンスの発生頻度 (34VS30\%)に差がなかった. 術後在院日数, 術後流動開始日, 固形食閉 始日はPCで有意に短縮した，また，退院時での体重娍少はPCで少ない煩向を示した。 10PODにおけるエネルギー摄取量はPC で有意に多かった。新バスでも安全性に問題な かったが，患者要因バリアンスが增加した。結論)早期経口摄取スケジュールは術後在院 日数と体重娍少を改善した，胃癌の stageに関らず早期経口提食は可能である。
PPS-3-109 上部消化管穿孔保存的治撩の電子クリニカルバス (CP) 運用上の安全性をいかに確保するか？

飯島正平, 加藤揵志, 辻江正樹, 大島 聡, 半田理雄, 直居靖人, 山本 毛, 黒川英司, 吉川宣輝

(箕面市立病院外科)

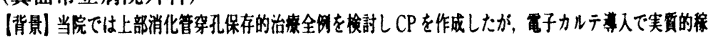

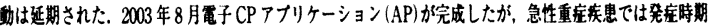

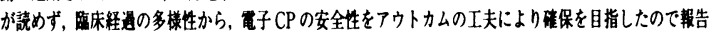

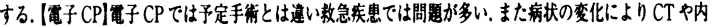

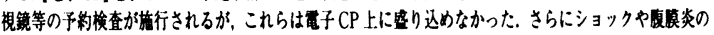

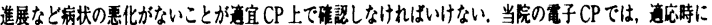

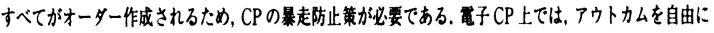

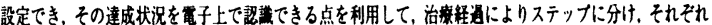

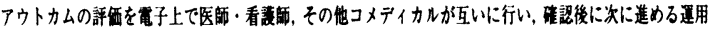

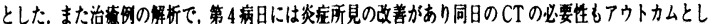

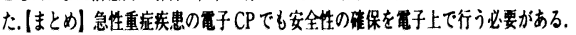

PPS-3-110 十二指腸溃癔穿孔症例に対するクリニカルパスの適応 千須和寿直，大森敏弘，田内克典，添田純平，小田切笵晃，

岸本浩史，有賀浩子，河西 秀，小松 誠，小池秀夫 (相澤病院消化器外科)

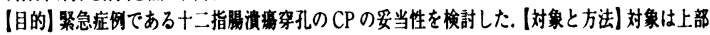

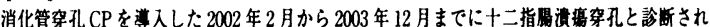

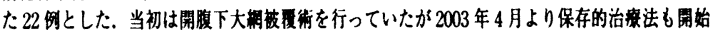

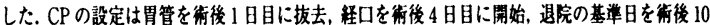

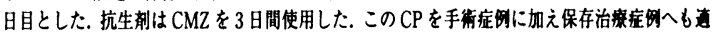

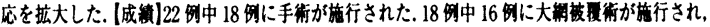

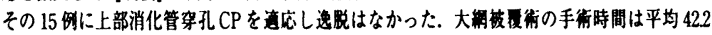
分，入院期間は平均 13.6 日（中央值 10 日）であった。保存的治竞を行ったのは 5 亿て，1用は

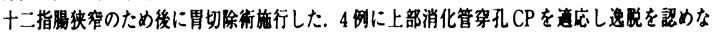

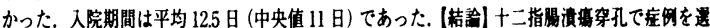

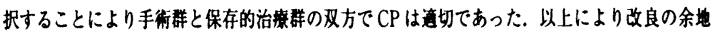

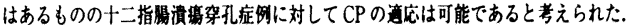

PPS-3-111 胃癌治療ガイドラインの解説書に対する患者㑡の意誈 小船戸康英, 関川浩司, 伊藤, 岩舘 学, 佐久間浩, 大木進司, 畠山優一，小山善久，井上典夫，竹之下諴一

(福島県立医科大学第 2 外科)

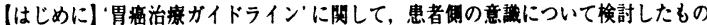

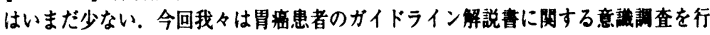
い，本ガイドライン解説書の意義について检討を行った．胃(対象および方法l2001

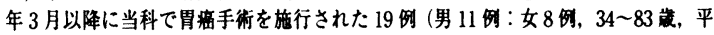

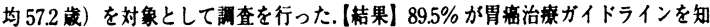
らなかったと答えた。 また手術前に解説春を㜔みたかったと答えた方は $100 \%$ で あった【考察】今回の堣查からガイドラインの解説書は患者佃にはあまり知られて いない事がかかった一方ではすべての患者が術前に読みたかったと答えておりここ

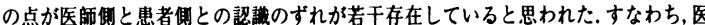
療者は癌の病気や転移などの説明はかえって術前の患者觔の精神状態を不安定にさ せるのではとの考えから皘極的には利用していなかった煩向にある. 今後は本春の 患者様への啓蒙と皘極的な利用に努めていかねばならないと思われた。

PPS-3-112 リンバ節転移および再発形式からみたSM 胃瘭に对する 胃瘦治㞠ガイドラインの問題点

鈴木恵史, 諸原浩二, 山崎公靖, 田鴄勇介, 長山裕之, 高村光一, 嘉悦 勉, 河村正敏，草野满夫

(昭和大学一般消化器外科)

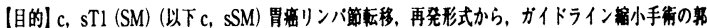

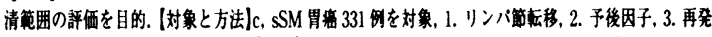

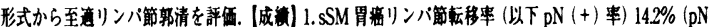
$112.1 \%, \mathrm{pN} 22.1 \%), \mathrm{pN} 2$ 部位位 $\mathrm{N} 0.7,8 \mathrm{a}$ のみ. $\mathrm{sN0}(\mathrm{n}=247)(\mathrm{n}=247)$ では分化型, 未分化型の $\mathrm{pN}$

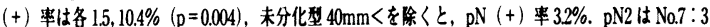

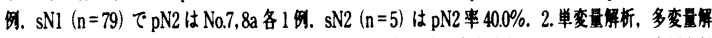

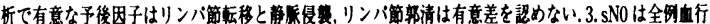

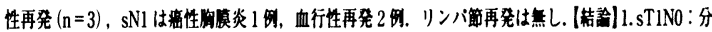

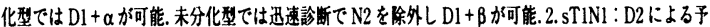

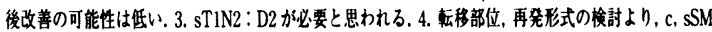

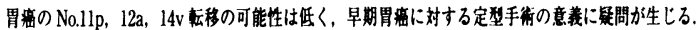


PPS-3-113 胍症肝炎を契機に診断された右側特発性食道破裂の 1 治 療経雅

津村裕昭"，市川 徹"，香河哲也"，日野裕史"，村上義明"

末田泰二郎

(広島市立舟入病院外科"，広島大学第 1 外科 ${ }^{2}$ )

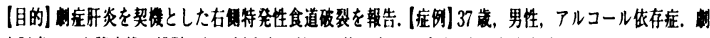

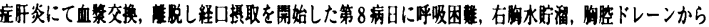

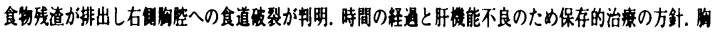

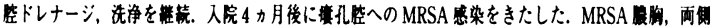

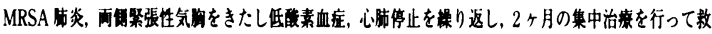

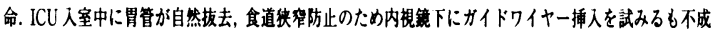

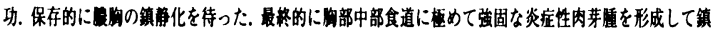

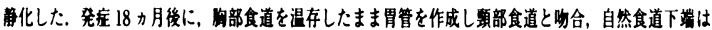
Roux-Y

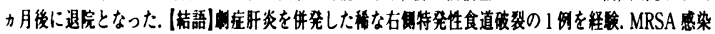

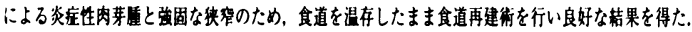

\section{PPS-3-114 特発性食道破裂 8 例の検討}

桑原史郎，山崎俊幸，大谷哲也，片柳惷雄，山本睦生，余藤英樹 (新淣市民病院外科)

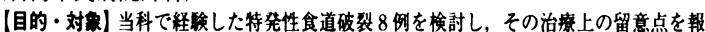

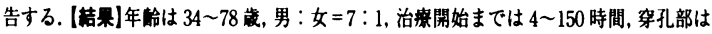

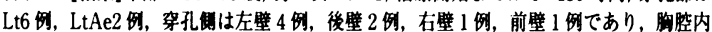

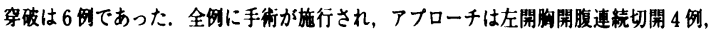

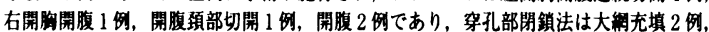

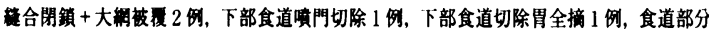

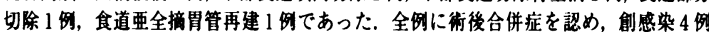

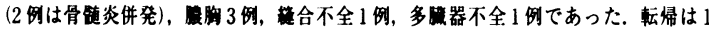

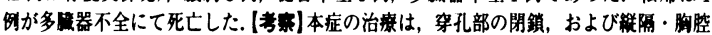
のドレナージである. 前者に関しては大成等の応用が有用と思われ，後者に関しては十

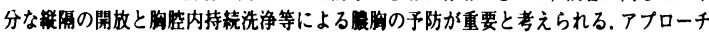

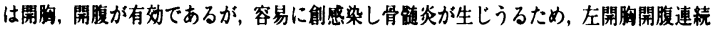
切閙よりも助骨切断を必要としない左肋間後閉方開胸・開腹が望ましいと思われた。

PPS-3-115 胃底部綎着術が有用であった特発性食道破裂の 2 例 宮本英雄，渡辺大樹，小林宣隆，沖田浩一，草間 律，藤森芳郎， 山岸喜代文, 西村博行

(厚生連北信淞合㧫院外科)

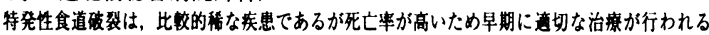

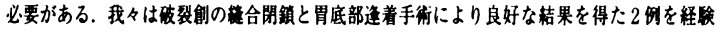

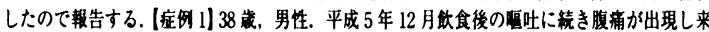

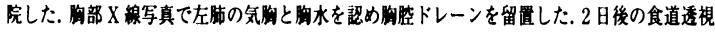

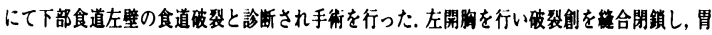

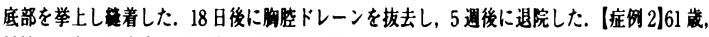

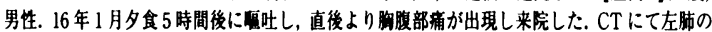

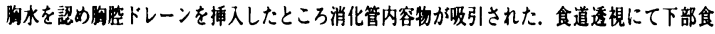

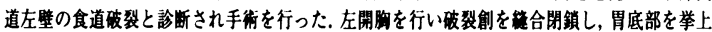

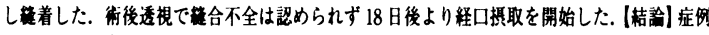

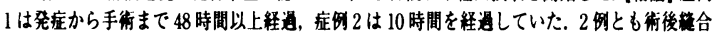

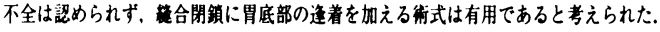

PPS-3-116䣽床経過が対照的であった特発性食道破裂（穿孔）の 2 例

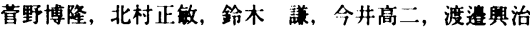
(米沢市立病院外科)

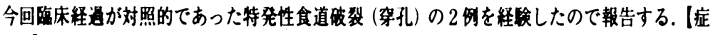

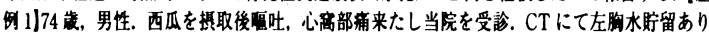

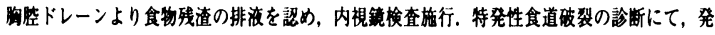

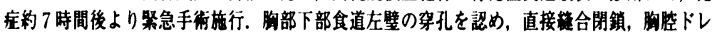

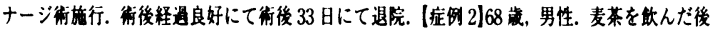

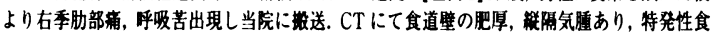

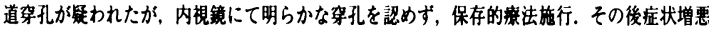

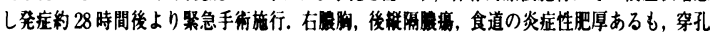

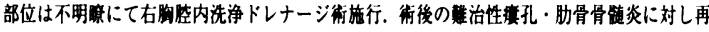

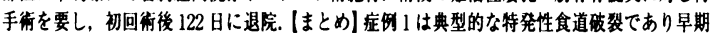

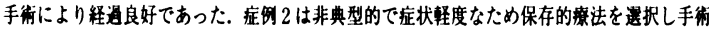

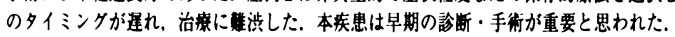

PPS-3-117 早期に診断しえた特発性食道破裂の 1 例 伊地隆晴, 長㝘悦子, 岡部安博, 友利寛文, 伊佐 勉, 我喜屋亮, 比嘉淳子, 城間 寬

(豊見城中央病院外科)

比㪟的早期に診断・手術が行われた特発性食道破裂の1例を経稌したので報告する。症例 : 47

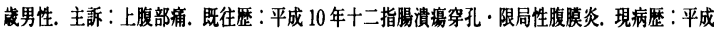
15 年 8 月 14 日：午前 1 時 30 分, 哽吐した後より上腹部有出现. 同日午前 2 時 30 分：当院救急

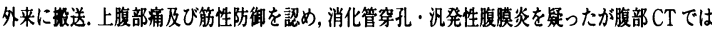

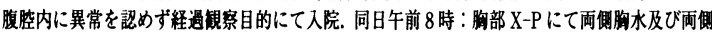

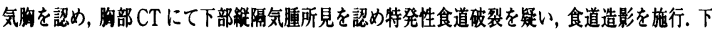

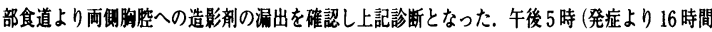
後）䋈急手術施行．下部食道に約 $3 \mathrm{~cm}$ の裂傷を認め，食道破裂部位を simple closure にて閉鎖

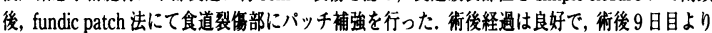

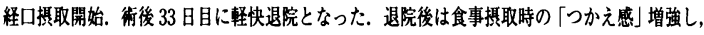
退院後 14 日目（衍後 47 日目）に食道内梘鏡施行. 下部食道の破裂部位に一致して全周性の㹟宏

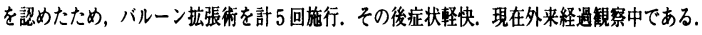

PPS-3-118 有茎大網被覆を用いて 1 期的に䋖合閉鎖を施行した特発 性食道破裂の 1 例

夏 錦言, 松浦芳文, 井上 聡, 飯田修平

(練馬総合病院)

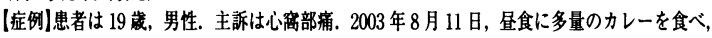

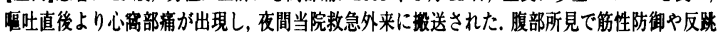
有を認めず，採血所見は白血球数 $9300 / \mathrm{mm}^{3}$, CRP $8.6 \mathrm{mg} / \mathrm{dl}$. 胸部 XP·CTにて䋖隔気腫を認

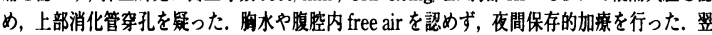
日，食道造影を行ったところ，下部食道右壁侧より䋖隔へ造影剂の漏出を認め，発症後 30

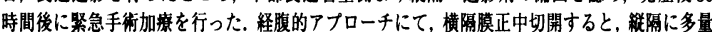

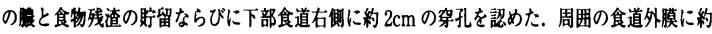

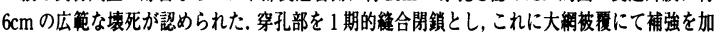

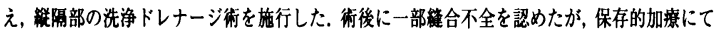
回復し，退院した、今回，手術加療の決定までに要した時間的な問㬏を検討するとともに，術

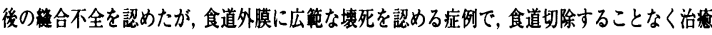
したことを考虑すると，大絧被覆は維合部の補强として大変有用な方法と考えられた。

PPS-3-119 胃癌を併発した食道破裂の一例

中野 徽, 菅原 浩, 橋本正治, 中村 聡, 伊藤悪紀, 三浦美樹, 甘利正和, 佐藤雅栄, 平野 裕, 海法恒男

(由利組合総合病院外科)

症例は56歲，男性. 平成 15 年 10 月 19 日，突然の煊気を生し，近医を受診し，点滴を受け 慢宅した。翌朝，再度，近医で点滴を受けた直後に唒吐と吐血を生じ，さらに激しい胸背部

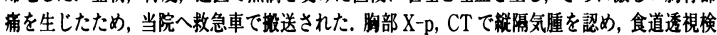

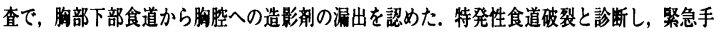

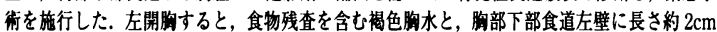
の破裂部を認めた。洗浄ドレナージ術と Tチューフによる食道外慺造設術を行った。術後経 通は柾めて良好であったが，術後の透梘で幽門部から十二指腸への通通不良を認め，胃内梘

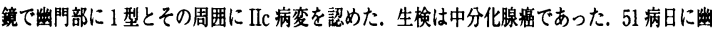
門㑭胃切除術を施行した，食道破裂から65病日，胃㿋手術加ら15 日目に退院した。特発性 食道破裂は予後不良な救急疾患であるが，本例は食道外慺造設術により良好な経過が得られ た. 特発性食道破裂と胃峦の合併の報告は稀で，本例が本邦の7例目である. 本例では，胃 癌による幽門部の通週障害が特発性食道破裂の発症の誘因と考えられ，大変與味深い。

PPS-3-120 経食道裂孔アプローチによる手術を施行した胃 Dieulafoy 埧場を伴った特発性食道破裂

門脇嘉彦，田村竜二，岡本貴大，金子晃久，坂田龍彦 (神戸赤十字病院外科)

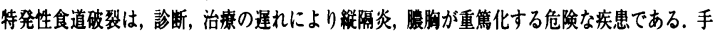

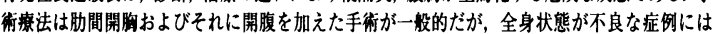
かなりの侵襲であり，手術そのものか致命的となる可能性がある. 今回我々が経駼した特発性 食道破裂の症何を報告する。症例は 55 歳男性。吐血にて近医受診。病院での吐血後に胸扁方

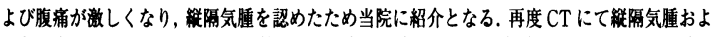
び左胸水を認め，さらに上部消化管造影にて左胸脂内穿破を伴う食道穿孔と䛦断し孟急手術 施行した。開腹にて食道裂孔にアブロー千すると下部食道の左僋後壁に約 $6 \mathrm{~cm}$ の裂創を認め,

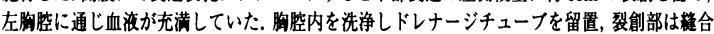
閉鎖し，胃噴門部にて被覆をした。胃の前壁をオープンすると胃体部後壁にDieulafoy 潰鹪を 認め,それが出血源であったので, 部分切除を行った。患者は経週良好であった。特発性食道

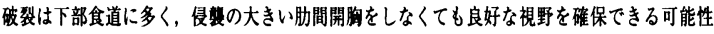

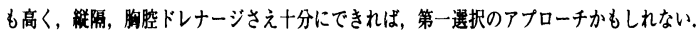




\section{PPS-3-121 食道原発悪性黒色腫の 1 例}

中島 亭", 小関萬里"), 砂田祥司", 畑中信良 ${ }^{11}$, 富永晴海",

黒住和史", 寺本成一"1), 上池 涉", 藤本淳也 ${ }^{2}$, 谷山清己21

(国立病院吳医療センター外科"), 国立病院呉医療センター病理")

(症例) は 61 歳男性で, 平成 15 年 7 月 30 日, 検診にて胸部食道に長往約 $4.5 \mathrm{~cm}$ の隆 起性病変を指摘された. 入院時, 自覚症状は認めず，内梘鏡検査にて，上切菌列より $34 \sim 37 \mathrm{~cm}$ に白色調の隆起性病変を認め, 生検にて悪性黑色盾, amelanotic type と診断 された. (治療) 術前化学療法として, DTIC+ACNU+VCR と INF $\beta$ 局注を併用し， 1 クール施行した，その後，主病変を再評価し，食道严全摘，頚部胃管吻合にて再建術を 施行した。 (病理学的検査) 切除標本では, $49 \mathrm{~mm} \times 33 \mathrm{~mm}$ 大の白色調隆起性病変を認 め, 診断は朢性黑色腫 amelanotic type, 深達度 sm, n0, Stage lbであった. (考察) 食 道原発悪性黑色腫は比較的まれな疾患で, 全食道悪性腫湟中の $0.1 \sim 0.5 \%$ といわれて いる. またその予後は不良で， 5 年生存率はその他の食道潘と比較しても低率である. また, 本症例の病理組機は, 食道悪性黑色腫の中でも $18 \%$ 程度を占めるにすきない amelanotic type であり，さらに稀な疾患であった（まとめ) 今回我々は，此較的稀な 食道覀性黒色腫の 1 例を経験したので，文献的考察を加えて報告する.

PPS-3-122 食道悪性黑色腫の 1 例

松本 浩, 加瀨 肇, 栗原聡元, 戸倉夏木, 菊池 誠, 斉藤直康,

㷊澤尚宏, 石井紀之, 小林一雄, 柴 忠明

(東邦大学第 1 外科)

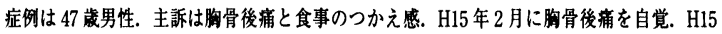
年 7 月に再び同様の症状を認め, 人間ドック受診し，下部食道に3 個の隆起性病変を指摘さ れ，当院紹介となった。体表面には黒色腫を簃わせる病変を認めなかった。 上部消化管内视

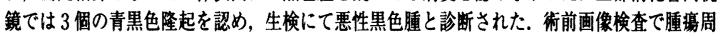
辺リンパ節および頝部リンパ節腫脤を認めなかった，同年 9 月 2 日，食道要全墒術，リンパ

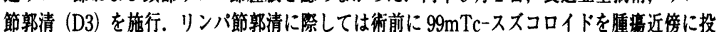
与し, sentinel node navigation surgery を施行したが, 反応りンバ節を認めなかった。病理組

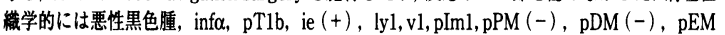
(一), noであった. 免疫染色ではフォンタナマッソン $(+)$, HMB-45 (+), S-100,CEA (+)であり，黑色腫として矛盾しなかった。術後DAVーインターフェロン㙩法を施行後退院. 術後 4 个月現在, 再発を認めていない, 食道悪性黑色腫は会境録を含め, 本邦約 220 例であ

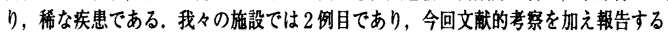

PPS-3-123 食道原発 amelanotic malignant melanoma $の 一$ 例 友利寛文, 伊佐 勉, 長葶悦子, 岡部安博, 伊地隆晴, 我喜屋完, 比嘉淳子, 城間 宽

(豊見城中央病院外科)

症例は, 81 嵅. 女性. 当院内科で慢性関節りウマチを治療中, 平成 15 年 3 月より呰下難が生じ同年 6 月内視鏡検查をおこなったところ中部 食道に隆起性病変を指摘された。病理組織検査で悪性黒色腫と診断され 当院外科紹介となった，手術は高齢で䫫部伸展できないため同年 7 月 1 日鏡視下手術を採用し胸腔内吻合を行った。摘出標本では $40 \times 20 \mathrm{~mm}$ の色素沈着症を伴わない有茎性の病変を認め肛門側にも $10 \times 10 \mathrm{~mm}$ の 黒色色素沈着を伴う隆起性病変を認めた。術後補助化学療法は皮用の悪 性黒色腫に準じて DAV (Dacarbazine, Nimustine, Vincristine) 療法を 行い 8 月 8 日退院となった。食道原発悪性黒色腫は全食道悪性疾患の $0.5 \%$ 以下と非常にまれな疾患である. また予後不良で治療法に関して も確立されたものが無いのが現状である. 今回演者らは食道原発悪性黒 色腫の一例を経験したので報告する.

PPS-3-124 集学的治療により長期生存した進行食道未分化癌の 1 例 金子雅宏, 大杉治司，竹村雅至，本 栄柱，藤原有史，西澤 聡，

岩䗁 洋

(大阪市立大学消化器外科)

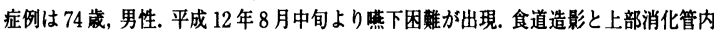

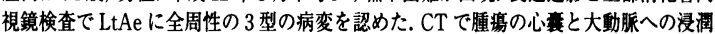
が筷われたため, $5 \mathrm{FU}(200 \mathrm{mg} / \mathrm{day})$ の経口投与を 57 日間行った。この間に検查を行 い，血管内超音波所見で明らかな大動脈浸洞を認めなかったため, 平成 12 年 12 月 4 日手術を行った。術中, 心婁, 右下肺, 左胸膜への直接浸潤を認め, 3 領域りンバ節郭 清を伴う食道切除と, 心裹, 右下肺, 左胸膜の合併部分切除を行った。病理組機学的に は非小緗胞型未分化澺で, pT3, pN4, pStage IVa であった。術 3 ケ月後に退院し, 近医 で $5 \mathrm{FU}(500 \mathrm{mg} /$ day $\times 4$ weeks) とシスプラチン ( $10 \mathrm{mg} /$ day, 5 days/week $\times 4$ weeks) による化学療法と 44Gy の放射線寮法を行った。現在術後 3 年経過したが無再発生存 中である. 食道未分化就は治旗成績が梗めて不良であり，その方針については未だ確立 されていない、今回,リンパ節郭清を伴う食道切除と補助㙩法を併用した集学的治㫫に

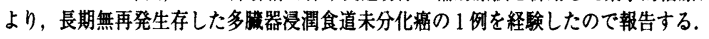

PPS-3-125癌腫・肉腫两成分のリンパ節転移を伴った食道癌肉腫の 一例

岩谷 岳"，木村咗輔"，池田健一郎"，前沢千早 ${ }^{32}$, 上杉憲幸"

野田芳籍", 石田 萧", 肴藤和好"

(岩手医科大学第 1 外科", 岩手医科大学臨床病理", 岩手医科大学第二病 理 $\left.{ }^{3}\right)$

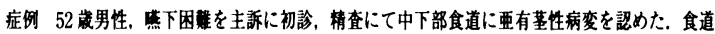

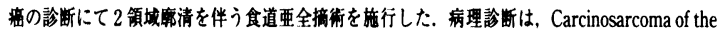
esophagus, lp 型, MtLtAe, 170x98mm, pT3 (pAd)，pN4 (3b)，M0, lyl,vl, stage IVa. 䈏 腄成分は well differentiated squamous cell carcinoma であった，肉霍成分は束状を成す䅅篗形

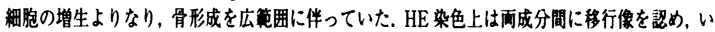

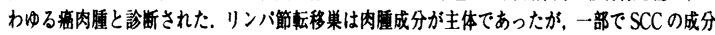

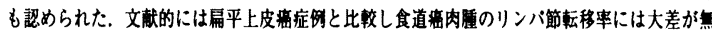

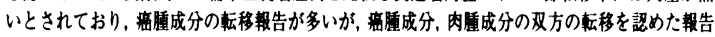

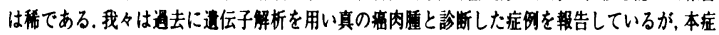

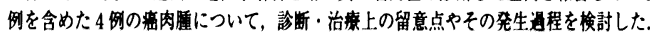

\section{PPS-3-126 食道 GIST $の 1$ 切除例}

小林和明，桑原明史，渡辺直純，林達彦，村山裕一，清水春夫 (村上総合病院外科)

今回我々はまれな食道 GISTの1例を経験したので報告する。(症例) 59 歳男性 H15.7.11 喗吐, 胸部不快感を主訴に当院内科を受診した。部消化管内梘鏡検查 にて胸部中部食道に白苔に得われた表面平滑な隆起性病変を認めた。胸部 CT で胸部中部食道内腈に突出する腫就性病変を認めた。胸腹部 CTでは肺転移, 肝 転移は認めなかった. 術前訩断は so called carcinosarcoma が疑われ，手術目的 に当科転科となった. H15.8.13 手術は右開胸食道切除 R0 D1 CurB, 頞部食道胃

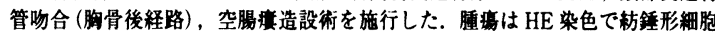
が束状に配列しており，核分裂像を認めた．免疫組苝化学的に $\mathrm{c}$-kit 陽性, CD 34 陰性, $\alpha$-SMA 陰性, S-100 隆性であり切除標本の診断は食道 GIST であった。 (考察) 部位別 GIST の類度は, 胃 60 70\%, 小晹 $20 \sim 25 \%$, 大腸 $5 \%$, 食道 $5 \%$ であり食道は平滑筋腫が多く, GIST の類度は少ない。本邦食道 GIST の報告例 はこれまでに 15 例あり，本例で 16 例目である.（まとめ)手術にて䢖残なく切除

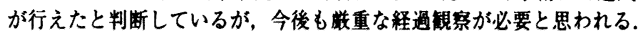

PPS-3-127 食道原発大細胞性神経内分泌瘦の一例

榎本正統"，高木 融", 逢坂由昭", 星野澄人”, 立花慎吾”,

土田明彦", 青木達哉", 大城 久2', 芹沢博美"

(東京医科大学第 3 外科", 東京医科大学病院病理部 ${ }^{21}$ )

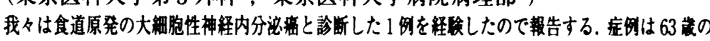

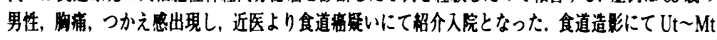

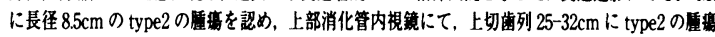

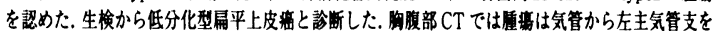

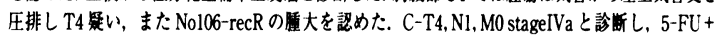

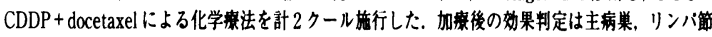

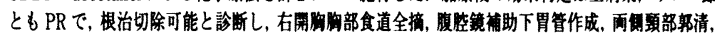

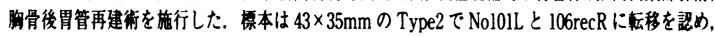

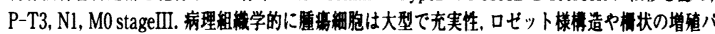

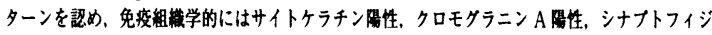

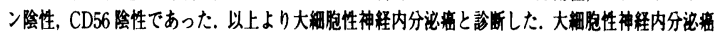
は肺にわいて報告を散見するものの，食道原発の報告はきわめてまれである。

PPS-3-128 食道 Verrucous carcinoma の 1 例 野中健太郎, 井手春樹, 岩瀨和裕, 山東勤弥, 位藤俊一, 三方彰喜, 水島恒和, 甲斐沼尚, 山中宏章 （市立泉佐野病院外科）

食道 Verrucous carcinoma は国内外で 10 数例しか報告がなく，非常に稀な在患である。

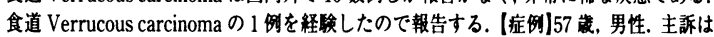
上腹部浦. 00 年 9 月，食道アカラシアに対し腹陡鏡下 Heller-Dor 法を施行した. 術中

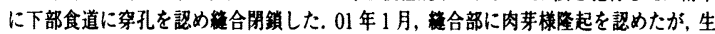
検で異型細胞は認めなかった。 02 年 10 月，上腹部㳦の再然を認め，下部食道に全周性 隆起性病変を認めたが, 患性細胞は認めなかった。 03 年 1 月, 下部食道の病変はカリフ

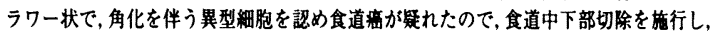
Verrucous carcinoma と診断された. 肝檕移のため術後 2 ケ月目に死亡した. [考察]本 症は，食道の惲性炎症性疾患を背景とすることが多く，カリフラワー状・疫状で, 異型

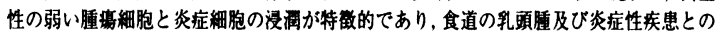

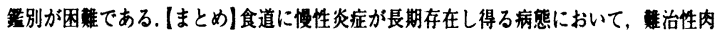
芽を認めた場合は本症の可能性を念頭に鱿く必要があると考えられた。 
PPS-3-129 SM 食道橎の死因解析

林 香織, 本山 语, 丸山起誉幸, 奥山 学, 小川純一 (秋田大学第 2 外科)

1989 年から 2001 年までの食道舟手術症例 400 例中，SM 食道盘は 80 例 (20\%)でこれ らを対象とし，予媵，死因，再発形式などについて検討した. SM 整 80 症例のうち要 分類別では SM1-27 例 $(34 \%) ， \mathrm{SM} 2-18$ 例 (23\%)，SM3-35 例 $(54 \%)$ で，5年生存 事はSM 艒全体で 60\%, SM1-73\%, SM2-63\%, SM3-57\%であった. 5 年生存を得な

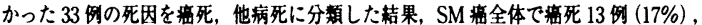

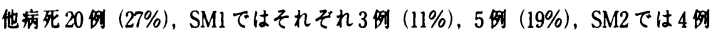
$(22 \%) ， 4$ 例 (22\%)，SM3では6例 $(30 \%) ， 11$ 例 $(38 \%)$ であり，深達度が SM1 から SM3 へと深くなるに従って上昇し，一方他病死は癌死より多く，死因としては原

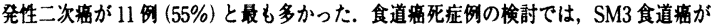
多く $(46 \%)$, 腫倍型ではIpか IIa の隆起性病変が多く、リンバ節転移は $70 \%$ 以上の 症例で認めた. SM 食道盘では術後食道启死症例以上に他病死症例が多く，他病死症例 の克服が必要と考えられた. SM1 盘は手術によりはとんどの症例で治䈍が得られるも

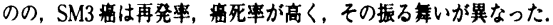

PPS-3-130 びまん浸潤型食道癌の郜床病理学的特幑と治療成縝 田戛 匡, 神田達夫, 池田義之, 石川 卓, 矢島和人, 小杉伸一, 中川 语, 大樆 学, 畠山勝義

(新潟大学大学院消化器. 一般外科)

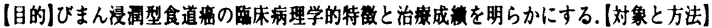

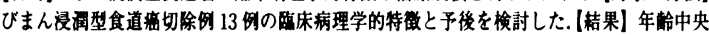

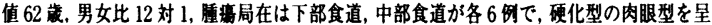

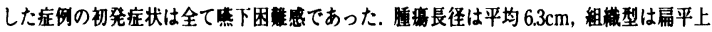

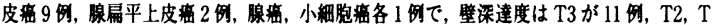

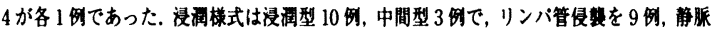

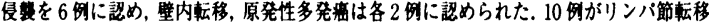

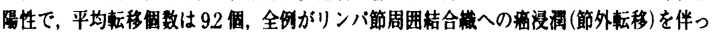
ていた，予後の明らかな 12 侏中 7 侏が再発，全てリンバ節再発を含んだ再発形式で，累

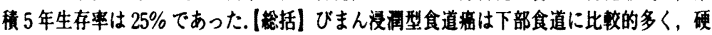

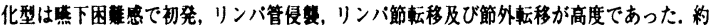
6 割がリンバ節再発を来し, 5 年生存审は $25 \%$ と T4 症何の成儥に近かった。

PPS-3-131 食道癌多発リンパ節転移（転移数 20 個以上）症例の検討

植村 守, 土畦裕一郎, 宮代 勲, 高地 耕, 山田晃正, 村田幸平, 大東弘明, 佐々木洋, 石川 治, 今岡真義

(大阪府立成人病センター外科)

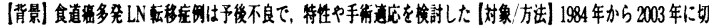

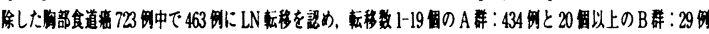

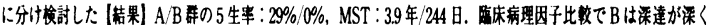

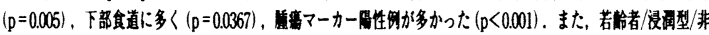

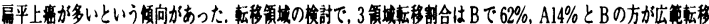

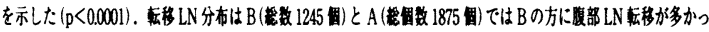

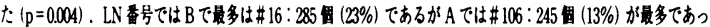

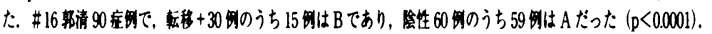

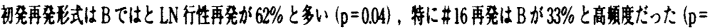

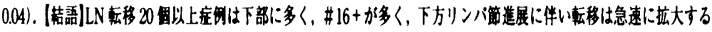

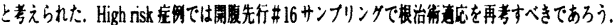

PPS-3-132 食道腺㙖の切除症例の検討とその治療方針 細井則人, 山田和彦, 瀬戸泰之, 山口俊晴, 武藤做一郎 (瘦研究会病院消化器外科)

【はじめに|Barrett 食道腺需は少なく，その術式選択に一定した見解は得られていない． 当院での食道腺峦症例から, 這切な術式の検討を行なった. (対象/1987 年から 2001 年ま

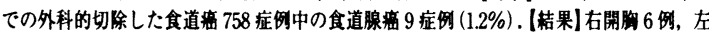

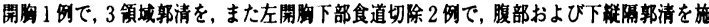
行. 9 例中 8 例にBarrett 食道をみとめ，長さは 20〜 $135 \mathrm{~mm}$ (平均 $71 \mathrm{~mm}$ ). 主病変部位

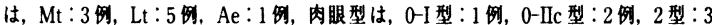

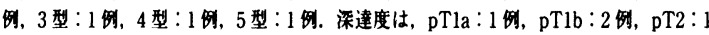

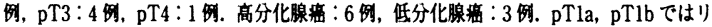
ンパ節転移はみられなかったが, pT2 以上ではリンバ節転移をみとめた.このうち, Ae 領城の pT2では腹部のみに轱移がみとめられたが，pT3以上の Lt 症例では腹部と上中

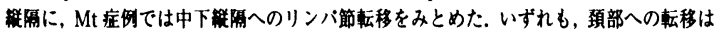

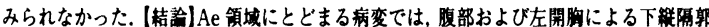
清を，Lt，Mt 領域では，腹部および上梿隔までの部清が必要であると考える.
PPS-3-133 食道粘膜下腫韵に対する適切なアプローチの選択

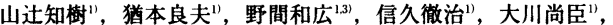

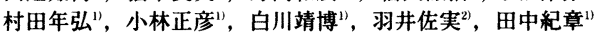
(岡山大学大学院消化器 - 腫淘外科学 ${ }^{1)}$, 岡山市立市民病院外科 ${ }^{2}$, 重井医 学研究所病院外科 ${ }^{3 \prime}$ )

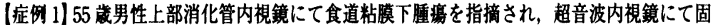

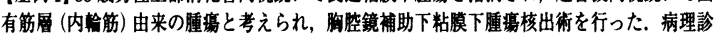
断は平滑筋腫. (症例2) 69 歳男性 5 年前より上部消化管内視鏡にて胸部中部食道の粘膜下

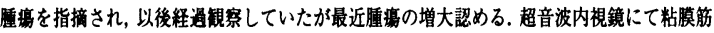
板由来と考えられた，全身麻醉下内視鏡的粘膜下腫場切除術を行う，病理診断は平滑筋腫.

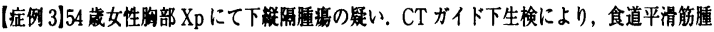

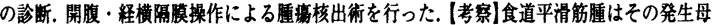

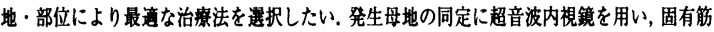
層由来のものに胸哓镜下筋腫核出術を行い，粘膜筋板由来の病変に対しては内梘鏡的切除 を行った．下部食道の巨大平滑筋腫に対しては，開腹・経横隔膜操作による腫沮核出術を 行った，食道粘膜下腫㾇に対する䔔切なアプローチをその発生部位から検討したい．

PPS-3-134 食道癌患者における末梢血単球，リンパ球比の臨床的意 義

湿㴊俊二, 石川忠則, 前田博教, 岡崎泰長, 松本康久, 笹栗志朗 (高知大学第 2 外科)

【目的と方法】術前無治療の食道病症例における術前の末梢血単球/リン パ球比と原発巣の壁深達度との関係, さらに再発症例における再発前後 での末梢血単球/リンパ球比の変動について検討を行った. 対象は, 根治 術が施行された 118 例（pT1 52 例, pT2 21 例, pT3 45 例）とバイパス 術 (T3 or T4) が施行された 26 例である．再発症例は， 24 例について検 討を行った.【結果】術前の末梢血単球/リンバ球比は, pT1 : $0.219 \pm$ 0.090 , pT2 $: 0.245 \pm 0.108$, pT3 $: 0.288 \pm 0.147$ (p<0.01 vs. pT1), T3 or T4 : $0.368 \pm 0.268$ (p<0.01 vs. pT1, p<0.05 vs. pT2) であった. また再発 症例の再発前は, $0.328 \pm 0.118$, 再発時は, $0.517 \pm 0.243$ ( $\mathrm{p}<0.01$ vs. 再発 前)であった.【まと】癌の進行に伴い, 末梢血単球/リンパ球比は有意 に上昇していたことから，食道癌患者での癌の進行度，再発の指標とな る可能性が示唆された。

PPS-3-135 胸部食道癌術後再発形式に関する検討

鈴木崇久，㭘原 淳，上野秀晃，田道和照，吉田和弘，山口佳之， 㠿 哲哉

（広島大学原医研腫場外科）

方法: '90 年 7 月より'01 年 7 月まで当科にて食道切除再建術を施行し 2 年 以上経過した胸部食道軜 182 例を対象として再発部位・予後を検討した。 結果：各病期の生存率（2 年）は, stage0 95.8\%stage $1100 \%$ stage $265.1 \%$ stage $346.2 \%$ stage4 $27.1 \%$ となり, stagel と 2 stage2 と 3 に統計学的有意 差を認めた. 再発死亡症例 84 例の検討で, 再発初発部位はリンパ節再発 29 例 $(34.5 \%)$ ，遠隔転移症例 22 例 $(26.2 \%)$ ，胸・腹膜再発症例 14 例 $(16.7 \%)$, 局所再発 19 例 $(22.6 \%)$ であった. 各再発初発部位で術後から再発までの期 間・再発後の生存期間の比較検討を行った．各群間に統計学的有意差はな かった. 各病期の再発までの期間 (75\% 值) は stage1808days stage 2500 days stage3 336days stage4 296days であった．結語：各病期の再発は術後 2 年以内であり, 再発部位・再発後生存期間に偏りを認めなかった.この間 の敞重な管理が必要で，再発した場合の有効な治療法の開発が望まれる.

PPS-3-136 反回神経周囲リンパ節 (106rec) 転移に対する術前超音波 内視鏡 (EUS) 診断についての検討

白川博文 ${ }^{1}$ ，井垣弘康 ${ }^{1}$ ，日月裕司 ${ }^{11}$ ，加藤抱一 ${ }^{12}$ ，後藤田卓志 ${ }^{2}$,

小林 望2), 神津隆弘 ${ }^{2)}$

(国立がんセンター中央病院食道外科 ${ }^{1}$ ，国立がんセンター中央病院内視 鏡部 ${ }^{21}$ )

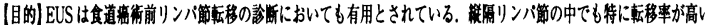

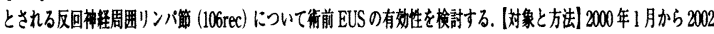

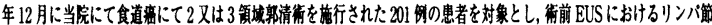

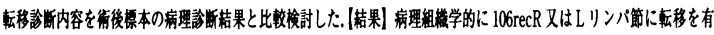

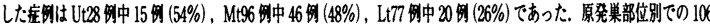

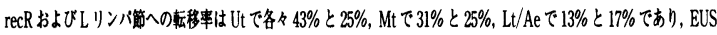

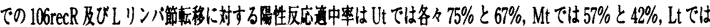

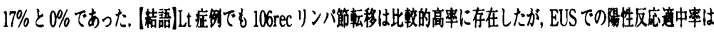

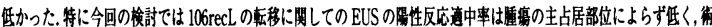
前EUS 上同部位にリンバ節轻移を証めないからといって部清を省略することはできない 
PPS-3-137 Diffuse leiomyomatosis of the esophagus の再発例に対す る手術経験

系井和美, 水野恵文, 西川秀文, 福山 学, 澤田 尚, 白潟義晴,

篗原 尚, 倉橋康典, 佐藤元彦, 佐々木直也

(兵庫県立尼崎病院外科)

(目的】 Diffuse leiomyomatosis of the esophagusの再発症例に対し，上行落腸による再建を用いた

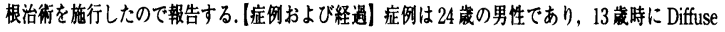
leiomyomatosis of the esophagusにて下部食道切除, 胃管による再建術を施行されていた.今回食锥

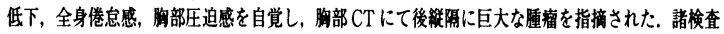

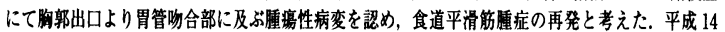

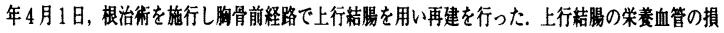
侮を防くため，前回用いた胃管は摘除しなかった［考察】 Diffuse leiomyomatosis of the esophagus

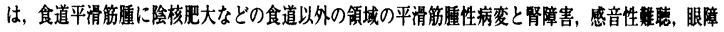
害を合併したX染色体隻生道伝の疾患でるる Alport-leiomyomatosis との異同が問題になる，本症

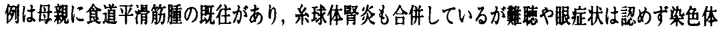
検查にても X 染色体に異常は認めず Alport-leiomyomatosis は否定的と考えている。

\section{PPS-3-138 腐蝕性食道狭窄の外科治療}

中谷佳弘, 中 禎二, 岩橋 誠, 瀧藤克也, 山上裕機

(和歌山県立医科大学第 2 外科)

[はじめに］塩酸誤飲による腐蝕性食道狭窄の症例を 2 例経験した，腐 蝕性食道狭窄の治療に関しての問題点につき考察を加え報告する. [症 例] 症例 $1: 54$ 藏, 女性. 整病治療中に, 自殺目的に塩酸を服用した. 経過観察中に,ブジーによる拡張術を繰り返して行ったが狭窄は改善せ ず, 14 カ月目に手術を行ったが, 気管との剥離困難と判断しバイパス術 を行った. 症例 $2: 38$ 藏, 女性. 自殺目的に塩酸を服用した. 1 力月後に, 幽門部狭窄で経口摄取不能となり, 胃空腸吻合術を施行した. その後次 第に食道狭窄症状が進行し，フジーなど保存的治療を試みたが効果な く, 食道胃切除を行い右側結腸再建を行った. 2 例とも術後経過は良好で ある. [まとめ] 腐蝕性食道狭窑は, 急性期のみならず, 手術時期・腐蝕 食道の癌化に留意する必要がある，症例 1 では腐食食道が残存し，举重 な観察が必要と考えられた。文献的に腐蝕性食道狭窄の治療における問 題点に関して論じる.

PPS-3-139 食道穿孔に対する内視鏡的経鼻経食道紩隔ドレナージの 有用性について

水野英彰, 阿部展次, 伊藤尚真, 鈴木 裕, 吉田孝司, 柳田 修, 杉山政則，跡見 裕

（杏林大学第 1 外科）

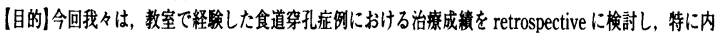

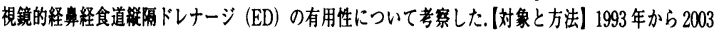

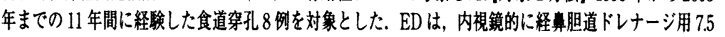

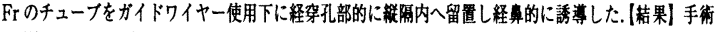

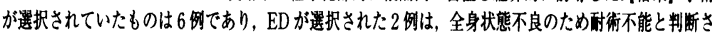

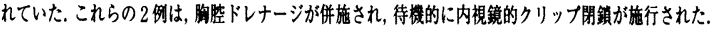

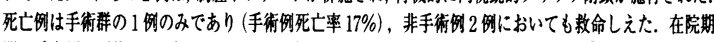
間住手術例で平均 57 日 (16-137日)，非手術列では平均 45 日（36-54日）であった，考察】手術まで長

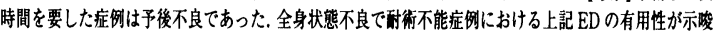
された。食道穿孔で慥道切な手術をまず考慮する必要があると思かれるが，全身状態不良なとで聚急手

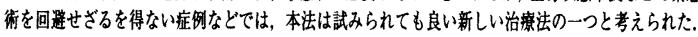

PPS-3-140 顠胸部食道に嵌頓した大型有鈎義柬摘出上の問題点 森脇義弘, 山本俊郎, 小菅宇之, 杉山 貢

(横浜市立大学救命救急センター)

【背景と目的】義蔽誤敛の対応は通常容易であるが，繁爪状の鈎を有する大型のフリッ

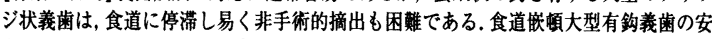
全確実な摘出法を考案した. [対象と方法] 彯胸部食道の有鈎義菌嵌頓 5 例で，1）摘出 時の義歯の動き，2)摘出後の内視鏡所見，3）食道切除例では切除標本で比頓部の状況， を㛟討した. [成䋶]全例, 非手術的に摘出できなかった. 全身麻醉下で, 食道直達鏡下 摘出 1 例, 顠部斜切開䫫部食道露出後の用手的誘導下での経口的直接把持摘出 1 例, 垔 部食道切開摘出 1 例で, 3 例とも水平方向へ回転させた後に移動可能となり摘出でき た. 摘出後の刺入部は小損賃のみであった. 胃へ落下後胃切開での摘出 1 例は, 胃への

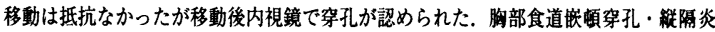
で食道切除が 1 例で，摘出食道にはクラスフの水平方向への刺入穿孔と口側に向かっ

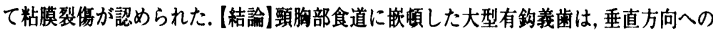
毫引は粘膜裂傷穿孔をきたす危険が高く，まず，水平方向に回転させてから移動させる のが安全と思われた．摘出後は内視鏡での観察が必要と思われた。
PPS-3-141 食道入口部浸洞を伴う進行甲状腺癌に対する治撩選択 杉野圭三”，矢野将解"，西原雅浩"，川口康夫"，川西秀澍"，

新原 亮"，春田直樹"，渡造浩志"，岡本英樹" ，浅原利正 ${ }^{2 \prime}$

(あかね会土谷総合病院外科"，広島大学第 2 外科" ${ }^{2}$ )

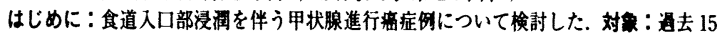

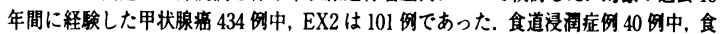

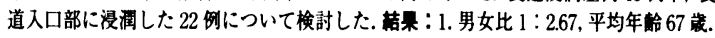

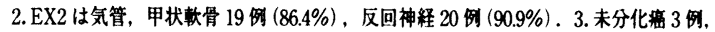

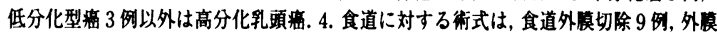

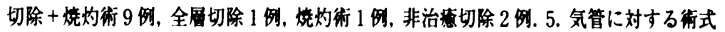

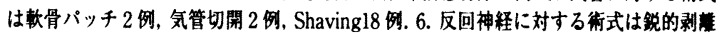
温存 10 例, 反回神経再建術 8 例，切断 2 例. 7. 5 例に局所再発を認め, 再手術施行.

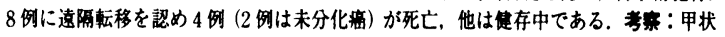
腺密の場合，予後左右因子が遠隔転移であることを考虑すると QOLに配虑した機能温 存術が求められる。娭頭全摘以外に Surgical margin の取れない食道入口部では外谟切

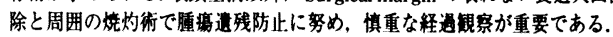

PPS-3-142 食道結核の検討一原発性食道結核を中心として加藤 弘, 和田則仁, 徳山 丞, 北條隆, 島田 效, 大石 崇, 磯部 陽, 寉地 淳, 池内駿之

(国立病院東京医療七ンター外科)

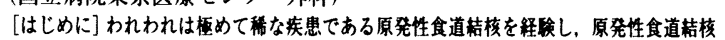

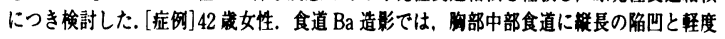

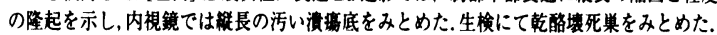

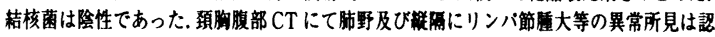

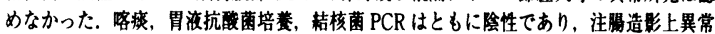

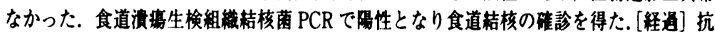

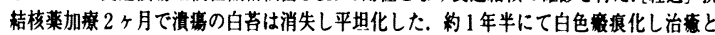

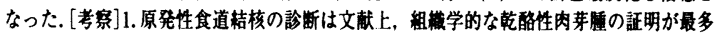

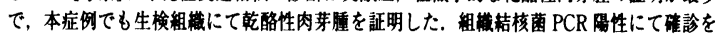

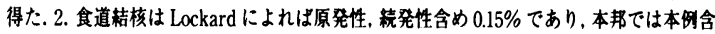
め 43 例で, うち 3 例で原発性と確診された。原登性詥断には，高棈度 CT等が必要と思わ

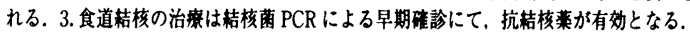

PPS-3-143 食道原発小細胞癌における術前内視鏡検査での注意点と 免疫組織学的検査の有効性

山本純也", 大島孝一"2, 岩崎 宏"', 池田靖洋"

(福岡大学第 1 外科", 福岡大学病理学 ${ }^{2}$ )

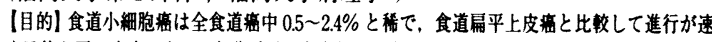

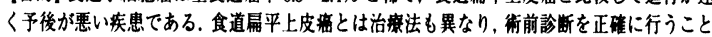

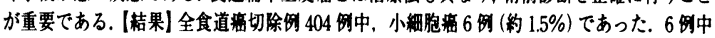

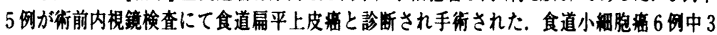

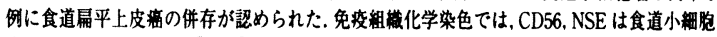

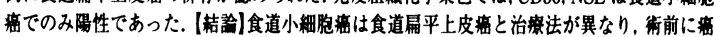

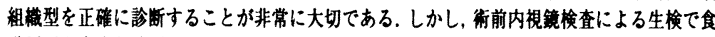
道扁平上皮㿋と診断されることがあり，その原因として，生榙した組模が少なく食道扁平上

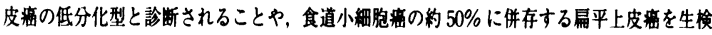

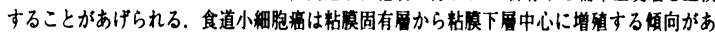

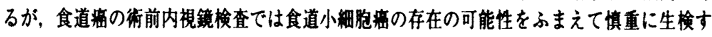
る必要があり，その籍別には，CD56,NSEの免疫組權化学染色が有用であった。

PPS-3-144 食道癌に対するステント㞠法の逼応と意義について 玉硻英俊, 山田行重, 高演靖, 成清道博, 上野正䦥, 大東雄一郎, 三木克彦, 水野崇志, 中島祥介

(奈良県立医科大学第 1 外科)

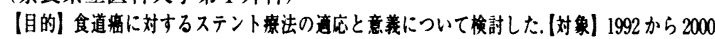

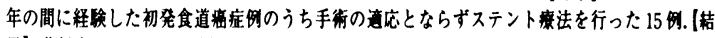

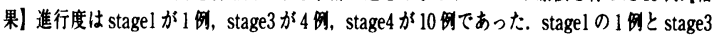

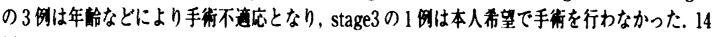
例に radiation therapy (以下 RT) が行われた。この14网のステント搏入の理由は, RTの奻果

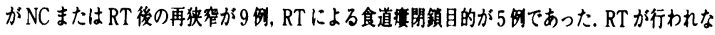

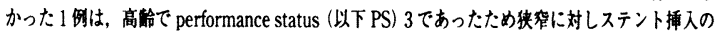

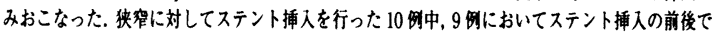

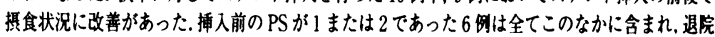

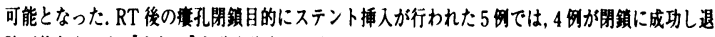

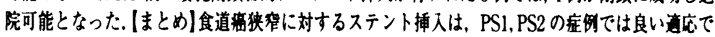

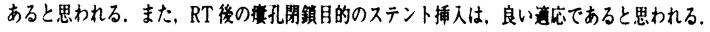


PPS-3-145 悪性食道狭㹱に対するステント療法の適応と意義 今津嘉宏, 河原真理, 伊東大樹, 小林美里, 竹内俊介, 村山剛也, 斎藤直康, 大山廉平

(済生会中央病院外科)

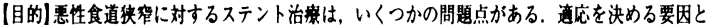

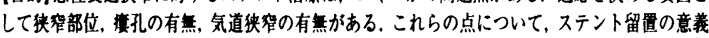

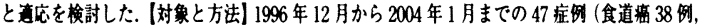

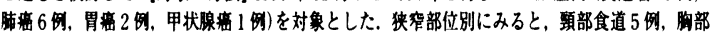

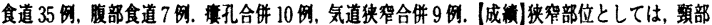

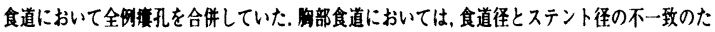

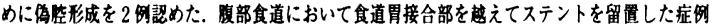

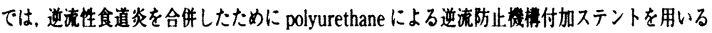

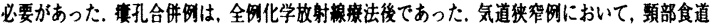

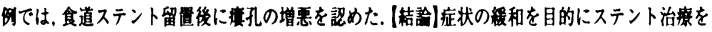

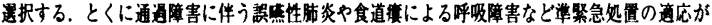

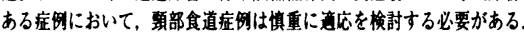

PPS-3-146 切除不能食道被症例に対するステント治療の意義 大平雅一"，山下好人"，久保尚志"，阿古英次"，井上 透"， 西原承浩"，山田蜻哉"，西口幸雄"，加藤保之"，平川弘聖" (大阪市立大学腫鹪外科"，大阪市立捴合医療センター外科 ${ }^{2}$ )

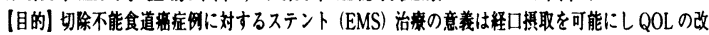

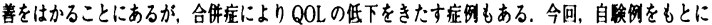

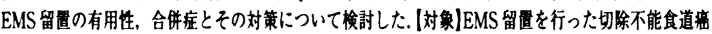

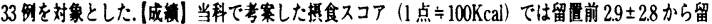

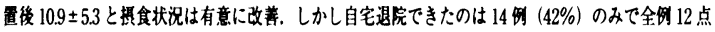

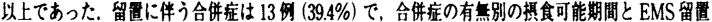

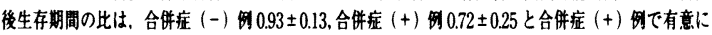

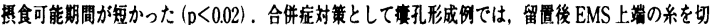

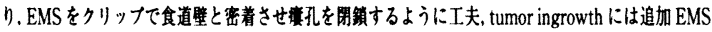

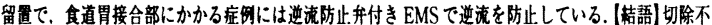

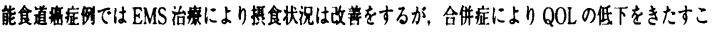
とがある，合垪痤を防ぐ夫により本治賞法の有用性がさらに向上すると考えられる。

PPS-3-147 食道ステントの適応について 佐野 涉, 知久 媇, 加藤一喜, 田村英彦, 棉場隆裕, 江連理佳, 田代要彦

(厚生連上都賀捴合病院外科)

【目的】手術不能食道蜜に対する食道ステント例を検討した（対象と方法】食道又 テントを㨉入した 23 例が対象で, 手術不能と判断した理由としては, 癌の周囲腷器

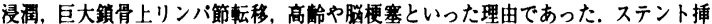
入前の Performance status（以下 PS）に着目し㨂入後の経口摄取量等を検討. (結 果】ステント挿入前のPSは，PSOが 4 例，PS1 が 10 例，PS2 が 3 例，PS3が 3

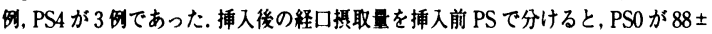
$12 \%$ (平均士標泮誤差)，PS1 が $91 \pm 6 \% ， \mathrm{PS} 2$ が $53 \pm 29 \%, \mathrm{PS} 3$ が $17 \pm 3 \%$, PS 4 が $37 \pm 32 \%$ であった (通常時摄取量との比較)．改善を認めなかった 4 症例は挿 入前 PS2が 1 例, PS3 が 1 例, PS4 が 2 例であった。 さらにステント挿入後の在宅 事(在宅期間/生存期間 $\times 100 \%$ ) はPSO から 2 までは $45 \pm 7 \%$ であるのに対してPS が 3 以上では $18 \pm 13 \%$ と有意に短かった. [考察】㨉入前PSが 3 以上となっている 症甽では充分な奻果が得られない場合が多く慎重な道応決定が必要である。

PPS-3-148 食道㾇に対するステント治療の問題点と適応の再考 若林和彦"，宋 圭男"，小林秀昭"，增田英樹"，藤井雅志"，

高山忠利"

(日本大学第 3 外科")

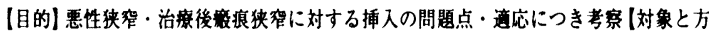

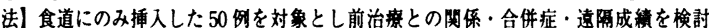

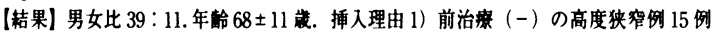

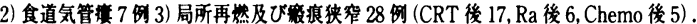

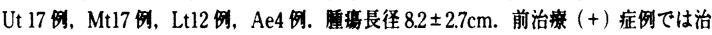

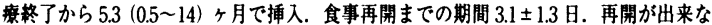

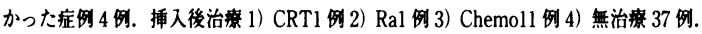

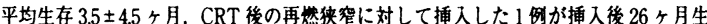
存中 [供筧]. 短期合併症 $(-)$. CRT 後の Ut 局所再然に対して挿入した 5 例 (5/6)に

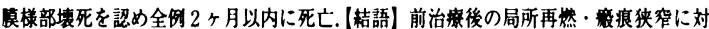
しても安全に挿入することは可能であり早期経口栄飬の再開, PS の向上を図ることが 出来万．根治的 CRT 後の Ut 症挒に对しての㨉入は膜粎部壊死の危険性が高い。
PPS-3-149 特発性食道破裂に対し食道ステントが有用であった 2 例 羽田真朗, 芦沢一喜, 宮坂芳明, 石山 準, 稲垣栄次, 渡辺光章, 中井克也，中込 博，三井照夫，千葉成宏

(山梨県立中央病院外科)

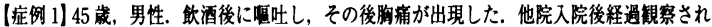

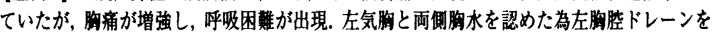
挿入された。特発性食道破裂と診断され紹介転院となった。全身状態力悪化し胸胫ドレーン 挿入，人工呼吸管理を行った。院 3 日後に食道ステントを㨉入した。 その後, 次第に胸水 の娍少がみられ全身状態の改善をみた，入院後 65 日に開腹にてステント抜去を行い 76 日

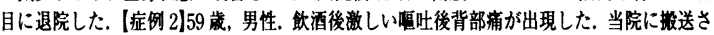
れ緊急入院となった。精査にて特発性食道破裂と診断した. 皮下気腫, 呼吸苦が增強した為,

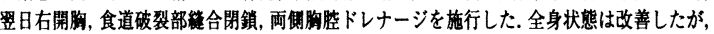
術後 10 日目に綎合不全が判明した。軽快㮌向みられず術後 17 日に食道ステントを㨉入。轾 快した為，術後 45 日にステントを内視鏡下に抜去した，その後食道狭害となり，内視鏡下 搪張術を要したが術後72 日に退院した（結語) 特発性食道破裂におけるカバー付き食道又 テントは，破裂部の保存的治㫫や術後の綎合不全に対して有用であった。

PPS-3-150 食道 spastic disorders に起因する㖓下障害に対する治療 経験

藤原有史，大杉治司，竹村雅至，李 栄柱，金子雅宏，西澤 聡，

岩崎 洋

(大阪市立大学消化器外科)

䜿下障害を伴った食道 spastic disorders に対し加療を行った 5 例を報告する。症例 $1 ; 32$ 歳, 男性. 同期性収縮, LES 不完全驰縟があり diffuse esophageal spasm と診 断. LES 不完全驰緅に对して, バルーン拡張術を施行. 22 ヶ月後も再然なし. 症例 $2 ; 56$ 藏，女性. 同期性収維があり diffuse esophageal spasm と訩断, 食道筋層切開を

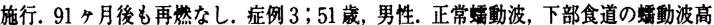
の增加があり nutcracker esophagus と䚷断し，硝酸凨を投与. 2 ケ月後も再燃なし. 症例 $4 ; 28$ 藏, 男性. LESP の上昇があり hypertensive LES と診断. LESP 上昇に対 し, バルーン拡張術を施行. 3ヶ月後, 再然の兆候がみられた. 症例 $5 ; 63$ 歳, 男性. 胸部中部食道における非期動波や振幅延長を認め, nonspecific esophageal motility disorder と考え，硝酸郕を投与. 6 ケ月後も再然なし. 結語; 食道内圧測定などの詳 絊な検査により，症例ごとに病態を把握し治療方針を検討する必要がある。

PPS-3-151 胸部食道虞に対する 3 領域郭清の評価と検討 坂本英至, 長谷川洋, 小松俊一郎, 広松 孝, 森 俊治, 德丸勝悟, 河合清貴，田畑智丈，深見保之

(名古屋第二赤十字病院外科)

【目的と方法】胸部食道摇に対する 3 領域郭清を再評価するために，72例を対象とし retrospective に検討を行った. (結果】リンバ節転移率は $U t(n=5)$ が頝部 40\%, 胸部 $60 \%$ ，腹部 $0 \%$ ，Mt $(n=46)$ が各々 35\%，43\%，33\%，Lt $(n=21)$ が $13 \% ， 48 \%$, $48 \%$ であった。次に䅡部転移陽性例 16 例 (Ut 2 例, Mt 12 例，Lt 2 例) について検討 した．転移部位は䅡部にのみ転移を認めた症例が 7 例と多くいずれも No101 のみの転 移例であった。頝部と胸部に陽性だったのが 3 例, 頝部と腹部のみ陽性だったのが 1 例，预胸腹いずれにも転移を認めたのが 5 例であった，頝部転移陽性例の予後を見ると 16 例中 9 例に再発を認め, 頝部再発は 1 例であった. 頝部転移陽性例の累皘 5 年生存 東は $27 \%$ と陰性例の $48 \%$ に比べ有意に不良だったものの，無再発長期生存例も2 例 あり,特に顏部単独転移症例 7 例の中では再発例は 1 例であった.ただし術後累皘生存 率は 2 領城郭清群と 3 領域郭清群の間に差を認めなかった. [結語] 生存率には差がな いものの，頝部単独転移症例に関しては郭清の意義は認められるものと思われた。

PPS-3-152 食道瘭に対する 3 領城リンパ節郭清の再評価 立花光夫，吉村寬志，田原英樹，タハールヂポック，柴北宗顥， 殿元康仁, 永末直文 (島根大学医学部消化器 $\cdot$ 一般外科)

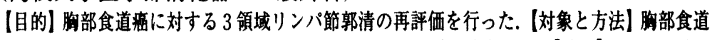

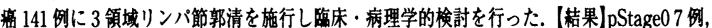
I 31 刿，II 51 例，III 29 例，IVa 23 例であった。 $\mathrm{pN}(+)$ は 70 例 $(50 \%)$ で, 平均リンバ節

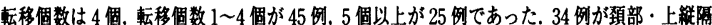
転移があり，その内 16 例 (11\%)が預部・上栍际転移のみであった。頝部りンパ節転移は維

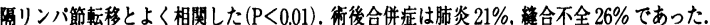
反回神経麻庫は $28 \%$ で,肺炎 30 例の内 8 例が神経麻模に起因したと考えられる. 3,5 年累䅡 生存事は $58 \% ， 48 \%$ ，無再発生存率は $73 \% ， 69 \%$ であった，累皘生存率の独立予後因子はり ンバ節転移橭数 $(<4 \mathrm{vs.}>5)$ ，輸血量 ( $<2 \mathrm{vs} .>3$ 単位 $)$ ，肺合併症の有無であり，無再発生 存事では、リンバ節転移個数，肉眼型分類 $(0,1$ 型 vs. 2,3 型)，占居部位 (Ut vs. Mt, Lt) て

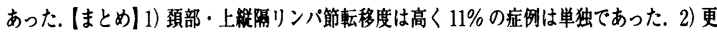
なる生存案向上には早期発見と術中出血量コントロール，術後肺炎軽減が重要である。 
PPS-3-153 食道竅に対する 3 領域リンパ節郭清の妥当性と限界 藤也寸志, 大賀丈史, 逗藤和也, 足立英輔, 相良安昭, 近藤 㣚, 知識真理子, 楠本宏記, 原口 勝, 岡村 健 (国立病院九州がんセンター消化器外科)

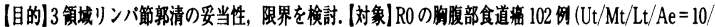

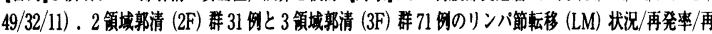

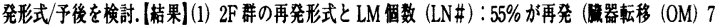

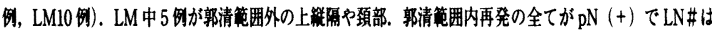

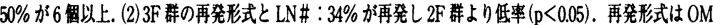

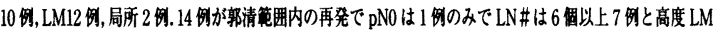

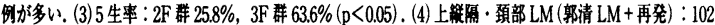

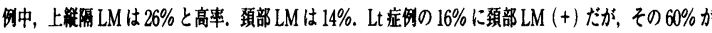

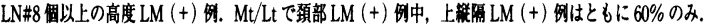

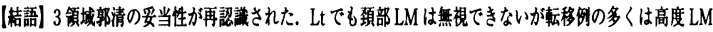

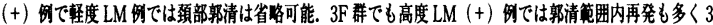

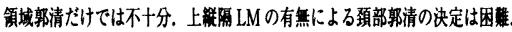

\section{PPS-3-154 食道癌 3 領域郭清施行後再発例の検討}

葉梨智子"，鈴木理香"，名久井実"，柏木宏之"，近藤泰理"，

千野 修" ${ }^{2}$, 島田英雄 ${ }^{21}$, 今泉俊秀 ${ }^{2}$, 小越章平 ${ }^{22}$, 幕内博康 ${ }^{21}$

(東海大学東京病院外科 ${ }^{1}$, 東海大学消化器外科学 ${ }^{21}$ )

3 領域郭清後再発例の検討から，郭清の暗応について検討した。对象：1994 年から 2003 年に当

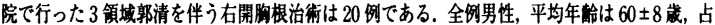

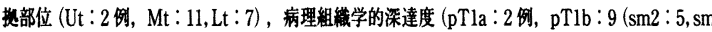
$3: 4)$, pT2：4,pT3：5)であった２例が術前リンパ節轱移により CDDP+5Fuによる術前化

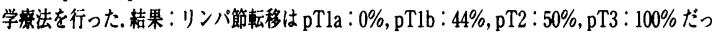

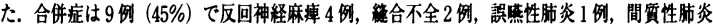

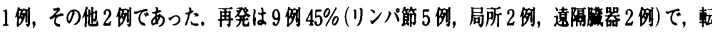

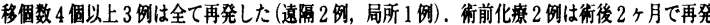

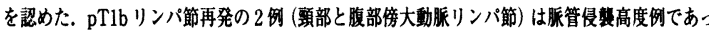

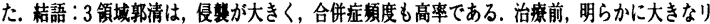

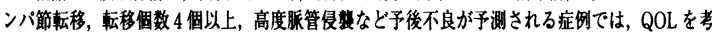

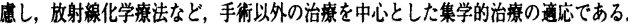

PPS-3-155 胸部下部食道, 腹部食道癌の頝部リンパ節廊清の意義 大賀丈史"，藤也寸志"，遠藤和也 ${ }^{11}$, 足立英輔"，楠本宏記"，

原口 勝", 岡村 健", 西山憲一2)

(国立病院九州がんセンター消化器外科 ${ }^{11}$ ，国立病院九州がんセンター病 理部 ${ }^{2)}$

(背景・目的) 食道癌治療の主体は外科治療であるが, 今回胸部下部・腹部食道瘭 のリンパ節転移状況の検討から手術内容を考察した. (対象) 1999 年から 2003 年 8 月までに行った食道癌根治手術症例 80 例中, 胸部下部 (以下 $\mathrm{Lt}$ ) と腹部 (以下 $\mathrm{Ae}$ ) 食道虞で右開胸にて食道切除し再建したのは 24 例, 6 例であった. (結果) $\mathrm{pN} 1$ 以上

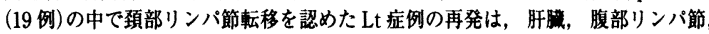
局所であった. Ae 症例では頚部リンパ節転移は認めなかった。一方で, $\mathrm{pN} 0(11$ 例)の LtAe 症例の再発は, 肺, 肝脿, 腹膜, 局所, 腹部リンバ節であった. 3 領域 郭清を行った Lt 症例の中で頴部リンパ節転移陽性例は，リンバ節転移個数が 8 個 以上と著明に多かった. LtAe 症例の 2 領域郭清症例においては䫋部りンパ節再発 を認めていない. (考察) 頚部リンパ節転移陰性の胸部下部食道癌には，局所制御及 び2 領域郭清を主眼とした手術を行い，䫋部郭清の有用性は低いと考えられた。

PPS-3-156 食道癌 3 領域郭清の見直し一術後頝部再発にたいするサ ルベージ・オペの有用性の検討一

平尾素宏, 藤谷和正, 增田慎三, 柏崎正樹, 池永雅一, 武田 裕,

三嶋秀行，沢村敏郎，辻仲利政

(国立病院大阪医療センター外科)

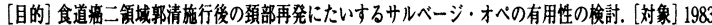

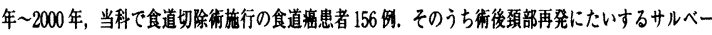

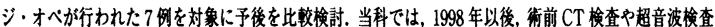

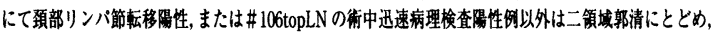

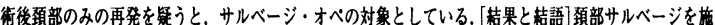

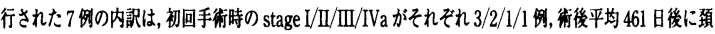

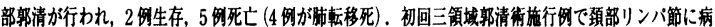

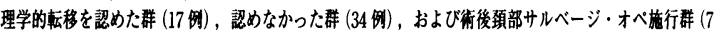

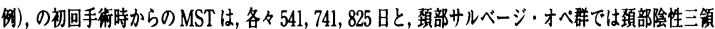

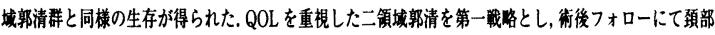
再発が筑われた時点でのサルベージ・オベでも十分な予後か得られ，その有用性が詪められた。
PPS-3-157当科における Salvage surgery の位置づけ 久原浩史, 木村正美, 有馬利明，井上光弘，西村卓旅，䖯野敬 (健康保険人吉総合病院外科)

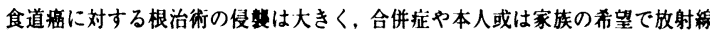
化学㫫法を選択する場合も多い. 当科では以前からインフォームドコンセント を基本に皘梗的に食道雷に対して放射線化学嶙法を初回治療として取り入れ

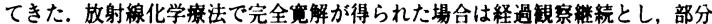
宽解の場合は根治手術を基本に治療方針を立てているか，無効や再発例に対し て化学療法を継続するか根治を求めて救済手術を選択するかが問題となる。手 術手技や器材の発達, 腫物学の発展により患性疾患に対して様々なアプローチ が可能とはなってきたが，瘦が全身病である以上治㫫は十分な情報が与えられ た患者本人及び家族の決断でなければならない。今回我々は 3 例のサルベージ 手術を経験したので報告する．いずれの症例もインフォームドコンセントの結 果救済手術の選択がなされたものである.放射線化学撩法後の手術において照 射野の密着が問題となるが、今回の自倹例では救済手術までの期間が短期で

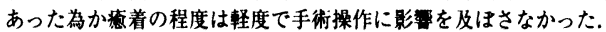

PPS-3-158 化学放射線療法後サルベージ手術施行進行食道瘦症例の 検討

青儀健二郎, 沖田充司, 栗田 敬, 高鴄成光

(国立病院四国がんセンター外科)

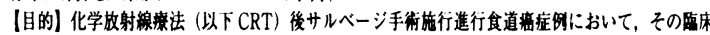

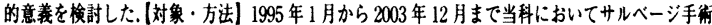

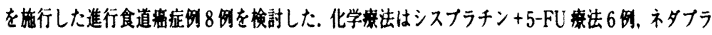
チン+5-FU 暴法 2 杋で、レジメンはシスブラチン $40 \mathrm{mg} / \mathrm{m} 2 \mathrm{dl}, 8$ または $80 \mathrm{mg} / \mathrm{m} 2 \mathrm{dl}$ (ネタタフ チン $90 \mathrm{mg} / \mathrm{m} 2 \mathrm{dl}), 5-\mathrm{FU} 400 \mathrm{mg} / \mathrm{m} 2 \mathrm{dl}-5, \mathrm{~d} 8-12$ または $800 \mathrm{mg} / \mathrm{m} 2 \mathrm{dl}-5$ の 2 サイクルで, 敬射

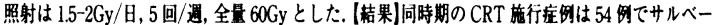

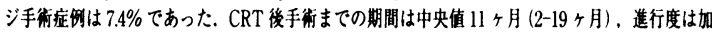

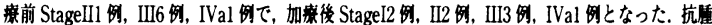

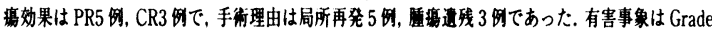

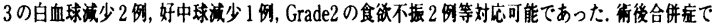

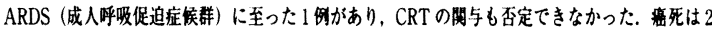

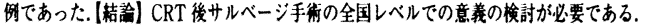

PPS-3-159 腹腔鏡下大腸切除術におけるクリニカルパスの有用性の 検討

米満弘一郎，杉原重哲，外山栄一郎，鶴田 豊

(社会保険下関厚生病院外科)

【目的】当科では腹璄鏡下大腸切除術（以下，LAC)に 2003 年よりクリニカルバス (以下, CP)を導入した，導入前と比较し，LACにおけるCPの必要性を検討した。 【方法】早期大晹瘭に施行した開腹下大晹切除例 20 例 (開腹群) と, CP 導入前 LAC 施行症例 64 例, CP 導入後 $\mathrm{LAC}$ 症例 14 例 (CP群) 对象とした. CP前 LAC 症例は施行順に（前期群）21 例，(中期群） 21 例，(後期群) 22 例に分けた。各群間 で術後水分開始日，術後食事開始日，術後入院日数を比较した. [CP内容]水分開始 は術後 2 日目. 食事開始は術後 4 日目. 追院は 7 9 日目. 【結果了街後平均水分開始 日は開腹群 5.25 日, 前期群 4.33 日, 中期群 3.71 日, 後期群 2.95 日, CP 群 2.3 日.

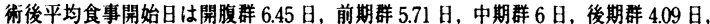
$\mathrm{CP}$ 群 3.98 日. 術後平均入院日数は開腹群 23.95 日, 前期群 23.95 日, 中期群 23.14

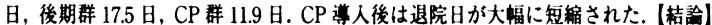
LACの利点である早期䢙院の実現に，CP 併用の必要性が認められた。

PPS-3-160 当科における腹腔鏡補助下大腸切除術クリニカルパスの 導入効果

中原雅浩，黑由義則，倉西文保，岡本住，豊田和㕕，高倉有二， 番匠谷将孝, 下村 学

\section{(厚生連尾道総合病院外科)}

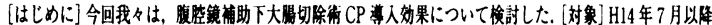

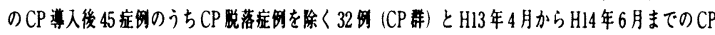

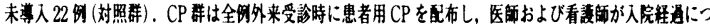

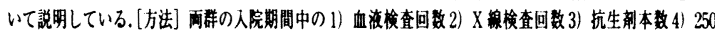

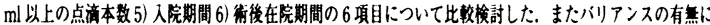

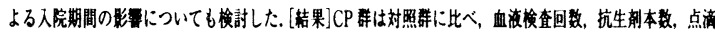

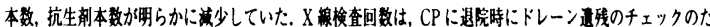
めX線撮影を行っているためCP群で增加していた. 入院期間は20.8日から13.0日へ，溨後在院期間し

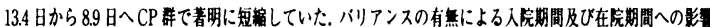

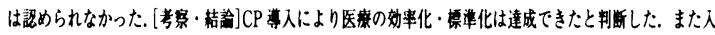

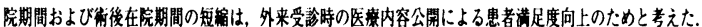


PPS-3-161腹腔鏡下大腸切除術におけるクリニカルパス 当科にお ける変倦と現状

吉川征一郎, 木所昭夫, 福永正氣, 射場钽明, 杉山和義, 福永哲, 永仮邦彦, 渡辺 䇣, 須田 健

(順天堂大学浦安病院外科)

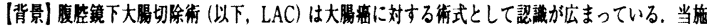

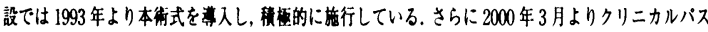
(以下 $\mathrm{CP}$ )を取り入れ，入院期間の短編，早期释口掑取を武み，腹肱鏡下手術の利点を生かすべく取

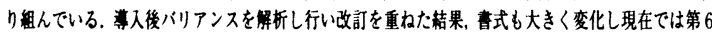

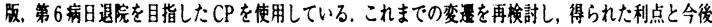
の䐂題について検討を行った.(方法】通用を開始した 2000 年 3 月から 2003 年 12 月までのCP施行

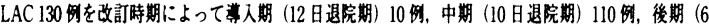

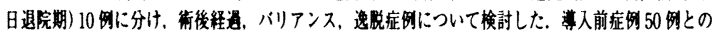

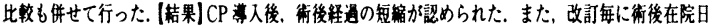
数は有意に短䑾しており，最新の改訂後に最も著明であった（結謧】CPの運用上，バリアンスの検

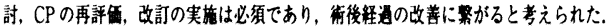

PPS-3-162 腹腔鏡補助下大腸切除術におけるクリニカルパスの検討 田平秀昭, 谷口和樹, 石黒めぐみ, 牧野博司, 岩瀬尚子, 角崎秀文, 植竹宏之, 安野正道, 梗本雅之, 杉原健一

(東京医科菌科大学大学院消化機能再建学)

【目的】 2002 年 3 月より腹胿鏡補助下大晹切除術症例に導入したクリニカルパス (以下 CP) に対して，䠦床，経済効果とそのバリアンスについて検討した. (対 象】 2001 年 5 月以降 2004 年 1 月までの 124 例が対象とし, 非施行群 33 例 (N 群) とバス施行群 81 例 (CP 群) とに分け prospectiveに検討した.【方法】CPでは，術 後 8 病日に退院となるように設定した． 統計処理には Mann-WhitneyのU 検定を 用いた【結果】術後在院日数の中央值について CP 群の 15.7 日は N 群の16日と比 㜞し，有意差は得られなかった。しかし術後保険請求点数は, CP 群と N 群は，各々 39171 点, 47506 点であり，CP 群で有意に術後保険点数が削娍出来た，術後 8 病日 以下で退院となったケースは $\mathrm{N}$ 群では無く $\mathrm{CP}$ 群では約 $27 \%$ (22 例)を占めた。 バ リアンスについては術後合併症によるケースが約 4 割と最も多かったがシステム 要因, スタッフ要因, 社会的要因をあわせると約 4 割とほは同数を占めた. 【まとめ】 $\mathrm{CP}$ 管理は，医丵費の削娍に有効であり，医尞の標华化に寄与すると考えられた。

PPS-3-163 大腸癌手術におけるクリニカルパスの適応と術後の攝食 開始時期の検討

渡部通章，高尾良彦，石山哲，牛込环郎，衛藤洋，小川匡市，

穴澤貞夫, 山崎洋次, 矢永勝彦

(東京慈患会医科大学外科)

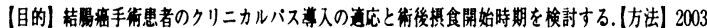

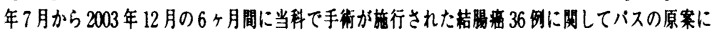

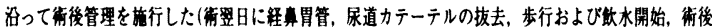

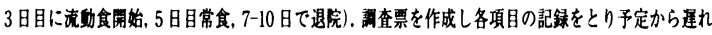

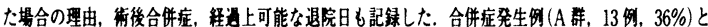

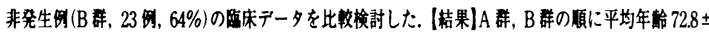

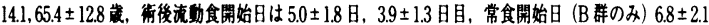
日目，簿後平均入院日数(退院可能日で草出)は $20.7 \pm 13.7,10.3 \pm 3.2$ 日，麻醉科PSは $1.7 \pm 0.6,1.8 \pm$

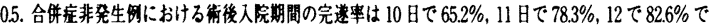

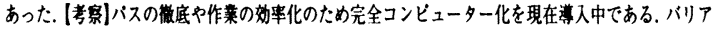

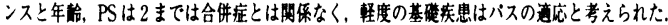

PPS-3-164 肛門疾患手術のクリニカルパス

楼崎和也"，秦 洋文"，金澤昌满"，野明俊裕"，井上明美"，

荒不靖三”，高野正博"，白水和雄

(大腸肛門病七ンターくるめ病院"1, 久留米大学外科 ${ }^{2}$ )

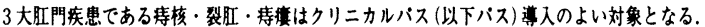
肛門疾患は症例が多く治廉方針は施設で確立しておりまたインフォームドコンセントの充 実の点で特に有用である，当院では庤核に肛門上皮乾部組檴温存の結紮切除街(閉鎖法)を， 寿搜にくり抜き法なとによる括䄪筋温存術を，裂肛に sliding skin graft 法を施行している. 患者説明用バスではイラストを入れ術後释通にて変更が生じることを理解してもらい不安 を事前に䂆防した．スタッフ用バスはアンケートをもとに現状の問題点の指摘と解決のため

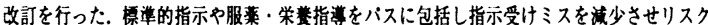
マネージメントにも役立った．3大奏患に加えて異なった治廉を行う疾患や病態に対応する ため計 10 種類のバスを作成し，またバリアンスの原因となる創部出血や創感染の誘因に硬 便や下乘があるため患者本人に便通日誌をつけてもらい排便コントロールをいち早く行っ

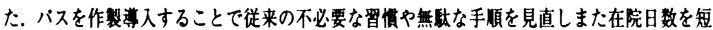

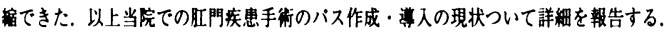

PPS-3-165当院における人工肛門造設手術の実態と管理 奥 邦彦, 西田幸弘, 宮崎 知, 中野博史, 岡 義雄, 伊豆蔵正明, 西嶌準 -

（東大阪市立総合病院外科）

く目的>人工肛門を要する疾患は未だ多いがその報告は少ない.人工肛門造設の 実態と管理につき検討した. 〈対象>1998 年から 2003 年における人工肛門造設患 者く結果>ストーマを造設した 151 例中男 87 例, 女 64 例で年龄は平均 64.4 墄. 大 腸が 143 例 (94.7\%) 小腸 8 例 (5.3\%)，永久が 94 例 (63\%)一時的が 57 例 (38\%) 緊急手術が 53 例 $(35 \%)$ 予定手術が 98 例 $(65 \%)$ ，単孔式 112 例 $(74 \%)$ 双孔式 39 例 $(26 \%)$. 背景は大腸癌が 100 例 $(66.9 \%)$ で切除不能癌が 55 例，根治術 45 例（全体の $29.8 \%$ )。聚急は穿孔 26 例，イレウス 12 例，䋖合不全 9 例，捻転 2 例，胃癌，春噵損傷各 1 例. ストーマは平均 $33 \times 28.8 \mathrm{~mm}$, 高さ平均 $6.7 \mathrm{~mm}$ だった。 合併症は高度狭窄 2 例, ストーマ周囲感染 1 例, 高さ $5 \mathrm{~mm}$ 以下のものに皮应症状 及び便漏れを多く認めた，〈結論〉直腸韵に対する永久的人工肛門は約 3 割と少 なく, 一時的や緊急での造設が 4 割近いのが害態である. 緊急においてもオストメ イトの QOL 改善につながる管理しやすい人工肛門の造設が必要である.

PPS-3-166 大腸癌手術におけるドレーンの有用性に関する検討 松本 隆, 齊藤直人, 山田正已, 利光靖子, 多賀 誠, 小川展二, 小澤修太郎, 宮澤光男, 篠塚 望, 小山 勇

(埼玉医科大学消化器 - 一般外科 (I))

【はじめに】下部直腸密を除く大腸密手術症例を，手術日で無作為にドレーン㨂入，非挿入 群に割り付けてドレーンの有用性を検討した. (対象と方法】2003年6月より2004年1月ま

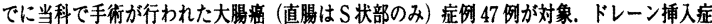
例 (D 群) は 23 例，ドレーンを挿入しなかった症例 (N 群) は 24 例. 両群間で術後合併症 を比較検討した。結果】1. 平均年龄，男：女比，占居部位，Stage，施行手街，郭清度なと の背景因子にドレーン挿入群, 非挿入群の間で差はなかった. 術中出血量, 手術時間も有意 差なし. 2.ドレーンは術後 2.9 (2-7) 日で抜去. 1 日ドレーン流出量は $152(60-611) \mathrm{ml}$. 3.術後合併症は，D群，N群それぞれ，創感染 $(13 \% ， 8 \%)$ ，イレウス $(4.3 \% ， 4.2 \%)$ ，小 晹穿孔 $(4.3 \%, 0 \%)$ ，大晹炎 $(4.3 \% ， 0 \%)$ で，小腸穿孔はドレーン抜去後の発症で保存的 に治等したためドレーンの有用性はなかった，4.食事開始日は D 群 : $2.4 \pm 1.1$ 日， N 群： $1.6 \pm 0.8$ 日でドレーン挿入群で有意に遅い.【まとめ症例数が少なくさらに今後の検討が必 要と思われるが, 下部直晹を除く大腸癌手術ではドレーンの有用性は少ないと思われた.

\section{PPS-3-167大腸他䑏器重複癌の臨床病理学的検討}

上島成幸"，仲原正明"，今分 茂"，赤松大樹"1，水谷 伸"1，

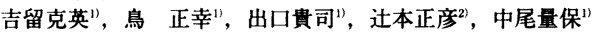

(大阪謷察病院外科" ${ }^{1}$, 大阪整察病院病理科 ${ }^{2)}$ )

近年, 社会の高龄化, 検査機器の精度向上により同時性, 異時性重複密が増加している.その中 で, 大腸と他䑏器重複湙症例について検討したので報告する.対象は 1991 年から 2003 年に当院

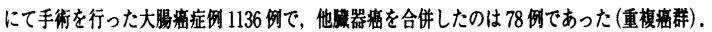
症例は，男性 59 例，女性 19 例，非重複整例では，男性 562 例，女性 380 例で，男性が有意に多

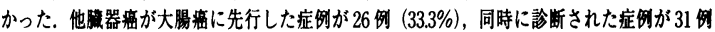
$(39.7 \%)$ ，後に診断された症例が 12 测 $(15.4 \%)$ ，不明 9 例であった。㗊別では，男性では胃

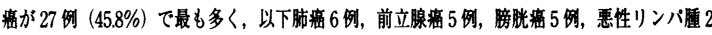

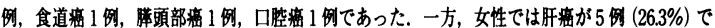

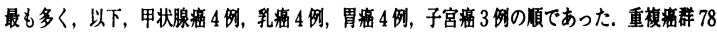

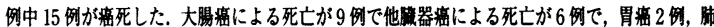

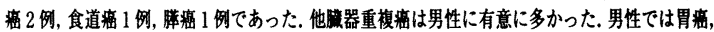
肺癌が多かったが，女性では甲状腺癌，乳癌が多く，経過铸察中に注意が必要と思われた

PPS-3-168大腸癌における同時性他腈器重複癌の検討 西上耕平, 池田陽一, 岸原文明, 矢原敏郎, 池尻公二, 才津秀樹, 朔 元則

(国立病院九州医療七ンター外科)

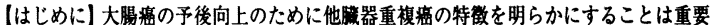
である. 今回, 大腸㾇における同時性他䑏器重複㾞について検討した. [対象および方法]

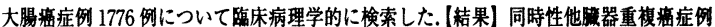

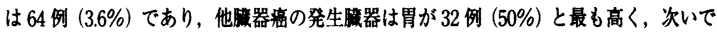

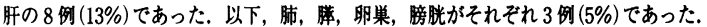
重椱癌症例 64 例と非重複癌症例 1581 例を検討したところ, 平均年跉は非重槙癌症例の

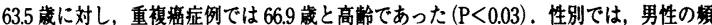

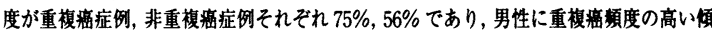
向が認められた $(\mathrm{P}<0.01)$ ．大腸癌の占樾部位，および組織型では有意差を認めなかっ た.【まと】大腸癌における同時性重槙癌の頪度は $3.6 \%$ であり，高龄者および男性に

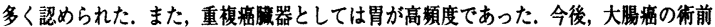
検査においては, 同時性他眼器重複癌の可能性を考虑することが重要と考えられた。 
PPS-3-169 異時性他腀器癌を重複した大腸癌症例の検討 岸原文明, 池田陽一，矢原敏郎，池尻公二，才津秀樹，矢加部茂， 朔 元則

(国立病院九州医療センター外科)

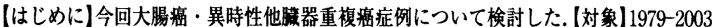
年の大晹癌手術症例 1776 例のうち異時性他脸器重椱癌症例 129 例と非重複癌症例 1581 例を比較し, 異時性症例の郜床病理学的に検討した. [結果]異時性症例/非重被症 例の年齢は 68.0/63.5 才で異時性症例が高龄であった。性別, 大腸海占掩部位, 組織型, Dukes 分類に差はなし．異時性他哭器重複癌の第 1 痹から第 2 癌発見までの間隔は平 均 11.0 年で，発見時期は他癌先行 86 例，大晹癌先行 43 例. 他癌は胃 47 例，子宮 20 例，乳腺 17 例，肺 11 例などであった。他癌先行例/大腸㾇先行例の比較では年龆 $69.9 /$ 64.2 才と他癌先行例が高齢で, 男性 $35 / 31$ 例，女性 $51 / 12$ 例と女性に他瘭先行例が多 かった．大腸癌占拠部位，組織型，Dukes 分類に差はなし．他癌先行例の他需は胃 31 例, 子宮 18 例, 乳腺 16 例などで, 大晹癌先行例の他癌は胃 16 例, 肺 10 例などであっ

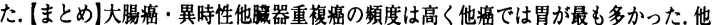
癌先行例では子宮, 乳腺の重複頻度が, 大腸福先行例では肺の重䙡頻度が高かった。

PPS-3-170 同時性多発大腸癌の臨床病理学的検討 岡本 健, 小林道也, 岡林雄大, 並川 努, 甫喜本憲弘, 杉本健樹, 荒木京二郎

(高知大学第 1 外科)

【目的】大腸癌を発見した場合，多発性癌を考慮することは重要である。そこで同時性多 発大腸癌の臨床病理学的検討を行った. (対象】1981 年 2003 年に切除された多発性大渴 痹 29 例. [方法] それぞれの)病変の部位, 進行度, 組織分化度および 1993 年以前 (前期) と以後 (後期) での症例数の変化を検討. (結果】 同時性 2 病変 26 例のうち右㒋大晹・左 㑡大腸に分類すると同一領域での存在は 21 例 $(81 \%) .2$ 病変とも早期痹 4 例 $(15 \%)$ ， 進行癌 11 例 (42\%)，早期癌・進行虚 11 例 $(42 \%)$ で，分化度が同一は 13 例 $(50 \%)$ で あった. 3 病変を認めた 3 例では同一領域での存在は 2 例 $(67 \%)$ ，早期癌 1 病変・進行 癌 2 病変が 2 例 $(67 \%)$, 早期癌 2 病変・進行癌 1 病変が 1 例 $(33 \%)$ で，分化度が同一 は1例 (33\%) であった. 前期 9 例 (31\%)，後期 20 例 (69\%) で後期に多く発見切除さ れていた. [考察]多発病変は同一領域に存在する傾向にあり内視鏡で大腸癌を発見した 場合,より慎重に近辺の粘膜の観察が必要であると考えられた。また進行度・組織分化度 からは, いわゆるスキップ病変というより多中心性の癌の発生が示唆された。

PPS-3-171ＨNPCC のサーベイランスで発見した径 $5 \mathrm{~mm}$ の腺腫内 $\mathrm{sm}$ 癌の 1 例

新井正美, 上野雅資, 佐藤貴弘, 大矢雅敏, 畦倉 蒸, 山本順司, 大山慗和, 関 誠, 山口俊晴, 武藤徹一郎

（癌研究会付属病院 消化器外科）

【症例】 55 歳 男性. [既往歴] 34 歳上行結腸癌にて右半結腸切除. 51 藏前立腺癌に

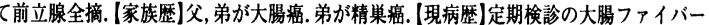
にて下行結腸に長径 $5 \mathrm{~mm}$ の1s 型ポリーブを認め, EMRを施行した. (病理所見)腺䭪内 癌で, 癌は高分化型腺癌 ly+, v一であった。溉方断端は陰性であったが，深部断端は晅 性で, 深達度は sm2 であった. 免疫組織染色では, hMSH2 のミスマッチ修復蛋白の欠損 を癌および腺腫の部位に認めた。 [開腹所見]HNPCC と䛦断し，残存結腸全摘術を施行し た. 術中, 腹膜播種, 肝転移, リン八゙節転移は認めなかった. (まとめ)HNPCCの大晹㿋 は坬発なため, 通常の大腸癌と同様の切除が行なわれ，術後にサーベイランスを行なう場 合が多い.しかし，一方では，腺腫から癌への進行が早いことが報告されている. 本例で も,腺腫の段階ですでにミスマッチ修復蛋白の欠損を認めており,サーベイランスの目標 として，小さな腺腫や過形成性ポリーブも重視すべきことが示唆された。

PPS-3-172 遗伝性非ポリポーシス大腸癌の遺伝子診断 一癌の遗伝 外来における最近の症例から-

佐久間威之", 野水 整 ${ }^{1.23}$, 宮本康太郎 ${ }^{11}$, 小林恵子" ${ }^{11}$, 山田睦夫 ${ }^{11}$, 片方直人 ${ }^{12}$, 渡辺文明"，関川浩司 ${ }^{32}$ ，竹之下誠一 ${ }^{3 !}$

(星総合病院外科 ${ }^{1}$, 星総合病院癌の遺伝外来 ${ }^{2}$, 福島県立医科大学第 2 外科 ${ }^{31}$ )

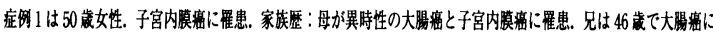

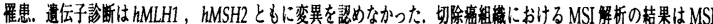

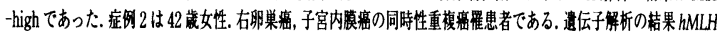

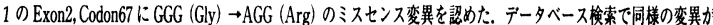

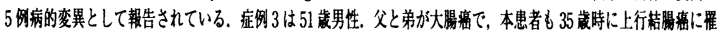

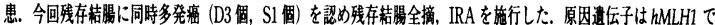

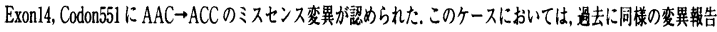

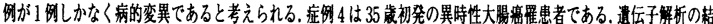

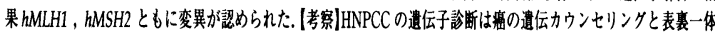

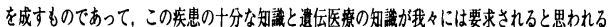

PPS-3-173 散発性の癌における塩基除去修復因子の異常 伊藤 淳, 竹林勇二, 苜䗁敦子, 竹之下誠

（福島県立医科大学第 2 外科）

塩基除去修復因子の機能不全は，遭伝病であり，日光照射部位の皮漂の発生危険度が 著しく增す色素性乾皮症 (xeroderma pigmentosum；XP) として知られている. しか

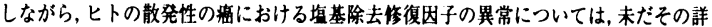
細は明らかでない，坦基除去修復因子の異常の，散発性の毒に対する影策を検討する目

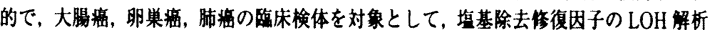

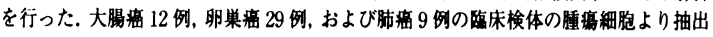
したゲノム DNAを用いて，埴基除去修復因子である XPA，XPB，XPC, XPD, XPE， XPF，XPG 遗伝子および Cockayne syndrome B (CSB) 遭伝子の LOH 解析を，PCR

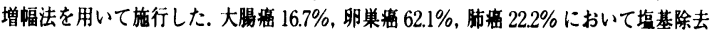

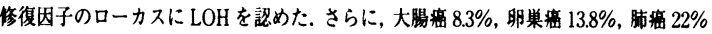
は, p53やFHIT, APC, BRCA1，BRCA2, DCCなどのがん㧕制遗伝子の LOHは認め られず，塩基除去修復因子をコードする道伝子のローカスのみにLOHを認めた。本研 究により，ヒトの散発性の瘦において塩基除去修復因子の異常が明らかとなった。

PPS-3-174 大腸踝肺転移症例に対する肺切除の検討

宮本裕士, 山口達郎, 森 武生, 高橋慶- - , 松本 寛, 宮本英典, 党井邦佳，岩崎善媇、片柳 創

(東京都立駒込病院外科)

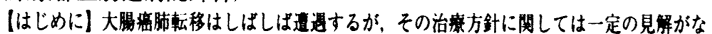

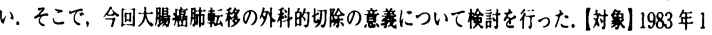

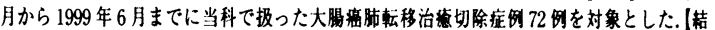

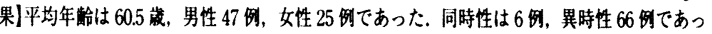

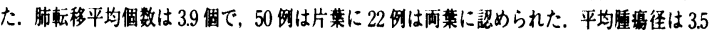

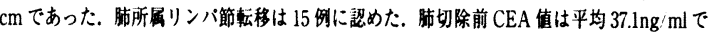

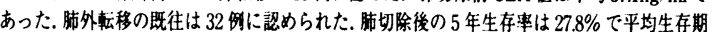

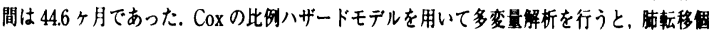

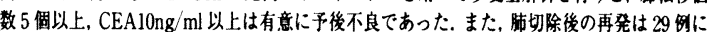

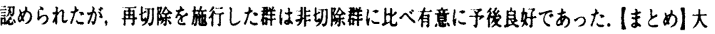

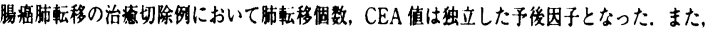
肺切除後の再発に対しても皘梗的な外科切除仙子後延長を期待できると示畯された

PPS-3-175 大腸癌肺転移症例の検討

五代天偉"，山本直人"，塩澤 学"，赤池 信"，杉政征夫", 武宮省治"，今田敏夫"'

(神奈川県立がんセンター消化器外科", 横浜市立大学消化器族センター”' 【目的】大腸㾂肺転移症例について臣麻病理学的に検討した.【対象】1982 年か ら 2003 年までの当科における大腸癌肺転移症例 164 例(同時性 59 例，異時性 104 例). 当科では肺転移に対し，根治を得られる症例に对しては切除の方針と している. (結果)大晹数肺転移症例 164 例の 5 年生存事は $24 \%$ で, $50 \%$ 生存 日数 (Median Survival Time：MST) は 30 ヶ 月であった。予後因子を模討し た粘果，統計学的有意差を認めたのは, 肺切除, 肝転移の有無, T4 以深であっ た.この内, 肺切除を施行した 35 例での 5 年生存事は $57 \%$ で, MST は 68.2 ケ月であり，有意に生存期間の延長を認めた。また，大晹密術後の異時性肺单 独初再発例 51 例のうち, 肺切除 26 例に対して子後因子を検討した結果, 有意 差を認めたのは初回手術時の根治度 A と B の間であった。 【まとめ】大晹落肺 転移症例に対する肺切除は生存期間を延長させ，予後に大きく関与すると考 えられた．また，肺切除後の子後规定因子は原発巣の病期であった。

PPS-3-176 長期生存例から考察した大腸癌肺転移の手術適绾の再检 討

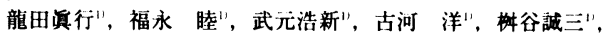

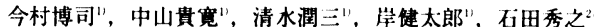
(市立堺病院 ${ }^{11}$, 大阪船員保険病院外科 ${ }^{2}$ )

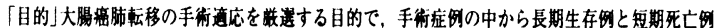

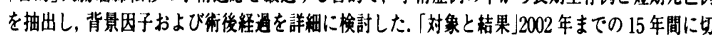

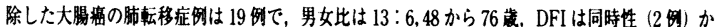
56 年 9 月 (中央值 1 年 11 月)。全体の 5 年生存事は $50.2 \%$ で, 4 何 (長期群) は 5 年以上等再

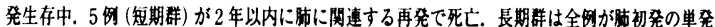

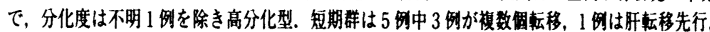

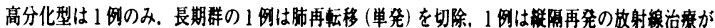

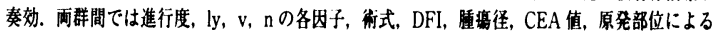

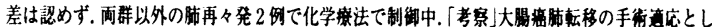

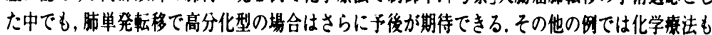
考慮寸る必要がある，術後経通中の再々発に対しても皘梗的な治瘄仕有用である。 


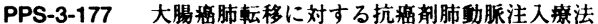
村田幸平"，能浦真吾"，宮代 黙"，山田晃正"，土岐鿆一郎"， 大東弘明"，佐々木洋"，龟山雅男"，石川 治"，今阙真義" (大阪府立成人病センター外科", ベルランド総合病院外科"') 目的：再発大晹素の中でも肝転移に対しては切除及び肝動注が普及し効 果を上げているが, 肺転移に対しては手術以外の局所撩法がない. 肺の局 所化学療法として, 肺動脈に cannulation しバルーンで flow を止めて抗㾇 剂を注入する方法 (肺動注)を開発した。本法の安全性を確認するために

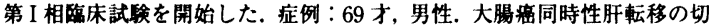
除後 2 年 9 ヶ月目に肺転移 (左 S5, 径 $10 \mathrm{~mm}$ ). 左肺動脈起始部にてバルー ンを部らませ CDDP $15 \mathrm{mg} / 40 \mathrm{ml}$ を注入し， 30 分間バルーンを留置した。 血中菜物動態では，バルーン解放後の末梢ブラチナ漫度の上昇を認め，肺 内に CDDP が停滞していたことが判明した。 バルーン開放後も有害事象 はなく，3 週間後に安全に部分切除を行いえた。結論：大腸繰肺転移に対 する局所燎法としての肺動注療法は，新しい治撩法として期待できる．今 後安全性が確認されれば切除不能症例に適応を広げていく予定である。

PPS-3-178大腸癌再発の病態からみた危険因子と外科的治療（第 2 報)

横山 登, 島田恵太, 井上達史, 相田貞継, 田中孝幸, 山形健一, 增尾光樹，清水浩二，熊谷一秀

(昭和大学豊洲病院外科)

【目的】大腸盘再発で肝，腹膜転移は予後を左右する危険因子であり， 転移形式の機序について動物実倹，臨床材料から癌再発治療を再構筑し たい.【対象・方法】ラットのリンパ管閉塞モデルを作成し，虽光標識の 移行動態を検討した. 大腸籍切除 552 例のリンバ節外浸潤を検討し, 腹 膜再発切除 48 例の病理学的検討を行った. 【結果】ラットのリンパ管造 影では，末梢の広籁な逆流，蛍光細胞の出現，門脈交通を認めた。臨床 例で雨転移ともリンパ節外浸洞陽性と関連していた．腹膜再発切除例で

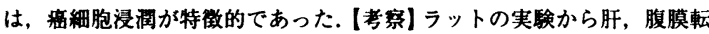
移を形成する可能性が考えられた。烸床例にて節外浸潤は再発の高危険 因子であり，再発切除例の検討から外科的治療は予後の改善が期待され た.

PPS-3-179 LV/5FU + CPT-11 動注化学潦法が奏功した進行再発大 腸瘭の 2 例

田原光一郎，荁島寬人，江口英利，安田一弘，简井信一，東 秀史， 武藤庯一

(国立別府昺院外科)

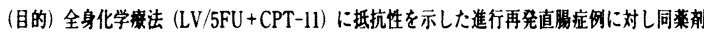

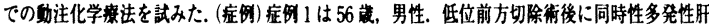

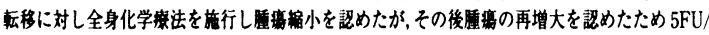

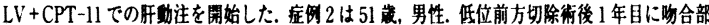

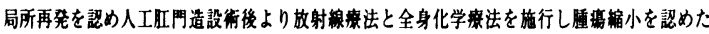

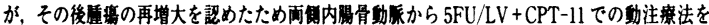

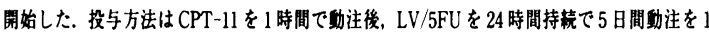

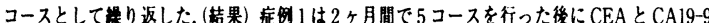

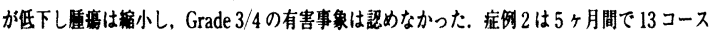

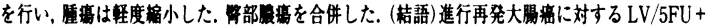

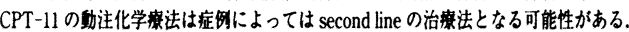

PPS-3-180 転移性肝㾇に対する治燎：CPT-11/5FU/1-LV 化学㙩法 の経殹

山田秀久"，森田高行"，藤田美芳"，宮坂祐司"，仙丸直人”， 押切太郎"，加藤紘之"

(北海道消化器科病院外科", 北海道大学大学院腫被外科")

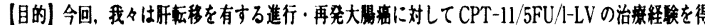

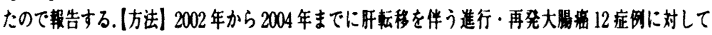
CPT-11: $100 \mathrm{mg} / \mathrm{m} 2$ (day 1, 15)， $1-\mathrm{LV}: 250 \mathrm{mg} / \mathrm{m} 2.5 \mathrm{FU}: 500 \mathrm{mg} / \mathrm{m} 2$ (day 1,8, 15,22) 6 通每を

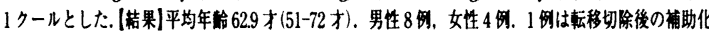

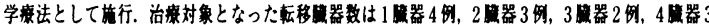

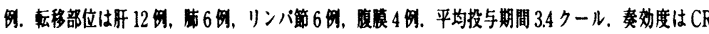

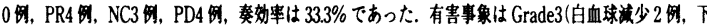

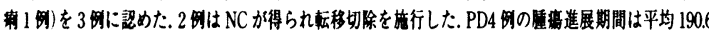
日 (99-300日) であった。現在までの生存期間は平均243.8日（147-343日）であった。溚部] CPT

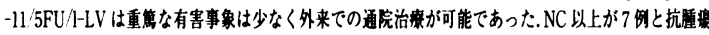

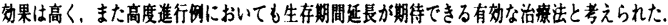

PPS-3-181 放射線・化学療法（CPT-11/LV/5-FU）が著効した Colotic cancer $の 1$ 例

兒玉英謙，今村幹雄，成島陽一，㐘地 秀

(国立仙台病院外科)

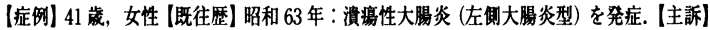
血便. [現病歴] 平成 15 年 3 月の大腸検査で，Ra〜Pに全周性の腫痹を認め，低分化型腺

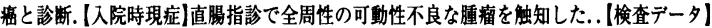
CEA33.5ng/ml, CA19-9 578U/ml (画像所見) MRI で骨整腈全体を占める巨大な腫音を 認めた。腹部 CTでは肝 S3に㧓立性転移を認めた。骨整脂に多発性骨転移を認めた。手 術所見]原発坚は切除不能であった，濽場性大腸炎を合併していたため大晹要全摘・回腸 隻造設を，孤立性の肝転移に対して肝部分切除を行った。術後経過】アイソボリン $(350$ mg) $/ 5-F U(850 \mathrm{mg})$ を週 1 回, CPT-1130mg を週 2 回投与の化学寮法, および全骨篮

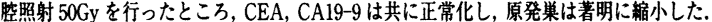
骨転移单は不変で, 新たな胿転移宩の出現も認めなかったため, 再手術を施行. 原発巣の 他識器への浸淍は認めず切除可能であった［考察】今回，切除不能な Colitic cancerに対 して放射線・化学㙩法が著効した1例を経絤したので，文献的考察を含めて報告する

PPS-3-182 Rb 直腸癌に対する局所切除の可能性

能浦真吾"，村田幸平"，刍山雅男 ${ }^{2}$ ，石川 治"，佐々木洋"，

大東弘明", 土岐祐一郎", 宮代 熟", 山田晃正", 今岡真義"

(大阪府立成人病七ンター消化器外科"，ベルランド総合病院外科 $\left.{ }^{21}\right)$

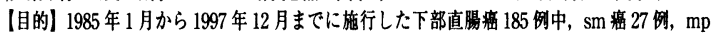
癌 33 例の計 60 例を対象とし，局所切除の可能性について模討した，した. $1 \mathrm{sm}$ 癌解析和果l27 例中 21 例 $(78 \%$ ）にリンパ節部清を伴う手街が巽択され，局所切除は6例のみであった、リン 八節転移は 21 例中 1 例 $(5 \%) に$ に認められた，リンバ節再発仙認めず，局所切除を施行した 1 例に畅合部再発をきたしたが salvage 手街が可能であった. Imp 毫解析結果】 33 例中 31 例

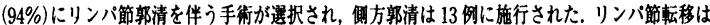

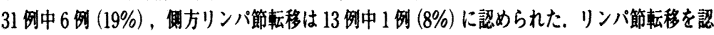
めた症例は，肉眼型では 1 型が1例，2型が 3 例，3型が 3 例，最大径では $20 \mathrm{~mm}$ 未满は1 例，

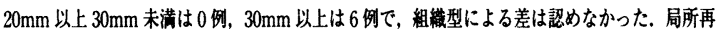

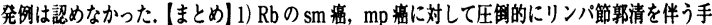

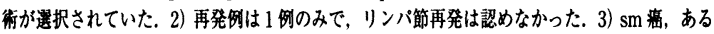

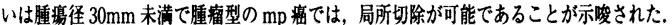

PPS-3-183 直腸稳に対する肛門温存療法の治療戦略 松本昌久, 丸田守人, 前田耕太郎, 花井恒一, 佐藤美信, 升森宏次, 小出欣和

(藤田保健衛生大学第 4 消化器外科)

【目的】近年，超低位の直腸艘に対してQOL，肛門温存のために subtotal-ISRを行っている が，本術式の適応や術後機能について，従来我々が工夫してきた術式と比較検討した！対象

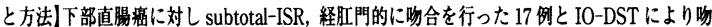
合を行った 31 例を刘象とした. 平均年柃は 58 歳, 男女比 $32: 16$ であった. 近門温存の道応 は，分化癌で腫倣と齿状線の距部が，術前深達度 MPで $1 \mathrm{~cm}$, それ以深で $2 \mathrm{~cm}$ 確保できる症

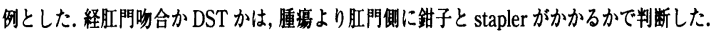
術後排便機能は，術前と stoma 閉鎖時に肛門内圧検查を行い，肛門管最大静止圧，生理的怔

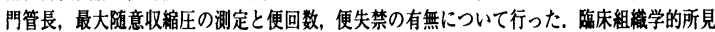
は，術前の AV，伆合部の距離，標本上の aw，維合不全率，局所再発率について検討した。 (まとめ) subtotal-ISR において MRP 值 HPZ 值と便回数で有意差を認めたが，便失禁の頉度

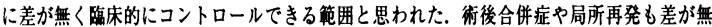
く, subtotal-ISR, 経胿門的吻合により，さらに低位の癌にも肛門温存が可能となった。

PPS-3-184 当科で経験した直腸腫湟局所切除 5 症例の検討 重田匡利，原田栄二郎，折田雅彦，榎 忠彦，野島真治，濱野公一 (山口大学第 1 外科)

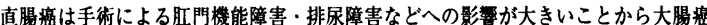

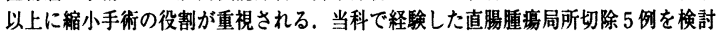

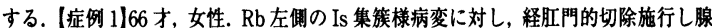

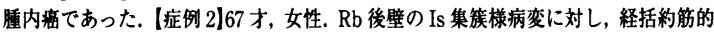
切除施行し高度異型腺腫であった（症例 3 ) 77 才，女性. Rb 左例の IIa+IIc 病変に 対し, 経仙骨的切除施行し高分化型腺癌, sm2, lyl, v0 であった. [症例 4] 57 才, 男 性. Ra-b右僛の Isp 病変に対し, 経仙骨的切除施行し高分化型腺㿋, m, ly0,v0 であった. (症例 $5 / 54$ 才，女性. Rb-P前壁のIs 病変に対し経括䄪筋的切除施行した. 病理で低分化型腺㿋, sm, ly2, v0であった。 症例 5 は遠隔リンパ節へ再発したが骨 整内への再発はなかった。またその他の症例では現在まで再発は認めていない。適応 は限られるものの直腸腫要に対する局所切除は十分なマージンを付忛全層切除可能 であり内梘鏡的切除困蜼な病変においても，それのみで根治性がある症例が少なか らす存在する，術後経過良好で大きな機能障害もなく有用な術式であった。 
PPS-3-185 直腸カルチノイド 26 症例の検討 羽生田信子, 古㟃 蒹, 奈良智之, 野家 環, 伊藤 契, 針原 康, 小西敏郎

(NTT 東日本関東病院外科)

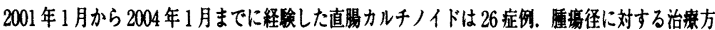
针の選択を検討した. [検討症例の内訳] 男女比は $20: 6$ 人, 平均年龄 48.9 藏. 存在部位は直腸 S 状部 4 人，上部直腸 9 人，下部直腸 13 人. [治㙩]内視鏡的切除 (EMR) 10 人．うち断端陽性にて

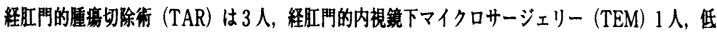

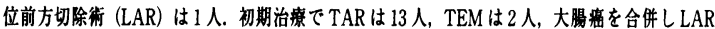

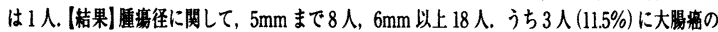
合併あり。腫場径 $6 \mathrm{~mm}$ 以上の 18 人中 11 人 $(61.1 \%)$ で $\mathrm{sm} 2 / 3$ 以上, 9 人 $(50 \%) に \mathrm{v}(+)$ を

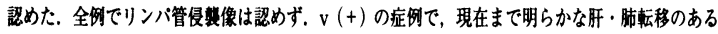
症例は磼誈されていない.[結論] $\mathrm{sml} / 3$ までは, EMR が可能と判断すると $6 \mathrm{~mm}$ 以上の症例では 断端陽性の確率が高くなり追加切除を必要とすると考えられる. 当院では, TAR・TEM とも合併 症が少なく, 全層切除も可能であり, LAR と比べ術後の機能不全を認めないことから, $6 \mathrm{~mm}$ 以上 でリンパ管侵襲像を認めない症例では，TAR・TEMを積極的に施行し得ると考えられる.

\section{PPS-3-186 放射線誘発直腸癌の検討}

田中雄悟, 池永雅一, 三嶋秀行, 柏崎正樹, 增田慎三, 武田 裕, 平尾素宏, 藤谷和正, 沢村敏郎, 辻仲利政

(国立病院大阪医療センター外科)

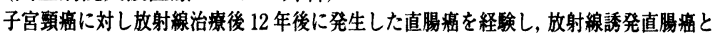
考えられる症例について検討し報告する，症例は 69 歳女性. 主訴は便柱狭小，血便。

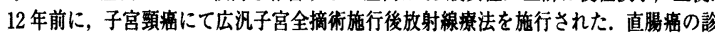
断で,ハルトマン手術を施行した. 病理組織所見は, 中分化腺癌, se, ly $0, \mathrm{v} 1, \mathrm{n} 0$, stageII,

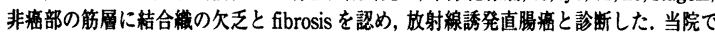
の全大腸癌症例 3800 例中, 子宮症が先行した大腸癌は 32 例. 子宮頚癌に対し放射線照 射施行した直晹癌は 8 例. この 8 例について検討すると, 平均年龄が 71.1 歳, 発生部 位は 1 例が Rs，2例が Ra，4例が Rb，1 例が Rp であった. 潜伏期間は平均 16.8 年 (2 31 年)で, 5 年以上が 6 例. 肉眼型は 5 型が 4 例であった。 病理組蟣像は, 4 例が 高分化腺密， 2 例が中分化腺癌， 2 例が粘液癌であった. 全症例で放射線照射によると 考えられる直腸炎の症状を認めていた. (まとめ)悪性腫瘍の放射線治療後は, 放射線誘 発瘦を念頭に置き，長期サーベイランスを行うことが必要である.

PPS-3-187 PPS-1-284の次に移動
PPS-3-189 複雑痔瘄 (脿場) に対する Strategy -ジャックナイフ位

MRIの試み-

宮崎道彦"，加川隆三郎"，友井正弘"

(洛和会音羽病院大晹肛門科"，洛和会音羽病院放射線科 ${ }^{2}$ )

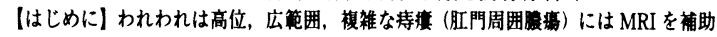
診断として活用している. 今回，より理解がし易いようにMRIの掫影法に工夫を加え

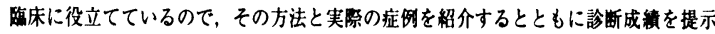

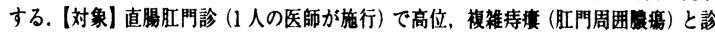

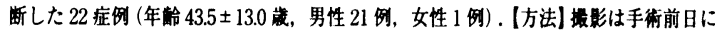
施行.まず掫影体位は腹卧位とし下腹部に枕を挿入し，手術体位であるジャックナイフ 位に近い体位とし，殿裂を広げるようにテーブで固定する.スライスは恥骨・尾骨線に 平行な面とそれに垂直な面 (冠状断に近い面)の 2 面のスライスを掫影する。診断には T2 強調画像を用いた. [診断耛果】本 MRI 掫影で診断された（1 人の放射線科医が診

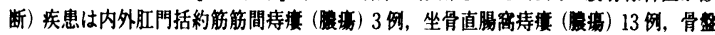

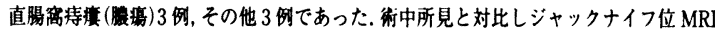
撮影の正診事は $86.4 \%$ （直晹肛門診正診事 $59.1 \%$ ）と非常に高かった.

PPS-3-190 内視鏡的静脈穜造影下硬化㫫法（EVIS）が奏功した直晹 静脈瘤の 2 例

王 孔志, 竹内雅春, 城 大介, 平川一秀, 藤元治朗

(兵庫医科大学第 1 外科)

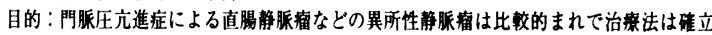

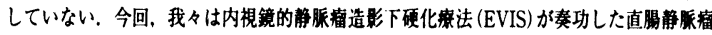
の 2 例について報告する. 对象および方法：2 症例ともに開腹手術歴および食道静腺菌の

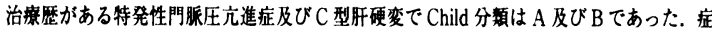

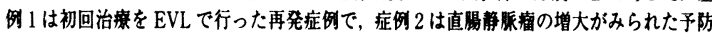

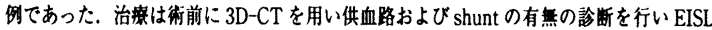

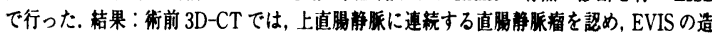

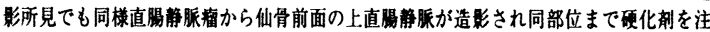

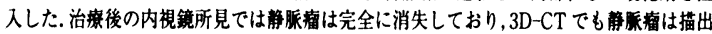
されず消失していた，症例 1,2 ともに街後16 ケ月及び12 ケ月経道しているが再発してい

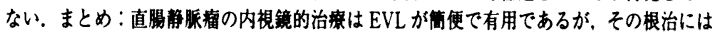
血行動態を十分に把暒したうえで EVISを行うのが最も奻果的であった。

PPS-3-191緊急䊅晹・直晹切除症例の術後合併症の検討 阿部恭久", 笹川真一", 指山浩志", 飯塚 浩", 雨宮志保", 落合武德"

(公立長生病院", 千荣大学大学院先端応用外科")

晹管执張の場合術中に可及的腸管内娍圧と，腹膜炎の場合術後皘柾的な呼吸管理を中心に

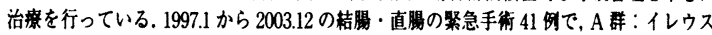
13 例，B 群：腹膜炎 28 例を対象とし，術後早期・後期 (7 日目以降)の合併症を検討した。

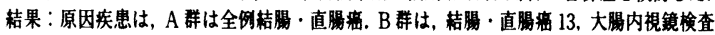

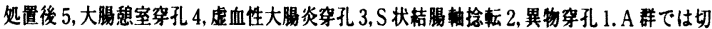

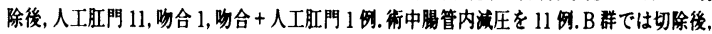

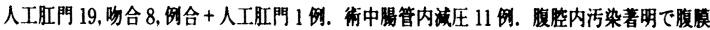
筋層の一層腹壁閉鎖を 12 例に行った. $\mathrm{A}$ 群では呼㖟器障害 2 , 㡒嫄不全 2 约で何れも軽 度. 後期では尿路感染 2, MRSA 晹炎 $1 . B$ 群では呼吸器障害 22 例で人工呼㖟管理を術

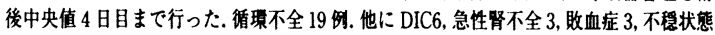

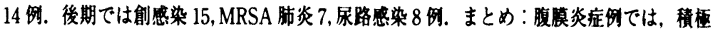
的呼㖟管理で良好な経通を得たが，後期の感染対策が今後の課題である.

PPS-3-192 直腸癌手術後䋖合不全症例の検討

森 和弘, 牧野 博, 小林隆司, 村岡患 - , 竹山茂

(黒部市民病院外科)

【はじめに】当科で経験した直晹軜術後䋖合不全症例について検討しその対策につ いて考察する.【対象】過去 6 年間に当科で経験した直腸症手術症例は116例で あった，今回の検討では，高位前方切除術および低位前方切除術が施行された 77 例を対象とした.【結果】術後に䋖合不全を発症した症例は，10例（13.0\%）であっ

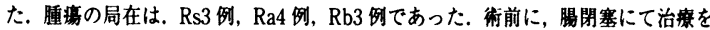
要した症例は認められなかった. 吻合法は, layer to layer が1例で他の 9 例は器械 吻合であった. stage は 1 が1例, 2 が 3 例、3aが 4 例, $3 \mathrm{~b}$ が 1 例, 4 が 1 例であっ た. 維合不全発症日は平均 8.9 日であった. 保存的に軽快した症例は 8 例であった.

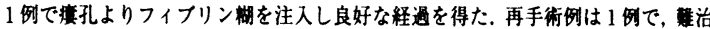
性瘦孔となり人工肛門造設術を施行した.【まとめ】(1) 直䤚稻術後の合不全は,

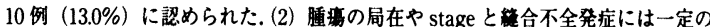

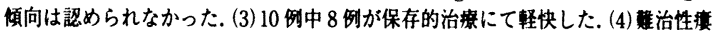
孔を形成した 1 例でフィフリンン糊を使用し良好な経通を得ることが出来た。 


\section{PPS-3-193 直晹前方切除術において術者の経倹が短期子後に与える} 影雴

飯野年男, 藤田明彦, 山形哲也, 諏訪勝侻, 三浦英一朗, 古川良幸, 高尾良彦, 穴澤貞夫, 山绮洋次, 矢永勝彦

(東京慈恵会医科大学外科)

く目的〉前方切除術は Colorectal surgery のなかで比較的歏易度の高い手術のであ

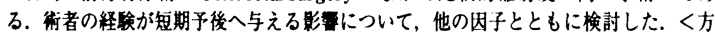
法>1997-2002 年に缶恵医大学第 3 病院で施行された前方切除術 86 例を対象. <結

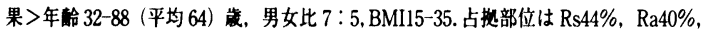
Rbl6\%．衍はHAR28\%，LAR72\%，伆合法はDST77\%．Stage は113\%，249\%， $3 \mathrm{a} 22 \%, 3 \mathrm{~b} 4 \%, 413 \%$. 根治度は A $86 \%, \mathrm{B1} \%, \mathrm{Cl} 3 \%$ 。手術時間は $100-415$ (平均

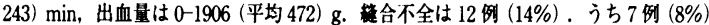
は Covering colostomy または ileostomy が既設. 術者経験あるいは大晹疾患班所属で あるかと，合不全の発生頪度に有意な関連はない，術後晹閉塞症は7 例 $(8 \%)$. 術後 在院日数は 12-150日，〈耛誝>今回検討した箅囲では，経験豊富な外科医が手術チー 厶内にいる㻴境下では，術者の経験が短期予後へ与える影需は認められなかった。

PPS-3-194進行下部直腸癌手術における術前放射線照射の有効性一 術後合併症と術後機能に着目して一

釣田義一郎"，渡臬聡明"，武藤徹一郎"2，小室安去"1"，清松知充"， 名川弘一

(東京大学 腫疸外科"，瘦研究会族院外科 ${ }^{21}$ )

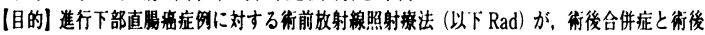
機能に及はす影箒を検討. (方法1 1990 年1月-1999年 12 月に手術を施行した進行下部直腸癌 庭体のうち，術前故射線照射を梅行した症例（以下 $\operatorname{Rad}(+)$ 群, $\mathrm{n}=102)$ ，及び術前診断に て深達度が MP'であったため Radを施行しなかった症例（以下 MP 群， $\mathrm{n}=20$ )の2 群間にお

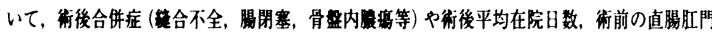

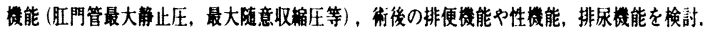
【成嘖】(a)画群間において，術後合併症の颊度や陠後の平均在院日数に差は認められなかっ

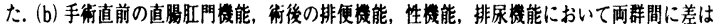

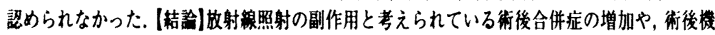
能障害の増加は認められなかった：したがって，進行下部道腸盘の治療において，術前放射線

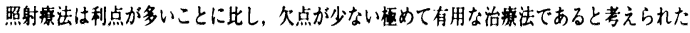

PPS-3-195 大晹手術における著着防止シート(七プラフィルム $\left.{ }^{\mathrm{TM}}\right)$ に よる術後イレウス防止効果の検討

安宅正幸, 牧野正人, 谷田 孝, 尾崎 舞, 大井健太郎, 中村誠一, 貝原信明

(鳥取大学第 1 外科)

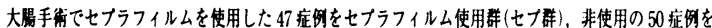

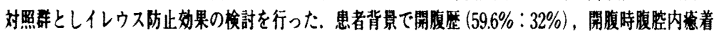

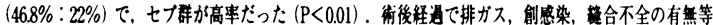
を比较したが差はなかった. 整後30日以内発症の早期イレウス症约は，七フ群で $13.7 \%$ と対照群の 6\%より高事であり，後期イレウス庭伆は七フ群で $2.1 \%$ と対照群の $8 \%$ より低事だったが，共に有意

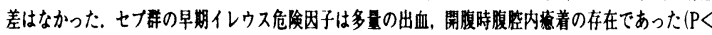

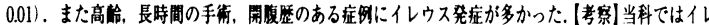

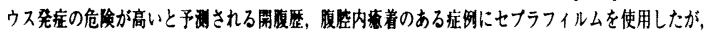

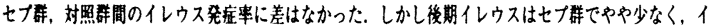
レウス老症防止に奇与すると考えられた，早期イレウス症例の検討からイレウス発症の危険因子を 持った症困は，たとえセフラフイルムを使用してもイレウス発䬺のリスクは高いと考えられた。

PPS-3-196直腸瘦術後の排便障害に対するポリカルボフィルカルシ ウム投与の有用性

石山元太郎"，秦 史壮"，古畑智久"，西森英史"，前佛 均"，

福井里佳"，平田公一"，八十島孝博"，佐々木一晃 ${ }^{3}$

(札幌医科大学第 1 外科 $"$ ，札㹸垁新病院 ${ }^{21}$ ，道都病院外科 ${ }^{31}$ )

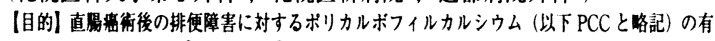

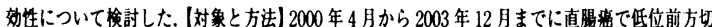

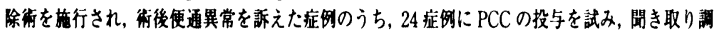
查を行った，PCC は 1 日量 $3.0 \mathrm{~g}$ を 3 回に分け一毎食後投与し，排便回数，便性状，腹部症状に

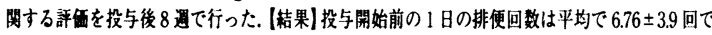
あったが, 8 週後の平均では $4.74 \pm 2.4$ 回と排便回数の改善を認めた. 便性状の改善事は $64.7 \%$, 改善㑯向まで含めると (以下改善㑯向率) は $82.3 \%$ であった，腹部症状の改善事は $33.3 \%$ ，改善

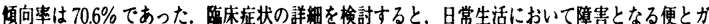
スの区別不能や残便感といった症状において高い改善頃向が認められた。また，投菜時期や性別 による改善度に有意な差は認められなかった。格詥]PCC は低位前方切除街後の便通異常に対 して，排便回数，便性状，腹部症状のいずれにおいても有奻であると思われた。
PPS-3-197直腸癌術後難治性瘦孔に対する経肛門的瘦孔部綎合閉鎖 術による治療経験

菅本祐司"1, 小澤弘侑", 飯野正敏" , 木村正幸"1, 福長 徹",

河野世章 ${ }^{1}$ ，青柳智義"，武ノ内史子 ${ }^{11}$, 落合武徳 ${ }^{21}$

(沼津市立病院外科 ${ }^{1}$, 千葉大学大学院先端応用外科学 ${ }^{21}$ )

47 歳男. 直腸翻に対し低位前方切除を施行. 退院後の第 23 病日に伆合部背㑡の痛みを主訴に外来受

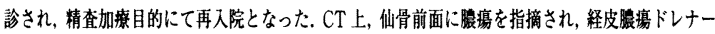

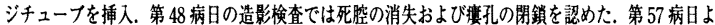

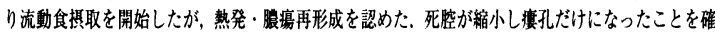

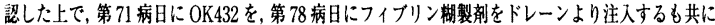
完治せず、第 118 病日に直視下に瘦孔部の腸管粘膜側からの䋖合を陚みたが, 吻合部周辺の視野の

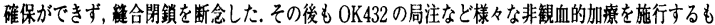

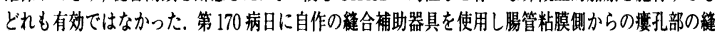
合を施行した，その後の経過は良好にて第 187 病日に退院となった，退院後8力月経過した現在， 捧孔の再発を認めていない．この治療法は，本症例のように長期に種々の保存的治療を行っても閉 鎖しない傕治性瘦孔に対して試みられてもよい治療方法のひとつであると考えられた。

PPS-3-198直腸癌術後の肝動注化学療法中にガス産生肝膿瑒を来し た 1 例 西澤袏史，水田 稔，吉田 修，池田英樹，山根正修，宇高徹総， 曽我部長德, 前田宏也, 白川和豊, 大屋 崇 (三豊総合病院外科)

大腸㿋肝転移に対する5-FU+CDDP の併用肝動注療法の有用性については, 多く報告されている が, 動注療法に伴う合併症も多くみられる。今回我々が経験した症例は, 直腸癌術後の肝動注化学療

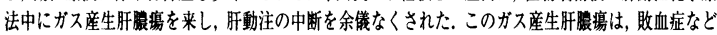
を合併し，遷延しやすく，予後不良といわれている。この症例では，抗生剤を投与するとともに，経

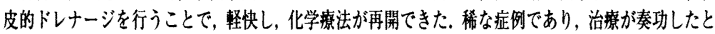
考えられたので, 報告する. (症例) 58 歳，男性. 進行直腸癌，多発肝転移の診断で, Hartmann's ope を施行した（組蟣学的病期：Rs, 2型， se, P0, ly3, v3, H2, M(-), nl (+), D2, ow (-), aw $(+)$, stage4, 根治度 C)術後，5-FU+CDDPによる肝動注化学㙩法を開始したが，4 ケ月後に発熱，

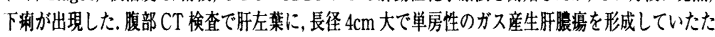
め，抗生郕 (CLDM と IMP) の投与を継続するとともに，CTガイド下に経皮的肝䭪瘍ドレナージ術 を施行した，徐々に症状は轻快し，肝動注化学療法を再開することができた，

PPS-3-199 FDG-PET により明瞭に描出された $\mathrm{sm} 2$ 大腸癌の 1 例

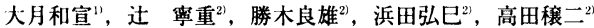

(日鎆記念病院 健診センター ", 日銅記念病院外科 ${ }^{2}$ )

【はじめに】 2002 年 3 月より大腸癌を含め 12 疾患について ${ }^{18} F D G-P E T$ 検査は保険適用 になった。これまで進行再発大腸癌症例の有効性は多数報告されているが, 早期大腸癌 の報告は少ない，今回明瞭に描出された $\mathrm{sm} 2$ 大腸癌の1例を経験したので報告する.

【症例】61 歳男性. 主訴, 腹部不快感. 現病歴, 腹部不快感にて 2002 年 12 月 16 日, FDG -PET 癌検診施行. 胃唄門領域および盲腸近傍に FDG の高濃度集積がみられた. 上部, 下部内視鏡検査で進行胃癌および早期大腸痻と診断し，2003 年 1 月 30 日胃全摘, 脾合 併切除および盲腸部分切除施行. 組織所見, 胃：U, 5 型, $10 \times 5.2 \mathrm{~cm}, \mathrm{~T} 3(\mathrm{SE}), \mathrm{N} 1$ H0, P0. M0, porl, ly3.v3.StageIIIA, 大腸：Isp, $1.5 \times 1.5 \mathrm{~cm}$, sm2, 垂直浸潤 $1820 \mu \mathrm{m}, \mathrm{H}$ 0, P0. wel, ly0.v0. 【考察】安田ら"は，59 例の大腸腺腫の検討では，14 例 $(24 \%)$ が描 出陽性で, $13 \mathrm{~mm}$ 以上の 10 例中 9 例 $(90 \%)$ が描出陽性と報告している. 本症例は Isp, 最大経 $15 \mathrm{~mm}, \mathrm{sm} 2$ 浸潤大腸癌が明瞭に描出されたことから，大腸において FDG-PET により描出された病変は悪性度を考虑した治療が必要と考えられた. 1) Yasuda Set al : ${ }^{18}$ FDG PET Detection of colonic adenomas. JNM42：989-992, 2001

PPS-3-200 FDG PET (positron emission tomography) が診断に有用 であった大腸痁腹膜再発の 2 症例

大北 完，小篠洋之，岡 洋右，的野敬子，志田誠一郎，石橋正哉， 笹富輝男, 荒木靖三, 緒方 裕, 白水和雄

(久留米大学外科)

今回 FDG PETにより大腸癌腹膜再発が確認された2例を経験したので報告する. (症例 1) 60 歳，女性. 1999 年 11 月に直腸癌 (Ra) se, nl, H0, P0, M ( - ) , StageIIIa の診断にて低位前 方切除術を施行した，その後肝転移を認め，肝切除術を施行した．同年 4 月には原発性肺癌に て右肺部分切除術を施行した，その後腫㑥マーカーの上昇を認め再発巣不明な為 FDG PET を施行したところ 4 力所の異常集皘像を認めた，手術を施行し，PETと一致する部位に腫倡を 認め摘出した，術後病理結果は adenocarcinoma だった（症例 2) 70 歳, 男性. 2001 年 4 月に 多発性大晹癌 se, nl, H1, Pl, M (-), StageIV の診断にて右半結腸切除術, 前方切除術を, 肝転移に対し肝部分切除術を行った，以後腫場マーカーの上昇を認め再発巢不明な為FDG PET を施行したところ 3 力所の異常集皘像を認め手術施行. 術中所見では腹腔内に無数の粟 䊉腹膜播種巣を認め手術不能だった（まとめ) 粗大結節型の腹膜再発に対してはPETによる 画像診断は有用であるが，粟粒小結節結節病柴のPET での描出は困難と考えられた。 
PPS-3-201 大腸瘦術前診断における FDG-PET の有用性 森 美樹, 水谷知央, 関野誠史郎, 松友寛和, 小久保光治, 佐治重豊 （木沢記念病院外科）

【目的】大腸癌術前診断における FDG-PET の有用性を検討した.【方法】術前にFDG-PET 検査を施行した大腸㢖手術例 14 例について, FDG-PET 所見，患者背景，踇床病期，標本 所見，病理診断，リンパ節転移，肝転移，CEA 值等とを検討した. 【結果】男女比は $10: 4$, 年龄は 44 90 歳. 全例で術前PET 検査で原発集にFDG の有意な集積を認めた. SUV 值は 4.9 17.9（平均 10.2）であった，集皘部位は，直腸 9 例，S 状結腸 3 例，横行結晹 2 例，直 渴 1例であり，注腸造影検查，大腸ファイバーで診断された原発巣とほほ一致していた．内人

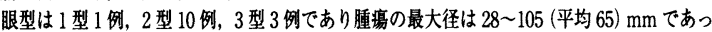
た. 䧗床病期は I期 2 例，II 期 1 例，IIIa 期 2 例，IIIb期 3 例，IV6 例であった. すべて腺 癌で，壁進達度は sm2 例， mp3 例， ss4 例， se2 例， si3 例であった. リンバ節転移晹性例は 3例であったが，うち 1 例で FDG 集積を認めた，肝転移陽性例は 5 例であったが，うち 3 例で FDGの肝人の集積を認めた. CEA 值は 14 例中 4 例が正常, 10 例が高值であった. そ れらのCEA 值と原発巣のSUV 值には明らかな相関関係は認めなかった。結語】大腸癌原 発巣への FDG-PETの sensitivityは 100\% であり術前診断に非常に有効であった.

PPS-3-202 下部直腸癌の術前リンパ節転移診断における MDCT の 有用性の検討

清松知充 ${ }^{11}$, 渡逶聡明 ${ }^{11}$, 南 学 ${ }^{21}$, 小室安宏"1, 釣田義一郎"”,

大友 邦2), 名川弘一1)

(東京大学大学院腫瘍外科学 ${ }^{11}$, 東京大学医学部付属病院放射線科 ${ }^{2}$ )

【目的】MDCT (multidetector row CT) を用い従来法よりも正確な下部直晹蜜の術前りンパ 節転移診断が可能であるかを検討した. (方法】対象は $\mathrm{Ra}, \mathrm{Rb}, \mathrm{Rbp}$ の T2〜 T4 の直腸癌 25 症例. MDCT を用い補助手段として経肛門的に air を注入した上で造影刻を使用して撮像し た. 短径長 $\geqq 8 \mathrm{~mm}$, 長径/短径 1.5 , リンパ節周囲の毛羽立ち，等を診断基龩に個々の症例を 術後の病理診断と対照させてリンパ節転における MDCT の正診事を求めた。成績]大晹症 取扱い規約に基いた N (-) N1 N2 の分類では over all accuracy は 80\% (20/25) であった. Dukes 分類に基づいた $\mathrm{N}(-) \mathrm{N}(+)$ の分類では over all accuracy $88 \%(22 / 25)$ sensitivity $86 \%$ (6/7) specificity $89 \%$ (16/18) と良好な成嘖を得た. 【考察】 MDCTを使用すること によりさまざまな角度から詳細にリンパ節転移を評価できるようになりその正診率は高い， さらにAir 注入を併用することでその局在部位を主要血管との位置関係において正確に把 握することが可能になりより正確なりンパ節転移の総合的な術前評価が可能であった。

PPS-3-203 結腸直腸癌治療における MDCT/PET の有用性の検討 岡部光規, 三浦 康, 溝井蜸幸, 石井誠一, 椎葉健一, 佐々木笺 (東北大学大学院生体調節外科学)

結渴直晹癌における Multidetector-row CT (MDCT) /PET の有用性を以下の点につい て検討した. (1) 結腸直腸癌リンパ節転移の術前診断：これまでは, CT, MRIにて描出 されるリンパ節と思われる構造物の大きさが手䑨かりであった.しかし、リンパ節のサイ ズと病理診断の結果が相関しないことは臨床上よく経験することである．特にサイスが 小さい場合, 従来の画像診断では転移があるのかないのか診断は困難である. 我々は最 近, 主病変に関しては感度・特異度ともに高いPETが, リンパ節転移診断においてはと の程度であるかを，進行大腸癌全症例に施行して検討している. 更に, PET だけでなく， MDCT による 3 次元画像と PET 画像を組み合わせることにより,リンパ節転移の有無 のみならず，正確な局在診断も同時に行い，その有用性を検討している. (2)化学療法の 効果判定：これまでは，CT，MRIにて描出される転移巣の大きさが判定基準であった 我々は, PETにて, FDG 取り込み率の変化を調べ, 化学療法の効果判定に有用であるか 否かを検討している.更に, MDCTによる3 次元画像と PET 画像を組み合わせることに より，どの部位の取り这みが変化しているのかを描出できるか検討を行っている.

PPS-3-204 大腸癌術前診断における所属リンパ節転移評価の意義 井出宗則, 山口 悟, 坪井香保里, 堤 荘一, 浅尾高行, 桑野博行 (群馬大学第 1 外科)

【目的】 FDG-PET が術前診断のなかでリンパ節転移を中心とする転移の評価 に有用であるかを検討した.【方法】CT, MRI, FDG-PET の術前のリンパ節転 移，遠隔転移の正診率を算出．病理診断用スライドで, リンパ節径と転移の有 無を比較した. FDG-PET のリンパ節転移検出能評価のため 15 症例で腫瘍に 接していない転移りンパ節内の腫瘍長径を計測. (結果】 CT のリンパ節転移に 対する特異度，感度，正診率は $95.4 \% ， 15.7 \% ， 64.9 \%$. MRI は $66.6 \%, 33.3 \%$, 48.4\%. FDG-PET は $58.3 \%, 15.3 \%, 36.0 \%$. CT で偽陽性症例の最大リンパ節 径平均は $9.5 \mathrm{~mm}$ で偽陰性症例では平均 $8.3 \mathrm{~mm}$ と有意差がなかった. 2,3 群転 移リンパ節径の平均は, 術前 $\mathrm{N}(-)$ 病理 $\mathrm{n}(-)$ 症例の最大リンパ節徍の平 均と有意差がなかった. FDG-PET 評価用に検討した転移リンパ節内の腫場径 は 4-18mmで，リンパ節転移が検出された症例は 1 例のみで腫瘍の長径は 4 $\mathrm{mm}$ であった.【結語】 CT, MRI では 9mm 以下のリンパ節転移の判定は困難 で, FDG-PET は術前のリンパ節転移の評価には必ずしも有用ではない
PPS-3-205早期大腸痖深達度診断における超音波内視鏡の有用性と 限界

谷田 孝"，牧野正人"，安宅正幸"，尾䗁 舞"，大井健太郎"，

中村誠一"1,，八島一夫" , 村脇義和 ${ }^{2}$, 貝原信明"

(鳥取大学第 1 外科" , 鳥取大学機能病態内科学 ${ }^{2}$ )

〈はじめに〉近年，早期大晹瘦，特に直晹㿋に対し，種々の低侵襲・樎小手術 が增加し，深達度診断はリンパ節転移の钼点から重要となっている.〈对象〉超 音波内視鏡を施行された大腸症症例 32 例を検討した.〈桔果〉全体の深達度正 診率は $66 \%$ ，(深読みが 8 例 $25 \%$ ，浅読みが 2 例 6\%)であった. 肉眼型では隆 起型 $58 \%(7 / 12$, 深読み 3 例，浅読み 2 例)，表面隆起型 $50 \%(4 / 8$, 深読み 4 例)，陥凹型 $86 \%$ (6/7, 深読み 1例) と陥凹型で正診事は高く，誤診例は深読 みが多かった，占居部位別，組織型別では差を認めなかった，深達度別では， $\mathrm{m}: 56.2 \%(9 / 16), \mathrm{sm}: 80 \%(8 / 10), \mathrm{mp}: 80 \%$ (4/5) と m 密の正診事が低 かった〈〈まとめ〉超音波内視鏡による大晹早期癌の深達度診断は肉眼型が隆 起型の場合，超音波の娍衰もあり正しく診断し得ない場合を念頭におき，注晹 透視，内視鏡を加えた総合的な深達度診断が重要であると考えられた。

PPS-3-206大晹癌手術症例のリスク評価

渡辺 蔵"，保田尚邦”，中島 修"”，高村光一"，北村雅也"，

後藤 学", 塚田一義", 角田明良 ${ }^{33}$, 草野満夫 ${ }^{31}$

（川崎幸病院外科"，伊势崎市民病院外科 ${ }^{21}$ ，昭和大学一般消化器外科 ${ }^{3}$ )

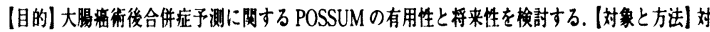

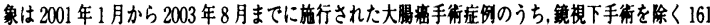

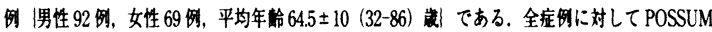

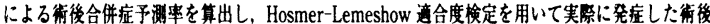
合併症数と比较した. 次に全症国の Physiological Score (PS) と Operative Severity Score (OSS)

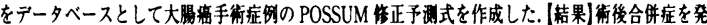
症したのは 161 例中 48 何 (29.8\%)であった. 術後死亡㾏例は認めなかった. Hosmer-Lemeshow

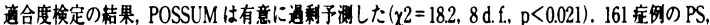
OSSを共変量としたロジスティック回㷌分析の落果, $\log [\mathrm{R} /(1-\mathrm{R})]=-4.49+(0.08 \times \mathrm{PS})+$

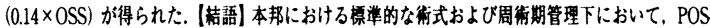

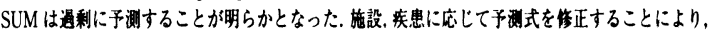
リスク判定指標としてPOSSUMがより有用なツールとなる可能性があると考えられた。

PPS-3-207 巨大直腸 GIST 切除 2 例の報告

森山 化", 川村統勇", 川村 武", 石原行雄", 河野洋一", 松田寿夫 ${ }^{1}$ ，池上雅博 ${ }^{2}$

(川村病院外科", 東京蕊患会医科大学病理 ${ }^{21}$ )

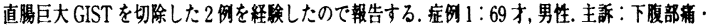
下血. 現症: 平成 15 年 5 月頃から時々腹有・下血を自覚し，情査目的で当院稆介受診. CF・㙏

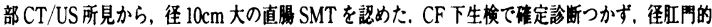

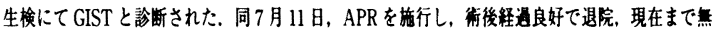

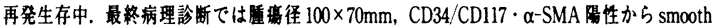
muscle type で mitosis 1/20HPF から low grade malignancy と診断された。症约 2:59才, 女性.

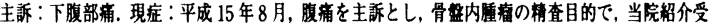
診. CF・EUS・腹部 CT/USにて径 $8 \mathrm{~cm}$ 大の SMT を認め, 経肛門的生検にて GIST と診断され

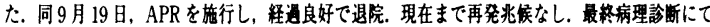
腫鹪径 $80 \times 70 \mathrm{~mm}, \mathrm{CD} 34 / \mathrm{CD} 117$ のみ淂性の uncommitted type で mitosis $0 / 20 \mathrm{HPF}$ も緗腹密度

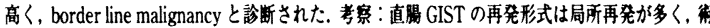
後 10 年以涟での再発例も報告されており，今後も十分なFollow upが必要と考えられる.

PPS-3-208 直腸 (Rb) GIST 術後閉鎖リンパ節再発に対してメシル酸 イマチニブが著効した 1 例

原田明生, 菅江 崇, 小林 雾, 岡村行泰, 高瀬恒信, 中山茂樹, 矢口豊久

(厚生連海南病院外科)

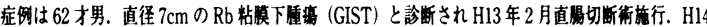

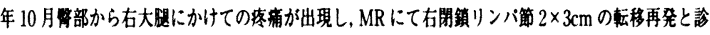

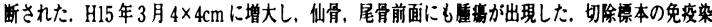

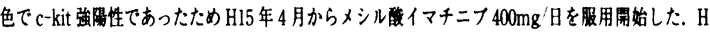

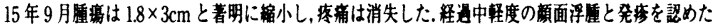
以外重篤な副作用はなく H16 年1月現在元気に就亲している。一般にGISTはリンバ節転移はまれ とされており，切除に庰しての垶清に゙ついて一定の見解はないか，今後さらに検討が必要である。

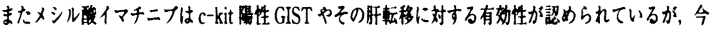

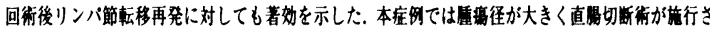

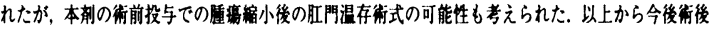
補助㙩法や術前投与なども含めた手術との組み合わせ治丵による新しい展開が期待される。 
PPS-3-209 直腸壁外性に有茎性発育した gastrointestinal stromal tumor, smooth muscle type $の 1$ 例

川口康夫"，杉野圭三”，小島康知"，西原雅浩"，矢野将觫”，

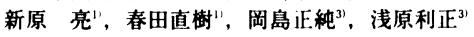

(あか杖会土谷棇合病院外科", 松山赤十字病院外科 ${ }^{21}$, 広島大学第 2 外科 ${ }^{3}$ )

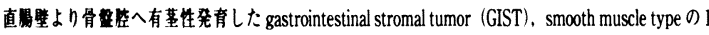

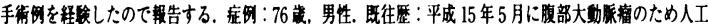

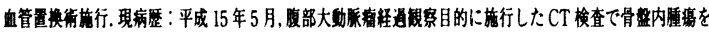

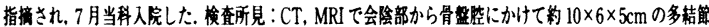

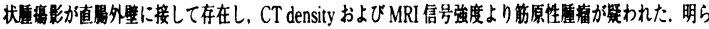

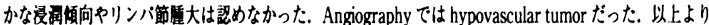

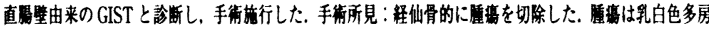

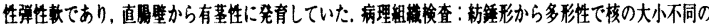

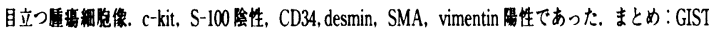

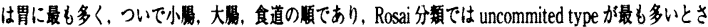

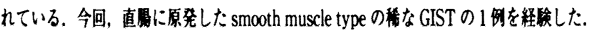

PPS-3-210 肛門周囲膿痀により無血小板症を伴う重症感染症に陥っ た一例

小山田尚, 村上雅彦, 矢野英史, 米山幸宏, 役塚规雄, 中野知之,

尾绮雄飛, 藏本純一。

(岩手県立大船渡病院外科)

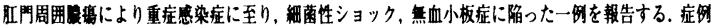

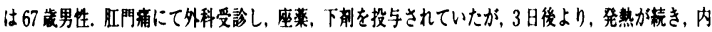

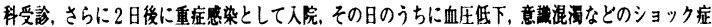

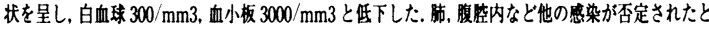

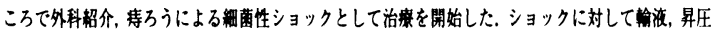

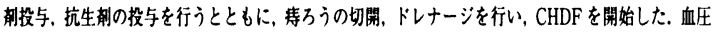

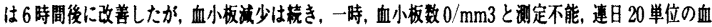

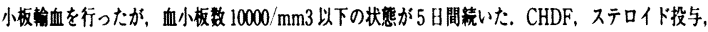

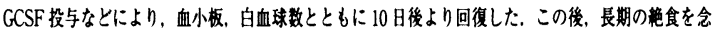

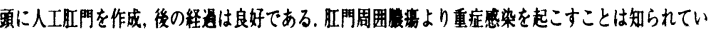
るが，時に見选されたり，对応の避れることがあり，常に念頡においておく必要がある。

PPS-3-211 異なる臨床経過を辿った肛門扁平上皮癌の 3 例と免疫組 織学的検討 栗原 媇”，岡島正純”，池田 聡"，川堀勝史"，有田道典"， 惠木浩之"，浅原利正"，倉岡和矢"，伊藤玲子"，安井 弥" (広島大学第 2 外科", 広島大学第 1 病理 ${ }^{2}$ )

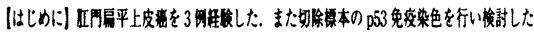

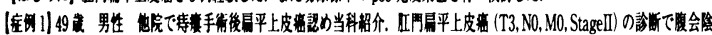

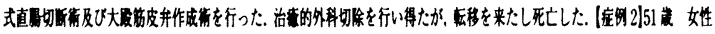

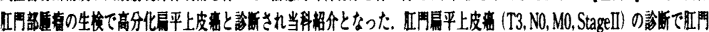

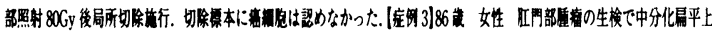

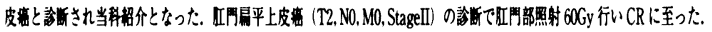

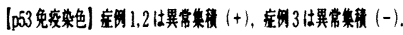

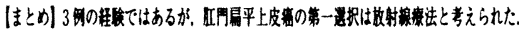

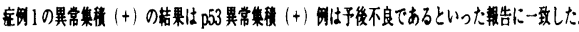

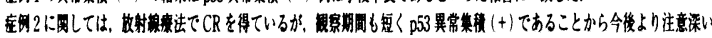
繁方必要であると思われた。

PPS-3-212 直腸肛門部悪性黒色腫に全身悪性リンパ腫が合併した一 例

草草也，松村博臣，大垣雅晴，宮田圭吾，井川 理，钣塚亮二，

藤井宏二, 下間正隆, 泉 浩, 竹中 温

（京都第二赤十字病院外科）

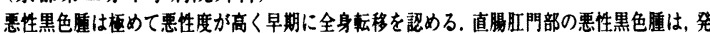

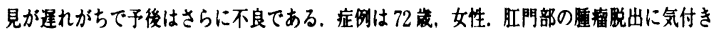
近医受診. 肛門部の隆起性病変にて当院稆介。直渴下部に長径 $4 \mathrm{~cm}$ の弾性硬の黑色隆起性病

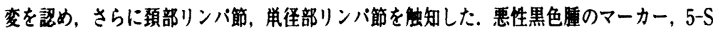

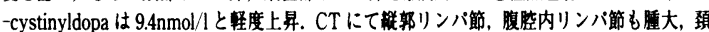

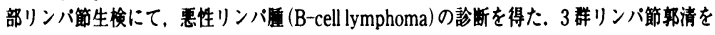

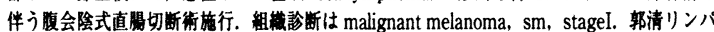

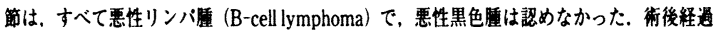

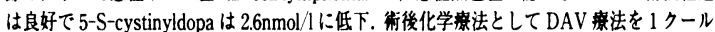

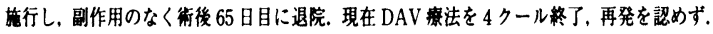

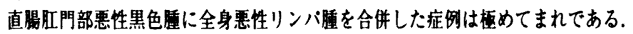

PPS-3-213 類例のない極めて稀有な肛門瘦の 1 例 野澤慶次郎, 松田圭二, 安達実樹, 白 京訓, 大見环磨, 矢後髟志, 荒井武和，味村俊樹，小平 進

(帝京大学外科)

肍門部の過䛇腫から腺癌の発生した極めて稀有な症例を経験したので報告する。症例は 60 才男性, 䄪 10 年前より肛門部に腫りを認めるも放置. 䄪 1 年間に徐々に腫大傾向に あり，近医受診. 約 $3 \mathrm{~cm}$ の腫堭は 5 時方向の菌状線直下の肛門僛に存在. 局所切除にて cyst hamartoma の診断であった. 6 ケ月後局所の硬結と左鼠径部リンパ節の腫脹を認 めたため, 当院紹介となり，肛門腫場切除生検および左鼠径リンパ節郭清を含めた切除

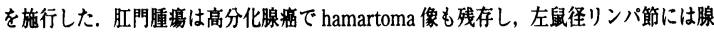
瘭の転移を認めたため根治手術目的に腹会陰式直腸切断術, 両側方郭清術施行。病理組 梌查にて Adenocarcinoma originating from hamartoma, remaining in the anal canal, well differentiated adenocarcinoma, depth al, ly0, vl, $\mathrm{n} 3(+)(9 / 108)$, ow $(-)$, aw $(-)$, ew (-)，と診断された．肛門できた過誤腫の中に腺癌混在していることと，局 所再発及び単径リンパ節転移を呈したことは非常に珍しい。通誤腫より発生したと思わ れる肛門部腺癌の報告は，検索した限りでは今まで報告はなく最初の報告例である.

PPS-3-214 外腸骨動静脈合併切除人工血管による同時再建により根 治術をなしえた大腸沿局所再発の一例

石橋生哉, 田山慶一郎, 笹富輝男, 志田誠一郎, 大北 亮, 荒木靖三, 緒方 裕, 青柳成明, 白水和雄

(久留米大学外科)

現病歴：症例は 72 嵅，女性。平成 11 年に他院にて直腸䑩にたいし回盲部切除術を施行されたが，

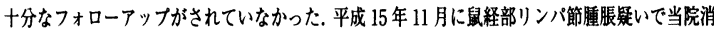
化器病センターへ紹介された，現症：右下腹部に $4 \mathrm{~cm}$ 大の腫痹を認め，弾性硬，可動性不良．経

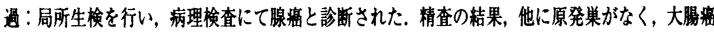

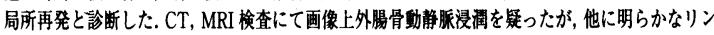

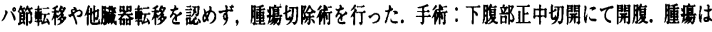

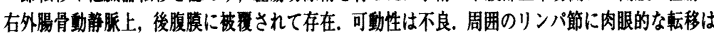

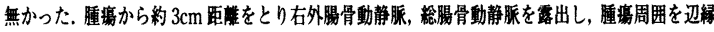

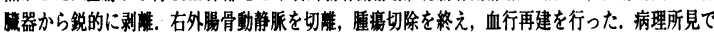

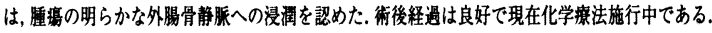

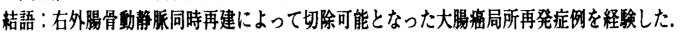

PPS-3-215 腹部大動脈㿔と同時手術を施行した上行結腸癌の一例 友國 晃"，仲原正明", 上島成幸", 赤松大樹", 今分 茂",

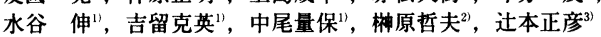
(大阪警察病院外科 ${ }^{1}$, 大阪警察病院心堿血管外科 ${ }^{2}$, 大阪警察病院病理科 ${ }^{3)}$ ) 消化器外科において他科領域の疾患との同時手術かしばしば行われる. 今回上行結腸福と

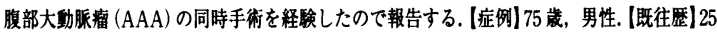

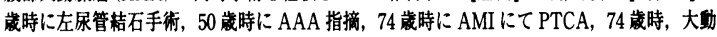

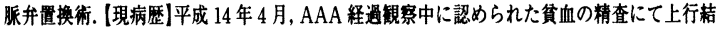

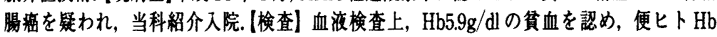
(++). 腄鹪マーカーはCEA 3.9ng/ml で正常, CA19-9 99U/ml で高值であった. US, CT にて上行結晹の $7 \mathrm{~cm}$ 大の腫痽と最大往 $66 \mathrm{~mm}$ の AAA を認めた. 㐿術平成 14 年 5 月, 左 腹部斜切開による後腹獏アプローチでの AAA クラフト置换に繶いて, 腹部正中切開にて

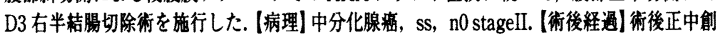
感染を認めたが経通良好で, 術後 1 年 5 ケ月現在, 再発なし. [考察]開腹創を別にすること, 後腹膜の手術創を連続させないこと, 人工血管を痛壁でラッピンクし露出させないことな

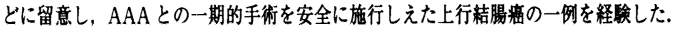

PPS-3-216 大腸癌に同時性に原発性・転移性卵巣腫瘍を合併した 5 症例の検討

山下秀樹，劉 中諴，松本佳博，太田勇司，足立 晃

(田川市立病院外科)

当院において 1980 年 1 月から 2003 年 12 月までの期間に, 大晹癌と同時性に原発性卵

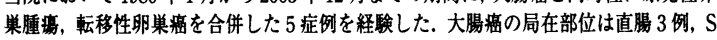

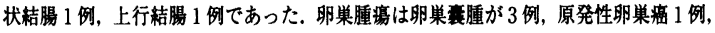

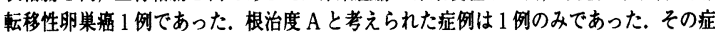
例は 65 歳で, 大腸内梘鏡検査にて歯状線より S 状結腸に連続する全周性の絾毛状の小 結節集簇病変と腹部 CT 検查にて $15 \mathrm{~cm}$ 大の卵巣衰腫が認められた。術前に血液生化 学検査にて $\mathrm{Na} 117 \mathrm{mEq} / \mathrm{l}, \mathrm{K} 2.1 \mathrm{mEq} / \mathrm{l}, \mathrm{Cl} 60 \mathrm{mEq} / \mathrm{l}$ と著明な低下を認め, いわゆる electrolyte depletion syndrome (EDS) を呈した症例であった. 腹会陰式直晹切断術,

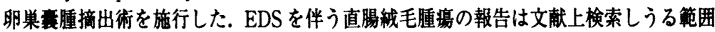

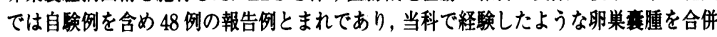
した報告例は娭索し得た中では報告例がなく，非常にまれな症例であると考えられた。 大腸癌に合併した卯巣腫場の症例について，若干の文献的考察を加えて報告する。 
PPS-3-217 卵巣㿋術後大腸転移の 1 切除例

芝原一繁"，遠藤直樹"，天谷 奖"，黑川 勝"，八木真悟"，

魚津幸藏"，長谷川洋"

(富山赤十字病院外科"1, 富山赤十字病院病理科 ${ }^{21}$ )

症例は 60 歳, 女性. 主訴は腹痛. 平成 6 年に卯巣疾に対して単純子宮全摘, 両湖付属器切除, 傍大動脈りンバ節, 骨整内リンハ節郭清, 大網切除手術を施行され，その後化学察法を施行さ れている。婦人科外来経過観察中, 平成 15 年 6 月, 腹痛力゙出現し，腹部 CTにて上行稆腸の 壁肥厚を認めた，大晹内梘镜検查にて同部位に全周性の狭窄を認めた，大晹癌を知い入院と なった，身体所見に異常はなく，血液生化学的所見ではCA125が上昇していた，腹部造影 CT 検查で，上行結晹壁の全周性肥厚を認め，周囲りンパ節の腫大を認めた。腹水，胿転移は認め なかった，大腸内視镜検查にて癌細胞は証明されなかったものの，上行結腸癌を筑い，手術を

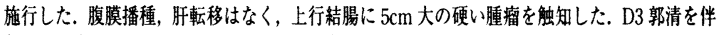

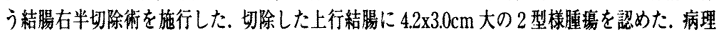

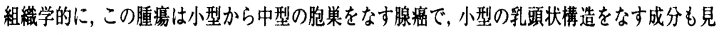
られ，免疫組織学的に卵坚原発の転移性の紫液性乳頭状腺症と診断された。術後経通は良好 で, CA125は正常化した，現在明らかな再発兆候はなく，化学撩法を施行中である。

PPS-3-218 大腸癌術後 10 年目に脾転移をきたした 1 例 山口智弘",, 山下哲郎", 小出一真", 谷口史洋", 塩飽保博", 濱島高志"，池田栄人"，武藤文隆"，栗岡英明"，細川洋平"21 (京都第一赤十字病院外科", 京都第一赤十字病院検査部病理 ${ }^{2}$ )

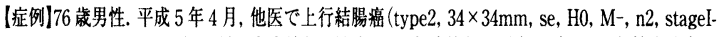
IIb, wel $>$ mod, ly1, v2) に対し右半結腸切除術, D3 郭清施行. 平成 15 年 10 月気管支喘息に て近医フォロー中, CEA91.9 と上昇し，腹部超音波にて脾滕に直径 $10 \mathrm{~cm}$ の high echo と low

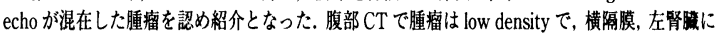

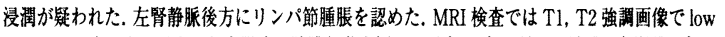

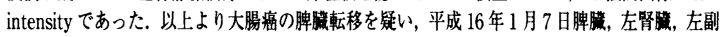

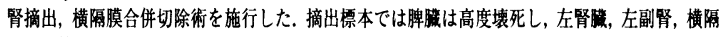

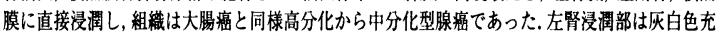

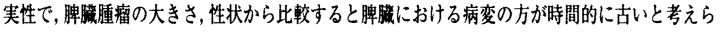

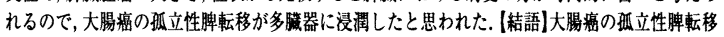
は非常に稀で, 術後 10 年目に再発した症列は報告がない，大腸船術後でも長期にフォローが必 要で，CEAの上昇をきたした場合は脾斩転移も考虑にいれるべきと考えられた。

PPS-3-219 大腸㿋脾転移の 2 切除例

渡辺裕策, 為佐卓夫, 森 尚秀, 山本 滋, 丹黒 章, 岡 正朗 (山口大学大学院消化器 ·腫鈞外科)

(症例 1) 71 歳男性. 平成 10 年 11 月 30 日盲腸㾂に回盲部切除を施行した. (高分化腺癌, ss, $\mathrm{nl}(+)$, stage3a) 平成 13 年 8 月 8 日腹部腫痛摘出術を施行した. 主腄場のほか多数の腹膜 播種を㥖め出来る限り切除し, 高分化型腺癌であった。術後 5 ' DFUR+CPT-11 を行い，その 後 5’ DFUR 内服で follow していた，平成 15 年 8 月 CEA の再上昇を契機に脾転移を診断し， 同年 12 月 17 日脾摘術, 右鼠径リンバ節摘出術を施行した。一部低分化な中分化型腺症であっ た. 現在外来にて全身化学寮法を施行中である。

(症例 2) 77 藏男性. 平成 15 年 5 月盲腸密肝脾転移を診断された。高龄のため二期的手術を子 定し, 同年 7 月 30 日, 回盲部切除を施行した（中分化型腺癌で si, p2, H1, M(+), $\mathrm{nl}(+)$, stage4)その後転移巣の增加がなかった為，10月6日肝部分切除と脾摘術を行い，術中 2 個の 播種性病変を認め切除した，中分化型腺癌であった．現在再発を認めず外来通院中である. (䊅語) 自駼例は服膜播種を伴い本来なら手術道応はない。しかし画像上㧓立性のため, また 転移单の增大が軽微なため手術適応と考えた。転移経路としては播種の可能性を否定できな かった. 術後杖全身化学㙩法の必要があると考えられた。

PPS-3-220 当院において経験した, 消化管転移乳癌 2 症例の検討 坂本明子", 三宅 洋",, 小沼憲祥", 益子貴行", 榎本克久",

朴 英智"), 根津 健", 天野定雄 ${ }^{2}$

(春日部市立病院外科"1, 日本大学第 1 外科 ${ }^{2)}$ )

消化管軽移乳癌は剖検例でも約 $8.9 \%$ といわれ，極めて稀である。我々の経験した 2 症例を，

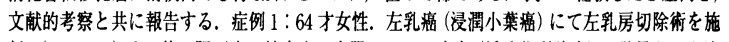
行. (Stage3A) その後, 胆石症の精查中, 大腸に type2 病変 (低分化型腺害) が発見さ九開腹 術施行. 病理所見にて, 乳癌の横行結腸小腸転移が認められた, 症例 $2: 78$ 才女性. 右乳癌に

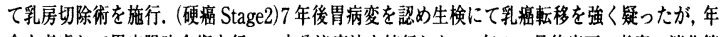
令を考慮して胃空腸吻合術を行い，内分泌滰法を続行した. 2 年 8 个月後癌死. 考察：消化管

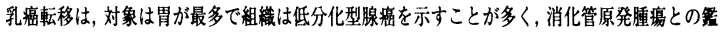
別は困難といわれる. 問題となるのは治寮法であり, 孚福転移の場合, 切除術後の予後が半年 以内とする不良報告例が多い一方, 化学内分泌潦法のみが著勃したとする報告も散見され，そ の生命予後の差は大きい, 自駼例 2 においても再発後, 内分泌㙩法のみにて 2 年 8 个月の長期 生存が得られた、今後, 乳癌患者数, 長期生存例の増加に伴い，消化管転移の類度も增えるこ とが予想される，乳癌消化管転移の可能性を再詔識すべきものと思われた。
PPS-3-221 同時性小腸転移を認めた大腸癌の 1 症例 徳本憲昭"，池出 聡”，石崎康代"，栗原 媇"，藤森正彦"， 惠木浩之", 有田道典"，岡島正純"，浅原利正"，有広光司 ${ }^{2}$ (広島大学第 2 外科", 広島大学病理部 ${ }^{2}$ )

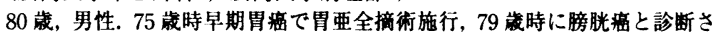
れ，放射線 +化学撩法を継続中であった. 80 歳時, 腹有を主訴に大腸内視鏡 検查を行い上行結腸に全周性の 2 型腫湯を認めた. 生梌結果は中分化型腺 癌であった. 回盲部切除術を行ったところ, 術中検索で回腸末端に腫葆性病 変を認め合併切除した。 上行結晹腫场は well diff. adenocarcinoma ss n (一), 小腸腫場は粘膜下層を中心に增殖し moderately diff. adenocarcinoma の像を呈していた. b-catenin, p53, CK7, CK20 のいずれの免疫染色におい

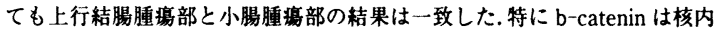
異常集皘を認め, 大晹癌の同時性小腸転移と思われた。 [考察]大腸癌症例に おいて，小腸転移の可能性も含め術中の入念な腹腔内検索の必要性を再確 認した．またb-catenin，p53，CK7 及びCK20の免度染色はH.E. 染色と併 用することにより，原発巣同定の補助診断として有用であると思われた．

PPS-3-222 直腸癌術後に腹直筋転移を来たした 1 例 兒玉英萧, 今村幹雄, 菊地 秀

(国立仙台病院外科)

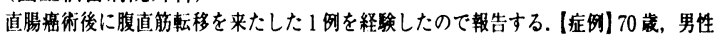

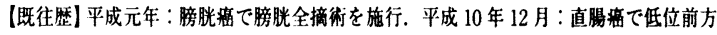
切除術を施行. (Rb, 3.0x2.5cm, mod, al, lyl, vl, nl [\#251 (5/8)], ow (-), aw $(-)$, stage IIIA, curA) (現病歴)術後 2 年間は, 内服化学㩧法を施行. その後, 再発 徵侯を認めず，経過稓察となっていた．平成 15 年 8 月（術後 4 年 8 ケ月）になり，右

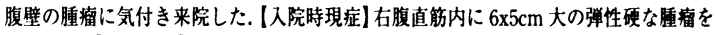
触知した. [画像所見]腹部CT で右腹直肪内に淡く造影される腫瘖を認めた。他に，遠

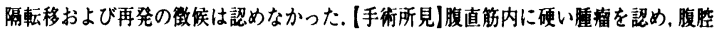

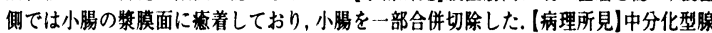

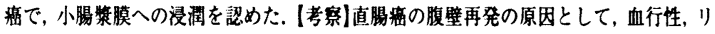
ンバ行性，播種性，直接浸榬などがある. 本症例では，腹壁再発の部位が手術創および ドレーンの挿人部とは崔れており，血行性転移の可能性があると考えられた，腹直筋へ の血行性転移の類度は非常に稀であり, 文献的考察を加えて報告する。

PPS-3-223 転移性腈楼を合併した大晹・小晹重複癌

宮澤基樹，淿藤克也，奥 喜全，谷 真至，冨永敏治，山上裕機 (和歌山県立医科大学第 2 外科)

【症例】 54 歳，女性. 検診にて筫血と便潜血倩性を指摘され，近医での注腸および下

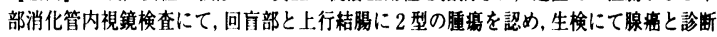

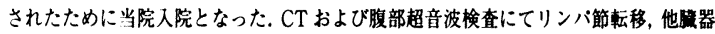

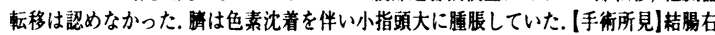

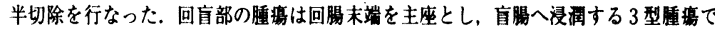

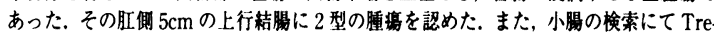
itz䩗带より $55 \mathrm{~cm}$ と $140 \mathrm{~cm}$ に狭得を認めたため，小晹部分切除を追加した、いずれも

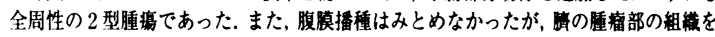

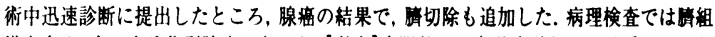
織を含め, 全て高分化型腺輹であった. [考察]肉眼的には多発病巣として矛盾しないと

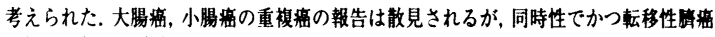

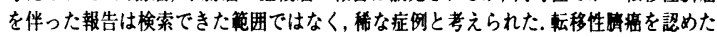
症例は非常に予後の不良であることが多いが，現在再発なく，6か月経週している。

PPS-3-224 Sister Marry Joseph's nodule $の 1$ 例 鶴田雅士"，長谷川博俊"，西堀英樹"，石井良幸"，似鳥修弘"， 岡林㓮史"，浅原史卓"，向井万起男"，北島政樹"

(慶應義熟大学外科", 慶應義熟大学病理"')

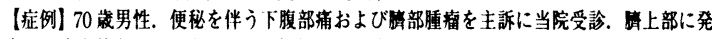

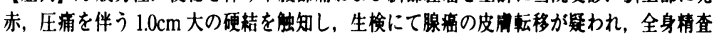

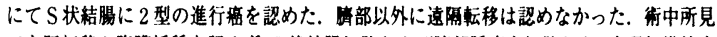

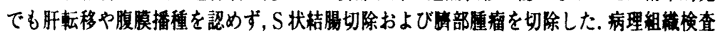

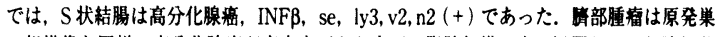

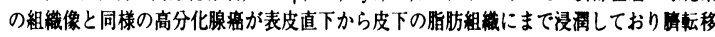
と診断した。術後補助化学澋法としてテガフール $400 \mathrm{mg} /$ 日を内服中である。街後 6 个月

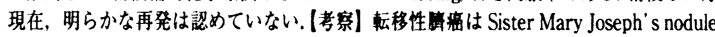

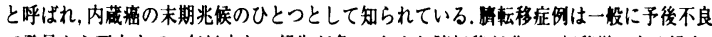
で発見から死亡まで 1 年以内との報告が多い.しかし输移が唯一の転移巣である場合，

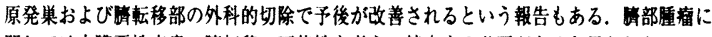

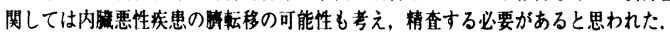




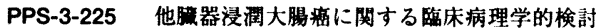
藤井 真, 根津理一郎, 藤川正博, 前田生平, 甲斐康之, 仲至永, 森島宏隆，武本智澍，山上裕子，吉川 澄 (大阪労災病院外科)

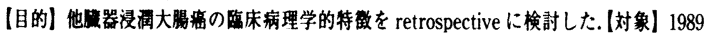

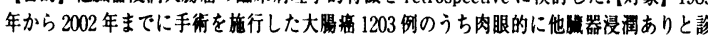

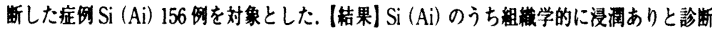

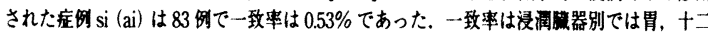

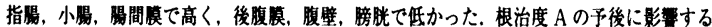

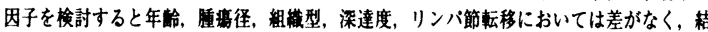

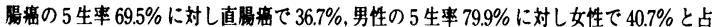

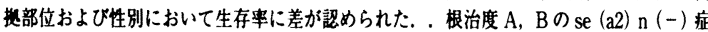
国において Si (Ai) と SE (A2) とを比較すると5生事はSE (A2) の81.2\%に対しSi (Ai) は $65.2 \%$ と有意に予後不良であった（まとめ漫洞器器によっては肉眼的所見と組椯

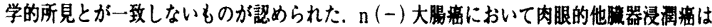

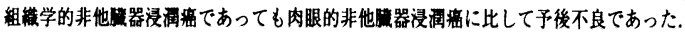

PPS-3-226 膡頭十二指腸切除術を施行した大晹癌症例の筷床病理学 的検討

松清 大，炭山嘉伸，柁原宏久，中村光彦，渡㟟 学，田中英則， 浅井浩司，榎本俊行，大沢晃弘，金井亮太

(東邦大学第 3 外科)

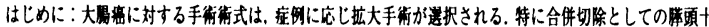

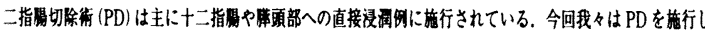

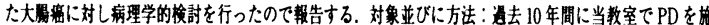

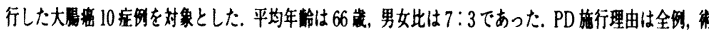

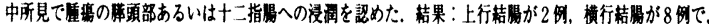

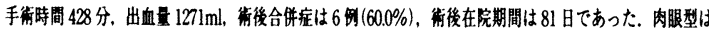

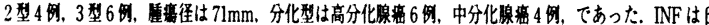

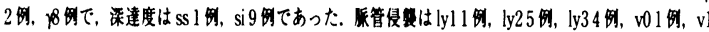

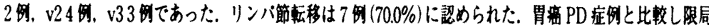

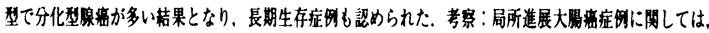

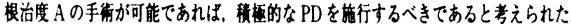

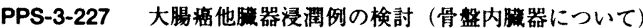
須藤阙, 池田栄一, 武田真一, 佐藤敏彦, 飯澤 (山形県立中央病院外科)

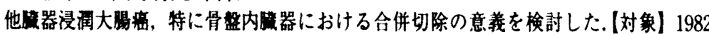

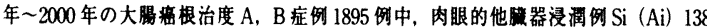

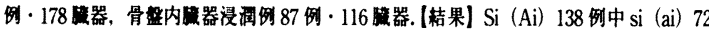

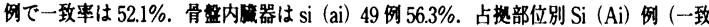

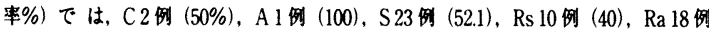
(38.8), $\mathrm{Rb} 34$ 倜 (70.6) 。器别 $\mathrm{Si}(\mathrm{Ai})$ 例 (一致事) は膀腃 39 例 (41.0)，前立腺 15

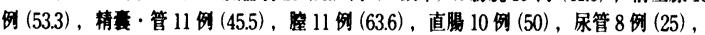

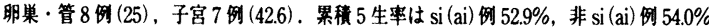
で当科の Stage3b 例 $48.9 \%$ と同等であった。膀胼切除症例の式例別一致率は部分切除 術 28 湖 $(42.8 \%)$ ，全接術 2 例 (0\%)，TPE 9 例 $(44.4 \%)$. si (ai) 例と非 si (ai) 例の 累皘 5 生事は $70.6 \%$ と $55.8 \%$, TPE・全接術と部分切除術は $71.6 \%$ と $58.7 \%$. 局所再発

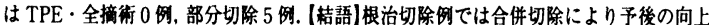
が期待できると思われるが，桡能温存に留意し，術式を検討すべきと思われた。

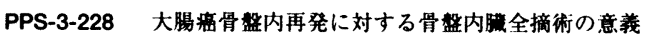
小出史彦，金井道夫，中村従之，大場泰洋，演口 桂，山口竜三， 古田美保, 井原 努, 渡辺芳雄, 矢野 孝 (春日井市民病院外科)

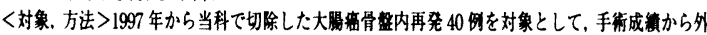

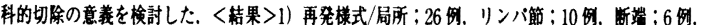

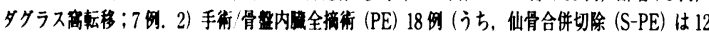

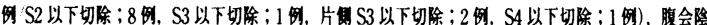

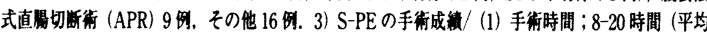

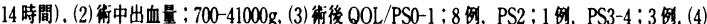

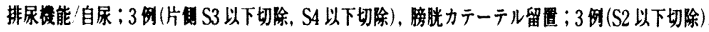

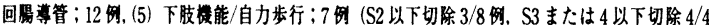

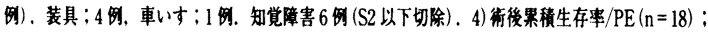

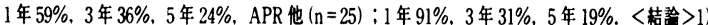

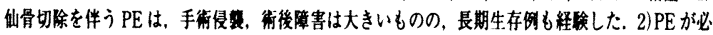

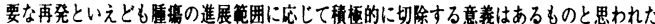

PPS-3-229 直腸癌術後局所再発における手術適応の臨床病理学的検 索 東 幸宏, 中村利夫, 浅井陽介, 林 忠毅, 宇野彰晋, 深澤貴子, 丸山敬二, 今野弘之, 中村 達

(浜松医科大学第 2 外科)

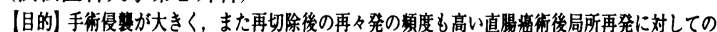

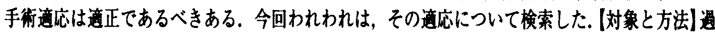

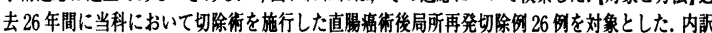
は，男性 13 约，女性 13 例，平均年秢は，60.5藏であった，上記につき，初回切除標本の惧床病 理学的特制と生存期間との此㜞检討を単変量解析にて行った。検定にはLogrank test を用いた。 【桔果】再切除後の予後を规定する因子として最も有用と考えられたのは初回切除標本の䐆管侵

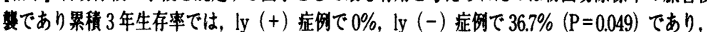

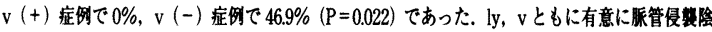

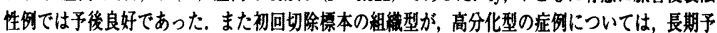

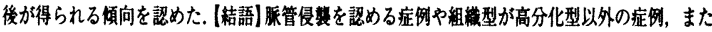
は治莺切除の期待できない症例については，手術以外の治僚を考虑すべきと考えられた。

PPS-3-230 直腸癌局所再発無再発生存例の検討

藤江裕二郎"，関本貢嗣"，大植雅之"，池永雅一"2), 福永浩紀"，

池田正孝"，山本浩文"，門田守人

(大阪大学大学院病態制御外科")，国立大阪病院外科 $\left.{ }^{21}\right)$

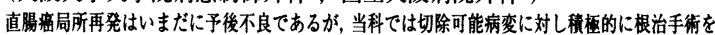
行ってきた， 1998 年 2 月加 2002 年 2 月までに当科を受診した道腸癌局所再発患者 36 名中 16

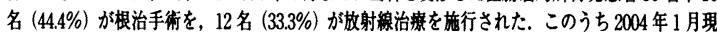

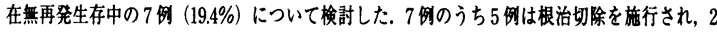

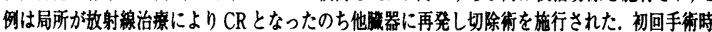

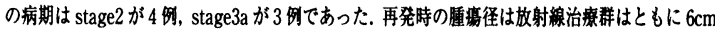

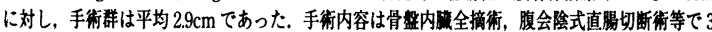

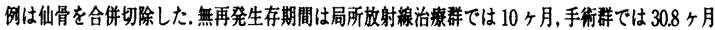

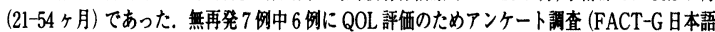

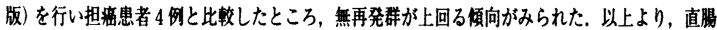

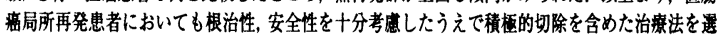
抧することで，患者のQOLを保ちながら無再発生存例を得られることが示唆された。

PPS-3-231 直腸癌骨盤内再発についての臨床病理学的検討 関 洋介, 福永浩紀, 瀬下 籍, 高山 治, 安井昌義, 池田正孝, 山本浩文, 大植雅之, 関本貢嗣, 門田守人

(大阪大学大学院病態制御外科)

【目的】直腸㿋骨盤内再発は, 肝・肺転移と並ぶ重要な問題である. 直腸 癌骨整内再発症例について, 臨床病理学的特徽を検討した.【対象】当科に て初回手術を行い，経過観察中に骨盤内再発と診断された 17 例および直 腸癌再発疑いにて紹介され, 直腸癌骨盤内再発と訩断された 28 例の計 45 例.【結果】1. 再発診断時に $81 \%$ の症例が疼痡・違和感など何らかの自覚 症状を示していた. 2. 再発診断時に $73 \%$ の症例がCEA 高值を示してい た. 3. 腫疸径は $69 \%$ の症例が $3 \mathrm{~cm}$ 以上であった. 4. 局所再発例は非局所 再発例と比較して, Rb-Rpの症例が有意に多かった. $5.78 \%$ の症例が初 回手術後 3 年以内に再発していた. 6. 術中腸管損傷, 断端陽性など, 手術 操作に問題があった可能性のある症例が全体の $40 \%$ に認められた. Iま とめ】直腸癌術後骨盤内再発例にみられる特徴を熟知し, 特に手術操作に 問題があった症例については，磁重な経過観察が必要と考えられた。

PPS-1-194 閉塞性左側大腸癌に対する 1 期的切除吻合術における術 中腸洗浄の有效性

岡田真樹，虽江久永，小島正幸，紫藤和久，冨樦一智，鯉沼広治， 佐藤知行, 永井秀雄

(自治医科大学消化器 - 一般外科)

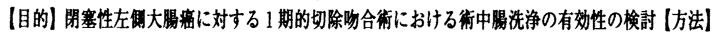

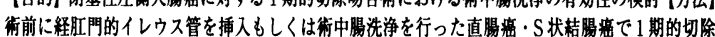

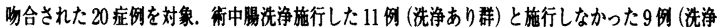

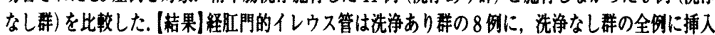
されていた，洗浄あり群の 2 例仗聚急手術，残り9例と洗净なし群 9 例はすべて待期手術であっ た. 手赫時間は洗净あり群 $247 \pm 58$ 分, 洗净なし $260 \pm 85$ 分であった $(\mathrm{p}=0.73)$. covering stoma

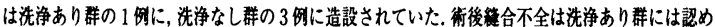

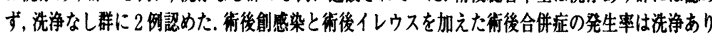

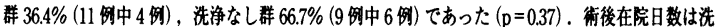

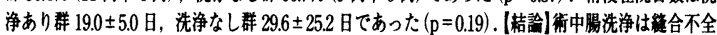
なとの術後合併症発生を少なくし街後在院日数も每編できる有効な方法である。 
PPS-3-232 当科における直腸疾局所再発に対する集学的治療の現状 向川智英, 藤井久男, 小山文一, 西沼 亮, 児島 裑, 勝井練太, 内本和晃, 武内 拓, 中島祥介

(奈良県立医科大学第 1 外科)

直腸癌では肝・肺への血行性転移とともに, 再切除の難しい局所再発が見られ, 一層治空 切除率を低下させ予後を悪くしている.今回われわれは直腸瘦局所再発に対する治㫫方針 とその成績を明らかにするため検討を行った. 対象は 1996 年から 2002 年の 7 年間におけ る $\mathrm{M}$ 癌を除いた直晹癌 CurA，B手術症例 146 例中局所再発をきたした 16 例（11\%）を 対象とした. 16 例中 6 例 $(37.5 \%)$ が局所以外の遠隔転移を併発しており，全身的なコン トロールを要した，局所再発に対する治療としては，外科的切除，全身化学㙩法，放射綿

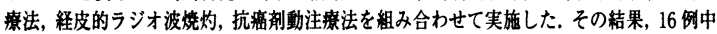
14 例 (87.5\%) は一度はPR となっており，PDは2 例のみであった。それでも現時点で直 晹害局所再発には外科的切除か最も効果の期待し，手術を積極的に行っている. しかし治 蒙切除するためには過大な手術が必要となる事も多く,QOL の低下を招く事もある.非治

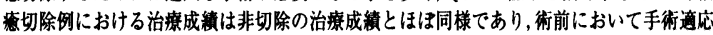
をいかに榽に決定し，非治蒙切除にならないように工夫するかが重要である。

PPS-3-233 進行直腸癌術後局所再発症例の集学的治療 吉谷新一郎, 黒田雅利, 田中弓子, 原田英也, 上野桂一, 斎藤人志, 小坂健夫，高島茂樹

(金沢医科大学一般消化器外科)

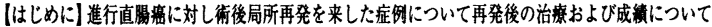

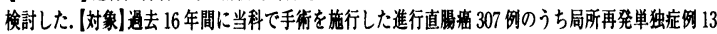

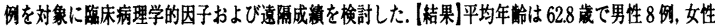

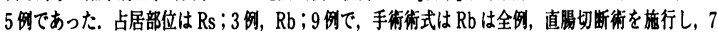

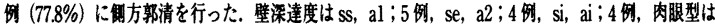

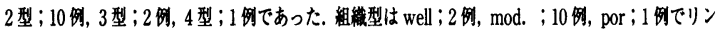

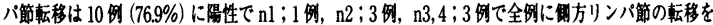
みとめた，局所再発の診断までの期間は 3 力月から 70 力月，平均 23 力月で䛦断後の治廉法として

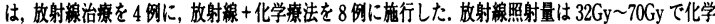

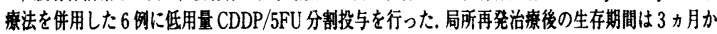

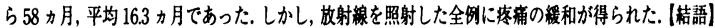
局所再発に对する集学的治缶は，QOLの改善から意義があると思かれた。

PPS-3-234 局所再発直腸癌への放射線化学寮法の有効性と治痖切除 症例の予後因子についての検討

宮本英典, 高橋慶一, 山口達郎, 松本 寛, 森 武生, 荒井邦佳, 岩崎善媇, 片柳 創

(東京都立駒込病院外科)

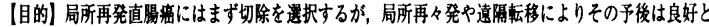

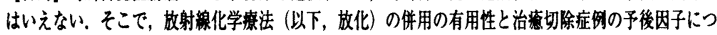

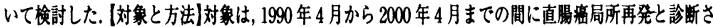

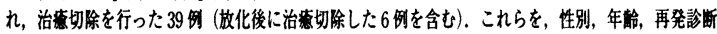

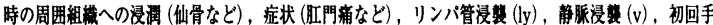

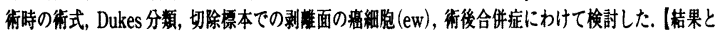

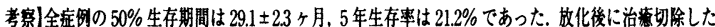
症匆の $50 \%$ 生存期間は $24.2 \pm 6.1$ ケ月, 5 年生存事は $16.7 \%$ であった。单变量解析では, 初回手術時の

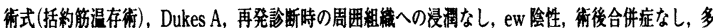

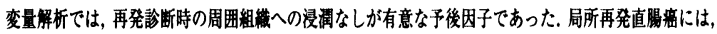

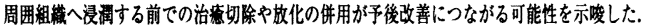

PPS-3-235 直晹癌術後の局所再発巣に対し経皮的 RFA 及び放射線 療法にてコントロールできた 1 例

志田誠一郎, 笹富輝男, 内田信治, 北里雄平, 石橋生哉, 荒木靖三, 緒方 裕, 白水和雄

(久留米大学外科)

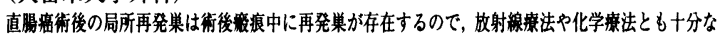

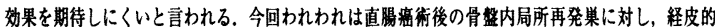

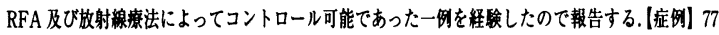

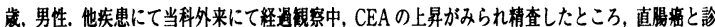
断され 2002 年 8 月低位前方切除街を行ったその後CEA 恃低下していたか，同年 12 月以降助合部

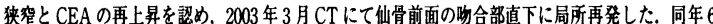
月CTガイト下に経皮的に穿刺してRFAを施行した。の後CEA は低下したが正常值までは下が りきらず，腫堭の残存を考え，同年 8 月から仙骨部に合計 $50 G \mathrm{y}$ の放射線察法を行った。その後 CEA

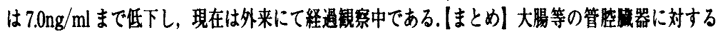
RFAは一般にあまり施行されていないが，今回は再発巣が明原でありCTにて比數的容易に診断

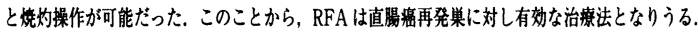

PPS-3-236 放射線撩法を施行した直晹盘術後骨船内再発症例の検討 畐永饭治，激藤克也，有井一雄，横山省三，松田健司，東口 崇, 奥 喜全, 山上裕機 （和歌山県立医科大学第 2 外科）

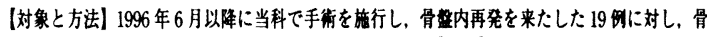

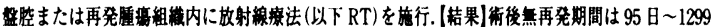

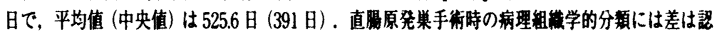
めず，病期分類では StageI，II，IIIa，IIIb，IVでそれぞれ717日，453.1日，3103日，403.5

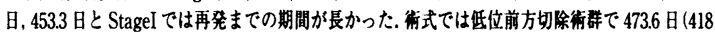
日）に对し，腹会除部直閧切断衙群で422.6日（315日）と再発までの期間が短い媔向があった。

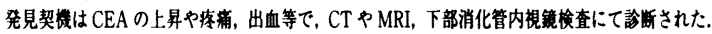

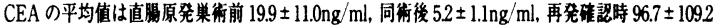

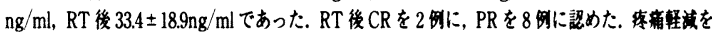

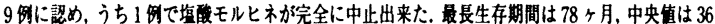

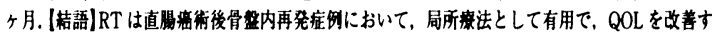
る. また，生存事の向上にも奇与する可能性があり，症例により根治し期待できる。

PPS-3-237 直腸瘭術後局所再発に対するラジオ波烧灼撩法(RFA)の 検討

藤山敏行，太田徹哉，渡辺啓太郎，佃 和憲，村上和正，内藤 稳, 清水信義

(岡山大学大学院腫鸤 $\cdot$ 胸部外科学)

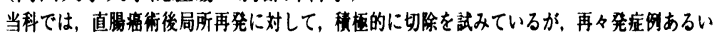
は手術不能の 3 例に対してRFA を行った。方法: 局所麻醉下にCOol-tip 哩, クラスターニー

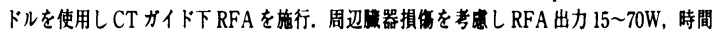

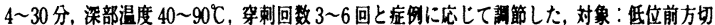
除街後局所再発に对し，Miles op. によ万再切除を行った後に局所再再発をきたした 2 的と

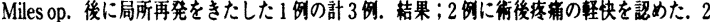

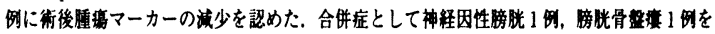

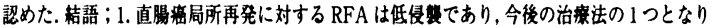

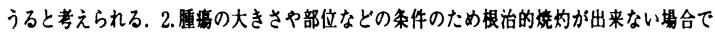

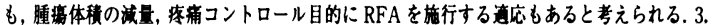

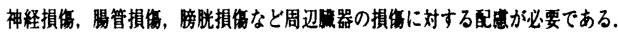

PPS-3-238 直晹㿋局所再発に対して tissue expanderによる骨艋底 形成後, 放射線化学撩法を行った一例

田中晃司"，村田幸平"，能浦真吾"，象山雅男"，石川 治"， 佐々木洋"，大東弘明"，土畦枯一郎"，宮代 埋”，今岡真義" (大阪府立成人病センター消化器外科"，ベルランド総合病院外科 ${ }^{2}$ )

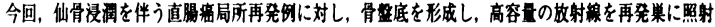

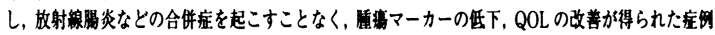

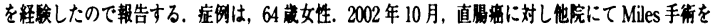

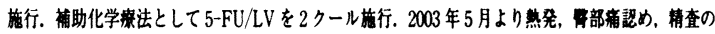

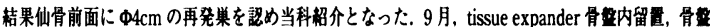
底形成術を施行. 10 月より CRTを開始(CPT-11 100mg/body dayl, 15,5'-DFUR 800mg/body day

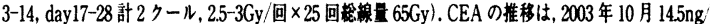

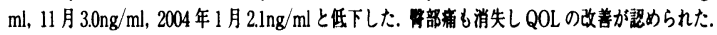

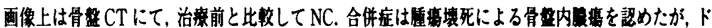

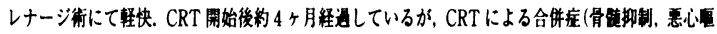

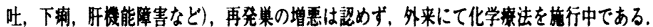

PPS-3-239 Gd 標識モノクローナル抗体 A7 を用いた大渴瘦局所再 発巣に対する MRI 造影郕の基碳的研究

栗生宜明，大辻英吾，市川大輔，岡本和真，稀原明於，山岸久一 (京都府立医科大学消化器外科)

【目的】大晹癌とりわけ直腸窝は局所再発が多く，予後不良である．面像診

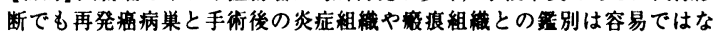
い.そこでヒト大腸癌と特異的に反応するモノクローナル抗体 A7 を Gd イオンで標識し, 局所再発巣の早期診断のための新しいMRI 造影郕として 応用可能かどうかを基碳的に検討を行なった。方法】(1) 抗体の Gd 標識： モノクローナル抗体 A7を Isothiocyanobenzyl EDTA を用いて Gd 標瑥 A 7 を作製した. (2) Gd 標識 A7 をヒト血清中で incubate し，血清中での安定 性を検討した. (3) Gd 標識 A7 の体内分布大晹峦移植ヌードマウスに Gd 標識 A7を静注し，経時的に腫离や正常組織中の集皘量を\% $\mathrm{ID} / \mathrm{g}$ で表した 【結果】Gd 標識 A7 の血清中での安定性は保持されていた. Gd 標識 A7は腄

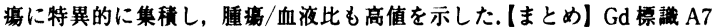
は直腸䍃再発診断のための MRI 造影郕に有用であると考えられた。 
PPS-3-240 直腸脱治撩の臨床学的検款

明神崇仁, 黒川良望, 貝羽義浩, 井上幸, 安凨実, 一瓶義博,

海野留司，里見 進

(東北大学大学院先進外科学)

直腸脱の治瘖法に関して,大別すると到達法として経腹的アフロローチと会陰アプロー 千に，また处瞉法として切除術と固定術，その他に分けられる。手術法の選択をめぐっ ては、経腹的アフロロー千の低再発事と会㓌アフフロー千の低侵撉性を検討することが典

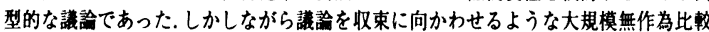
試埃は現在のところ見当たらない。当科では直渴脱治㙩に際して始めに意志決定のト タマを決めそれに徉って治廉を行い，既往症，バフォーマンスステイタス，随伴病変， 排便㙨能を判断材料として患者の振り分けを行い1997年以来 20 例に対して手術を 行ってきた(同一症例の再発 1 例を含む)。内訳は Gant-Miwa-Thiersch 法 1 例, De-

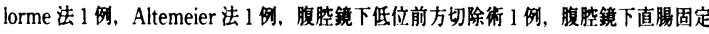

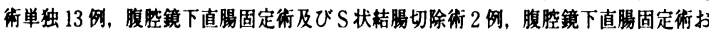
よび total pelvic floor repair 1 例である. 意志決定橵はもとより大规模試験を経て求

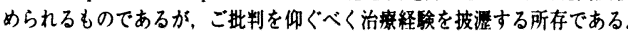

PPS-3-241 直晹脱に対する腹腔鏡下直腸固定術（Wells 変法） 川村英伸"，佐々木章"，須藤隆之”，旭 博史"，斎藤和好" (岩手医科大学第 1 外科", 盛岡市立病院外科" ${ }^{2}$ )

直腸脱に対する複合メッシュを用いた腹㓐镜下直晹固定術 (Wells 変法)を施行し 良好な成嘖を得たので報告する。対象は完全直腸脱（Tuttle II type）の 4 (男性

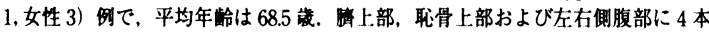

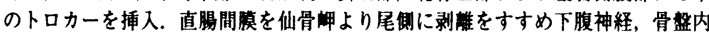
神神経を温存し直腸後方を䎵骨直晹筋の高さまで展開した，e-PTFE シートとボ リプロビレンメッシュの楼合メッシュ（Bard Composix Mesh）を $8 \mathrm{x} 5 \mathrm{~cm}$ の棈円 形に切り，e-PTFE シート僛を直腸側にして仙骨战〜第 2 仙骨前面にヘルニアス テイブラーで固定後，腹镜湅転部の直腸壁を仙骨㶲まで引き上げ，吸収系を用い てメッシュと直晹壁を固定した(メッシュは直腸の約 $1 / 3$ 周を被䨢)。平均手術時 間は 169.5 分, 平均出血量は $28.5 \mathrm{ml}$. 全例術後 1 日に経口掑取, 歩行が可能であつ た. 術後在院日数の中央值は 12 日であった. 1 例に術後排尿障害を認めたが保存 的に改善した，直腸脱に対する複合メッシュを用いた腹胫鏡下直腸固定術は低侵 慗で短期成耤に優れており直晹脱に対する根治手術として有用である。

\section{PPS-3-242 腹腔鏡下直腸脱手術の経験}

根本一彦，國場幸均，中村隆俊，佐藤武郎，井原厚，大谷剛正， 渡连昌彦

(北里大学外科)

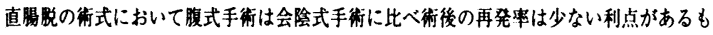
のの手術侵裝の大きさから高䕆者や合併症のある患者で会陰式手術が選択される䫅向が

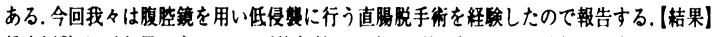

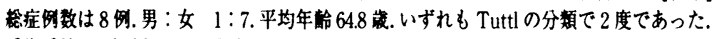
手街手技は, 腹整鏡下にて行う Sudek 変法である.4 ボートでSD-junction 付近から腹膜

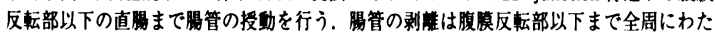

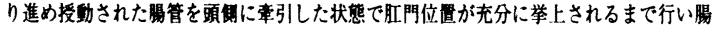
管は仙骨解角周囲に3 4 4 鿕固定し手術を䅂了とする。平均手術時間 $187.4 \mathrm{~min}$, 平均出血 量 $10.7 \mathrm{ml}$, 平均郝後在院期間 9.5 日，経口椇取までの平均期間は 3.5 日。再発は 1 例に認

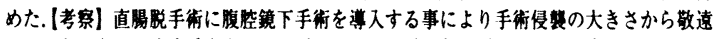
されがちであった腹式手街をボート㨉入部のみの手術創で低侵熋に行う事が可能であっ

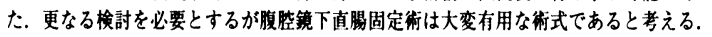

PPS-3-243 完全直腸脱に対する腹䐒鏡下手術 + Thiersch 法 内藤 稔, 佃 和憲, 太田徽哉, 村 1 . 正和, 清水信義 (岡山大学大学院腫場・胸部外科学)

【はじめに直腸脱は比較的まれな疾患であるが，致死的な疾患でないため良好 なQOL が得られる手術が必要である。我々は，腹㓐鏡下手術により直腸脱を修 復後, Thiersch 法を追加し良好な䊅果を得ているので報告する. (手術方法】1) 腹胫鏡下手術：全身麻醉・気腹下に 4 ports 法で行なう。直晹を後腹膜下筋膜の 腹㑡の層で直腸固有筋膜・下腹神释を椇倁しないように全周を剥離する．剥離 後, Marlex Mesh を直腸前碚を残し巻きつけ presacral fascia に䋖合固定する. 2) Thiersch 法：2-0のナイロン禾を用い，肛門に挿入した示指の第 2 関節の位 置で秥禁する. 【結果】 1999 年 5 月 2003 年 12 月までの 4 例. 男性：1 例, 女

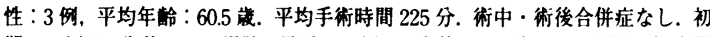
期の 2 例は, 術後 7 日で退院. 最近の 2 例は, 術後 3 日, 術翌日に退院. 観察期 間は, 4 年 8 ケ 3 ケ月であるが, 全例再発なく良好な QOL が保たれている. 【まとめ】直得脱に対する腹腔鏡下手術+Thiersch 法にて良好な結果が得られ た．術後の回復も早く，全身麻酥が可能な症例には適した術式と考えられた。
PPS-3-244 完全直腸脱 16 例の治療経験

徳原太豪"，金澤景繁"，坂田親治"，藤田みゆき"，西川隆之"， 大杉治司 ${ }^{2}$, 東野正幸 ${ }^{3}$

(浅香山病院外科"), 大阪市立大学消化器外科 ${ }^{2}$, 大阪市立総合医療七ン 夕一消化器外科 ${ }^{3}$ )

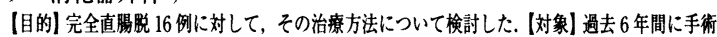

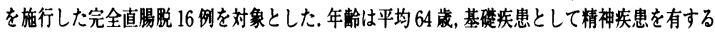
のは8例であった。 全例に直腸の脱出が認められ，嵌頓が1例にみられた。肛門部不快感は全例 にみられ，排便時有は7例，排便後出血は 10 例にみられた。便秘は 11 例にみられた。手術術式 はSudeck 法を 5 例に, Ripstein 法を 9 例に施行した. 1 例にS 状格腸切除, 子宮全摘術を行い，

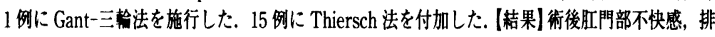
便時痛および排便後出血は全例軽快した。排便状況は縟下都を娍量できたのが 2 例，逆に增量し

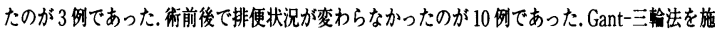
行した 1 例が 1 年 8 力月後に再発を認めた。 はとめ) 1 開腹下手術を施行した症例では, 症状は 全例轻快したが排便状況に明らかな改善はみられなかった，2.Gant一三軨法を施行した1例に再 発が認められた，以上より開腹下に直晹を固定する手技が有用であると思われた．

PPS-3-245 Soiling を伴った 75 歳以上高齢者直腸脱の陰部神経・暃 㖪神経伝導時間について 富田凉一", 藤崎 滋", 池田太郎 21 , 朴 英智2), 五十嵐誠悟"1, 柴田昌彦" ${ }^{2}$, 丹正勝久 ${ }^{2)}$

(日本歯科大学外科", 日本大学第 1 外科2)

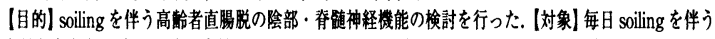

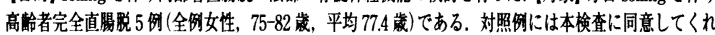

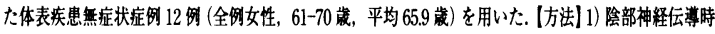

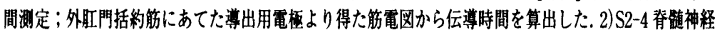

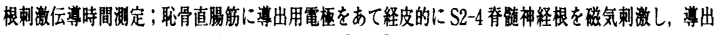

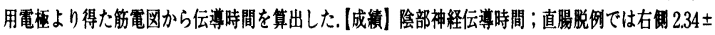

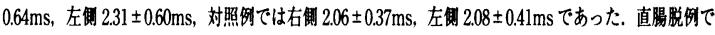

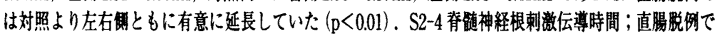

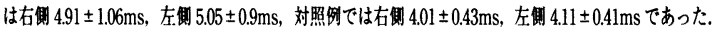

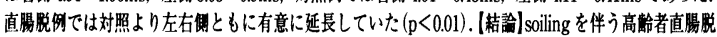

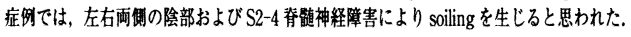

PPS-3-246 ストーマ腸管脱出に対する Gant-三輪変法の有用性 兼田健一郎, 砝 彰一, 的場勝弘, 長島 淳, 松岡功治, 丹黑 章, 岡 正朗 (山口大学第 2 外科)

（はじめに）ストーマ晹管脱出に対して腸切除や腹壁固定が行われるが，いずれも侵襲が大 きい.今回ルーブ式回腸人工肛門脱に対して Gant-三輸変法を施行し良好な成績を得たので 報告する. (症例) 39 才男性. 直腸癌合併潰場性大腸炎に対し低位前方切除術・左半結楊切除

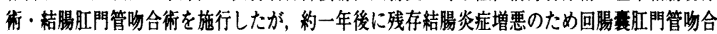
術・ルーブ式回晹人工肚門造設術を施行した，以後，本人希望により人工肛門閉鎖術は行っ ていない，経通中に人工肛門脱が增要し約 $7 \mathrm{~cm}$ となった。(術式) 直腸脱に対する Gant-三古

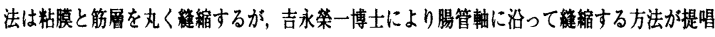
された，本法をストーマ腸管脱出に対して応用した．まず，脱出晹管の腹胫渭寄りから腸管

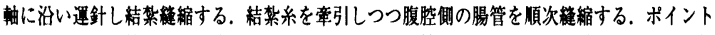
は, 一つ一つの緥縮を大きくしないこと，同心円上の管脂に対して維縮を重ねないこと，外

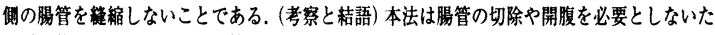
め低侵裂であり，ストーマ腸管脱出に対してまず試みるべき術式であると考えている。

PPS-3-247 急性出血性直腸潰激 9 例の検討（栄養不良との関連につ (て)

福井康雄, 谷木利勝, 山川 卓, 梶浦耕一郎, 八木 誠, 中村敏夫, 児嶋恵美子

(高知市立市民病院 外科)

【緒言】急性出血性直腸潰湟 (以下本症)を経験し，烸床的に検討した.【対象】大腸内視 镜検査にて本症と診断した 9 症例. [結果! 平均年柃 71 才 $(54 \sim 92$ 才), 男性 5 例, 女性 4 例. 基碳疾患は媵血管障害 3 例, 㿋症例, 心・血管術後症例が各々 2 例. 8 例は自力歩 行不能. 坐菜使用者 2 例, 慢性便秘 1 例. 謴湟は全例下部直腸にあり, 形態は露出血管有 4 例, 不整型 3 例, 小円形型 1 例. 治療は䋖合止血 4 例, 内視鏡下クリッピング 2 例, 保 存的治療 3 例. 再出血は 4 例で, 3 例は原疾患にて死亡. 下血前の血清アルフミン值 (以 下 Alb）は は $2.9 \pm 0.8 \mathrm{mg} / \mathrm{dl}$ (低栄養基溸 $3.2 \mathrm{mg} / \mathrm{dl}$ 以下)，総りンパ球数は $1597 \pm 480$ (低栄 養基準 1000 以下). 8 例中 5 例の Alb は低栄盖基汻以下であった. [考察] Alb は栄養指標 の一つであり, 栄着不良が本症における潰場形成・出血に関与している可能性が示唆され た. 再出血後死亡した 3 例の Albは $2.4 \pm 0.26 \mathrm{mg} / \mathrm{dl}$ と著城しており, Alb は基磪䣒患の重

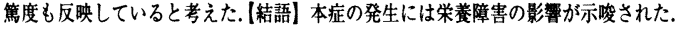


PPS-3-248 結腸-直腸穿孔症例 8 例の検討

小山田尚, 村上雅彦, 矢野英史, 米山幸宏, 殿塚規雄, 中野知之, 尾崎雄飛, 藏本純一

\section{(岩手県立大船渡病院外科)}

当院において 2003 年 7 月から 2004 年 1 月まで結腸一直腸穿孔症例を 8 例経験した. 年龄は 68 才から 83 才, 男性 4 例, 女性 4 例であった. 部位は上行結腸 3 例, 横行結 晹 1 例, S 状結腸 1 例, 直腸が 3 例であった。 原疾患は悪性腫瘍 4 例, 款室 1 例, 特 発性 3 例であった。いずれも穿孔部を含めて周囲腸管を切除，口側に人工肛門を作成 したのが 5 例, 3 例にて吻合を行っている. 術後, 5 例が人工呼吸管理となり，さら に敗血症, 乏尿, 白血球娍少などの症状が見られた症例の 4 例にはCHDF を装着し ている. 発症後 2 日経過し, 術前より呼吸不全, ショック状態を呈し, Mannheim Peritonitis Index (MPI) が 39 であった 1 例を術後 1 日で失っているが，他の 7 症例 は外来通院中である，結腸一直晹穿孔は重篤な病態であり，死亡率も高かったが，薬 郕によるサイトカインの抑制, CHDF, エンドトキシン吸着などにより救命される例 が增えてきていると考えられる，予後には発症から手術までの時間が重要と考えら れたが, 症例数が少ないものの, MPIも予後予測に有効であると考えられた.

\section{PPS-3-249 特発性大腸破裂 16 例の検討}

相 顥成，金田 古田昭彦，石井 正，石橋 悟，後藤 均, 初貝和明, 工藤博典, 横山元昭

(石巻赤十字病院外科)

(はじめに）週去 10 年間の特発性大腸破裂 16 例の背景・治庩・予後について梌討した（対象と 治度）大腸穿孔 49 例のうち特発性大腸破裂 16 例 (32.7\%) を対象とした。男女比は $9: 7$ で, 年

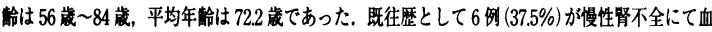

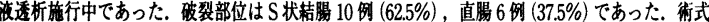

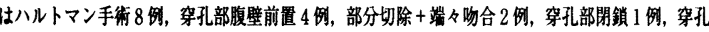

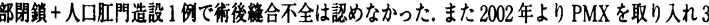

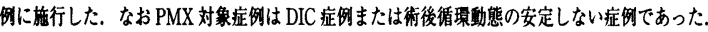

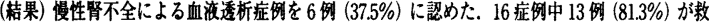
命でき，多炜器不全で死亡した 3 例は全例血液透析症例であった：またPMX症例では 3 例中 2

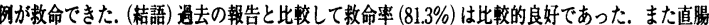
発生例の報告は 5 10\% と非常に稀であるが当院では $37.5 \%$ が直腸発生例であった。透析症例に 大腸破裂が多い要因としては透析患者に便秘患者が多いことが一因ではないかと推察される。

PPS-3-250 大腸穿孔 20 例の検討

日高秀樹，上田祐滋，長岡克弥，下䓢孝司，豊田清一 (県立宮崎病院外科)

目的 : 大腸穿孔は此䡈的稀であり，腹腔内遊離ガス像の出現率が低いためにしばしば 診断が途れ，致死的な経過をたどる．今回我々は大腸穿孔症例について臨床的検討を 行った. 方法：1991年1月から 2003 年 12 月までに当科で手術された大腸穿孔 20 例 について，穿孔の原因，穿孔部位，臨床所見，手術術式，予後について検討した. 粘果 : 大晹穿孔は高血圧や糖尿病, 腎不全などの基碳疾患を有するものに多く，原因は悪性腫 瘍 4 例，息室 6 例，炎症性 2 例，医原性 5 例，外伤性 1 例，特発性 2 例であった。穿孔 部位はS 状結腸か 10 例と最も多く, 直腸 5 例, 盲腸・上行結腸 3 例, 横行結腸 1 例, 下行結腸 1 例の順であった. 腹胩内遊離ガス像の出現率が低く, 術前ショック症状, 白 血球娍少を伴っている症例が多かった. 死亡例が 4 例あり，いずれも敗血症から DIC, 多腈器不全に陥ったものであった，大腸癌穿孔は 3 例あり，全て一期的切除と人工肍門 造設術が施行された．全例が根治度 Aであり，無再発生存中である. 考察：大腸穿孔 では術前からの全身管理と感染症対策にもかかわらす術後合併症が高率であった。 大 晹癌穿孔症例では治莺切除が可能ならは，一期的切除を心がけるべきと考えられた。

PPS-3-251 当院における下部消化管穿孔例の検討

野坂仁愛，豊田啺彦，若月俊郎，竹林正孝，鎌迫 陽，谷田 理 (山陰労災病院外科)

（はじめに）消化器外科において今なお下部消化管穿孔は致死的に陥る場合があり， 治豦も難涉する.今回われわれは当院での下部消化管穿孔例に対し，どのような場合 に致死的になるかをまたどのようにすれば回避できるかを検討した（対象）過去 5 年間で手術した下部消化管穿孔 24 例を対象とした. (結果) 穿孔の原因と部位では, 特発性が 10 例と一番多く，部位では $S$ 状結腸 8 例直腸 5 例と下部大渴に多かった。 生存例，死亡例における年龄を比㜞すると死亡 9 例の平均年龄 82.3 歳生存 15 例の 平均年龄 53 歳と有意に死亡例に高かった。 また，発症から手術までの時間をみると 死亡群 37.4 時間生存群 5.5 時間と死亡群が長かった．次に術前の併存疾患の保有率 をみると死亡群 $66 \%$, 生存群 $26 \%$ と死亡群に高かった。腹腔内に漏れでた便の性状 をみてみると硬い便は 13 例 (2) 軗性の便は 4 例 (2) ペースト状便は 7 例 (5) 見ら れ，死亡例（）内はぺースト状に多かった（結語）下部消化管穿孔例に打いては高橉 者 $(80$ 葴以上)で手術までの時間が半日を超え（便汁にさらされる期間が長い），併 存疾患を有している者は術後多腫器不全に陥る可能性が非常に高いと思われる。
PPS-3-252 大晹穿孔 17 例の検討

太田博彰, 太和田昌宏, 松井 聡, 福井貴已, 河合雅彦, 國枝克行, 古市信明，三澤恵一

(岐阜県立岐皋病院外科)

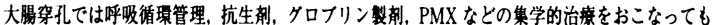
その甲斐なく死亡する症例を経输する。当院で平成 11 年 1 月加ら平成 15 年 12 月までの 5 年間

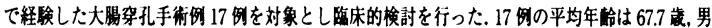

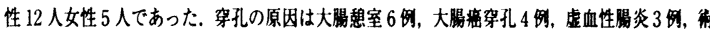

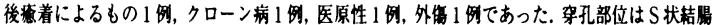

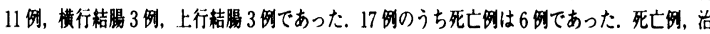

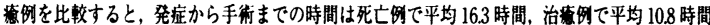
であった，手街まで 12 時間以上要した症例の $57.1 \%$ は死亡した。また 12 時間以内に手術した 症例の $75 \%$ は救命しえた。術前白血球数仗死亡例で平均 $5033(1200 \sim 14400)$ ，治事例で 10109

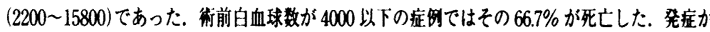
ら手術までの時間と術前白血球数の低下との間に相関は見られなからたが自血球数が低下する

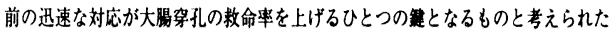

PPS-3-253 非腫場性下部消化管穿孔症例の検討

松田圭二，安達実樹，味村俊樹，筦井武和，矢後尋志，大見环磨。 白 京剖, 野澤慶次郎, 小平 進, 冲永功太 (帝京大学外科)

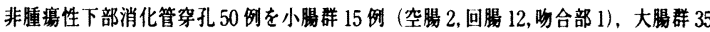

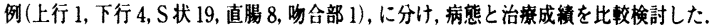

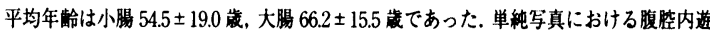
離ガス像の出現率は，小渴 $50.0 \%$ ，大腸 $84.6 \%$ であった，穿孔の原因は，小渴ではべー

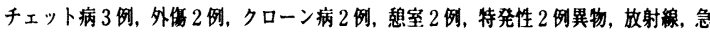
性虫垂炎，閉鎖孔ヘルニアが各 1 例であった，大晹では想室 14 例，内視鏡 7 例，特叒

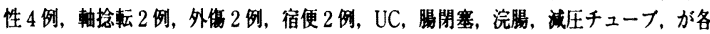
1例であった. 術式は小腸では全例に穿孔部腸管切除吻合が行われた，大晹では，ハル

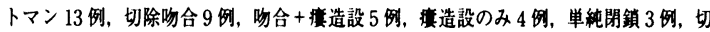
除十瘦造設 1 例であった，術後合併症は小腸では 4 例 $(26.7 \%)$, 大晹では 28 例 $(80.0 \%)$ であった，死亡例は小㔠が 2 例 (13.3\%)，大腸が 7 例 $(20.0 \%)$ であった。術後合併症 は大腸に多く，創感染，呼吸器合併症，DICの十分な对策が必要と考えられた。

PPS-3-254 左側大腸穿孔の検討

金丸隆幸，川元俊二，稲田一雄，野田尚孝，木田吉俊 (福岡德洲会病院外科)

目的：左側大腸穿孔は，沉発性腹膜炎, 敗血症性ショック, 多腈器不全一 と急激に変化し子後不良である. 我々は, 1996 年から 2003 年の 8 年間に 経験した左側大晹穿孔手術 37 例（医原性を除く）について検討し，報告 する，対象 方法：年龄 病恼期間 原因疾患 基磷疾患 開腹所見 手術時間 術式 術後 APACHE2 スコア等を, 生存症例, 入院中死亡症 例に関し検討した，結果：18歳から96歳平均年龄 65 藏 男性 22 例 女性 15 例. 原因疾患特発性 16 例 想室性 8 例 悪性腫鸤 6 例 外侮 性 2 例. 開腹所見 被覆穿孔 14 例（死亡例 1 例）遊崔穿孔 23 例（死亡例 11 例). 術式 ハルトマン手術 21 例 S 状結腸切除術 5 例 単純開鎖 5 例 人工肛門のみ 2 例であった，特に開腹所見の状態により術後生存の可能 性が左右された，結語：左側大腸穿孔は現在でも死亡事が高く遊崔穿孔 は被覆穿孔に対し著明に救命事が低かった。 また, 遊離穿孔に関し, 高龄, 基磷疾患有し，術後高いAPACHE2 スコアの場合死亡事が高かった

PPS-3-255 非外倁性左側大晹穿孔に対する手術症例 35 例の検討 平䗁重雄, 桶上 健, 石丸神矢, 大可俊郎，長野裕人，松木盛行。 嘉和知靖之, 丸山 洋, 栗栖 茜, 洼田孝藏

(武藏野赤十字病院外科)

(対象・方法) 1999 年から 2003 年までの 5 年間に当科で手術を行った非外伤性左㑡大渴 穿孔 35 例を生存群 (A 群 29 例) と死亡群 (B 群 6 例) に分類し, 術前状態・烸床検査成

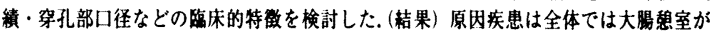
もっとも多く(18例)，整が続いた(11 例)。発症から手街までの時間は A 群で $39.6 \pm 37.1$

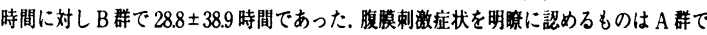
は $73 \%$, B 群では $50 \%$ であった，術前の血液桱査では白血球数， BE 值で B 群に低值を 記めた， B 群では術前 XpあるいはCTで全例に free air 碓認でき，6例中 5 例で術前

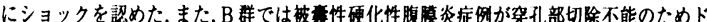
レーン留置のみ施行し 12 病日に腹暁炎により死亡し, 残り5例は穿孔部切除・人工肛門 造設か行われたが全て術後20 時間以内に死亡した（考察)予後の判定に際し，手術まで の経通時間や腹膜刺激症状は指標になりにくかったが、ショックの程度と白血球数，BE 值はその時点の腹募炎の程度を反映しており指摽として有用であると思われた。 
PPS-3-256 大腸穿孔の重症度における対処法の検討 井上達史, 増尾光樹, 熊谷一秀, 清水浩一, 横川 登, 相田貞継, 島田恵太

(昭和大学豊洲病院外科)

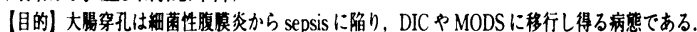

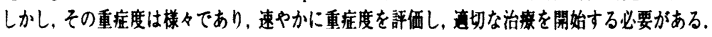

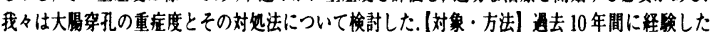

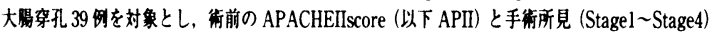

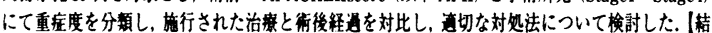

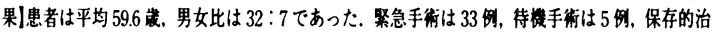

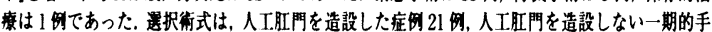

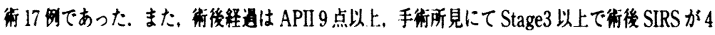

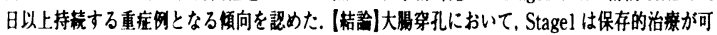
能であるが, 释皮的ドレナージの不可能な Stage2 やStage3以上は手術息応と考えられた.また，

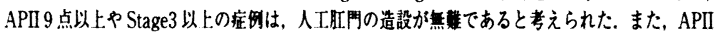
13 点以上やStage4の症例は血湖争化などの集中治㞠の必要性が示唆された。

\section{PPS-3-257 直晹原発 malignant rhabdoid tumor の 1 例}

中山 中, 辻本和雄, 伊藤意雄, 竹内信道, 松下晶充

(伊那中央桧合病院外科)

症例は 63 歳，男性. 平成 15 年 10 月下血を自覚して近医を受診. 直腸瘦の疑い で, 10 月 14 日当院を紹介された，大晹内視鏡検査にて肛門縁より約 $10 \mathrm{~cm}$ の直 腸前壁に易出血性の1 型庫瘦を認め，生検では Group5, 低分化型腺雷が示唆さ

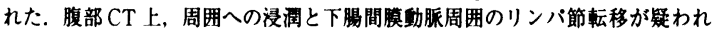
た. 11 月 28 日直腸瘦の診断で手術を施行した。腫借は骨盤にはまり込むように 存在しており,膀㜆と密着していた. 肝転移, 腹膜播種は認めなかったが, №.253 リンバ節転移を認めた，手術は直腸前方切除，人工肛門造設術(ハルトマン)を 施行した. 肉眼所見は直晹 $\mathrm{Ra} \sim \mathrm{Rs}$ に徍 $10.0 \mathrm{cmX} 8.4 \mathrm{~cm}$ の不正形, 粗大分葉状の

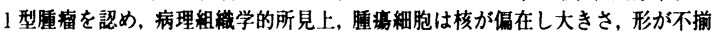
いな胞対を持ち，細胞間結合性の乏しさが特徽であった．サイトケラチン $20 \%$ $(+)$, S-100 (-), ビメンチン (+), LCA (-), これらの所見から直晹原発 の malignant rhabdoid tumor と診断した. 直晹原発の本疾患は検索しえた限り ただ1例の報告があるのみで，きわめて稀な疾患と考え報告した。

PPS-3-258術前検查で正診できなかった上行結腸原発 Neuroendocrine carcinoma $の 2$ 例

濱田英明, 清田正之, 万代康弘，山野寿久

(岡山市立市民病院外科)

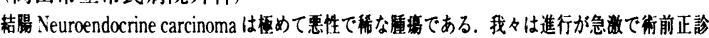

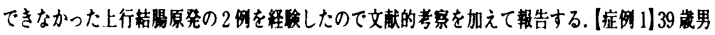

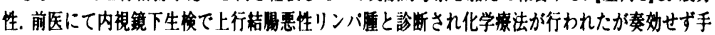

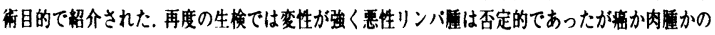

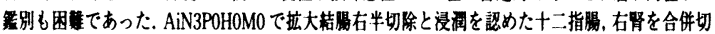

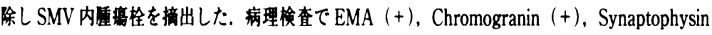

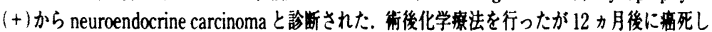

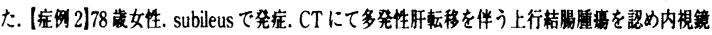

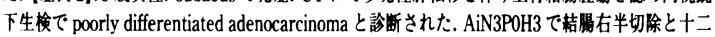

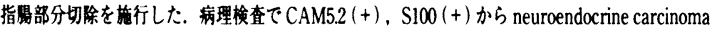

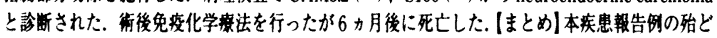
が進行盘で術後早期に死亡しており的碓な診断法と集学的治㙩法の確立が望まれる。

PPS-3-259 ITPを合併した上部直腸缯イレウスに対し二期的に手術 を行った 1 例

三谷英信 ${ }^{12}$, 辻 和宏”，池田宏国"，齐藤 諴”，安藤隆史 ${ }^{11}$, 平川栄一郎 ${ }^{2}$

(屋島総合病院外科"，香川県立医療短期大学医床検査学科 ${ }^{21}$ )

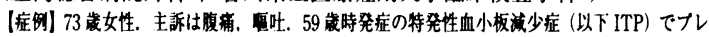
ドニソロン(以下 PSL) 内服中. 腹部 XP で消化管全体の搪張像と CT で直晹 Rs 部全周性㹟窟,

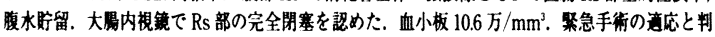

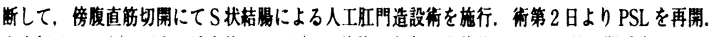
血小板は 5.6 万 $/ \mathrm{mm}^{3}$ まで沙少後, 10 万 $/ \mathrm{mm}^{3}$ 前後に安定. 術後第 21 日目に第二期手街として,

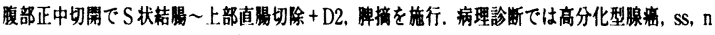

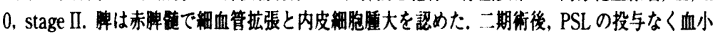

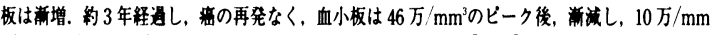

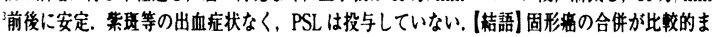
れとされているITPを合併した上部直閶峦イレウスに対し，侵䈨の少ないように二期に分けて 手術を行い，二期目で根治街と脾㜔を行うことで良好な成彎が得られた。

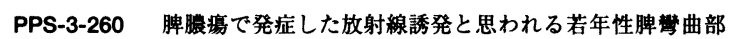
結晹癌の一例 田村利尚, 永田直幹, 日暮爱一郎, 鶴留洋輔, 平田敬治, 中山善文, 岡本好司, 小西鉄巳, 伊藤英明 (産業医科大学第 1 外科)

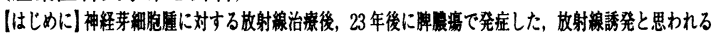

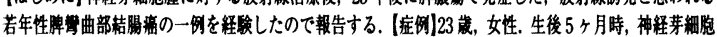

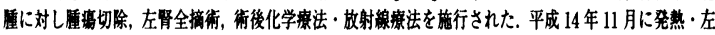

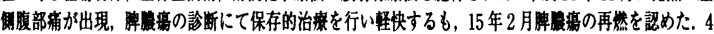

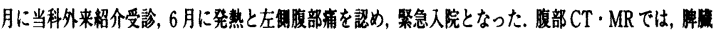

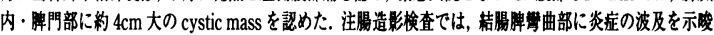

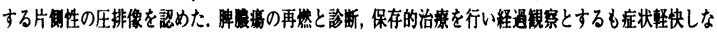

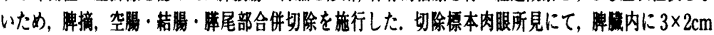

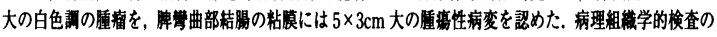

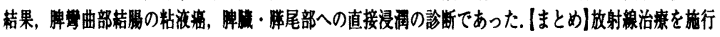

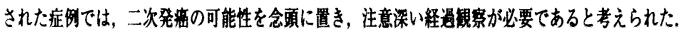

PPS-3-261 治療抵抗性の深部静脈血栓症を伴った直腸癌の一例 原田栄二郎, 重田匡利, 折田雅彦, 楆 忠彦, 野島真治, 濱野公一 (山口大学第 1 外科)

担瘦患者に血栓症が合併することは古くから指摘されている.深部静腺血栓症を発症

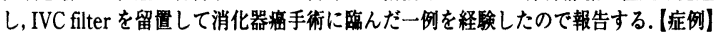
59 藏男性. 平成 15 年 6 月下旬に特に誘因無く左下肢腫脤および疼蒲を主訴に近医受 診.深部静脈血栓症の診断で当院救急部を受診した. (入院後経過】血栓摘出術施行し， temporary IVC filter を留置した. 線溶・抗凝固察法が奏功し, 第 5 病日に filter を抜 去した. その後, CT で指摘された直晹癌の精査を行い一時退院とした. 退院 1 週間 後, 右下肢腫脹および疼傅を主訴に当科受診. 血液検査では warfarinの効能が確認さ れた一方, D-Dimer は上昇しており，数固能元進状態であった.【再入院後経過】血栓 摘出術施行し, permanent IVC filter を留置した. 抗凝固療法で速やかに郜床症状は 消失し, 直腸㿋手術を施行した. 術翌日から抗凝固療法を行い, 肺塞栓症の兆候無く, 部床は速やかであった，その後，血栓症再発の兆候は認めていない.【考察】担癌患者 は, 就細胞が産生する血小板数集物質や颣固促進物質により凝固元進状態となること が原因とされている，本症例においても直腸癌が血栓症の誘因と考えられた.

PPS-3-262腫堭径 $15 \mathrm{~mm}$ で発見された大腸腺扁平上皮癌の 1 例 山本哲朗, 湊 あこ, 柳沼行宏, 石戸保典, 武田良平, 渡部 英, 苜野雅彦, 冨木裕一, 坂本一博, 鉡野俊紀

(順天堂大学 消化器外科学講座 (下部消化管外科) ) 大晹の腺扁平上皮癌は比較的まれで, 本邦報告例では大きな腫瘦として発見され るものが多い. 今回われわれは，腫㓊径 $15 \mathrm{~mm} て ゙$ 発見された大腸腺扁平上皮癌の 1 例を経験したので報告する. 症例は 65 歳, 男性. 1982 年 $\mathrm{S}$ 状結腸癌で $\mathrm{S}$ 状結渴 切除術を施行された. 以降, 多発大腸ポリープため定期的に大腸内視鏡検査を 行っていた. 2002 年 3 月に EMR 施行したポリープのひとつに腺腫内腺癌を認 め, 組織型は高分化腺癌, 深達度は sml であった. 2003 年 11 月の検査で, 横行結

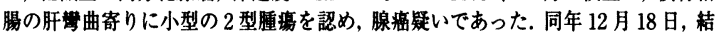
晹右半切除術を施行. 病理診断で腫疸はいわゆる腺扁平上皮癌で, 腫掝径は $15 \times 12$ $\mathrm{mm}$ ，深達度は mpであった．また，迋晍転移およびリンパ節転移は認めず，術後 経過良好で, 第 12 病日に退院し現在外来通院中である. 腺扁平上皮癌の報告例の 多くが大きな腫䚀を形成し, リンバ節転移を伴う進行癌であるが, 自験例は早期癌 ではないものの, 小さい腫嘴のうちに発見された興味深い 1 例と思われた.

PPS-3-263 Bruton 型 $\gamma$ グロブリン血症に合併した多発大腸癌の一 例 岡本和哉"，木村泰三 ${ }^{11}$ ，梅原靖彦"1，鈴木憲次 ${ }^{12}$ ，奥村拓也 ${ }^{11}$, 川端俊貴 ${ }^{1}$ ，小宮山明 ${ }^{21}$

(富士宮市立病院外科 ${ }^{11}$, 富士宮市立病院病理科 ${ }^{21}$ )

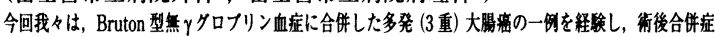
なく管理しえたので报告する。患者は 45 歳男性. 2 歳時より気管支炎を繰り返し, Bruton 型鳘 $\gamma$ タロフ

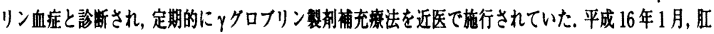

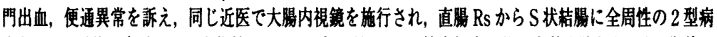

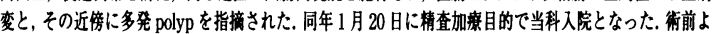

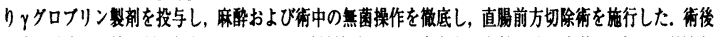

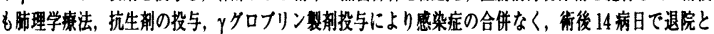

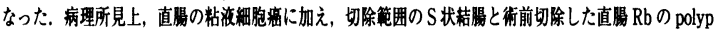
に其に高分化腺需を認めた。本症は消化器篦を合併しやすいと報告され，その機序として細菌感染によ る僈性炎症による剌滰の関与が考えられている。 また，本疾患の周術期には

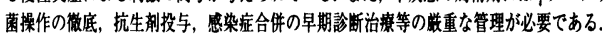


PPS-3-264 若年性巨大大腸癌根治切除後 7 ヶ月目に巨大後腹膜腫瑒 を発症した一例

篠原育代，岩城堅太郎，吉田 晋，吉永敬士，大田隆司，甲斐哲司， 金子 聡, 穴井秀明, 野田尚一

(国立大分病院外科)

【はじめに】大腸癌街後再発は，肝転移や、リンバ節転移，腹膜播種などで発症するのが一般的であ る. 今回, 我々は若年性巨大大晹癌根治切除後 7 ヶ月目に巨大後腹膜腫膈を発症し, 切除標本にて大

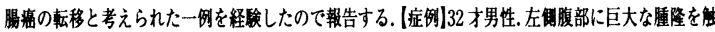
知し, 精查の蛣果，横行絓腸中央やや脾湾曲部よりに約 $20 \mathrm{~cm}$ 大の低分化型の大胆癌を認めた，中結

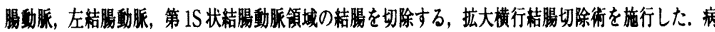

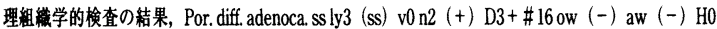
P0M (-) stage3B curA であった. 街後補助化学㙩法として, CPT- $1180 \mathrm{mg} / \mathrm{m} 2+L V 30 \mathrm{mg} / \mathrm{m} 2+$ Bolus $5 \mathrm{FU} 500 \mathrm{mg} / \mathrm{m} 2 /$ Week 3 投 1 休で 4 クール施行した.4 クール終了時に腹部CTにて再発な

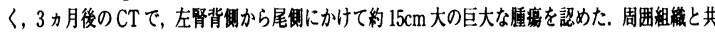

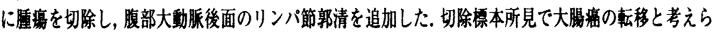
れた.はとめ非常に稀な再発形式と考えられたので，文献的考察を加え報告する。

PPS-3-265 大腸癌原発巣非切除症例に対する全身化学療法の経験 水島恒和, 山東勤弥, 位藤俊一, 三方彰喜, 野中健太郎, 井手春樹, 道浦俊哉, 甲斐沼尚, 山中宏晃, 岩瀬和裕

（市立泉佐野病院外科）

大得癌原発单非切除症例に対し, 5-FU/LV 療法が著効した症例を経験した. 79 才, 男性.

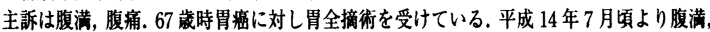
腹痛を自覚していたが放置していた. 10 月注腸造影, 大腸内視鏡検査にて横行結腸中央部 に全周性 3 型病変を指摘され，生検にて中分化型腺㿋と診断された，開腹時の所見で腫疱 が胃全摘術後再建に挙上した空腸の晹間膜に浸潤していたため,切除は断念し口側に人工 肛門のみ造設した，術後LV/5-FU 療法を開始した．薬郕投与量は高龄であること，術前 全身状態が不良であったことを考慮し $5-\mathrm{FU} 450 \mathrm{mg} / \mathrm{m}^{2}, \quad$ LV $200 \mathrm{mg} / \mathrm{m}^{2}$ とやや娍量した. 4 クールの LV $/ 5-\mathrm{FU}$ 療法が終了した時点で大晹内視鏡, 腹部 CT 検査を施行したところ,

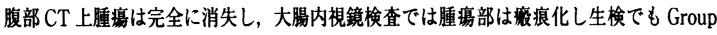
1 と腫演細胞を認めなかった. また治療期間中を通じ手指の色素沈着以外に特記すべき副 作用は認められなかった.大腸瘭原発巣非切除症例といえども全身化学療法により予後改 善が期待できる症例が存在し, 薬剂投与量調整等の工夫が必要であると考えられた.

PPS-3-266 当院における進行・再発大腸癌に対する外来 $1-L V / 5-$ $\mathrm{FU}$ 療法の有用性についての検討

豊川晃弘，若原智之，辻村敏明，中村吉貴，加地政秀，塚本忠司，

脇田和幸, 大西律人, 濱辺 豊, 石田 武

(淀川キリスト教病院外科)

(はじめに) 高度進行・再発大腸癌は予後不良で確立され標準療法はないのが現状である，当院で は2001 年より Stage IIIb 以上の症例に対して 1-LV/5-FU療法を外来にて施行しており，今回その 有用性について検討した（対象と方法) 通去 3 年間に当院で絓検した大腸癌手術症例は 271 例で内 訳は Stage IIIb 25 例, Stage IV 38 例である. 今回の対象は進行・再発大晹㾇と診断され I-LV/5FU 療法を1クール以上施行された20例で，性別は男性 13 例，女性 7例，年秢は 40-75歳，平均 56.8 歲である。投与方法は $-\mathrm{LV} 250 \mathrm{mg} / \mathrm{m}^{2}$ と 5-FU 600 mg $/ \mathrm{m}^{2}$ の) 1 回/週で, 6 投 2 休とした. (結果) 主な副作用は下碀 (Gr2 以下)，白血球娍少 (Gr3:2例)，口内炎 (Gr2 以下)，発热 (Gr2 以下) で あり，Gr3の白血球娍少に対しては G-CSF 投与等で対処できた，投与回数は 6-26回で，最長期間 は11月に渡る。効果はPR7例，NC8 例，PD4例であり奏効率は35\%であった. Kaplan-Meier

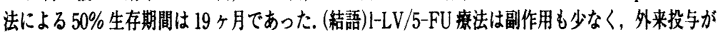
安全に施行可能であった. 奏効率は $35 \%, 50 \%$ 生存期間は 19 ケ月と良好な結果を得た.

PPS-3-267進行・転移再発大腸癌に対する TS-1/low dose CDDP 併 用化学療法の効果

牛山貫文 ${ }^{12}$, 石村 健 ${ }^{1)}$, 唐澤幸彦 ${ }^{21}$, 若林久男 ${ }^{21}$, 前田 綮

(国立療養所高松病院外科 ${ }^{11}$, 香川大学第 1 外科 ${ }^{21}$ )

【はじめに】進行・転移再発大腸癌 4 例に対して, TS-1/low dose CDDP 併用窨法を 行った. [対象・方法] 症例 1) stageIl の 進行大腸癌症例, (症例 2) 原発巣切除後異時 性肝転移に対し 2 回の肝切除術後症例, (症例 3 および 4) 画肺多発転移を伴う直腸㾇 症例. これらの術後に, TS-1/low dose CDDP 併用療法を行った. 投与方法は(TS-1： $100 \sim 120 \mathrm{mg} /$ 日, CDDP : 10mg/週) $\times 4$ 週間投与, 2 週間休薬を1クールとした. (結 果] (症例 1,2) それぞれ術後 10,4 クール施行し, 18,6病月の現在, 転移・再発は認め ていない. (症例 3)5 クール施行し, 両肺の腫瘍は NC〜PD であったが, 肝転移も生じ 他の薬剤へ変更した. (症例 4) 2 クール終了時に腫激マーカーはほほ正常化し, 両肺の 転移巣も画像上縮小し PR となった. 16 クール施行し 30 病月の現在, 転移巣の増大や 新たな転移・再発は認めていない。 また全例で重第な副作用なく，外来治療が可能で あった. [考察]本療法は, 簡便で重篤な副作用もなく, 良好な QOL で外来治療が可能 であった. また著効例も見られ，大腸癌に対して有効な治療法と考えられた.
PPS-3-268 進行再発大晹拜に対する免疫化学併用裳法

笹富輝男", 的野敬子", 大北 亮", 石橋生哉", 唐 宇飛 ${ }^{21}$,

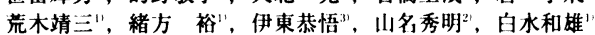
(久留米大学医学部外科", 久留米大学医学部集学治撩センター" , 久留米 大学医学部免疫学教空 ${ }^{31}$ )

本学ではペプチドワクチン瘄法を進行再発大䐉㿋症例を対象とし郎行している. HLA-A24たは HLA-A2 結合ペブチドのうち患者末梢血リンバ球（T緗胞）と反底 性を有するペプチドを 4 種類選択した. 投与方法は不完全フロインドアジュバンド との溶液として大腿部の皮下組蟣内に別々に注射し， 2 週間に 1 回投与した.ささらに 2 週毎にワクチン 3 回投与後，ワクチン 4 回投与後より併用措法として $5 F U （ 750$

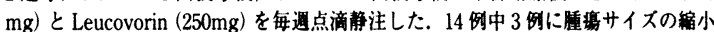
が認められ，ペプチドと 5FU, Leucovorin との併用時において，投与ペプチドに対

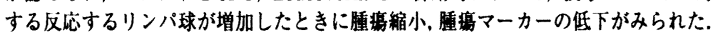

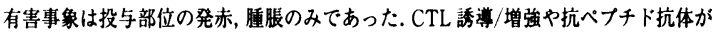
早期から認められた症例に抗腫窎作用を伴う症洌や生存期間が長い症例が多かっ

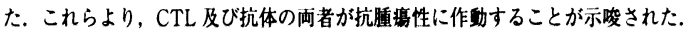

PPS-3-269 stage 3b, 4 大腸瘦切除術症例に対する補助化学療法の検 討

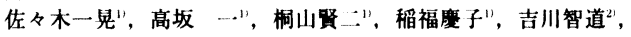
西川紀子"2, 古畑智久 ${ }^{21}$, 秦 史壮 ${ }^{21}$, 平田公一2

(道都病院外科 ${ }^{11}$, 札幌医科大学第 1 外科 ${ }^{2}$ )

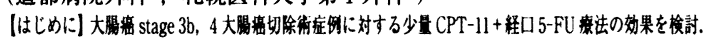

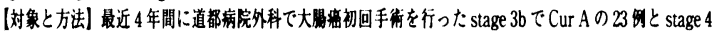

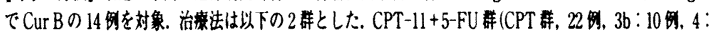

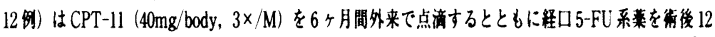

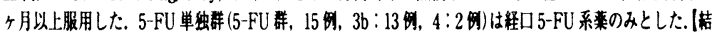

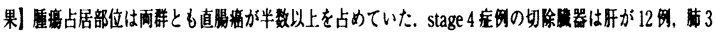

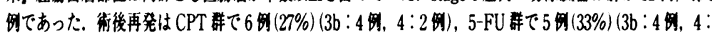

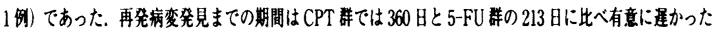

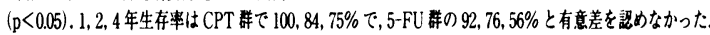

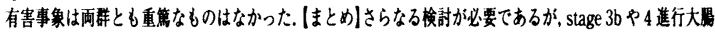

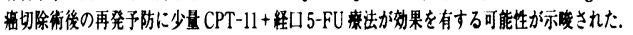

PPS-3-270 生化学的抗腫掝剤アンチネオプラストンの大腸癌術後補 助瘖法としての有用性

的野敬子, 緒方 裕, 荒木靖三, 笹富蟆男, 大北 克, 石橋生哉, 志田誠一郎, 福光賞真, 白水和雄

(久留米大学外科)

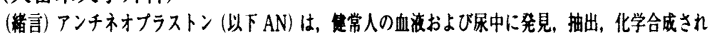

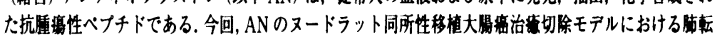

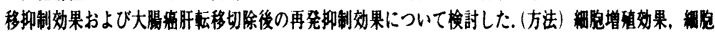

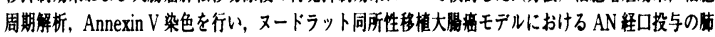

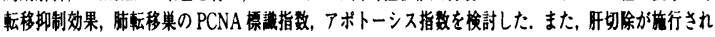

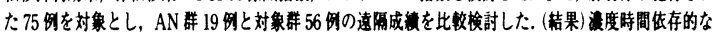

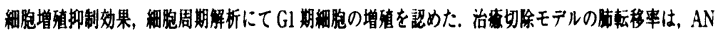

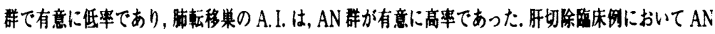

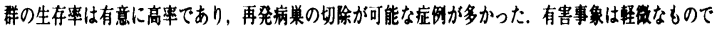

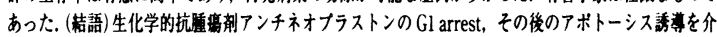

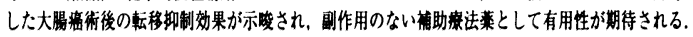

PPS-3-271 大晹瘦における Topoisomerase-I mRNA 発現の半定量 と臨床的意義

石田秀行, 白川一男, 大澤智徳, 中田 博, 猪熊滋久, 檽本大定 (埼玉医科大学総合医尞センター外科)

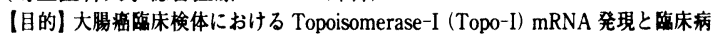
理学的因子との関係, および Topo-I mRNA 半定量の烸床的意義（特にCPT-11 の効果予測)について検討. (方法】腫瘦および隣接正常粘膜を $-80^{\circ} \mathrm{C}$ で涷結保存し 得た大晹癌を対象. Topo-I mRNA の発現は, RT-PCR 法で半定量 ( $\beta$-actin を internal primer). 【結果】(1) 粘膜, 腫场の topo-I mRNA 発現は各々 $0.04 \pm 0.02,0.54 \pm$ 0.10 であった $(\mathrm{p}<0.01, \mathrm{n}=22)$. (2) 12 項目の政床病理学的因子と Topo-I mRNA 発現の間で，有意な関係を認めたものはなかった $(n=120)$. (3) CPT-11に対する Responder $(\mathrm{PR}+\mathrm{CR}, \mathrm{n}=14)$, Non-responder $(\mathrm{NC}+\mathrm{PD}, \mathrm{n}=25)$ の Topo-I mRNA 発現は各々 $0.12 \pm 0.07,0.13 \pm 0.04$ であった $(p=0.83)$. [結詅]瘦部では正常粘㸝に比 へ, Topo-I mRNA の発現が立進しているが, 暚床病理学的因子と発現程度には関 連性がないことが判明した。また，Topo-I mRNAの発現の多赛がCPT-11 の効果 を规定する可能性は低く，他の因子を検索すべきと考えられた。 
PPS-3-272 腄䏒内 COX-2 遺伝子発現量と大腸癌に対する TS-1の 感受性に関する検討

内田数海, 林 和彦, 中島 豪, 高䗁 健

(東京女子医科大学消化器外科)

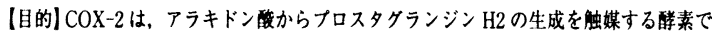
あり、アポトーシスア血管新生に作用し発瘭および㾇の発育に関与すると報告されてい

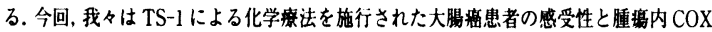
-2 遭伝子発現量との関保について模討した（対象症例と方法】TS-1により化学察法を

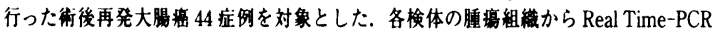
法により COX-2の mRNA 発現量を測定し、TS-1の奏功染および生存期間について検

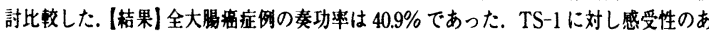
万症略群の COX-2 进伝子発現量は，感受性のない症例群に比べ有意に低值を示した $(\mathrm{p}<0.05) . C O X-2$ 発現量が中央值より低い症例群は高い症例群に比べ生存期間が有意

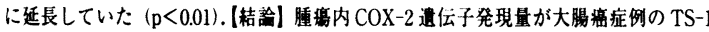
の感受性およひ予後に関与していた，今回の検討により，腫場内 COX-2 遭伝子発現は 大腸瘭の TS-1による感受性および生存期間の子测因子となる叮能性が示唆された。

PPS-3-273 多発性に発生した空晹癌の一例

松信哲朗123. 中島由貫", 大村在幸"，廣田 淳"，森康昭"，

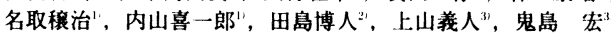
(海老名総合病院外科", 海老名総合永院消化器内科"), 東海大学病理診断 学党)

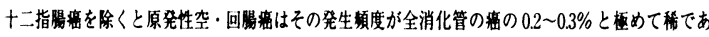

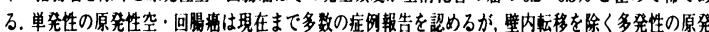

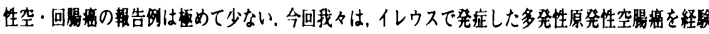

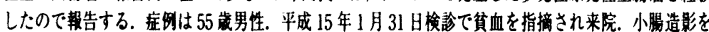

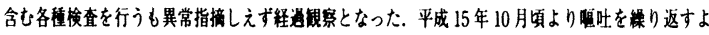

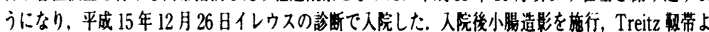

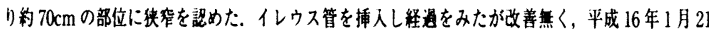

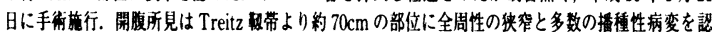

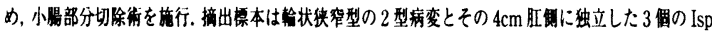

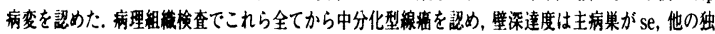

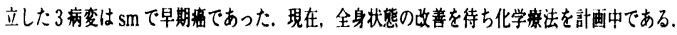

PPS-3-274 原発性空晹癌による成人晹重稆症の 1 例 龍沢泰彦, 木卜静一, 平能康充, 清水淳 (済生会金沢病院外科)

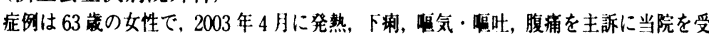
診した，上下部消化管内視鏡梌査，腹部 CT 上は猉常を認めなかった，10月に上部消 化管の閙塞を来し，再度内梘鏡検査を施行したところ，Treitz

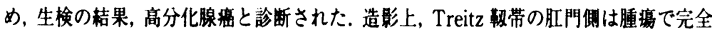
閉塞になっていた，腹部血管造影上，第二空腸動脈が腫凊の栄養動脈となっており，空 腸癌と診断した. 11 月に手術を施行, Treitz带の約 $7 \mathrm{~cm}$ 肛門側の空晹に全周性の腫

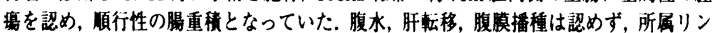

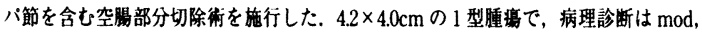
$\mathrm{a} 2, \mathrm{ly} 0, \mathrm{vl}, \mathrm{nl}(+)$ ， ow ( -)，aw (-) であった。原発性小腸富まれで，解剖学的位

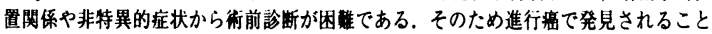
が多く，予後不良とされている，通常の内視鏡梌查や囻像診断で異常がなくても，腹部 症状が続く場合は，本症も念頭においた精査を行う必要があると考えられた。 また小腸

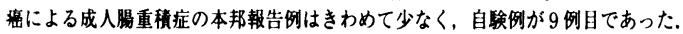

PPS-3-275 原発性小腸癌 7 例の臨床病理学的検討

小林大介，木村次郎，铃木鿆一，金住值人，横井一樹，完山泰章， 市川俊介, 石井正大

(岡绮市民病院外科)

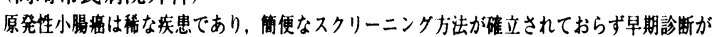

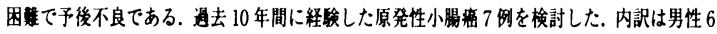

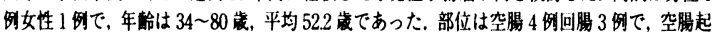

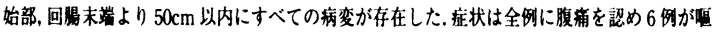

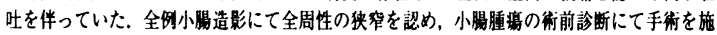
行した. 全例内梘镜下での直梘，生検は行えず，確定診断はつかなかったが，開腹所見にて

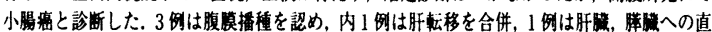

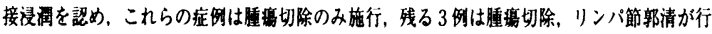

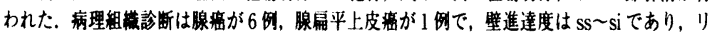

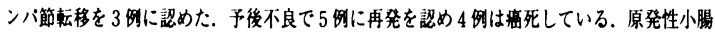

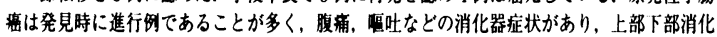
管に異常を認めないときは，棈梅的に小濑造影を行い早期発見することが大切である。
PPS-3-276 術後化学療法が奏効している小腸癌の 2 例 久納孝夫, 佐伯悟三, 谷合 央, 法水信治, 柴原弘明, 坪井俊二, 河原健夫, 服部正也, 横井俊平

(安城更生病院外科)

原発性小腸福は, 比較的稀な疾患で, 進行癌が多く，その予後は不良である. 今回, 進行小晹窥 2 症例に $5 \mathrm{FU} / \mathrm{ILV}$ 療法を施行し良好な経過をとっているので報告する。 症例 1,49 葴, 女性. 平成 14 年 5 月下腹部眥满感, 性器出血のため当院産婦人科受診.

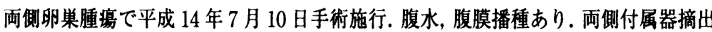

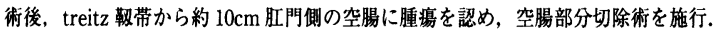
mucinous adenocarcinoma, se, lyl, v0n $(+), \mathrm{p} 3$. 術後 $5 \mathrm{FU} / \mathrm{LLV}$ による化学㙩法を 施行(副作用のため減量), 術後 1 年 7 月再然なし. 症例 2,69 歳, 男性. 糖尿病で近

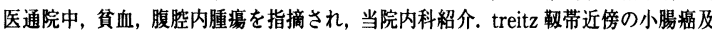
び巨大リンバ節転移の診断となり, 平成 15 年 4 月 28 日手術施行. $100 \mathrm{~cm}$ の空腸切除

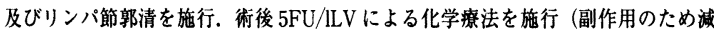
量), 術後 9 月再発なし. 考察, 原発性小腸癌は化学療法の感受性は低いとされてき たが，5FU/LLVによる化学橑法は小腸福にも有効と考えられる.

PPS-3-277 空腸晹重積をきたし術前 CTにて診断し得た極めて稀な 悪性黑色腫の一例

水田有紀，生駒大登，市川大輔，園山輝久，上田祐二，大辻英吾， 系井啓純, 萩原明於, 山岸久一 (京都府立医科大学消化器外科)

腸重積をきたし術前 CT にて診断し得た悪性黑色腫の一例を経験したので報告す る. 症例は 33 耑男性. 背部悪性黑色腫に対し同切除術後加療していたが, 術後 4

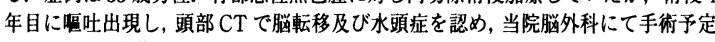

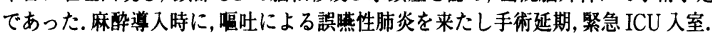
腹部 X 線で胃の著明な拡張認め, 検索目的の腹部 CT で空腸の重積を思わす所見 認め当科紹介, 同日唋急開腹術を施行した。手術時トライツ勒帯より約 $15 \mathrm{~cm}$ 肛門 側に腫場を触知し，同部位を先進部とした腸重皘を認め，用手的解除を試みた。空

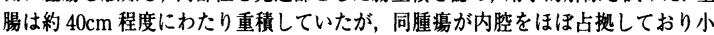
晹部分切除術を施行した. 術後はイレウス症状も改善し, 経口掑取可能となった。 本邦での悪性黑色腫の小晹転移の報告例は，自験例を含め 23 例であり，本症例は 極めて稀な臨床経過をたどったため若干の文献的考察を含め報告する。

PPS-3-278 皮虑悪性黑色腫の小腸, 腹膜転移の一例 片山真史"，櫻井 丈"，朝野隆之"，芦川和広"，野田真一郎"， 花井 彰", 山田恭司"”, 山村卓也", 山口 晋"1, 中野裕子2" (聖マリアン十医科大学消化器外科", 聖マリアンナ医科大学病理学 ${ }^{2}$ )

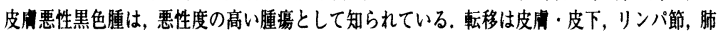
の順に多く、肝, 脱, 骨にもみられるが, これら以外の戥器への転移が認められることは末期 以外では少ない，消化管への軽移は，臨床的に発見されるのは1 7\% と少ない.今回我々は， 悪性黑色腫の小腸，腹膜転移を認めた一例を経駩したので, 若干の文献学的考察を加え報告す る. 症例は 78 歳, 男性. 平成 12 年 1 月, 左滕部の悪性黑色堙にて腫堭切除術施行. 平成 15 年 5 月上旬より下溂, 食思不振出現。便潜血陽性を指摘され，精査加㙩目的にて当院消化器内

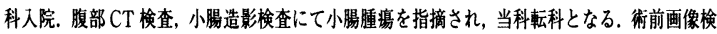

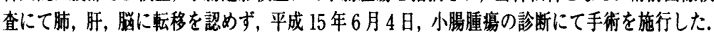
手術所見では，腫堭はトライツ軗带より $110 \mathrm{~cm}$ の空腸腸間膜に存在し，晹管を巻き込むように 存在していた。腫場周囲の腸間膜には播種性転移と思われる小結節を多数認めた。腫堭単独切 除俚不可能と判断し, 空腸を $40 \mathrm{~cm}$ 合併切除した. 平成 15 年 7 月 8 日, 化学療法目的にて当院 皮庸科転科となった。現在，当院皮拥科にて経過観察中である。

PPS-3-279 腹腔内リンパ節転移を契機に発見された空腸カルチノイ ドの一例

三谷泰之, 中谷佳弘, 谷 葚至, 川井 学, 山上裕機

(和歌山県立医科大学第 2 外科)

[症例] 症例は 85 歳, 男性. 腹部腫瘤触知を主訴に受診した. 腈の左上方に $3 \mathrm{~cm}$ 大の 可動性のある腫嘴を触知した. 腫堭は, CT で low density, 内部が不均一に造影され, MRI で low intensity で内部に筋肉と等信号の部分をもち, カラードップラーにて血流 豊富で径は $3.5 \mathrm{~cm}$ であった. 上部および下部消化管内視鏡では異常を認めなかった. 小 腸 GIST を考え手術を施行した. 回腸に径 $1.5 \mathrm{~cm}$ 大の槳膜に露出した病変と, 腸間膜内 に徍 $3.5 \mathrm{~cm}$ 大の腫場を認め, 腸間膜の毫縮を認めた. 腫瘍辺縁を切除ラインとして小晹 部分切除術を施行した. 病理組織診断はカルチノイドであった. 腫癔の進達度は se, 脈管侵襲を伴ったカルチノイドで，腸間膜腫湯は複数の転移リンパ節が一塊となった ものであった. 晹間膜に $5 \mathrm{~mm}$ 大の結節を認め, 腹膜転移单であった. 本症例は, 局所 再発, 遠隔転移の可能性が高く, CT で定期的に観察する必要があるが, 術後 2 ヶ月で 再発は認めていない.[まとめ] 原発巣よりも大きな転移りンパ節の触知が発見の契機 となった小腸原発カルチノイドを経験したので，文献的考察を加え報告する. 
PPS-3-280 サンドスタチンが有効であった回腸悪性カルチノイド腫 瘍の一例

古川潤二11, 鈴木慶一" ${ }^{1}$, 橋本健夫 ${ }^{11}$, 大野通暢 ${ }^{1}$, 勝又貴夫",

山崎 晋", 星 和栄 ${ }^{2 !}$

(国立杤木病院外科 ${ }^{1}$, 国立枋木病院病理 ${ }^{21}$ )

症列は, 61 歳男性. 平成 13 年 10 月に下腹部痛, 腰府のため他院に受診し, 腹部 CT 検查にて腹脄内腫瘍

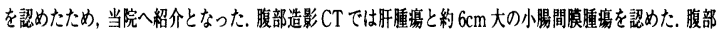

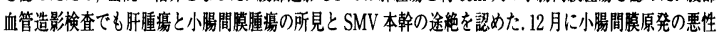
リンパ腫等の可能性を考え，手術を施行した，小腸間膜に的 $7 \mathrm{~cm}$ 大の腫鹪を諗め, SMA 及び SMV 本幹

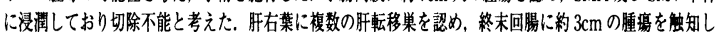
た. 小腸間膜隀堭の切除は断念したが回腸が循噮障害により将来的に狭窄をきたす可能性を考え，約 2

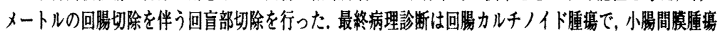
はリンパ節転移と診断された. 術後にサンドスタチン $100 \mu \mathrm{g}$ の皮下注射を連日施行した，小埸間膜りンパ

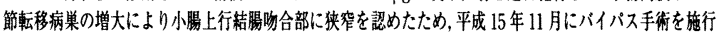
した. 初回手術的 2 年後の現在肝転移单はNCの状態であり，初回手術後とは㳗同等のQOLを保ててい る. 今回サンドスタチンが有効であった回晹悪性カルチノイド腫場の一例を経験したので報告する.

PPS-3-281 長期生存が得られている直腸癌術後小腸転移の一例 木村章彦, 竹内 勤, 皆木真一, 鈴木一則, 上田 毅 (鳥取生協病院外科)

小腸战は転移性が多く予後は不良である. 今回我々は直腸癌術後の瘾着性イレウスにて 再開腹時空腸に腫瘍病変を発見し局所切除を行ったが術後直腸症の小腸転移と診断さ れその後も長期生存が得られている症例を経験した. [症例] 61 嵅. 男性. 1997 年便柱狭 小, 下血をきたし直腸 S 状部癌と診断され手術を行った. 腫瘍は Rs を中心に局所浸潤 のため膀胱壁と小腸と後腹膜の一部を合併切除した. 病理診断では si, nl (+), ly2,v 0, stage IIIa, 高分化腺痵であった. 術後化学療法は low dose FP 療法を行い, 骨盤腔に $\mathrm{X}$ 線照射 40Gy を行った. 1998 年イレウスのため開腹手術を行った. 抎張した空腸に小 指頭大の硬結を触知し楔状局所切除した。イレウスに対しては回腸が骨盤峔で一塊と なっていたため空腸上行結腸側側吻合を行った. 小腸腫堭は乳頭状增殖を示す直腸癌の 転移と病理診断された，術後 6 年経過し再発兆候なく経過している.【考察】本例は原発 巣がly2, v0, si でありリンパ行性か腹膜播種性と考えられた．転移性小腸腫場の予後は 切除しても 6 12 ヶ月以内に大部分が死亡するとされているが, 本例のように偶然では あっても早期に発見され切除できれば長期生存が期待できると考えられた.

PPS-3-282 術後 3 年の経過で転移形式不明な腹壁再発を来した小腸 癌の 1 例

小林慎二郎, 大橋正樹, 天満信夫, 草野 央

(筑波胃腸病院外科)

症例は 64 歳, 男性. 2000 年 10 月小腸癌にて空腸部分切除術を施行, 病理所見で well differentiated tubuler adeno carcinoma (INF $\beta$, ly2, v2, se) であった. 術後外来にて UFT 経口投与を行っており経過良好であったが, 2003 年 10 月より右下腹部に鵎卵 大の腫瘤が出現した，超音波検査及び CT 検査にて同腫瘤は腹壁内の腫瑒と診断し

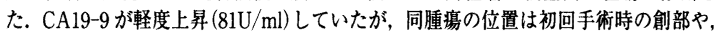
ドレーン挿入部と接していなかったため, 当初は小腸癌との関連性は低いものと考え られた. しかし腫湯が増大傾向を認めたため, 2004 年 1 月腫瘍摘出術を施行した. 腫 瘍は一部腹膜に露出していたが大部分は筋肉内に存在し, 腹腔内には明らかな腫教や 結節は認めなかった. 術後病理所見で筋肉を中心とする軟部組織内に well differentiated adeno carcinoma が認められ小腸癌の転移性腫瘍と診断した. 小腸癌は稀な疾患 である. 初回手術から 3 年の経過で他に明らかな転移, 再発が認められず, さらに転 移形式の明らかでない極めて稀な部位に再発した症例を経験したので報告する.

PPS-3-283 当院における原発性小腸腫瘍の臨床病理学的検討 伊藤 誉", 山崎高宏", 服部昌和 ", 林 裕之", 道伝研司",

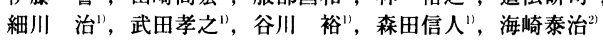
(福井県立病院外科 ${ }^{11}$, 福井県立病院病理研究科 ${ }^{21}$ )

1977 2003 年, 26 年間の当院における手術治療を行なった原発性小腸悪性腫瘍を臨床 病理学的に検討したので報告する，原発性悪性腫場の組織型頻度は，悪性リンパ腫 17 例, 癌 7 例, 平滑䇨肉腫 7 例, 回腸平滑筋芽細胞腫 1 例, 覀性 GIST1 例であった, 男 女比は全体で $1.4: 1$ と男性に多く, 組織型別には悪性リンパ腫, 澏は男性に多く, 平 滑筋腫は女性に多かった，年龄別頻度では悪性腫瘍全体では 40 歳台から 70 歳台が高 頻度で, 全体の $94.0 \%$, 特に 50 藏台と 60 歳台で全体の $70.0 \%$ を占めていた. 臨床症状 では, 腹痛 $(69.6 \%)$, 腸重積 $(12.0 \%)$, 腹部膨満感 $(12 \%)$, 急血 $(9.0 \%)$, 下血 $(8.4 \%)$, 穿孔 $(6.0 \%)$, 腹部腫瘤 $(6.0 \%)$ の順に多かった. 悪性リンバ腫では， $23.5 \%$ に腸重積，

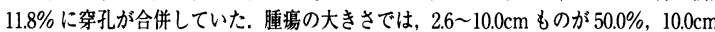
以上の腫瘍は $47.0 \%$ を占めた. $2.5 \mathrm{~cm}$ 以下の腫場は $3.0 \%$ にすぎなかった. 今回の検討

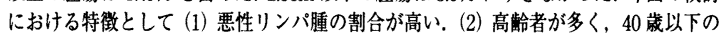
若年層が少ない.（3）腫瘍の大きさが $10.0 \mathrm{~cm}$ を超えるものが多い傾向があった.
PPS-3-284 胆管空腸吻合術後 8 年Hに吻合部から出血した 1 例

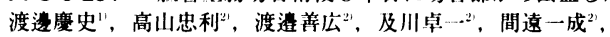

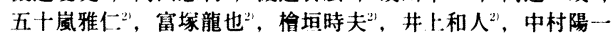

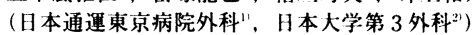

胆道系と空腸の吻合術後に肝外門脈閉寒をきたした場合, 遠隔期合併症とし て，挙上空腸からの出血に注意すべきである．胆管空腸吻合術後，下血を主 訴に来院し，出血部位の同定および治療に難涉した症例を経験した. 【症 例】症例は 53 歳男性. 8 年前慢性羘炎による閉寨性黄㾝のため, Roux-Y 再建による胆管空腸吻合術を行ったが， 3 年後に下血し，血管造影で門脈本 幹の閉塞と発達した側副血行が認められた。門脈造影で胆管空腸吻合部付近 の空腸からの出血を認め, 経回結腸静脈門脤塞栓術(TIPE)により止血した. 今回 $(8$ 年後) 再度の下血のため, TIPE, 動脈塞栓術 (TAE)により塞栓術 を行ったが、第 3 病日に再び下血したため,開腹手術を行った. 空腸空腸吻 合部肘門側から胆道ファイバーを挿入したところ、胆管空腸吻合部からやや 肛門側の露出血管からの出血を認めたため，胆管空腸吻合部近傍を切開し， 直視下に結紮止血した。術後 1 年経過したが, 再出血を認めていない.

PPS-3-285 短腸症候群残存腸管に対する GLP-2, GH, KGF 順応修飾 効果の比較検討

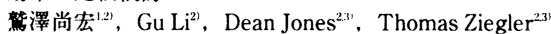

(東邦大学医学部一般消化器外科学 (大森) 講座", Emory 大学内科 ${ }^{2}, \mathrm{Em}$ ory 大学臨床分子栄養学3")

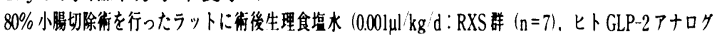

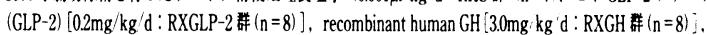

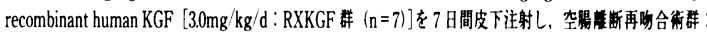

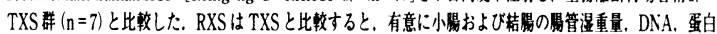

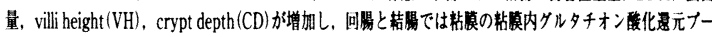

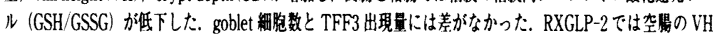
$と$ total mucosal height (TMH) が他の群と比䖝して有意に增加し. RXGH とRXKGF ては RXS と比較して

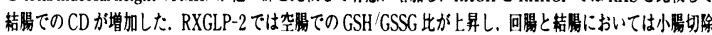

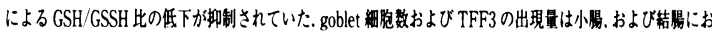

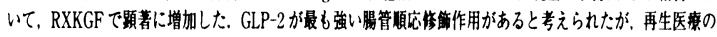

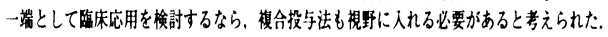

PPS-3-286 術後長期間経過して発症した Blind loop syndrome (BLS) の 2 治験例

笹屋高大", 早川直和”，山本英大"

高良大介", 梛野正人 ${ }^{21}$, “村雄次"

(東海病院外科", 名古屋大学大学院器官調節外科 ${ }^{21}$ )

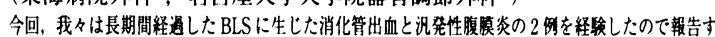

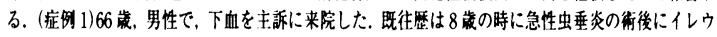

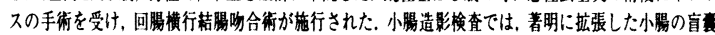
が造影され，大腸内梘鏡検查では明らかな出血源は磼認できなかった，以上り移50年前のイレウ

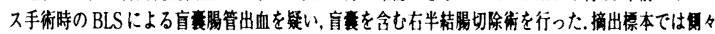

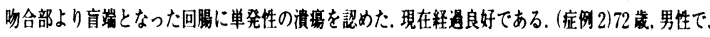
腹痡を主新に来院した，既往歴は䄪60年前に急性虫垂炎術俊に腹偾炎となったため再手術を受けて

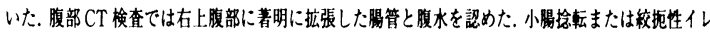

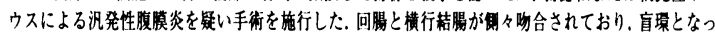
た回腸が搪張し捻転していた，明らかな穿孔部位もなく，全身状態し不良なことから洗净ドレナージ

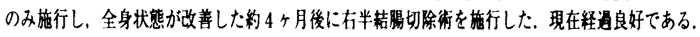

PPS-3-287 下血を契機に見つかった小腸 gastrointestinal stromal tumor の一例

品川裕治, 古平千津, 沖野秀宣, 松本伸二, 島田和生, 廣吉元正, 河野竜二, 鬼塚幸治, 岩村道㶳, 高浪英樹

(国立小会病院消化器病センター外科)

小晹原発 Gastrointestinal stromal tumor (以下 GIST) は症状が出にくく，径が大きくなって から診断がつくことも多い，今回われわれは，消化管出血の原因検索で見つかった直径 $2 \mathrm{~cm}$ の小腸 GIST を経験したので報告する.症例は 34 才女性. 当院受診の1年 3 ケ月前に黑色便と 意境消失発作を認め，精査を施行されたが診断はつかなかつた，平成 15 年 2 月に同様の症状 を認め当院紹介人院となった，上部消化管及び大晹内視鏡検査，小腸透視，CT 検査などでは 診断がつかず，血管造影で空腸動腺に early venous refilling を伴う nidus 梯腫葪陰影を認め た. 直徍 $2 \mathrm{~cm}$ と小さかったが出血を綵り返したと思われ，腹脄镜を補助的に用い，空腸部分切

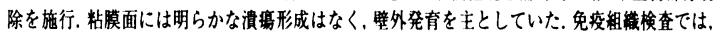

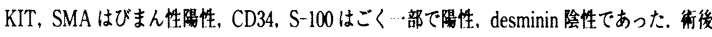
経過は順調で，現在まで再発は認めていない，覀性GISTに対し imatinibが近年導入された

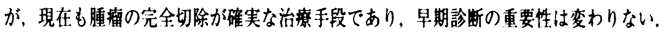

